\title{
- TIME FOR ACTION
}

CHANGING THE GENDER SITUATION IN FORESTRY

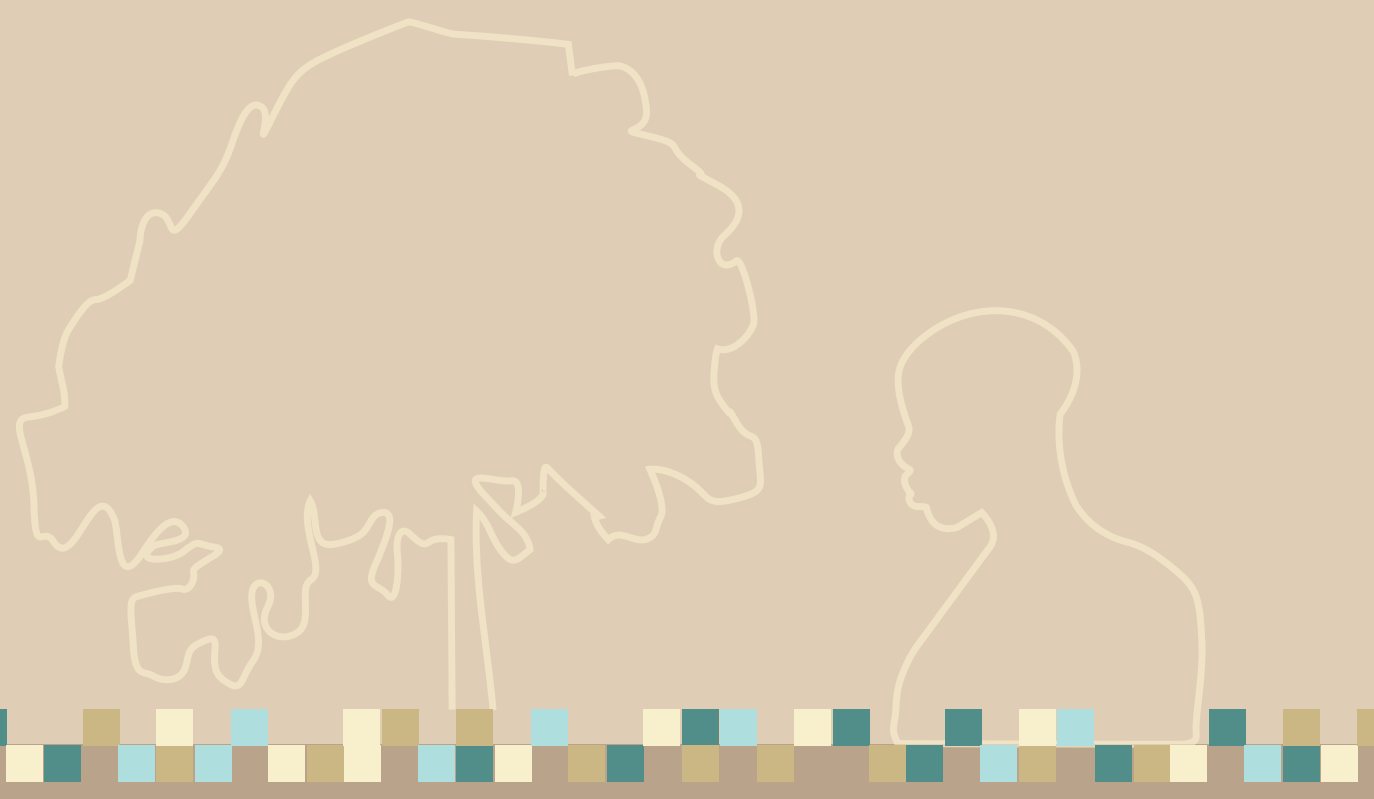





\section{1.- Time for action Changing the gender situation in forestry}

Report of the team of specialists on gender and forestry 
The designations employed and the presentation of material in this information product do not imply the expression of any opinion whatsoever on the part of the Food and Agriculture Organization of the United Nations concerning the legal or development status of any country, territory, city or area or of its authorities, or concerning the delimitation of its frontiers or boundaries.

All rights reserved. Reproduction and dissemination of material in this information product for educational or other non-commercial purposes are authorized without any prior written permission from the copyright holders provided the source is fully acknowledged. Reproduction of material in this information product for resale or other commercial purposes is prohibited without written permission of the copyright holders. Applications for such permission should be addressed to the Chief, Publishing Management Service, Information Division, FAO, Viale delle Terme di Caracalla, 00100 Rome, Italy or by e-mail to copyright@fao.org

(C) FAO 2006 


\section{FOREWORD}

The Team of Specialists on 'Gender and Forestry' was established in April 2004 by a decision of the former FAO/ECE/ILO Joint Committee on Forest Technology, Management and Training. The objective was to raise visibility of women and women's involvement in the forestry sector and to understand the gender structures throughout the sector. The Team's mandate was developed from discussions and recommendations at the FAO/ECE/ILO seminar in Viseu, Portugal in 2001, and has been regarded as part of a strategic framework for the work carried out by the Team during the two years period. The Team focussed on reviewing relevant and available data, which is compiled and presented in this Final Report.

The Team was made up of 15 specialists from across Europe and North America, and the work has mainly been carried out by team members.

I would like to thank the Team for their contribution and goodwill, and for committing themselves on top of normal duties to execute the manadate given by the former joint committee. In particular, I thank the Team coordinators Anna Springfors and Simmoné Rose, the editors Renate Späeth, Marion Karman and Maria Gianinni and the lay-out artist Maria Guardia. In addition to Team members' work, very valuable contributions have been made by a number of other persons; Inna Hakobjanyan, Mike Fullerton, Željka Ivanović, Marilena Idžojtić, Katja Turunen, Ritva Toivonen, Laura Secco, Laura Peruch, Viera Petrasova, Zusana Sarvasova Lea Jylha, Diana Mizaraite, Uta Hohn, Andreas Keil, Orhan Güles, Mulualem Tigabu, Robert Nygård, Margareta Söderberg Maria Hehn and Till Westermayer. I would like to thank them all for their efforts which have enriched this Final Report.

However, the work on this important subject is not finished, indeed scarcely begun. I hope that what we have done will not only raise awareness, but also lead to actions for a better gender balance in forestry.

\section{Gun Lidestav}

Team Leader 



\section{CONTENTS}

$\begin{array}{ll}\text { FOREWORD } & \text { iii }\end{array}$

Introduction 1

Background 1

1 Gender structures in forestry organizations $\quad 7$

$\begin{array}{ll}1.1 \text { Introduction } & 7\end{array}$

1.2 Review of the current situation $\quad 8$

1.2.1 What is the current status quo of gender representation across organizations?

1.2.2 Why is gender representation as it is? 12

1.2.3 What are the key drivers for change and the actions required in driving the employment gender "agenda" forward? 13

1.2.4 What are the positive benefits to be gained? 15

1. 3 Employment Trends - The European Forest Sector Outlook Study 16

1.4 Armenia 17

$\begin{array}{ll}\text { 1.4.1 Introduction: } & 17\end{array}$

1.4.2 Socio-demographic situation in Armenia, including gender issues 17

1.4.3 Gender structure in Armenian forestry 18

1.4.4 Employment at other Armenian forestry agencies $\quad 18$

$\begin{array}{lr}\text { 1.4.5 Conclusions } & 20 \\ 1.5 \text { Canada } & 20\end{array}$

$\begin{array}{lr}1.5 \text { Canada } & 20\end{array}$

1.5.1 The Employment Equity Framework in Canada 20

$\begin{array}{ll}\text { 1.5.2 Gender-based analysis } & 21\end{array}$

1.5.3 Gender issues in Natural Resources Canada and the Canadian forest service 22

$\begin{array}{ll}\text { 1.5.4 Gender statistics for the Canadian forest sector } & 24\end{array}$

$\begin{array}{ll}\text { 1.5.5 Gender demographics of Canadian university graduates } & 24\end{array}$

\begin{tabular}{lr} 
1.5.6 Conclusion & 25 \\
\hline
\end{tabular}

$\begin{array}{lr}\text { 1. } 6 \text { Croatia } & 26\end{array}$

$\begin{array}{lr}\text { 1.6.1 Summary } & 26\end{array}$

$\begin{array}{lr}\text { 1.6.2 Introduction } & 27\end{array}$

$\begin{array}{lr}\text { 1.6.3 Methodology } & 28\end{array}$

$\begin{array}{lr}1.6 .4 \text { Results } & 28\end{array}$

$\begin{array}{lr}\text { 1.6.5 Conclusions } & 29\end{array}$

$\begin{array}{lr}1.7 \text { Finland } & 29\end{array}$

$\begin{array}{lr}\text { 1.7.1 Background } & 29\end{array}$

$\begin{array}{lr}\text { 1.7.2 Data } & 30\end{array}$

$\begin{array}{lr}1.7 .3 \text { Results } & 30\end{array}$

1.7.4 Activities to develop women foresters' careers in Finland 32

$\begin{array}{ll}1.7 .5 \text { Conclusions } & 33\end{array}$

$\begin{array}{ll}1.8 \text { Germany } & 33\end{array}$

1.8.1 The current status of gender representations across organizations in Germany 34

1.8.2 Why is the gender representation the way it is in Germany's forestry sector? 38

$\begin{array}{ll}1.9 \text { Italy } & 39\end{array}$

$\begin{array}{lr}\text { 1.9.1 Introduction } & 40\end{array}$

1.9.2 Official data on women in the primary sector in Italy 40

1.9.3 Results of a preliminary ad hoc survey in Italy $\quad 47$

1.9.4 Final considerations for Italy $\quad 49$

$\begin{array}{ll}1.10 \text { Norway } & 50\end{array}$

1.10.1 General aspects of the forestry sector in Norway $\quad 50$

1.10.2 Gender representation across organizations in Norway $\quad 50$

1.10.3 Gender structure within forestry education $\quad 53$

1.10.4 Gender representation in Norway $\quad 55$

1.10.5 What are the key drivers for changing the gender "agenda" forward in Norway? 56 
1.10.6 What are the positive benefits Norway can gain?

1.11 Poland $\quad 58$

1.11.1 Background $\quad 59$

1.11.2 General characteristics of Poland's forests and forestry 60

1.11.3 Gender in forest ownership 61

1.11.4 Employment in Poland and the forestry sector 63

1.11.5 Women in science $\quad 65$

1.11.6 Conclusion $\quad 65$

1.12 Slovakia $\quad 66$

1.12.1 Introduction $\quad 66$

1.12.2 Women's situation in Slovakia 66

$\begin{array}{ll}1.12 .3 \text { Educational level of female foresters } & 67\end{array}$

$\begin{array}{ll}1.12 .4 \text { Conclusion } & 68\end{array}$

1.13 Sweden $\quad 69$

1.13.1 Swedish Forestry in general 69

1.13.2 The current status quo of gender representations across organizations in Sweden 69

1.13.3. Why is gender representation the way it is?

1.14 United Kingdom $\quad 73$

1.14.1 Employment of women in UK forestry industry 73

1.14.2 What are the reasons for this picture? $\quad 76$

1.14.3 What can be done to address the imbalance? $\quad 78$

1.15 The United States

1.15.1 The United States Forest Service Agency 79

1.15.2 The Forest Service administrative units $\quad 79$

$\begin{array}{ll}\text { 1.15.3 Workforce objectives } & 79\end{array}$

1.15.4 Gender history $\quad 80$

1.15.5 CLF comparisons with women in the Forest Service 80

1.15.6 Forest Service leadership positions $\quad 82$

1.15.7 Leadership at national headquarters $\quad 82$

1.15.8 Leadership across the United States $\quad 82$

1.15.9 Women in key leadership positions

1.16 Review of gender situation in other countries 83

1.17 Summary $\quad 86$

2 Gender structures in family forestry $\quad 89$

2.1 Introduction $\quad 89$

2.1.1 Ownership structure in the ECE area

2.1.2 Lack of data 90

2.2 Gender structures in Swedish family forestry 90

2.2.1 Introduction $\quad 90$

2.2.2 Gender and inheritance in Swedish family forestry 90

2.2.3 Comparing male and female owners 93

2.2.4 Women's representation in forest owners' associations 95

2.3 Nordrhein-Westfalen, Germany 96

2.3.1 Introduction 96

2.3.2 Survey concerning forest owners' structure and motivation 96

2.3.3 Conclusions 96

$\begin{array}{ll}2.4 \text { Norway } & 97\end{array}$

2.4.1 Introduction $\quad 97$

2.4.2 Gender structure in the Norwegian Forestry Association 97

2.4.3 Gender structure in the Norwegian Forest Owners' Federation 98

2.5 Gender structures in Finnish family forestry 104

2.5.1 The Finnish ownership structure 104

2.5.2 The MTK $\quad 105$

2.5.3 Gender structure at the national level $\quad 105$

2.5.4 The Regional level 105 
2.5.5 MTK's equality programme

2.6 Gender structures in Baltic family forestry 106

2.6.1 General aspects of the forestry sector in the Baltic States 106

2.6.2 Private management problems and the needs of the private forest owners 107

$\begin{array}{ll}2.6 .3 \text { Conclusions } & 109\end{array}$

2.7 Summary and conclusions 109

3. Gender and perceptions of forest and forestry 111

3.1 Perceptions of forests and forestry - what people think about forests and forestry 111

3.2 The public's perception of and relation to the forest or how Swedish men and women
view the forest

3.3 Innovation and Forestry: Attracting visitors and changing perceptions $\quad 115$

3.3.1 Borders Forest Trust Projects: 116

3.3.2 The importance of initiatives like BFT in the United Kingdom 118

3.3.3 Future Research on changing perceptions about forestry 118

3.4 Urban nature - perception, evaluation and adoption by Turkish migrants in the
northern Ruhr area under special consideration of urban-industrial woodlands

$\begin{array}{ll}3.4 .1 \text { Research design } & 119\end{array}$

3.4.2 Interview of the residents 119

3.4.3 Expert interviews $\quad 120$

$\begin{array}{ll}3.4 .4 \text { Conclusion } & 120\end{array}$

3.4.5 Summary $\quad 122$

4. Means and actions $\quad 123$

4.1 Introduction $\quad 123$

4.2 Political tools $\quad 123$

4.2.1 Sweden 123

4.2.2 Political tools in Norway $\quad 126$

4.2.3 The United States Civilian Labor Force 128

4.2.4 The gender mainstreaming strategy within the European Union $\quad 128$

4.3 Gender issues in education and research: cases and examples 134

4.3.1 Introduction 134

4.3.2 Do gender-related factors influence students' choice of courses at the Faculty of
Forest Sciences, SLU, Umeå?

4.3.3 Gender issues in forestry curricula - results from surveys in 2002 and $2004 \quad 136$

4.3.4 Gender studies - a new subject in forestry curricula: the University of Freiburg, Germany 139

4.3.5 Gender does matter: studying corporate culture and the possibilities for gender-sensitive
reforms in Germany's forest services

4.4 Networks on women and forestry 146

$\begin{array}{ll}\text { 4.4.1 Networks in Sweden } & 147\end{array}$

$\begin{array}{ll}\text { 4.4.2 Slovakia } & 148\end{array}$

$\begin{array}{ll}\text { 4.4.3 Lithuanina } & 149\end{array}$

4.4.4 Networks in Germany 150

4.4.5 The Norwegian organization - Women in Forestry 152

5. Criteria and indicators $\quad 155$

6. Summary and conclusions $\quad 157$

REFERENCES $\quad 163$

$\begin{array}{ll}\text { ANNEXES } & 173\end{array}$

I. List of acronyms and definitions: 173

$\begin{array}{ll}\text { II. List of Tables } & 174\end{array}$

III. List of Figures $\quad 176$

IV. List of ToS members $\quad 177$

$\begin{array}{ll}\text { V. Norway: Political tools } & 178\end{array}$

VI. Norway: Actions carried out by Women in Forestry 181

$\begin{array}{ll}\text { VII. References to endnotes for Questions } 4 \text { to } 7 & 185\end{array}$ 



\section{INTRODUCTION}

\section{BACKGROUND}

Human societies are deeply pervaded by the principle of gender, by which individuals, animals and inanimate objects and things are sorted and assigned a value. Throughout history, most phenomena have been given a masculine or feminine connotation.

Ideas of specific masculine or feminine qualities are thus connected to certain roles, positions, tasks and professions in individuals. The perception of what is "appropriate" for men and women forms the basis for the distribution of work, the design and the evaluation of different tasks, and the criteria for promotions. Forestry is not an exception to this since it has been generally regarded as an arena mainly for men's work, business and governance. Within organizations, from households to companies to authorities, a gendered organizational logic is at work, which not only reproduces a structure of gender division but also, paradoxically, at the same time, makes gender invisible.

Gender invisibility comes in many forms. One example is the way in which the terms forestry and forestry work are defined and perceived, while another is the way statistics on the involvement of women and men in the forestry sector are not kept separate, or not at all. In many countries, reliable statistics on the demographics of the forestry workforce are difficult to obtain, and when it concerns women's participation, data are virtually non-existent. Similarly, information on women's involvement in family forestry, both as part of the workforce and as owners, is also scarce.

Therefore, in April 2004, the Joint FAO/ECE/ILO Committee on Forest Technology, Management and Training established a Team of Specialists (ToS) to study gender and forestry in order to raise visibility of women and women's involvement in the forestry sector and to understand the gender structures throughout the sector. The ToS was an outcome of the seminar on 'Women in Forestry - Strategies to Increase Women's Participation in the Forestry Sector in Europe and North America", which was held in Viseu, Portugal, in April 2001. The Joint Committee agreed that they would play an active role in advocacy and remind countries of their obligation to promote equal opportunity between men and women, which is in direct alignment with one of the goals of the United Nations Women's Conference held in Beijing, China, in 1995. The countries who attended the conference agreed to adopt and implement gender mainstreaming as a strategy for involving and integrating gender equality into all major policy and decision-making processes. Adopting such a strategy 
ensures that gender considerations will permeate all aspects and areas of governmental policy. Increasingly, a number of influential drivers have been effecting change on global, regional and national levels: at the United Nations level (the women's conference in Beijing, for instance) to the European Union Agricultural Council action plans (2004) regarding gender mainstreaming and country-level legislative changes and government policy initiatives.

\section{MANDATE AND MEMBERS OF THE TEAM OF SPECIALISTS}

The ToS members were selected either directly by the Joint Committee secretariat or through a nomination process by their respective countries. The nomination process resulted in the following Team:

Liz Agpaoa (United States) is Chief of Staff for the United States Forest Service. She has worked in the natural resources field for more than 25 years, providing leadership as district ranger and forest supervisor. She has been involved in the area of civil rights and diversity, including gender diversity, throughout her career in the Forest Service. Currently she serves on a non-governmental board for the diverse selection of graduate candidates for scholarship recommendation.

Skadrite Albertina (Latvia) holds an undergraduate degree in forestry and a Ph.D. in biology. She is a member of the Forest Owners' Association of Latvia, a board member of the Forest Owners Association of Latvia and chairperson of the Council of PEFC, Latvia. From 1968 to 1977, she was lecturer of forestry and silviculture. Her project experience includes education and training in forest, private forestry strengthening in Latvia, rural development programme of Latvia, rural diversification in Latvia, forest certification, models, systems, implementation of PEFC system in Latvia.

Merete Furuberg (Norway - International Union of Forest Research Organizations [IUFRO]) has a Ph.D. in forest engineering. She is forest owner, researcher, politician and among one of the women that established the organization "Women in Forestry" in Norway. She initiated the first World Wide Symposium on Women and Forestry in Lillehammer, Norway, 1999. One outcome was the new research group within IUFRO on "Gender and Forestry", where she is coordinator. Gender perspective and issues have been a topic for several years in her work. She is an Assistant Professor at the Hedmark University College, Norway.

Natalie Hufnagl (Germany - Confederation of European Forest Owners [CEPF]) is SecretaryGeneral of the CEPF since 1999. In this function, she coordinates the policy input of national forest owners' associations from 23 European countries to European and global forest policy institutions and processes. She is a member of the "Women in Natural Resource Management" network that was founded in 2003.

Marion Karmann (Germany) has a Ph.D. in natural science/forest work science. She is a visiting lecturer 
and former researcher in work science at the University of Freiburg. The view on gender issues in forestry has been a focus in her research on national and tropical forest utilization and ergonomics as well as in her work with forest labour unions and as IUFRO office holder. She is presently coordinator at the Forest Stewardship International (FSC).

Bozena Kornatowska (Poland - Ministerial Conference on the Protection of Forests in Europe [MCPEF]) has a Ph.D. in Agricultural Sciences at the Agricultural University in Warsaw, Poland. She has worked on several scientific projects concerning forestry and agriculture, with special emphasis on crop protection, at the Forest Research Institute, Warsaw, Poland; the University of Pennsylvania, Philadelphia, United States; and the University of Guelph, Guelph, Canada. For the past two years, she has worked for the MCPFE Liaison Unit, Warsaw, as a specialist on communication and organization.

Siegfried Lewark (Germany) is professor of forest work science at the University of Freiburg. In teaching and research, he has been dealing with gender issues for more than ten years. He helped found the IUFRO unit on Gender and Forestry, and is coordinator of the IUFRO unit on Education, Gender and Forestry.

Gun Lidestav (Sweden) is associate professor at the Department of Resource Management and Geomatics, Swedish University of Agricultural Sciences. In her research on family forestry and contract labour force in the entire forestry sector, gender perspective and gender issues have been a main topic for several years. She has also developed postgraduate courses on this topic.

Wieslawa L. Nowacka (Poland) is adjunct professor at the Department of Forest Utilization, Warsaw Agricultural University (SGGW). Her research has focused on ergonomics applied to forestry with particular emphasis to physiology of work, the situation of women in forestry, and family life of those living near forests and use of forest products. She steered several master theses regarding women in forestry.

Simmone Rose (Food and Agriculture Organization of the United Nations [FAO]) is a Forestry Officer with the Forest Products and Economics Division. She is responsible for Post Harvest Impact Assessments and is one of the gender focal points for the Forestry Department.

Anna Springfors (Food and Agriculture Organization of the United Nations [FAO]) is a former Associate Professional Officer attached to the FAO Forestry Department. While at FAO, she was involved in work on microfinance and gender issues.

Berit Sanness (Norway) was the first chairperson of Women in Forestry (1986-1992) and the former Director of Information and Director of International Affairs at the Norwegian Forest Owners' Federation. She managed the Living Forests project (the stakeholder process in Norway) in the 1990s and played a key 
role in the establishment of PEFC (global forest certification system). Presently, she manages the consultant company Pinus-Betula AS.

Renate Spaeth (Germany) is forest officer at the Ministry for Environment in Nordrhein-Westfalen. She has been working on different aspects of forestry such as forest policy, planning, nature conservation, environmental education and public relations. She is a member of the German Network "Frauen in der Forstwirtschaft", initiated a regional network of female forest owners and is internationally active for women in forestry.

Patricia Tomlin (United Kingdom) is director of the management consultancy company Wildcat One Ltd. She undertook the first substantive research on the employment of professional women foresters in the British forestry industry, on behalf of the British Forestry Commission in 2000, and presented findings from this research at the FAO/ECE/ILO seminar in Viseu, Portugal, in 2001. She works regularly with clients in the field of equal opportunities, diversity and managing change.

Gunilla Törnquist-Hedström (Sweden) is forest owner and member of the Swedish women forest owners' association Black Woodpecker. She represents the forestry sector in a reference group supporting the Minister of Agriculture in Sweden. At present, she is a senior adviser and communications consultant.

Eriks Zakis (Latvia) is a member of the Latvian Forest Owners' Association.

At the first workshop held in Rome on 23 April 2004, Gun Lidestav was elected Team Leader, Skadrite Albertina as Deputy Team Leader, and Simmone Rose and Anna Springfors contributed as coordinators.

The Team of Specialists' mandate was developed from discussions and recommendations at the FAO/ ECE/ILO seminar in Viseu, Portugal (2001), and should be regarded as a strategic framework rather than a targeted one. The mandate covers:

- reviewing relevant data;

- developing criteria and indicators that reflect gender aspects in sustainable forest management;

- launching case studies concerning specific aspects of gender and forestry, including family-owned forests;

- disseminating information about national experiences, in particular success measures and good practices;

- promoting national networks of women in forestry; and

- organizing follow-up meetings to the 2001 seminar in Portugal that focus on "Gender in Forestry" and used to monitor change in gender balance and equal opportunity. 
The Team of Specialist has focused its work mainly on the first and last issue, but it has also concentrated on disseminating information on national experience and organizing meetings. So far, five meetings have been held since the seminar in Portugal (see Table 1).

\section{At the first meeting, three subthemes and subgroups were set up, namely:}

(i) gender structures in forestry organizations;

(ii) gender structures in forest ownership; and

(iii) gender and the perceptions of forests and forestry.

This report continues to follow the same subtheme structure for reviewing the current forestry situation. Because country data was difficult to find or retrieve, the ToS decided to use a case study approach and presented cases from areas where reliable and abundant data was available.

Moreover, Chapter 4 explores the different means and actions for improving gender balance in the forestry sector while Chapter 5 outlines the recommendations for criteria and indicators on gender in forestry. Finally, Chapter 6 presents the conclusions and recommendations.

Table 1: FAO/ECE/ILO Team of Specialists Attendance at Meetings on Gender and Forestry

\begin{tabular}{|c|c|c|c|c|}
\hline $\begin{array}{l}\text { Rome, Italy } \\
23 \text { April } 2004\end{array}$ & $\begin{array}{l}\text { Düsseldorf, Germany } \\
\text { 22-23 November } 2004\end{array}$ & $\begin{array}{l}\text { Zvolen, Slovakia } \\
\text { 18-19 June } 2005\end{array}$ & $\begin{array}{c}\text { Piedmont, Italy } \\
\text { 28-29 October } 2005\end{array}$ & $\begin{array}{c}\text { Rome, Italy } \\
\text { 30-31 March } 2006\end{array}$ \\
\hline Merete Furuberg & Liz Agpaoa & Liz Agpaoa & Liz Agpaoa & Liz Agpaoa \\
\hline Natalie Hufnagel & Merete Furuberg & Merete Furuberg & Marion Karmann & Merete Furuberg \\
\hline Marion Karmann & Marion Karmann & Bozena Kornatowska & Siegfried Lewark & Natalie Hufnagel \\
\hline Siegfried Lewark & Bozena Kornatowska & Siegfried Lewark & Gun Lidestav & Bozena Kornatowska \\
\hline Gun Lidestav & Siegfried Lewark & Gun Lidestav & Simmone Rose & Siegfried Lewark \\
\hline Berit Sanness & Gun Lidestav & Simmone Rose & Berit Sanness & Gun Lidestav \\
\hline Renate Spaeth & Wieslawa Nowacka & Berit Sanness & Renate Spaeth & Simmone Rose \\
\hline Anna Springfors & Berit Sanness & Renate Spaeth & & Berit Sanness \\
\hline Patricia Tomlin & Renate Spaeth & Gunilla Tornqvist & & Renate Spaeth \\
\hline Gunilla Tornqvist & Anna Springfors & & & Patricia Tomlin \\
\hline Eriks Zakis & Patricia Tomlin & & & Gunilla Tornqvist \\
\hline
\end{tabular}





\section{GENDER STRUCTURES IN FORESTRY ORGANIZATIONS}

\subsection{INTRODUCTION}

In order to assess the current situation pertaining to gender structures of employment and work in forestry organizations it was important for the team to determine the scope of the study. The team agreed that the overall review needed to encompass the whole forestry supply chain, including the forest and timber industries and arboriculture, as well as all sectors (i.e. the private and public sector, NGOs, cooperatives, universities, etc.). The study therefore has focused on direct employment relationships because more data was available in this area; however, indirectly, the intent was also to glean information about contract labour forces whenever possible.

The team identified four key areas to review:

(i) to determine the current status quo of gender representation, across the supply chain and across all sectors, drawing on existing quantitative and qualitative data, as well as to highlight critical data gaps;

(ii) to understand why gender representation is the way it is and whether this differs across different sectors and different geographical regions and countries;

(iii) to identify the key drivers for change and the means for driving the gender "agenda" forward; and

(iv) to confirm the positive benefits organizations could gain by applying new measures.

In attempting to answer the foregoing issues and establish a current picture of employment patterns for the industry, the ToS decided on studying the source materials from European and North American countries. The information includes:

- Statistical data (such as national census, workforce demographics and national industry-level data), the registries and records of trade organizations and professional memberships, and university/ college documents, etc.

- Qualitative research, including case studies, surveys, anecdotal evidence, among other things.

Each member of the group was assigned responsibility for collecting and reviewing data from different geographical regions, which was then collated centrally to provide an overview of the situation. 


\subsection{REVIEW OF THE CURRENT SITUATION}

\subsubsection{What is the current status quo of gender representation across organizations?}

One of the major challenges encountered during the course of this review was the relatively limited amount of data on gender and related issues. This was apparent across all aspects of the industry's supply chain (although less so for government and public sector organizations and, in some countries, larger NGOs). In some countries, for example Germany, the United Kingdom and the United States, national-level statistics for forestry are often encompassed with other land-based industries, making it difficult to determine the forestry industry's status. Similarly, the definition of what constitutes forestry work, as used at the national workforce census level, can sometimes differ from the one the industry uses.

These constraints prevented extrapolation of the data in a wider sense, or the ability to draw sufficiently robust conclusions on gender structures across the various sectors of the industry. It also proved difficult to undertake meaningful benchmarking across various sectors of the industry or of the different participant countries.

In view of the nature of data available and the evident gaps, a summary of data has been compiled, which helps to identify main, high-level themes. This, along with the broad criteria used for analysis, is detailed in Table 2.

\section{Explanation of Table 2:}

Q1. Question/Indicator: The economical impact of forestry/forest industry on society:

$$
(\mathrm{N})=\text { none } \bullet(\mathrm{L})=\text { little } \bullet(\mathrm{M})=\text { medium } \bullet(\mathrm{G})=\text { great } .
$$

For the economical impact classification of GDP, within the forest sector as percentage of total value, is used and set to three classes, made on the basis that characterizes some important forestry countries:

$$
(\mathbf{G}) \text { reat }>3 \% \bullet \quad(\mathbf{M}) \text { edium } 1-3 \% \quad \bullet \quad(\mathbf{L}) \text { ittle } 0-0.9 \%
$$

Q2. Question/Indicator: The cultural impact of forestry/forest industry on society:

$$
(\mathrm{N})=\text { none } \bullet(\mathrm{L})=\text { little } \bullet(\mathrm{M})=\text { medium } \bullet \quad(\mathrm{G})=\text { great }
$$

For the culture impact of forestry/forestry industry on society, three factors are taken together: forest area/capita, percentage of employment within forestry sector, and private ownership of forest area. Each factor is first estimated separately with three classes, then added together and divided by 3 . Results are given in three classes: 
$(\mathrm{N})=$ none $\bullet(\mathrm{L})=$ little $\bullet(\mathrm{M})=$ medium $\bullet(\mathrm{G})=$ great.

Forest area/capita (ha/cap): $\quad 3>1, \quad 2=0.5-1, \quad \mathbf{1}=0-0.49$

Percentage of employment within forestry sector: $\quad 3 \geq 2 \%, \quad 2=1-1,9 \%, \quad 1<1 \%$

Private forest area of total forest area: $\quad 3>50 \%, \quad 2=25-49 \% \quad 3<25 \%$

Sum of factors: $(\mathbf{G})$ reat $\geq 2$ (M)edium 1,5-1,9 (L)ittle $\quad<1,5$

Q3. Question/Indicator: Is gender/equality an issue in general in society?

Indicated by policy of gender mainstreaming, Equality Act or some other policies: $(\mathrm{Y})=$ yes, $(\mathrm{N})=$ no

Q4. Question/Indicator: Is gender/equality recognized as an issue in forestry/forest industry? $(\mathrm{Y})=$ yes, $(\mathrm{N})=$ no

Q5. Question/Indicator: If yes, what kind of actions (indicators) are there:

A) Some kind of official reports/studies/recommendations

B) Networks/organizations of, for example, female foresters or forest owners

C) Statistics divided by gender,

D) Research on gender and forestry

E) Programs in order to reach certain aims such as recruitment activities

\section{Q6. Question/Indicator: Are women's representation in forestry}

$\mathrm{B}$ (alanced) or $\mathrm{UnB}$ (alanced) considering (a) different levels/positions. (b) different parts of the forestry sector.

Q7. Question/Indicator: Is there any analysis of remuneration, careers, job satisfaction, etc.? $(\mathrm{Y})=$ yes, $(\mathrm{N})=$ no

If so, what did they show? 
Table 2: Gender situation and structures in forest organizations at the national level

\begin{tabular}{|c|c|c|c|c|c|c|c|c|c|}
\hline Country/ & & & & & & & & & \\
\hline Question & Q1 & Q2 & Q3 & Q4 & Q5 & Q6-A & Q6-B & Q7 & \\
\hline$\overline{\text { Armenia }}$ & $\mathrm{L}$ & - & & & & & & & \\
\hline Austria & $\mathrm{M}$ & G & Y-1 & & $\mathrm{A}$ & UnB & $\mathrm{UnB}$ & Y-8 & $\begin{array}{l}\text { Relative to health, } \\
\text { especially physical }\end{array}$ \\
\hline Belgium & - & $\mathrm{L}$ & Y-1 & & & & & & \\
\hline Bulgaria & $\mathrm{L}$ & $\mathrm{L}$ & & Y- & $\mathrm{A}$ & $\mathrm{B}$ ? & UnB & & \\
\hline $\begin{array}{l}\text { Bosnia and } \\
\text { Herzegovina }\end{array}$ & $\mathrm{M}$ & & & & A & & & & \\
\hline Canada & G & G & Y-3 & Yes & $\begin{array}{c}\text { A, B C-6 D- } \\
17,18\end{array}$ & UnB & UnB & $\mathrm{Y}$ & \\
\hline Croatia & $\mathrm{M}$ & $\mathrm{M}$ & $\mathrm{Y}$ & & A & $\mathrm{UnB}$ & $\mathrm{UnB}$ & Y-8 & $\begin{array}{l}\text { Easier for men to have } \\
\text { a career }\end{array}$ \\
\hline Cyprus & $\mathrm{M}$ & - & Y-1 & & & UnB & UnB & & \\
\hline Czech Republic & $\mathrm{M}$ & $\mathrm{L}$ & Y-1 & & & UnB & UnB* & & $\begin{array}{l}\text { Women } 46 \% \text { of chief } \\
\text { of staff }\end{array}$ \\
\hline Denmark & $\mathrm{M}$ & $\mathrm{M}$ & Y-1 & $\mathrm{Y}$ & A & UnB & UnB & & \\
\hline Estonia & G & G & Y-1 & $\mathrm{Y}$ & A C & UnB & UnB & & \\
\hline Finland & G & G & $\mathrm{Y}-1$ & $\mathrm{Y}$ & A B C D & UnB & UnB & & \\
\hline France & $\mathrm{L}$ & $\mathrm{M}$ & Y-1 & & & & & & \\
\hline Germany & $\mathrm{L}$ & $\mathrm{L}$ & Y-1 & $\mathrm{N}$ & $\begin{array}{l}\text { A, B C D- } \\
14,15,16 \text { E }\end{array}$ & UnB & UnB & Y-15 & Low representation \\
\hline Greece & $\mathrm{L}$ & $\mathrm{L}$ & Y-1 & & & & & & \\
\hline Hungary & $\mathrm{M}$ & $\mathrm{L}$ & Y-1 & & & & & & \\
\hline Italy & $\mathrm{M}$ & M & Y-1 & & & & & & \\
\hline Latvia & G & G & Y-1 & $\mathrm{Y}$ & A B C D & UnB & UnB & & \\
\hline Lithuania & $\mathrm{M}$ & M & Y-1 & Y & A B C D & UnB & UnB & & \\
\hline Luxembourg & $\mathrm{M}$ & $\mathrm{L}$ & Y-1 & & & & & & \\
\hline The Netherlands & $\mathrm{L}$ & - & Y-1 & & & & & & \\
\hline Norway & $\mathrm{M}$ & G & Y-2 & Y-2 & $\begin{array}{c}\mathrm{A}, \mathrm{B} \mathrm{C}- \\
2,5 \mathrm{D}-10 \\
11,12,13 \mathrm{E}\end{array}$ & UnB & UnB & $\mathrm{Y}$ & \\
\hline Poland & $\mathrm{M}$ & $\mathrm{L}$ & Y-1 & & & & & & $\begin{array}{l}\text { Forest engineers not } \\
\text { balanced, but still at } \\
\text { high level }\end{array}$ \\
\hline Portugal & $\mathrm{M}$ & $\mathrm{M}$ & Y-1 & & A D-8 & $\mathrm{B}$ & B & & \\
\hline Romania & $\mathrm{M}$ & $\mathrm{L}$ & & & & & & & \\
\hline $\begin{array}{l}\text { Serbia and } \\
\text { Montenegro }\end{array}$ & G & - & & & A & UnB & UnB & & \\
\hline Slovakia & $\mathrm{M}$ & G & Y-1 & $\mathrm{Y}$ & & UnB & UnB & & \\
\hline Slovenia & $\mathrm{G}$ & G & Y-1 & & & & & & \\
\hline Spain & $\mathrm{M}$ & $\mathrm{M}$ & Y-1 & & A & UnB & UnB & & \\
\hline Sweden & G & G & Y-1 & Y-2 & $\begin{array}{c}\text { A B C-4 D- } \\
7,8,9 \mathrm{E}\end{array}$ & UnB & UnB & $\mathrm{Y}$ & $\begin{array}{l}\text { Women less paid, } \\
\text { harder to have a career }\end{array}$ \\
\hline Switzerland & $\mathrm{M}$ & $\mathrm{M}$ & & & A & UnB & UnB & & \\
\hline Turkey & $\mathrm{L}$ & - & Yes & & $\mathrm{AC}$ & UnB & UnB & Y-8 & $\begin{array}{l}\text { Related to health, } \\
\text { especially physical }\end{array}$ \\
\hline United Kingdom & $\mathrm{L}$ & $\mathrm{L}$ & Yes & $\mathrm{Y}$ & A C-5 D E & UnB & UnB & $\mathrm{Y}$ & $\begin{array}{l}\text { Differences in } \\
\text { public/private sector } \\
\text { employment in } \\
\text { representation and pay, } \\
\text { but hard to reach senior } \\
\text { levels in both sectors }\end{array}$ \\
\hline $\begin{array}{l}\text { United States of } \\
\text { America }\end{array}$ & G & $\mathrm{M}$ & $\mathrm{Y}$ & No & $\begin{array}{l}\text { A, B C 2,5 } \\
\text { D-19,20,21 }\end{array}$ & UnB & UnB & Y-20 & $\begin{array}{l}\text { Probably some at local } \\
\text { or regional level }\end{array}$ \\
\hline
\end{tabular}




\section{Representation of women in forestry employment}

Quantitative data is known to be too patchy and insufficient to determine, with confidence, the number of women working in the forestry industry, or their roles and employment levels.

There are, however, common themes that emerge from this data and, combined with more qualitative information from research, surveys and anecdotal evidence, provide clear insights as to the nature of gender representation across the industry.

Although the data show that improvements have been made in the number of women holding technical, professional and managerial positions over the last 10 to 15 years, women are still clearly underrepresented in the forestry industry. Similarly, although statistics are not available for the whole supply chain, enough evidence exists to suggest that it is indicative of the whole industry and in most, if not all, participant countries.

\section{THE ROLE OF WOMEN IN THE INDUSTRY}

In terms of seniority levels and positions of decision-making and responsibility, the data and feedback confirmed that it was overwhelmingly unbalanced in favour of men. This was true in all the sectors and countries studied, although there was evidence that more women held senior positions in the public sector (though, even here, the balance still clearly favoured men).

What the information does suggest is that women in the forestry sector are primarily employed in administrative and support roles, with "professional" women foresters tending to have specialist roles (i.e. research), or first-line junior management positions. Moreover, there is limited information (either quantitative or qualitative) on the numbers and roles of women in contracting or self-employed forestry work, as here especially women seem to be invisible.

Examples of good practices, however, have been emerging, which proves that concerted and sustained commitment and planning at the most senior organizational level can result in quantifiable improvements in the number of professional women foresters employed and the level of seniority they can attain. The ToS defined "professional" to mean women who qualified at the university degree level and who worked in forestry or forestry-related roles. This is demonstrated in the United States Forestry Service and detailed in Section 1.15.

The relatively low level of female representation - both in terms of critical mass and levels of seniority/ professional roles - is in stark contrast to the feedback from all respondent countries that gender/equality is perceived as an important issue in society. This was evidenced through referencing national government and international (i.e. United Nations) policies and initiatives, combined with legislative measures to enforce equality. This is further underlined by the fact that all participant countries confirmed that gender equality 
was also considered to be an "issue" within their respective forestry industry. It is therefore important to understand the reasons why the efforts to redress the current imbalance have been unsuccessful.

\subsubsection{Why is gender representation as it is?}

Despite the difficulties in accessing sufficiently robust data sources across all sectors of the industry and for all countries, the data the ToS collected clearly shows that women are underrepresented. This, combined with research studies, survey work and anecdotal evidence, strongly indicates that this is the prevailing situation across the whole industry.

Indeed, a recent study prepared for the European Forest Sector Outlook Study showed that, the share of women in forestry is low in all countries (see section 1.3) (Blombäck, Lövgren, Poschen, 2003).

Despite country-level differences in detail and emphasis, a number of common themes have emerged:

- The status of women in forestry is a reflection of the explicit and implicit values of societies, influenced by the same cultural, social and historical factors that have made it difficult for women to enter and progress in the general labour market. This can be underpinned by perceptions of male and female roles, traditions of inheritance, legislature and infrastructure that serve to endorse differences between work and child-rearing responsibilities. Such perceptions and values can become stereotypes, which drive expectations and pressures around male and female work - both in terms of work content and working patterns.

- This may indicate a situation where women are actively selecting against forestry employment. The number of women in forestry and forestry-related courses tend to be relatively low as compared with men's, a pattern that has been around for at least a decade. Once students, however, women are just as successful as men. The reason as to why so few women study forestry would benefit from further research and more case studies, although existing research and anecdotal evidence suggest that there is a lack of awareness of forestry as a potential career, and that career advice is generally nonexistent or negative about the industry. The industry also seems to have a poor image (either in terms of a prevailing perception of heavy manual work, or associated with forest destruction and environmental disregard). The industry currently seems to do little to counterbalance these negative images. The status of the industry, in some countries, therefore does little to promote it as a good career option for women. In addition, at least in some countries, the economic conditions within the sector have forced mechanization, reduced employment and restructuring of the sector, offering less jobs. 
- The fact that the industry is a highly male-dominated working environment may be a deterrent to many women, who may feel that there is likely to be discrimination and that their opportunities for career development may be hindered. Although there does not appear to be any direct research evidence on this issue, it is a factor highlighted as a deterrent to women considering other maledominated industries (e.g. construction and engineering).

- In terms of the current workforce, there is clear evidence of discriminatory practice against women. In the past, this has been very explicit and in certain sectors anecdotal evidence suggests this is still very much the case, although in many countries the situation has improved since the introduction of equality legislation. Since the introduction of this legislation, discrimination appears to have become more implicit. Many women in the industry refer to the culture being closed to them - reminiscent of a men's "club" - with male focused values and standards.

- There are few opportunities offered within forestry work for part-time or flexible working. This impacts women more than men because women are, more often than not, responsible for childcare responsibilities. Survey work and anecdotal evidence suggest that women are reluctant to request flexible working due to concerns over their career prospects. This can result their leaving the industry completely. However, survey studies also indicate that modern forestry work should be able to accommodate more flexible working than it currently appears to offer.

- The gender imbalance is particularly prevalent within management roles, especially at senior level. Women foresters, however, are likely to be just as well-qualified as men. The fact that they are still failing to achieve senior positions suggests previous and ongoing discrimination at an explicit or implicit level.

\subsubsection{What are the key drivers for change and the actions required in driving the employment gender "agenda" forward?}

As well as policy pressures, some countries are experiencing changes in workforce demographics, with increasing numbers of women seeking to enter or return to the workforce, sometimes exceeding the availability of male recruits.

In addition to these various national and international drivers, there are also issues of what brings women into particular sectors, what motivation or pressures exist for women to study and to work in the forestry industry and how this is manifested across different industry sectors and societal strata. For example, in some countries or particular geographical areas, it is important for women to contribute to household income. This 
is particularly prevalent in rural areas where land-based work is often the mainstay of local employment and where forestry plays a significant role in the local (or indeed the national economy).

In the case of technical and professional roles, there is a higher level of expectation for job satisfaction, self-fulfilment and career advancement. As more women seek to enter employment, these expectations increase.

Data analysed from Germany, Great Britain and the Nordic countries suggest that women (and men) are drawn to the forestry industry by an early interest in nature and the "outdoors". In many cases, this is influenced by positive experiences of living close to or visiting forests when young. This is often compounded by knowing people in the industry (family and friends), or through the support of teachers or careers advisers at school.

Research in these countries, however, suggests that career advice on forestry is at best ambivalent and at worst negative. Probably there are ways and opportunities to educate career advisers and teachers of the career possibilities that forestry offers and to improve the guidance currently offered to children. Therefore, educating advisers and teachers would help to raise the profile of the industry in a more positive way and begin to dispel some of the myths and stereotypes that may be discouraging women from considering forestry as a work choice.

In addition to understanding and addressing some of the motivational factors, which impact on organizational attraction strategy, it is also important to recognize and address key drivers for retaining women (which in turn will impact positively on attraction and recruitment). These may include some or all of the following:

- flexible working provision - legislative measures are making this increasingly easier for parents to access;

- women-only networks - this concept appears to find favour in some countries more than others;

- mentoring for women - either by senior women, or even senior men;

- equal pay, reward and recognition;

- role models - of women undertaking interesting or challenging forestry projects; and

- equal access to training, development and career advancement opportunities.

Additionally, on an industry level it is essential that there is a clear and genuine commitment to gender equality and that this is demonstrated and sustained at the senior level of management. 


\subsubsection{What are the positive benefits to be gained?}

In many respects, it is quite astonishing that in the twenty-first century there is still a call to justify the employment of women and present a business case for a balanced workforce.

There is clear evidence to suggest that women who study forestry are as capable as their male colleagues and that their qualifications are as good, if not better. An increasing body of research across other industries now exists that demonstrates that workplaces are more effective and morale is higher when there is gender balance.

There is also recognition that the skills women bring to the workplace are significantly beneficial to the organization, especially in areas such as interpersonal skills and communication, teamworking, problem solving, creativity and resolving conflict. These skills balance the more traditional, masculine skill base and result in a more balanced approach, offering greater flexibility and responsiveness. Similarly, there is also research, which clearly indicates that women are able to demonstrate a set of skills and abilities that are highly relevant and effective in leading organizations in times of external change and complexity.

Additionally, women are important consumers of forest products and have an important role in influencing purchasing decisions. Yet, to what extent do forestry companies really understand and seek to engage this important and substantial segment of their market?

Tomlin described in her Professional Women Foresters in British ${ }^{1}$ survey forestry employers in Great Britain, across the supply chain, about the most valuable attributes for foresters. Organizations who responded to the survey agreed that the most important attributes included interpersonal skills, technical expertise, initiative, experience and teamwork, whereas physical strength and practical skills were rated as low requirements. None of the most highly valued criteria preclude women and, indeed, many of these areas are those in which women can excel.

Similarly, employers who responded agreed that the advantages women could bring to the workforce include good people management skills, communication skills, team players (were seen to be better than men), creativity (offered different perspectives) and competent at achieving targets. However, despite this overwhelmingly positive view of the benefits women could bring to the workforce, few of the employers surveyed believed there were business benefits to be gained from employing women.

Such a contradiction hardly makes sense and it is clear that forestry organizations are neglecting a significant source of skill, ability and potential as a result of an outmoded and anachronistic culture and ethos.

${ }^{1}$ A study commissioned by Forestry Commission, April 2001, Wildcat One Consulting, Pentlandfield Business Park, The Bush, Roslin, Midlothian EH25 9RE. 
Addressing this will be particularly critical as population and workforce demographics change and reduce the traditional forestry labour pool of young, white men. This is already an issue for northern Europe and the United States.

\section{3 EMPLOYMENT TRENDS - THE EUROPEAN FOREST SECTOR OUTLOOK STUDY}

Blombäck, Lövgren and Poschen from the International Labour Organization (ILO) prepared the study "Employment Trends and Prospects in the European Forest Sector" for the European Forest Sector Outlook Study in 2003. The study reveals gender gaps in forestry and in the forestry sector as a whole. It was undertaken in an effort to broaden the scope to pay closer attention to social aspects of sector development. It focuses on an analysis of recent trends in productivity and labour resources in the European forest sector and analyses the structural changes of the past. The paper includes information about wages, safety and health of working places as well as training and skills of workers. Based on these trends, the paper gives an outlook for social issues in European forestry and the wood processing and pulp and paper industries. The analysis is linked to a discussion about possible future changes in the policy and market framework of the sector. Furthermore, the report includes a gender-sensitive analysis and interpretation of the data available.

In the section of the status and trends of employment and productivity in forestry, the paper states: "The share of women in forestry is low in all countries. Only in 4 countries of the 20 providing data does it reach or exceed 20 percent. The highest share of women employees (26 percent) was reported from Latvia. In most occupations, the proportion of women is on the rise. The only group in the forestry sector in which the share of women has probably stagnated or even declined are the forest workers. This is partly a result of reduced investment in silviculture. The biggest fall has, however, been caused by the transition to market economies in central and eastern Europe. Women were particularly affected by large cuts in the public sector where many of them had service jobs. A general trend in all countries is that women are still strongly underrepresented in management and decision-making".

The study also examined wages and salaries and confirmed that female employees in most countries receive lower pay than their male counterparts; obviously, it is a situation that needs to be remedied if the sector is to attract more women workers in the future.

Concerning socio-economic impacts, the study reveals that rural areas account for more than 80 percent of the European Union's land mass, and even a greater portion of the total area of Europe and the Commonwealth of Independent States. In many countries, the reduction of work in the forestry sector will 
have a severe effect on employment in rural regions. It is estimated that the share of women, already low in most countries, will decline further as investment in silviculture operations follow a negative trend.

The following country-based contributions highlighting gender structures in forestry organizations as well as those in family forestry give detailed evidence to the study`s conclusions. At the same time, they show that changes are occurring and that raising gender awareness is important and crucial for the future of forestry as an important sector for both rural and urban societies.

\subsection{ARMENIA}

By Hakobjanyan Inna, researcher at the Forestry Department of the Armenian State Agrarian University

\subsubsection{Introduction:}

Following Armenia's independence in 1991, economic problems (including a serious economic and transport blockade), widespread social difficulties and armed conflict with neighbouring Azerbaijan removed the gender topic from public attention and opinion. Not surprisingly, the difficult social and economic situation in the country affected women more than men.

The forested area in Armenia amounts to 334100 hectares. For Armenians, forests are a source of timber, fuelwood, non-timber forest products and game meat; the forest is used by a large number of people for subsistence purposes. In recent years, an extensive area of beech and oak forests and shrublands close to population centres became the main source of fuelwood - both women and men spent much time gathering fuelwood for domestic heating and cooking purposes - which, as a result, has reduced the forest's resource base and degraded forest areas.

\subsubsection{Socio-demographic situation in Armenia, including gender issues}

Armenia is a landlocked country with an area of $29800 \mathrm{~km}^{2}$ and a population of 3212200 (2004). In Armenia, where 35.8 percent of the population live in villages, patriarchal social structures still rule the relationships between men and women. As mothers and housewives, women are responsible for all domestic and child-rearing chores, and as agricultural workers they contribute a large proportion of the total household labour of the family farm enterprise. Women are also primarily responsible for processing and storing food for the local market, or for consumption during the winter months. Older women generally control the processing of agricultural products and make decisions on household consumption. With the increasing emigration of men, a growing number of households are de facto women headed. Despite this, the majority of women have little or no direct influence on village-level decision-making. 


\subsubsection{Gender structure in Armenian forestry}

A major problem in the forestry sector is that it lacks professional foresters and forest technicians who have sufficient education and experience in active forest management. There are few, if any, foresters with bachelor's or master's degrees in forestry, although there are many skilled biologists with different specialities in forestry and geographers with experience in international forestry.

Reliable information on the actual condition of women in forestry is not available; however, gender issues are increasingly being recognized as important and the necessity for advanced research and understanding of gender aspects in forestry has been acknowledged.

\section{Armenian state forest service "Hayantar"}

State forests are managed by the state forest service "Hayantar", which is part of the Ministry of Agriculture. Based on the administrative regions of the country, Hayantar is divided into 22 forest enterprises, with the average enterprise managing less than 16000 hectares of forestland. Statistically, of the 926 employees that make up the regional forest enterprises, 10 percent are women, and of the 52 employees in the central office in Yerevan, 42 percent are women.

In the regional enterprises, women are mainly engaged in planting activities, and in both the regional centres and the central office women are usually employed as accountants, typists or secretaries - in both the regional centres and the central office women do not hold any decision-making positions. Less than 5 percent of the forestry staff has some professional (forestry) training, although more than 95 percent have a wide range of different specializations, which in some cases does not include agriculture and other related occupations.

Very few women are employed in the regional forest enterprises; furthermore, there are hardly any professional women foresters (see Table 3). One of the reasons for the low participation rate is that role models of female foresters in Armenia have never existed, culturally and traditionally.

Table 3: Composition of women in Armenian forest enterprises

\begin{tabular}{ccc}
\hline Forest enterprise & Total number of employees & \% women \\
\hline Ijevan & 50 & 12 \\
\hline Gougark & 85 & 14 \\
\hline Hrazdan & 58 & 5 \\
\hline Eghegis & 30 & $>2$ \\
\hline
\end{tabular}

\subsubsection{Employment at other Armenian forestry agencies}

Table 4 highlights the proportion of women employed at four Armenian forestry agencies and institutes. The Institute of Botany, interestingly, is the only agency where women constitute the majority of the workforce. 
Table 4: Representation of women in the workforce at four forestry agencies

\begin{tabular}{lccc}
\hline Agency & Total staff & Men & Women \\
\hline Forest Management Agency & 6 & 5 & 1 \\
\hline Forest Research and Experimental Centre & $28 *$ & 27 & 1 \\
\hline Institute of Botany & 84 & 25 & 59 \\
\hline Bioresources Agency & 27 & 19 & 8 \\
\hline
\end{tabular}

*Of the 28 employees, 26 have temporary contracts.

\section{Armenian State Agrarian University (ASAU) forestry department}

The only possibility where students can achieve a higher forestry education - a specialization in "Forest Enterprise and Settlement Greening" - is through the forestry department at ASAU, which was established in 2003. Two other specializations, Forest Engineering and Forest Park Gardening - were taken out of the curriculum in September 2003, but are presented as an example of student coursework and gender distribution in Table 5 below. Additionally, the university initiated a distance-learning programme in forestry in 2005, with 4 women and 18 men currently enrolled.

At present, the university has two women laboratory assistants, and two women and six men lecturing in the forestry department. Few of the lecturers have an educational background in forestry; however, they have work experience in Armenian forestry and two of them undertook special forestry training courses at leading universities in Europe and the United States.

Table 5. Student distribution in forestry courses at ASAU (2002/2003 academic year)

\begin{tabular}{lcccc}
\hline Specialization & Course & Total enrolment & Men & Women \\
\hline Forest Engineering & $1^{\text {st }}$ & 24 & 23 & 1 \\
\hline $2^{\text {nd }}$ & 25 & 18 & 16 & 6 \\
\hline Forest Park Gardening & $3^{\text {rd }}$ & 13 & 8 & 5 \\
\hline & $4^{\text {th }}$ & 24 & 14 & 10 \\
\hline & $1^{\text {st }}$ & 15 & 10 & 10 \\
\hline $2^{\text {nd }}$ & $3^{\text {td }}$ & 18 & 8 & 6 \\
\hline
\end{tabular}

Master of Science level study

\begin{tabular}{lccc}
\hline Programme & Number of courses & Men & Women \\
\hline Forest Engineering & 2 & 2 & 4 \\
\hline & 1 & 1 & 3 \\
\hline Forest Park Gardening & 2 & 1 & 3 \\
\hline
\end{tabular}




\section{Greens' Union of Armenia, a non-governmental organization}

The Greens' Union of Armenia is a non-governmental organization specializing in environmental awareness and protection. It has about 6000 members (central office and regional branches), with members generally young and with varying educational backgrounds; the gender distribution is 35 percent men and 65 percent women.

\subsubsection{Conclusions}

Although the Armenian forestry sector as a whole has serious employment problems, it is especially hard on women. Many potential employers such as the Armenian State Forestry Agency continue to prefer to hire and staff their offices with male foresters. Employment prospects for female foresters are rather dismal and not expected to change in the near future.

\subsection{CANADA}

\section{An overview of public and private organizations in the Canadian forest sector}

By Mike Fullerton, International Affairs, Canadian Forest Service, Natural Resources Canada

\section{Preamble}

This paper presents an overview of the representation of women in some, but not all, public and private organizations that make up the Canadian forest sector. The Canadian Forest Service, which is part of Natural Resources Canada, and the key forestry-related private sectors, will be examined. To start, the important gender equity tools that are available to Canadians will be reviewed: the Employment Equity Act and gender-based analysis.

\subsubsection{The Employment Equity Framework in Canada}

In Canada, the Employment Equity Act (1995) is the principal piece of legislation that governs employment equity in the Canadian workforce. The Employment Equity Act is intended to ensure that each designated group is equitably represented within a given occupational group. The designated groups covered in this Act are women, aboriginal peoples, persons with disabilities and members of visible minorities. Occupational groups are categorized according to a National Occupational Classification system.

Equitable representation is outlined in Article 5(b), which states that:

5. Every employer shall implement employment equity by

(b) instituting such positive policies and practices and making such reasonable accommodations as will ensure that persons in designated groups achieve a degree of representation in each occupational 
group in the employer's workforce that reflects their representation in

(i) the Canadian workforce, or

(ii) those segments of the Canadian workforce that are identifiable by qualification, eligibility or geography and from which the employer may reasonably be expected to draw employees.

Therefore, a given employer is required to have a workforce that reflects the demographics of the overall Canadian workforce in terms of the percentage of each designated group within each occupational group, which is referred to as the workforce availability. Under the Act, employers are required to conduct an analysis of their workforce to assess the degree of underrepresentation of persons in designated groups in each occupational group compared with the workforce availability.

\subsubsection{Gender-based analysis}

In 1995, the Government of Canada adopted a policy requiring federal departments and agencies to conduct gender-based analysis of future policies and legislation, where appropriate. This policy stemmed from Canada's commitments under the Beijing Platform for Action and the federal document "Setting the Stage for the Next Century: The Federal Plan for Gender Equality (1995-2000)" in which the implementation of genderbased analysis was the first objective.

Gender-based analysis is an analytical tool that is used to assist in systematically integrating gender considerations into the policy, planning and decision-making processes within the federal government. Gender-based analysis is a process that assesses the differential impact of proposed and/or existing policies, programmes and legislation on women and men. It makes it possible for policy to be undertaken with an appreciation of gender differences, of the nature of relationships between women and men, and of their different social realities, life expectations and economic circumstances. It is a tool for understanding social processes and for responding with informed and equitable options.

Gender-based analysis compares how and why women and men are affected by policy issues, and challenges the assumption that everyone is affected by policies, programmes and legislation in the same way regardless of gender, a notion often referred to as "gender-neutral policy".

The Federal Plan clearly states departments' and agencies' responsibility for gender-based analysis and envisaged that implementation would be phased in over a five-year period, as departments and agencies developed the necessary expertise and capacity. Status of Women Canada, the federal department responsible for gender equity, is responsible for collaborating with other departments in developing tools, training materials and procedures for gender-based analysis and for monitoring the process. 
Gender-based analysis will be particularly important for science-based resource departments within the Canadian government, where many science and technology occupations are male dominated and the resource sector itself is male dominated. Integrating gender-based analysis in these departments will strengthen their ability to propose and deliver policy and programmes that are gender conscious.

\subsubsection{Gender issues in Natural Resources Canada and the Canadian forest service}

Natural Resources Canada (NRCan) is the federal department responsible for the sustainable development of energy resources, mined resources, and forests at a national level. NRCan is one of a handful of science-based departments where a comprehensive knowledge of science-based issues and scientific research are necessary for delivering on its mandate.

In Canada, the natural resources sector and science and technology occupations are predominantly male. As a science-based department in the natural resources, NRCan faces significant challenges in gender equality. Table 6 presents the percentage of women in the major occupational categories as well as the ratio between the number of female employees in the field and the workforce availability. If the ratio is 100 percent then there is no gap between the departmental composition and the workforce availability, which is an indication of the employment equity targets for a given occupation. If the ratio is below 100 percent then there is a gap; a ratio of 80 percent or below is considered to be a significant gap.

Table 6: Female representation by occupational category for NRCan

\begin{tabular}{lcc}
\hline Occupational category & Female employees (\%) & $\begin{array}{c}\text { Ratio } \\
\text { (\%) workforce availability) }\end{array}$ \\
\hline Executive & 26 & 78 \\
\hline Science professionals & 24.5 & 98 \\
\hline Administration and foreign service & 56.6 & 96 \\
\hline Technical & 30.4 & 94 \\
\hline Administrative support & 80.6 & 100 \\
\hline Operational & 4.9 & 32 \\
\hline Total & 39 & 96 \\
\hline
\end{tabular}

Women make up 39 percent of the department's workforce, which is below the Canadian public service average of 51.5 percent. The biggest concern to emerge from these data is the underrepresentation of women in the executive-level category, which consists of senior managers and decision makers. At the departmental level, NRCan is 22 percent below the workforce availability target for this category. Unfortunately, the gap is wider in certain sectors within the department.

Below is a similar table (Table 7) for the Canadian Forest Service, the sector within NRCan that is responsible for the sustainable development of Canada's forests. The Canadian Forest Service has 
its headquarters in Ottawa, Ontario, with five regional laboratories throughout the country. As with the department as a whole, the Canadian Forest Service as a science and resources agency has a predominantly male workforce.

Table 7: Female representation by occupational category for the Canadian Forest Service

\begin{tabular}{lcc}
\hline Occupational category & Female employees (\%) & $\begin{array}{c}\text { Ratio } \\
\text { (\% workforce availability) }\end{array}$ \\
\hline Executive & 15.8 & 47 \\
\hline Science professionals & 20 & 72 \\
\hline Administration and foreign service & 52.1 & 93 \\
\hline Technical & 33.6 & 106 \\
\hline Administrative support & 93.9 & 116 \\
\hline Operational & 6.1 & 52 \\
\hline Total & 34 & 90 \\
\hline
\end{tabular}

Women make up 34 percent of the Canadian Forest Service workforce, which reflects 90 percent of the employment equity target as represented by workforce availability. When looking at the organization more closely, however, it becomes apparent that women are largely underrepresented in some occupations and overrepresented in others. At the executive level, only 15.8 percent of employees are women reflecting a largely significant gap when compared with the workforce availability. Significant gaps are also present in the science professionals' category and the operational occupations. Contrary to this, women are overrepresented in the technical and administrative support categories when compared with workforce availability.

NRCan has taken a number of gender-equality initiatives to address the underrepresentation of females, such as the creation of an Employee Women's Network, female representation on research promotion boards and recruitment boards, and the Interdepartmental Task Group on Women in the Federal Science and Technology Community. Within the work of the Employee Women's Network, a ten-year demographic study of gender and career progression within the department was initiated.

Although the department's initiatives point us in the right direction, they do not address the magnitude of the challenge faced by the natural resources sector. Initiating gender-based analysis gender-based analysis as part of the department's external policy and programme analysis and development would be the next step to accelerating gender-based analysis and strengthening the department's policy capacity. To date, NRCan has used the tool for internal policy development, particularly in human resources' policies, and is investigating the appropriateness and feasibility of gender-based analysis as a first step towards using the tool for external applications. 


\subsubsection{Gender statistics for the Canadian forest sector}

As is the case with public forest-related organizations, private industry within the Canadian forest sector has a significant underrepresentation of women when compared with other industries. In 2001, 16.4 percent of all employees in the forest industries were female (Table 8) compared with 47.6 percent for all other industries. Although 16.4 percent is far below average, it does show an increase in female employees since 1996. Labour data for the forest industries is derived from the employees in the following areas:

- Forestry and logging

- Support services for forestry

- Wood manufacturing

- Pulp and paper manufacturing

- Furniture manufacturing

Table 8: Percentage of female and male employees in the forest industries

\begin{tabular}{lcc}
\hline Year & Female employees (\%) & Male employees (\%) \\
\hline 1996 & 13.9 & 86.1 \\
\hline 2001 & 16.4 & 83.6 \\
\hline
\end{tabular}

Source: Statistics Canada; data are from the 1996 and 2001 census.

Within the forest industries, there is a smaller percentage of females in management positions when compared with males, but there is a greater percentage of females in positions requiring a university degree (skill level A). Table 9 presents the data.

Table 9: Percentage of all employees in management positions and positions requiring skill level $\mathrm{A}$ in forest industries for 2001, by sex

\begin{tabular}{lcc}
\hline Positions & Female (\%) & Male (\%) \\
\hline Management & 4.8 & 6.5 \\
\hline Skill level A & 5.8 & 3.1 \\
\hline
\end{tabular}

Source: Statistics Canada.

Based on the preliminary data, the Canadian forest sector is predominantly male even with the recent increase in female employees. Females continue to be underrepresented at the management level despite the presence of more educated females working in the forest industries.

\subsubsection{Gender demographics of Canadian university graduates}

The number of females employed in the Canadian forest sector is in part a reflection of the number of females with academic qualifications in forestry-related fields. Table 10 shows the percentage of women with academic qualifications in forestry. The data are categorized by age group for 1991, 1996 and 2001. General 
forestry, forest engineering, forest wildlife management and other forestry disciplines are the fields of study that make up these data.

Table 10: Percentage of females with academic qualifications in the forestry field, by age

\begin{tabular}{ccccc}
\hline Year & All Ages & $\mathbf{2 0 - 3 4}$ & $\mathbf{3 5 - 4 4}$ & $\mathbf{4 5 - 6 4}$ \\
\hline 1991 & $10.5 \%$ & $21.5 \%$ & $7.8 \%$ & $1.9 \%$ \\
\hline 1996 & $13.5 \%$ & $22.5 \%$ & $18.7 \%$ & $2.9 \%$ \\
\hline 2001 & $13.2 \%$ & $28.3 \%$ & $18.8 \%$ & $7.8 \%$ \\
\hline
\end{tabular}

These numbers illustrate that more females are studying forestry as shown by the decrease in percentages with age and an increase in percentages with time. In 2001, more than one quarter of young qualified individuals (age 20-34) were women.

Table 11 details the employment activity of individuals whose highest post-secondary qualification is in the field of forestry. Out of all qualified individuals, 84.8 percent of females and 84.5 percent of males were in the labour force in 2001, with 15.8 percent of all labour force participants being female. Of the labour force participants, 22 percent of women were unemployed, with unemployment rates for women and men being 11.5 percent and 7.6 percent respectively. Conversely, 15.2 percent of those employed are female, with employment rates of 75.1 percent and 78.1 percent for women and men.

Table 11: Employment of individuals with academic qualifications in forestry fields for all ages (2001)

\begin{tabular}{|c|c|c|c|c|c|c|c|c|}
\hline Gender & $\begin{array}{c}\text { Total } \\
\text { qualified }\end{array}$ & $\begin{array}{l}\text { In labour } \\
\text { force }\end{array}$ & Employed & Unemployed & $\begin{array}{l}\text { Not in } \\
\text { labour } \\
\text { force }\end{array}$ & $\begin{array}{c}\text { Participation } \\
\text { rate } \\
(\%)\end{array}$ & $\begin{array}{l}\text { Employment } \\
\text { rate } \\
(\%)\end{array}$ & $\begin{array}{c}\text { Unemployment } \\
\text { rate } \\
(\%)\end{array}$ \\
\hline Female & 4815 & 4085 & 3615 & 470 & 735 & 84.8 & 75.1 & 11.5 \\
\hline Male & 25610 & 21645 & 19990 & 1655 & 3960 & 84.5 & 78.1 & 7.6 \\
\hline Total & 30425 & 25730 & 23600 & 2130 & 4695 & 84.6 & 77.6 & 8.3 \\
\hline
\end{tabular}

It should be noted that even though employees whose major field of study was forestry are not necessarily working in the forestry field. These employment figures represent all occupations. Likewise, those employed in forestry occupations do not necessarily have a formal education in forestry. These data are intended to show the availability of individuals trained in forestry-related disciplines.

\subsubsection{Conclusion}

Modest progress is being made towards gender equity in the Canadian forest sector; however, private and public forestry-related organizations continue to be predominantly male. Tools like the Employment Equity Act and gender-based analysis will assist in providing direction and targets for advancing towards employment equity and ensuring that the policies and programmes that emerge from federal institutions are gender conscious despite male domination in resource and science-based departments. 
The steady growth in the education of women is a positive sign for continued progress towards gender equity. Particularly encouraging is the presence of more educated women working in the forest sector. One would expect this positive education trend to be reflected in the labour force; however, the higher unemployment rate for qualified women in forestry is troubling and could work against the progress towards gender equity in the workplace.

Further research into the statistics presented in this paper will allow us to gain a deeper understanding of gender in Canadian forestry. For example, it would be interesting to know the barriers that educated women face when trying to find careers in forestry and when trying to advance once they are in the field. As an example, it would be helpful to know what proportion of individuals employed in the forest sector have been academically trained in forestry as well as which sectors individuals trained in forestry are working in other than the forest sector. Such information will provide insight into the potential challenges women are facing when trying to find work in their field such as competition from those trained in other skills.

\section{6 CROATIA}

\section{Women in Croatian forestry}

By Željka Ivanović and Marilena Idřojtić

\subsubsection{Summary}

Forests and forestland cover 43.5 percent of state territory in Croatia; 84 percent of this forestland is covered with forest vegetation. A significant part of forest area is located in the karst region (42 percent). Forests and forestlands are primarily owned by the state ( 82 percent), and managed by the state enterprise "Croatian Forests" Inc., in Zagreb.

To understand women's situation in the forestry sector, research studies - mainly in the form of a questionnaire - were conducted at three institutions in Croatia - the University of Zagreb, Faculty of Forestry, the Forest Research Institute, Jastrebarsko, and “Croatian Forests” Inc., Zagreb. In 2000, these institutions examined the percentage of employed qualified women (i.e. forestry engineers, Masters of Science and Doctors of Science), their age classes and positions. The questionnaire showed the status, obstacles and opportunities that women have in Croatian forestry as well as their participation in decision-making. 


\subsubsection{Introduction}

The main institutions that work on the conservation and development of forests in Croatia are the Ministry of Agriculture and Forestry, the Ministry of Environment and Physical Planning, the University of Zagreb, Faculty of Forestry, and the Forest Research Institute, Jastrebarsko.

\section{University of Zagreb, Faculty of Forestry}

The Faculty of Forestry at the University of Zagreb is, so far, the only institution providing forestry education and training for graduate and postgraduate studies. In academic year 2000/2001, 602 students were enrolled in the programme at the university, 24.1 percent of whom were women. The curriculum and research are conducted in the Forestry and Wood Technology departments. Of the 43 employees, all of whom have degrees in forest engineering or a Master of Science or Doctorate, only three are women (see Table 12).

\section{Forest Research Institute, Jastrebarsko}

The Forest Research Institute was established through the merger of the Institute for Forest Research in Zagreb, the Institute for Seed Husbandry in Rijeka, and the Institute for Conifer Tree Species in Jastrebarsko. It has five scientific departments and is the only such institute in Croatia. Of the 26 employees who have a degree as forest engineer, or a Master of Science or Doctorate, six are women (Table 12).

\section{State enterprise “Croatian Forests" Inc., Zagreb}

State-owned forests and forestland are managed by the state enterprise "Croatian Forests” Inc., Zagreb, and consists of headquarters, 16 regional forest administration offices and 171 forest stations. The sustainable management and preservation of natural structures and diversity of forests are the enterprise's main objectives. The enterprise employs 10000 people and is currently undergoing a process of restructuring. Of the 1118 employees with degrees in forest engineering, a Master of Science or Ph.D., 191 are women (Table 12).

Table 12: Proportion of women at the Faculty of Forestry, the Forest Research Institute, Jastrebarsko, and the State Enterprise "Croatian Forests", Inc.

\begin{tabular}{lcccccc}
\hline & \multicolumn{2}{c}{$\begin{array}{c}\text { Faculty of Forestry } \\
\text { Forestry Department }\end{array}$} & \multicolumn{2}{c}{$\begin{array}{c}\text { Forest Research } \\
\text { Institute, Jastrebarsko }\end{array}$} & \multicolumn{2}{c}{$\begin{array}{c}\text { State Enterprise “Croatian } \\
\text { Forests”, Inc. }\end{array}$} \\
\hline $\begin{array}{l}\text { No. of } \\
\text { employees }\end{array}$ & $\begin{array}{c}\text { Women } \\
\mathbf{( \% )}\end{array}$ & $\begin{array}{c}\text { No. of } \\
\text { employees }\end{array}$ & $\begin{array}{c}\text { Women } \\
\mathbf{( \% )}\end{array}$ & $\begin{array}{c}\text { No. of } \\
\text { employees }\end{array}$ & $\begin{array}{c}\text { Women } \\
\mathbf{( \% )}\end{array}$ \\
\hline Forestry Engineers & 14 & 7.1 & 12 & 25.0 & 1074 & 17.1 \\
\hline Master of Science & 9 & 0 & 9 & 33.3 & 40 & 4 \\
\hline Ph.D. & 20 & 10.0 & 5 & 0 & 1118 & 17.5 \\
\hline Total & 43 & 7.0 & 26 & 23.1 & 4 \\
\hline
\end{tabular}




\subsubsection{Methodology}

Research was carried out through an anonymous questionnaire that was sent to 200 female employees who work as forestry engineers, or who have a Master of Science or Ph.D. in forestry at the University of Zagreb, Faculty of Forestry (Forestry Department); the Forest Research Institute, Jastrebarsko; and the state enterprise "Croatian Forests" Inc., Zagreb (cf. Table 13). The questionnaire contained six general questions and 24 statements that were to be answered with Yes, No, or I don't know. An analysis was made of the jobs they obtained, current posts, acquisition of additional qualifications, competitors, their family situation and opportunities in Croatian forestry. The results of the research are presented jointly for all three institutions.

\subsubsection{Results}

The questionnaire was answered by 157 of 200 women ( 78.5 percent). The general data include age, marital status and number of children. Most of the employed women (65 percent) are between 31 and 40 years of age, 61.8 percent are married, and 31.2 percent are single. Women who do not have children accounted for 37 percent, while 29.9 percent have two children, and 22.3 percent have one child.

Moreover, a high percentage of women - 81.5 percent - claimed to be satisfied with having chosen forestry as their profession, which is a positive sign for women beginning their careers in the forestry professions. Given that 92.4 percent of women have a male as their immediate superior, it is evident that there are very few women holding leadership positions in the forestry industry; the women's opinion, however, is that there is not a proportionate number of women in lead positions ( 88.5 percent). Few women improved their professional knowledge abroad, only 3.8 percent - the same percentage as the women actively engaged with international forestry institutions. Although two-thirds of the women (64.3 percent) desired a higher position at work, some women faced problems: 13.4 percent stated that their family was an obstacle for further career advancement, while 10.8 percent believed their immediate superior inhibited their career advancement. Interestingly, 70.5 percent of women said that they would have advanced much quicker in their career if they had been men. Furthermore, most of the women (83.3 percent) do not have communication problems with forest workers; 69.4 percent do not work less on the field than their male colleagues; and 81.5 percent prefer fieldwork to office work. Significantly, 83.9 percent of the women stated that forestry should not remain a profession reserved primarily for men. 
Table 13: Opinions of Croatian women foresters regarding professional development

\begin{tabular}{|c|c|c|c|}
\hline Statement & $\begin{array}{l}\text { Yes } \\
(\%)\end{array}$ & $\begin{array}{l}\text { No } \\
(\%)\end{array}$ & $\begin{array}{l}\text { Don't know } \\
(\%)\end{array}$ \\
\hline I am satisfied to have chosen forestry as my profession & 82.1 & 9.6 & 8.3 \\
\hline My immediate superior is a male & 92.4 & 7.6 & 0 \\
\hline $\begin{array}{l}\text { I improved my professional knowledge abroad. I am actively engaged with } \\
\text { and international forestry institution }\end{array}$ & 3.8 & 96.2 & 0 \\
\hline My ambition is to achieve a higher position at work & 64.3 & 21.0 & 14.7 \\
\hline My family duties are an obstacle for my career advancement & 13.4 & 82.8 & 3.8 \\
\hline My career is inhibited by my immediate superior & 10.8 & 72.6 & 16.6 \\
\hline As profession, forestry should be reserved primarily for men & 7.1 & 83.9 & 9.0 \\
\hline
\end{tabular}

\subsubsection{Conclusions}

In Croatia, forestry has been and still is a line of business dominated by men. Women have had a difficult time reaching higher positions and participating in decision-making. However, the results of this research have shown that women who work as forestry engineers, or who have a higher degree - Master of Science or Doctor of Science in the forestry field - are content with their work.

\subsection{FINLAND}

\section{Finnish female foresters' employment and career development}

By Katja Turunen and Ritva Toivonen

\subsubsection{Background}

In the mid-1990s, women's employment rate in Finland was the highest of all the member countries in the Organisation for Economic Co-operation and Development agency (Thernborn, 1995). It could be said that men's and women's participation in working life is nearly equal in Finland. According to Gutek (1985) and Kinnunen and Korvajärvi (1996), most professions can be characterized by "gender", i.e. the professions are related to the gender most represented in that profession. In Finland, the state appointments' share of women in leading positions has lately increased and is now up to 20 percent. Still, women are a minority in top management positions, and as evidenced by Finnish companies listed on the stock exchange only 16 percent of them chose a woman to be director in 2003 (Taloussanomat, 2003).

The high quality of forestry university education and the high esteem of the profession in Finland are widely promoted. The union of Finnish Foresters, among other tasks and activities, finances studies on the employment of foresters. In 2004, results from earlier studies about foresters, especially female foresters' employment situation and career development, were collected and analysed. 
One of the major aims of the project was to examine the female foresters' employment situation and the progression of their careers compared with those of male foresters. The number and proportion of female foresters in the sector and their remuneration were among some of the issues studied. In this paper, some of the most important results will be highlighted.

For a long time, women foresters were very unusual in the Finnish forestry sector. The first women forester graduated in 1921, and by 1964 there were 33 women forestry graduates. According to Kärkkäinen and Toivanen (1995), the careers of the first women foresters were rather rugged - being a sole woman in a forestry organization or on a team could not have been an easy one. Although today almost a quarter of foresters are women, they still experience more gender-related problems on the job than their male colleagues.

\subsubsection{Data}

The results presented in this paper are based on studies conducted between 1987 and 2003. Several other studies investigating Finnish foresters' employment and careers were completed during that time, but the studies were independent and comparing their results, in terms of exact figures, is not possible. However, trends can be recognized. The main sources for this paper are Kärkkäinen and Toivanen (1995), Ihalainen (1987), Kaipainen (1998), Turunen (2002), and the Society of Finnish Professional Foresters (SFPF), 2003.

\subsubsection{Results}

There are some 2500 Finnish foresters in active working life, of which 24 percent are women. If the current trend continues, it is projected that women will make up 30 percent of the forestry workforce by 2008 . Women who are under 30 years of age already compose about 50 percent of foresters (Figure 1).

Figure 1: Finnish foresters' gender structure by age groups (2004)

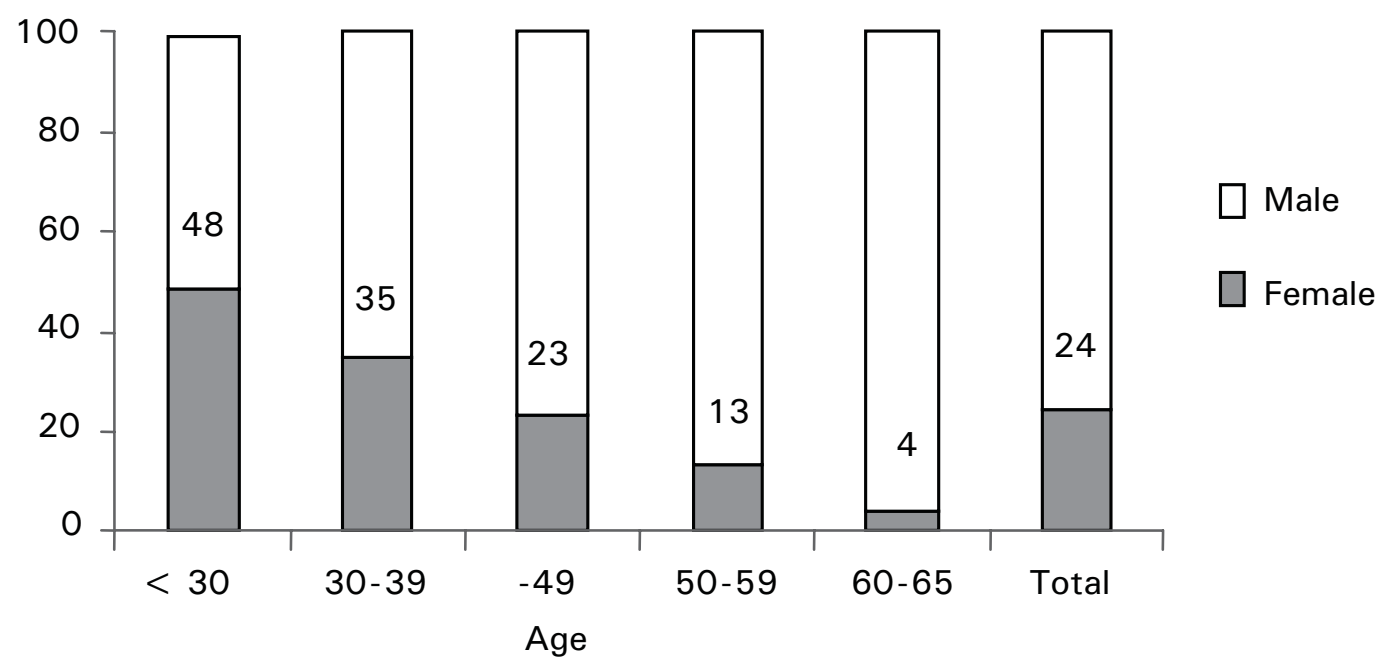


The Finnish forestry sector continues to be a "male dominated" workplace as men account for almost 75 percent of actively working foresters. The occupations in the sector seem to be divided into men's and women's work. Some jobs have very few women while other jobs seem to be particularly related to women's work (Ihalainen, 1987; Kaipainen, 1998; Turunen, 2002).

\section{Employment outside the traditional forestry sector has become more common.}

In the 1970s and early 1980s, about 70 percent of all foresters were employed in public sector forestry organizations (Ihalainen, 1987). Though this was the same for female and male foresters, the types of jobs varied. While women worked in administration positions and at universities and schools, men worked in the practical operations of the forestry sector.

At the beginning of the 1990s, together with the economic downturn, general problems regarding employment in the Finnish forestry sector began to surface. Many foresters were forced to work in other sectors. Kaipainen (1998) reveals that 20 percent of women and nearly 9 percent of men worked outside the traditional forest sector.

In 2000, about 66 percent of men who had graduated in the 1990s worked mainly in the forestry sector, 11 percent outside the forestry sector, and 21 percent both in forestry and in other sectors. During this same period, about 50 percent of female foresters worked only in the forestry sector, 16 percent outside the sector, and about 33 percent in both forestry and other sectors. Even acknowledging the advancements women have made, in the early 2000s there were still fewer women employed in the Finnish forestry sector as compared with men (Turunen, 2002).

Results from a recent study conducted by SFPF in 2003 has shown that the Forest Research Institute, universities and the public sector in general are the biggest employers of female foresters, while forest industry organizations are the most common employers of male foresters.

Although the reasons for the differences in the employment profiles of male and female foresters have not been thoroughly analysed, Kaipainen (1998) posits that female foresters may have experienced more difficulties in finding work in the traditional forestry sector.

Probably this has led women to seek employment outside the forestry sector as they are reluctant to remain without a job; it is likely that it has also encouraged women to accept jobs below their educational level and outside their specialty (Asplund, 1986).

Uncertainty in female foresters' careers has increased rather than decreased. Unemployment and temporary employment is more common among female foresters than with male foresters. In 2003,32 percent 
of female foresters were temporarily employed, compared with 14 percent of male foresters (Kaipainen, 1998; Turunen, 2002; SFPF, 2003). This difference can be partly explained by the differences in ages between male and female foresters.

In Kaipainen's study (1998), 90 percent of men and about 80 percent of women believed their employment suited their education. However, it is clear from the research material that more men are in top management positions than women. While 40 percent of women worked as specialists, only 3 percent held top management positions (SFPF 2003), and many, particularly younger woman foresters, worked as office clerks. In comparison, 34 percent of men were employed in middle and upper management. One possible explanation for this discrepancy is that men may be more active when applying for advanced responsibilities (Kaipainen, 1998).

\section{Salary development}

The most detailed analysis of foresters' salaries is from Pekka Immeli's study (reported in Hankala, 1998). According to Immeli's results, the actual difference (e.g. influence of positions and other similar factors were eliminated) in male and female foresters' salaries in 1996 was 9 percent, see Figure 2. According to the SFPF study of 2003, men usually have higher monthly salaries, both in the private and public sectors.

Figure 2: Differences in salaries between genders in 1996

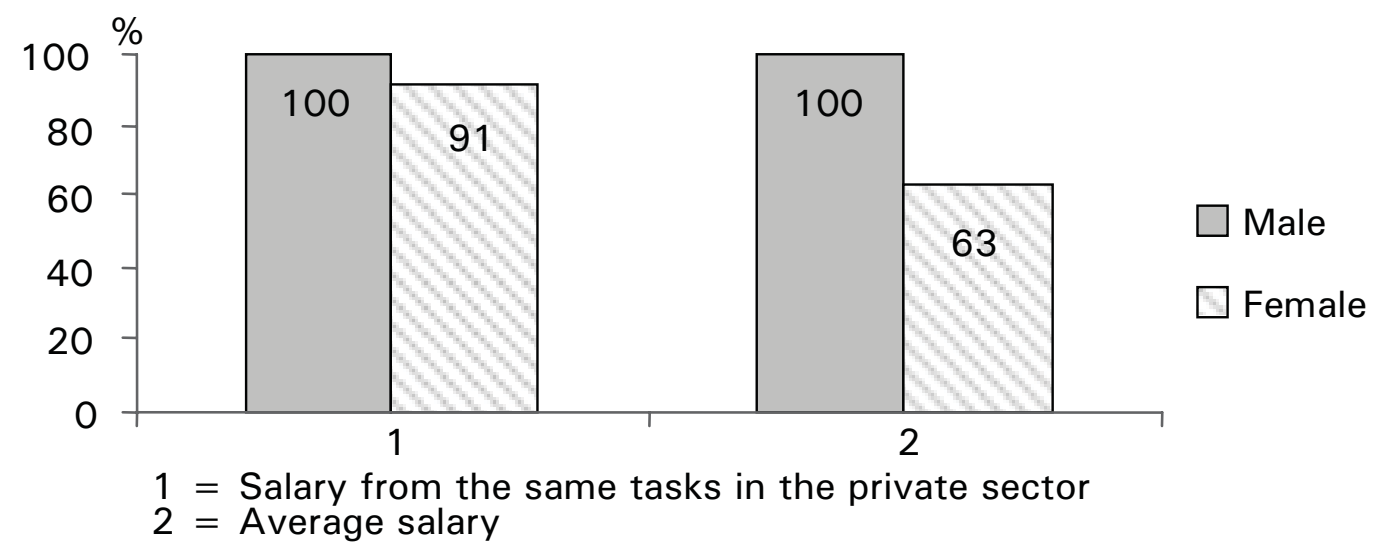

Source: Hankala, 1998.

\subsubsection{Activities to develop women foresters' careers in Finland}

Measures are needed to promote work-related equality among Finnish foresters. The Society of Finnish Professional Foresters (SFPF) supports all efforts and has promoted activities to improve the careers of female foresters, which include organizing seminars and providing occasions where female foresters can meet each other for networking. More publicity is needed, however, to spread the message about female foresters and their careers, the skills they possess and their opinions on current topics of interest in the forestry sector.

Gender equity can also be enhanced by including female representatives in the different committees and 
groups of the SFPF. To this end, the first mentor programme for women was launched in the autumn of 2005. The programme targets women at the beginning of their careers and to those who are returning to work after having had children.

\subsubsection{Conclusions}

This paper has presented an analysis of research studies concerning the employment situation of Finnish male and female foresters and their career development paths. The studies have revealed that women foresters have traditionally been employed more often outside the traditional forest sector than their male colleagues. Further research examining this specific aspect needs to be carried out to determine the reasons why this is occurring. At present, the employment situation concerning female foresters seems to be somewhat weaker than their male counterparts. According to a study by Suutari (2003), the most important step for students is at the point when they finish university and accept their first job. Therefore, because the recruitment phase seems to be the one of the most important phases for female foresters, more attention needs to be devoted at this stage. In summary, the proportion of women foresters of all the foresters in Finland is increasing, and it would be a waste of resources if women remain underutilized in the forestry sector and society.

\subsection{GERMANY}

\section{By Marion Karmann and Siegfried Lewark.}

Forests cover one-third of the national territory (about 10 million hectares) and are habitats of high economic, ecological and social importance. The use of natural resources, their healthy development and conservation are matters of concern to society. Even though the key market product is raw wood, other forest goods enjoying particular attention in society are primarily those shaping the direct living environment of the individual such as the opportunity for recreation in nature or other services (e.g. soil conservation).

Around 46 percent of the forests, mostly smaller than one hectare, are owned by 1.3 million private owners. The Laender (federal states of Germany) own 31 percent of the forest area, public law corporations 20 percent, and the federal government 3 percent. National statistics on ownership distribution do not include the gender ratio. Because special legal heritage constraints do not exist, theoretically women might own 50 percent of these areas. An extensive representative study on smallscale forestry in Baden-Württemberg (southwestern Germany) revealed proportions of female ownership (Steinkamp, 1983): 23 percent of all private forests up to 20 hectares, with percentages from 7 percent for estates from 10 to 20 hectares, up to 32 percent for estates of less than 0.5 hectares. Köpf (1999) found 
for five eastern German states 21 percent of the small-scale private forests, with a minimum of 19 percent in Thüringen and a maximum of 25 percent female ownership in Sachsen.

The current annual fellings account for $3.7 \mathrm{~m}^{3}$ per hectare, the potential usable availability is $5.7 \mathrm{~m}^{3}$ per hectare. This means that only about 70 percent of the felling potential is used, and that a high and sustainable potential for more working places exists. While in many parts of Germany the interest in "close-to-nature" forest management (which implements less activities in the forests, but more manual work) is growing, on the other hand the trend is (due to financial decisions) going towards less workforce in the sector, and more use of professional machinery.

Theoretically, any of the forest management systems is offering workplaces to men and equally to women, but in reality and by tradition the forest sector is male dominated. Information about forests as a working place is rare; it is even more difficult to find general updated gender disaggregated information.

Rural areas are faced with multiple challenges, such as structural changes, ageing of the population, drift to the cities from rural areas and loss of regional identities. It is regarded as important for the rural areas, for example, to improve their labour market situation and to take sustainable objectives more into account for rural areas. In addition, because of low profitability, organizations in both the public and in private forest sectors are restructuring and reducing the workforce.

\subsubsection{The current status of gender representations across organizations in Germany}

\section{General aspects in Germany - all sectors}

The percentage of women in working life in Western Germany in March 2006 was 59.3 percent (in France 69 percent, Sweden 70 percent) for all labour sectors (EUROSTAT, March 2006). Relatively more women than men have temporary contracts. According to the Shell-Study of Youth, 75 percent of young women would like to have families and paid work.

\section{Forest sector}

The German Federal Statistical Office provided data on female jobholders in the forestry sector. The office had access to the following two sources:

(1) The annual microcensus on population and job market: In May 2003, 40000 people worked in the forestry sector, 6000 of them were women (further categorization was not available, as given for men).

(2) Results from the Federal Agency for Work (Bundesanstalt für Arbeit - BA) concerned women with social security insurance (employees, excluding public officers and self-employed).

In 2004, of a total of 3713 civil servants and employee foresters (Beamte and Angestellte), 13.3 percent 
were women (tendency decreasing); in western German states 8.1 percent, and in eastern German states 22.8 percent. In 2004, of a total of 23318 forest workers 6.6 percent were female (tendency decreasing). Table 14 illustrates the statistics of the forest services numbers and proportions.

Table 14: Gender disaggregated data from state forest services from five exemplary states, 2002

\begin{tabular}{|c|c|c|c|c|c|c|c|c|c|}
\hline State & $\begin{array}{c}\text { Civil } \\
\text { servants } \\
(\mathrm{m}) \\
\text { (Beamte) }\end{array}$ & $\begin{array}{c}\text { Civil } \\
\text { servants } \\
(f) \\
\text { (Beamte) }\end{array}$ & $\%$ & $\begin{array}{c}\text { Employees } \\
\text { (m) } \\
\text { (Angest.) }\end{array}$ & $\begin{array}{c}\text { Employees } \\
\text { (f) } \\
\text { (Angest.) }\end{array}$ & $\%$ & $\begin{array}{l}\text { Workers } \\
\text { (m) }\end{array}$ & $\begin{array}{c}\text { Workers } \\
\text { (f) }\end{array}$ & $\%$ \\
\hline Brandenburg & 449 & 92 & 17 & 350 & 465 & 57 & 1.297 & 194 & 13 \\
\hline Lower Saxonia & \multicolumn{6}{|c|}{ (gender disaggregated data not available) } & 766 & 36 & 4 \\
\hline $\begin{array}{l}\text { North Rhine } \\
\text { Westphalia }\end{array}$ & 546 & 29 & 5 & 90 & 110 & 55 & 372 & 20 & 5 \\
\hline Saarland & 64 & 1 & 2 & 10 & 18 & 64 & 119 & 22 & 16 \\
\hline Thuringia & 452 & 94 & 17 & 166 & 203 & 55 & 913 & 27 & 3 \\
\hline
\end{tabular}

The number of women with jobs in forestry decreases constantly - as all jobs in forestry and timber industry, the absolute number of women decreases more rapidly than the number of employed men in the sector. This is mainly because there has been a high percentage of women in forestry in the former German Democratic Republic. After the reunification of Germany it has to be stated, that in the eastern Laender the loss of jobs affected women even more than men.

\section{Forest companies (including public) and wood processing industry}

Within the forestry and wood industry, Germany does not have sectorwide figures for employment. If data do exist, they are not gender specific. This implements corresponding problems for the external representation and the political perception of the sector.

Existing figures are verifying for the entire sector (according to European Union vocabulary "cluster forestry and timber") in Germany in 2003 about 700000 to 1 million jobs, with about 100 billion euro total revenue. Most of the small- and medium-sized enterprises are in the rural areas, where it is increasingly difficult to secure jobs.

\section{Forest workers}

In 1996, about 8 percent of the forest workers in state forest services were female (1 500), after 20 to 40 percent in the first half of the twentieth century - but those figures are referring to the numbers, not to the yearly working hours, which in the average always were lower for the female workers (Hoffmann, 1998a,b).

Since 2000, about 100 women are graduating as trained forest workers every year, the numbers of apprentices have been growing from 4 to 122 from 1984 to 1996. Their main reasons for this choice are 
their "interest in nature" and their preference "to work outdoor". Particularly the young trained female forest workers (21 to 30 years of age) have a strong interest in doing harvesting work. In 1988, 69 percent of female forest workers in GDR (east Germany) and 4 percent in FRG (west Germany) received formal training (Bock 2004, Hoffmann 1998a).

Female and male forest workers have different working profiles: only 0.8 percent of the women were working in harvesting (in 1996); about 50 percent of the female forest workers were mainly occupied with planting and other "typical/traditional female" work areas (Hoffmann 1998).

The box below shows, as an example, data from the German federal state Hessen:

\section{Forest workers in Land Hessen:}

The population census for Hessen from 1987 gave the figure of "3 191 forest workers" - not clearly defining the form of employment and area of work. The figure was probably higher due to double counting of work areas. A research study in 1994 tried to cover all forest workers - questionnaires were sent via the employers (forest authority, municipalities, private forest owners, accident prevention and insurance associations, contractors - forest authorities contacted about 2400 forest workers). Responses came back from 1150 forest workers, according to the following table:

$\begin{array}{lrrcc}\text { Employment/position } & \text { Total } & \text { Men } & \text { Women } & \text { Not specified } \\ \text { forest worker/state forest } & 690 & 656 & 33 & 1 \\ \text { forest worker } & & & & 2 \\ \text { municipal forest } & 310 & 299 & 9 & 0 \\ \text { Contract workers for private company } & 84 & 77 & 7 & 1 \\ \text { Independent contract worker } & 32 & 31 & 0 & 0 \\ \text { Contractor with permanent employees } & 12 & 12 & 0 & 0 \\ \text { Contractor with temporarily employees } & 6 & 6 & 0 & 0 \\ \text { Others } & 9 & 8 & 1 & \mathrm{X} \\ \text { Not specified } & 7 & 4 & 3 & 4 \\ \text { Total } & 1150 & 1093 & 53 & \end{array}$

(From Klaus Schriewer, 1995)

Though the table above is not representative, it reflects the underrepresentation of women in forest work.

\section{Forest authorities and the forest service}

The number of persons employed in forest authorities and forest service is decreasing constantly (budget constraints, rationalization of workflow, change of forest management, privatization of forests, work delegated to contractors, technical development). Higher positions (better income and decision-making positions) are occupied "traditionally" by far more by men than by women. The portion of women in higher positions in the forest administration is about 1 to 3 percent (forest officers, heads of forest departments). 


\section{University and research institutions}

The proportion of women in forestry colleges and universities is clearly increasing since the 1970s. In 2002 in forest colleges, 15 percent of the students were female, in universities 25 to 30 percent. Still, the chance to get an adequate job is low for all (Lewark, 2003). Theoretically, there is no real difference for men and women to work in research in the forest sector (and in forest management), but figures show that women are underrepresented (roughly never more than 30 percent). As a rule, it can be stated that the higher the career is, the lower is the percentage of women.

Germany has four universities with Faculties of Forestry (and related): Göttingen, Freiburg, Dresden/ Tharandt and (Munich) Weihenstephan. The traditional curricula of these faculties have been adapted to forestry in Germany. Due to increasing numbers of students and dwindling job opportunities in the "traditional" German forestry sector, the faculties have been broadening their fields of studies, including for example international forests and landscape management, tropical agroforestry.

Table 15: Number of students and proportion of women in the four universities with forestry study programs in Germany

\begin{tabular}{|c|c|c|c|c|c|c|c|c|c|c|c|c|c|c|c|}
\hline \multirow{2}{*}{$\begin{array}{l}\begin{array}{c}\text { University } \\
\text { year }\end{array} \\
\text { Faculty of } \\
\text { Forestry at } \\
\text { University of }\end{array}$} & \multicolumn{2}{|c|}{$\begin{array}{c}1997 / \\
1998 \\
\end{array}$} & \multicolumn{2}{|c|}{$\begin{array}{c}1998 / \\
1999 \\
\end{array}$} & \multicolumn{2}{|c|}{$\begin{array}{c}1999 / \\
2000 \\
\end{array}$} & \multicolumn{2}{|c|}{$\begin{array}{c}2000 / \\
2001 \\
\end{array}$} & \multicolumn{2}{|c|}{$\begin{array}{c}2001 / \\
2002 \\
\end{array}$} & \multicolumn{2}{|c|}{$\begin{array}{c}2002 / \\
2003 \\
\end{array}$} & \multicolumn{3}{|c|}{$\begin{array}{c}2004 / \\
2005 \\
\end{array}$} \\
\hline & 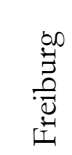 & 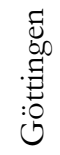 & $\begin{array}{l}\text { bo } \\
\vdots \\
\frac{7}{3} \\
\text { 辛 }\end{array}$ & 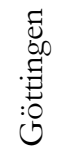 & 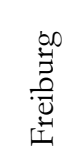 & 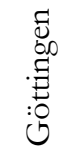 & 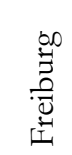 & 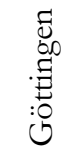 & 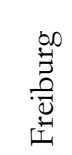 & 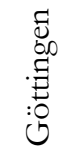 & 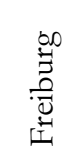 & 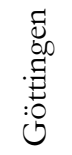 & 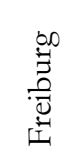 & 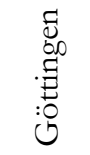 & 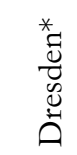 \\
\hline $\begin{array}{l}\text { Number } \\
\text { of forestry } \\
\text { students in } \\
\text { total }\end{array}$ & 565 & n.a. & 568 & n.a. & 610 & 629 & 650 & 590 & 614 & 578 & 704 & 623 & 662 & 680 & 789 \\
\hline $\begin{array}{l}\% \text { of women } \\
\text { of total } \\
\text { students in } \\
\text { forestry }\end{array}$ & 25.3 & n.a. & 29.2 & n.a. & 30.1 & 24.4 & 28.3 & 27.6 & 30.3 & 28.8 & 32.3 & 28.4 & 32.1 & 29.4 & 45 \\
\hline $\begin{array}{l}\text { Dipl. title* } \\
\text { awarded } \\
\text { by men and } \\
\text { women }\end{array}$ & n.a. & n.a. & 83 & n.a. & 89 & n.a. & n.a. & n.a. & n.a. & n.a. & 66 & n.a. & n.a. & n.a. & $138^{*}$ \\
\hline $\begin{array}{l}\text { \% of women } \\
\text { who got } \\
\text { Diploma title }\end{array}$ & n.a. & n.a. & 24 & n.a. & 23.5 & n.a. & n.a. & n.a. & n.a. & n.a. & 25 & n.a. & n.a. & n.a. & $43 *$ \\
\hline $\begin{array}{l}\text { Ph.D. title } \\
\text { awarded } \\
\text { by men and } \\
\text { women }\end{array}$ & 32 & 30 & 30 & 28 & 16 & 13 & 24 & 32 & 25 & 6 & 25 & n.a. & n.a. & n.a. & n.a. \\
\hline $\begin{array}{l}\text { \% of women } \\
\text { awarded } \\
\text { Ph.D. }\end{array}$ & 28 & 16 & 20 & 18 & 12 & 15 & 25 & 12.5 & 36 & 17 & 12 & n.a. & n.a. & n.a. & n.a. \\
\hline
\end{tabular}

* University of Dresden/Tharandt: titles awarded in forestry programs: master, bachelor and diploma for forestry, master of tropical forestry and diploma for environmental studies. 


\section{Additional information for comparisons:}

At the University of Göttingen over all faculties, an average of about 50 percent of all students are female. (All Göttingen-related data received from Dr Edit Kirsch-Auwärter, Universitätsfrauenbeauftragte Georg-August-Universität, Göttingen in 2004.) Göttingen changed to bachelor and master programmes in forestry starting in 1998.

Since 1999, the Faculty of Forestry at the University of Freiburg, in addition to the diploma programme, offers the international study programme "Sustainable Forestry and Land Use Management". About 30 students start their studies each year, the relation between male and female students is more balanced than in the "traditional" programme "forestry sciences" (Source: http://www.verwaltung.uni-freiburg.de/statdaten/). Data from the Faculty of Forestry at the University of Munich/Weihenstephan were not accessible during the time of our research in 2004.

Summarizing, it can be stated that there is a serious gap in reality and in statistical data material about women representation in the forestry sector. There are almost no figures available about gender distribution among forest owners and among hunters. The number of trained female forest workers is marginal. The number of women decreases with the career level of job position - but only in forest education, not in the actual positions. Figures for forestry are often mixed with statistical data about the agricultural sector - they do not differ much related to the position of women ("Frauen in Forst-und Landwirtschaft", Statistisches Bundesamt Wiesbaden, 2004).

\subsubsection{Why is the gender representation the way it is in Germany's forestry sector?}

Even if there are almost no clear statistics showing gender disaggregated figures, it is obvious that women are poorly represented. Reasons for this are different, depending on the point of view such as ownership, timber industry, education, research.

For the sector of forestry (including hunting and wood industry), probably most of the time the physically hard work, outside of the controlled area of family and house, was traditionally regarded as a "male domain".

Because networks of men (supporting and promoting each other) have existed a long time and work well, it is difficult for women to enter the job market. Especially since the available jobs in this area are decreasing, it is difficult for women (or any other newcomer) to have access to rare jobs, even though the above-mentioned traditions are less important and less powerful control instruments today.

This is probably similar to jobs in the area of forestry research (universities). Even though the numbers 
of female students, Ph.D. students, teachers, professors are growing, the number of women in decision-making positions is relatively smaller than of men (compared to students' ratio).

The motivation and the demands of women are - perhaps - different from those of men: it seems that women are easier satisfied and settled with jobs, salaries, and working conditions - or just less willing or ready to fight for their dreams and incomes. Probably some of the women are too occupied with their family situation (education of children/no free kindergarten/other constraints) to pursue their own careers.

There are several means to improve this situation in Germany:

- raising awareness within the different state forest services and forest companies for gender issues;

- launching of a federal gender mainstreaming programme in the forest sector, including female forest ownership;

- collecting gender-sensitive data for the forestry sector at the federal level (responsible: federal ministry with the support of regional Laender ministries);

- actions to encourage female forest owners to take part in training courses;

- information and education from childhood about the potential opportunities in the forest sector;

- motivation for schoolgirls: showing "living examples of role models" in careers;

- respect of the principle "same salaries for same work";

- same appreciation of work from men and from women;

- enabling women who raise children to paid work and follow their careers; and

- providing networks for women in the sector to give access to information, exchange of experiences, for motivation e.g.

\subsection{ITALY}

By Laura Secco and Laura Peruch, Department of Land Use and Agro-Forestry Systems

(Department of TESAF), University of Padova - Italy

\section{Abstract}

On the basis of the available official data and of a preliminary ad hoc survey conducted in 2003 at national level, the paper presents the situation women are facing in the forestry sector in Italy in terms of number, employment conditions and perspectives for the future. The main problems - lower wages, low participation in decision-making and in power positions, preconceptions, etc. - are common to those outlined by specific studies or initiatives carried out in other countries (Croatia, France, Norway, Sweden, Switzerland, among 
others). However, in the near future, Italian women are expected to enter forestry professions at all levels in increasing numbers, acting as forestry workers, private and public forest companies' managers, experts and technical advisers, officers and agents of the paramilitary State Forestry Corp (Corpo Forestale dello Stato), and to demand their role, specific contribution and attitude to be more recognized. Social as well as forestry policies and strategies have to take into account this issue, which is part of broader changes throughout the forestry sector.

\subsubsection{Introduction}

In Europe, the primary sector is included among the ten fields of work characterized by the higher disparity between men and women, where men are clearly prevailing (CE, 2000) and the role of women is underestimated or not even identified - also because specific statistical data and information on gender issues in agriculture and forestry sectors are lacking. Nevertheless, this situation reflects a more general one: according to data from the Ministry of Labour in Italy, even though 52.2 percent of public employees in 2003 are women, they only hold 4 percent of top management positions in public companies and 4.9 percent in private enterprises.

In Italy, as well as in other developed countries, forestry is still a "masculine universe": only a very limited number of women are directly employed in forestry operations in the field, although in several contexts women are more and more reaching higher qualification levels - bachelor degrees, master's and Ph.D. - in this field of study. Until a few years ago, the preconception that this kind of job was ill-suited for women was still in force, both among professional and academic foresters. This is proved by sentences such as "Field operations carried out in coppices by women, young people or unqualified forestry workers can negatively influence coppice forests' productivity and facilitate degradation phenomena" (Cappelli, 1991), as reported in a well-known Italian textbook on forestry. Presently, and fortunately, change signals can be identified.

The present paper is intended to present the condition of women in the forestry sector in Italy, in terms of number, employment conditions and opportunities, current problems and future perspectives. It includes two main parts: the first analyses the few official data that are currently available on gender and forestry at the national level; the second one presents the results of a preliminary, empirical survey carried out in 2003 in the department of TESAF of the University of Padova.

\subsubsection{Official data on women in the primary sector in Italy}

In Italy, as well as in other European countries, forestry is only a secondary branch of agriculture. A branch in which the discrepancies between women and men are even more relevant than in the sole agricultural 
sector, but where the informational level in terms of quantity and quality of statistical data are very low or even unexisting. In general, at national level, the data and information available on forestry works and workers are less detailed and comprehensive with respect to those available on other forestry issues, such as forested areas, forest fires, phytosanitary conditions, harvested wood. The Italian National Statistical Institute (ISTAT) does not provide disaggregated data about forestry workers employed by public authorities, private enterprises, or logging companies. With such a limited informative background, it is straightforward to understand how difficult it might be to collect and analyse even very simple and basic data on women involved in forest activities in Italy. Only few data are available from different official sources of information, as described in the following section.

\section{ISTAT data}

According to EUROSTAT data (2004), women who are employed in the primary sector account for 4.4 percent of the total amount of employees in Italy. Women represented about 30 percent of top-level management in Italian agricultural firms in 2002 (Di Gregorio and Licari, 2005). According to ISTAT, women with occupations on farms or in forestry organizations amounted to 32.2 percent of the total number of employees within the primary sector in 2003 (Figure 3).

Figure 3: Employees within the primary sector in Italy, by gender (\%)

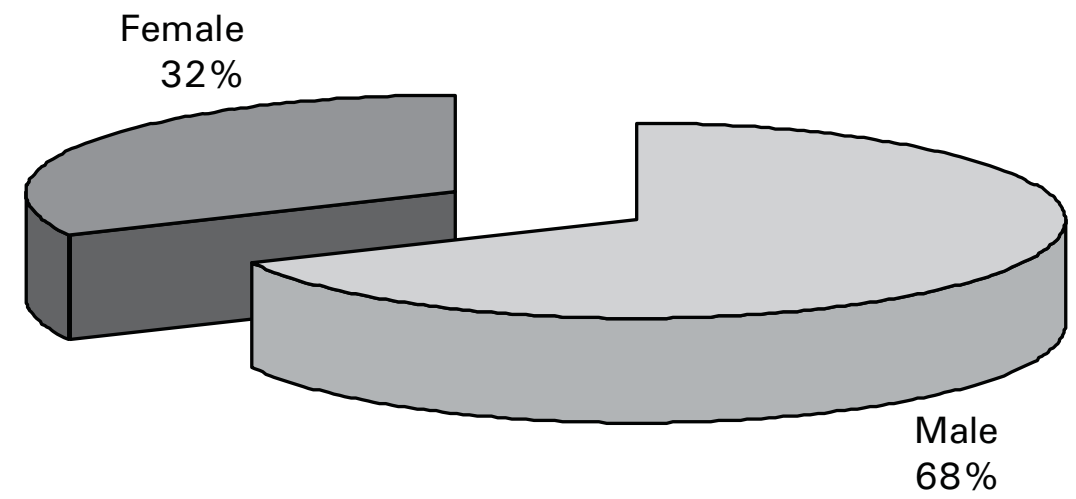

The data of the Italian General Agricultural Census

Within the time series of data reported by the Agricultural General Census carried out every ten years between the years 1861 and 1981 in Italy, the number of forestry employees (women and men) at national level is always very limited in statistical terms (Giungi, Zanzi Sulli, 1993). After 1981, in the ten-year Italian Agricultural General Census updating, employment definitions and classifications changed, thus making it impossible to identify disaggregated data specifically on forestry workers - they have been included in the broader category of agriculture and fisheries. As a consequence, the data can hardly be interpreted on the basis of common statistical 
parameters. Women working in forestry have been recorded by all mentioned census (Figure 4), with figures oscillating down to a minimum of 400 units in 1971, up to maximum of 9000 units in 1931. With respect to the male universe, which varies between a minimum of 20000 units to a maximum of 90000 , women in forestry have always represented a very limited percentage, never higher than 12 percent (Figure 5).

Analyzing the data both on women and men in the long period (Figure 4), it is meaningful to note two trends: (i) women are increasing while men are decreasing, which means that women substitute men in forestry when they move to other regions or occupational sectors; and (ii) when a growing demand for forest management has given higher employment opportunities the number of both women and men increased, thus showing that women's work was integrating and supporting men's work.

Figure 4: Employees in the forestry sector ( $\%$ on the total number of employees in the primary sector)

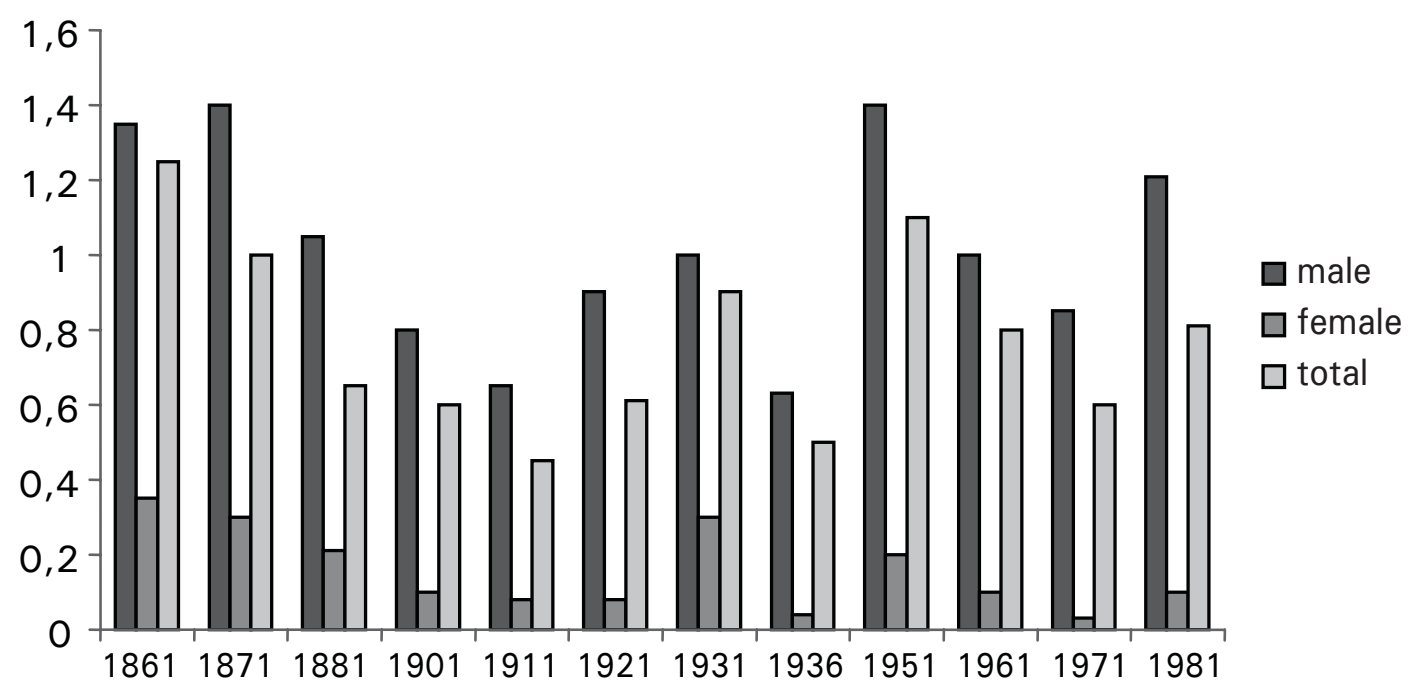

Source: the Italian General Agricultural Census.

Figure 5: Women employed in forestry ( $\%$ on the total number of employees in the forestry sector)

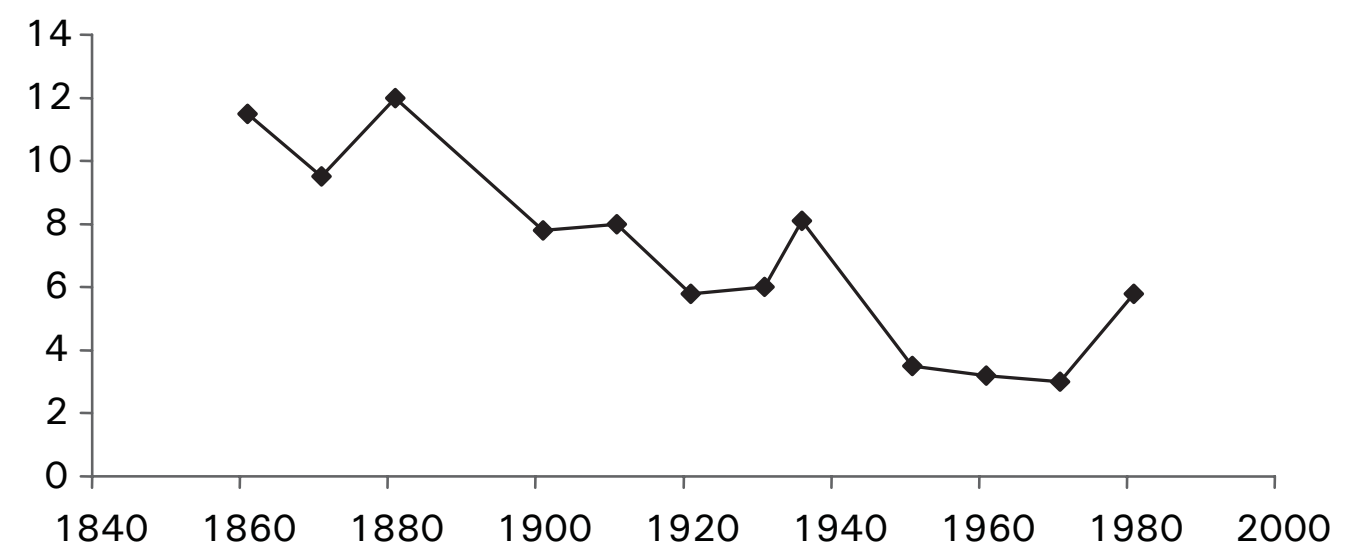

Source: the Italian General Agricultural Census. 


\section{The paramilitary State Forestry Corp data}

Within the paramilitary State Forestry Corp (CFS), with competencies in forests and environment, especially since 1992, women have recorded a constantly growing number in various occupational roles (at the beginning, only among technical and administrative staff than among forest rangers, and more recently also among officers). It has to be mentioned that in 1992 when the first female forest rangers were employed, women comprised about 3 percent of the CFS staff (Colletti, 1998).

In 1996, women were primarily engaged in the technical and administrative staff, representing 20 percent of its staff. Among officers, women accounted for 10.8 percent, while among forest rangers only 4.1 percent (Colletti, 1998). In 1996, not one woman held a top-management position within the CFS. It is worthwhile to mention that one year later, in 1997, the number of women had grown to +1.5 percent on average (Table 16). Nevertheless, males were (and still are) maintaining their predominance (Figure 6).

Table 16: Women employed, by occupation, by CFS (1996-1997)

\begin{tabular}{|c|c|c|c|c|}
\hline \multirow[b]{2}{*}{ Occupation } & \multicolumn{2}{|c|}{1996} & \multicolumn{2}{|c|}{1997} \\
\hline & Number & $\%$ & Number & $\%$ \\
\hline Officers & 64 & 10.8 & 66 & 11.1 \\
\hline Forest rangers & 254 & 4.1 & 378 & 6.0 \\
\hline Technical and administrative staff & 114 & 20.0 & 109 & 19.5 \\
\hline
\end{tabular}

Source: Colletti, 1998.

Figure 6: Men and women employed by the CFS (1997)

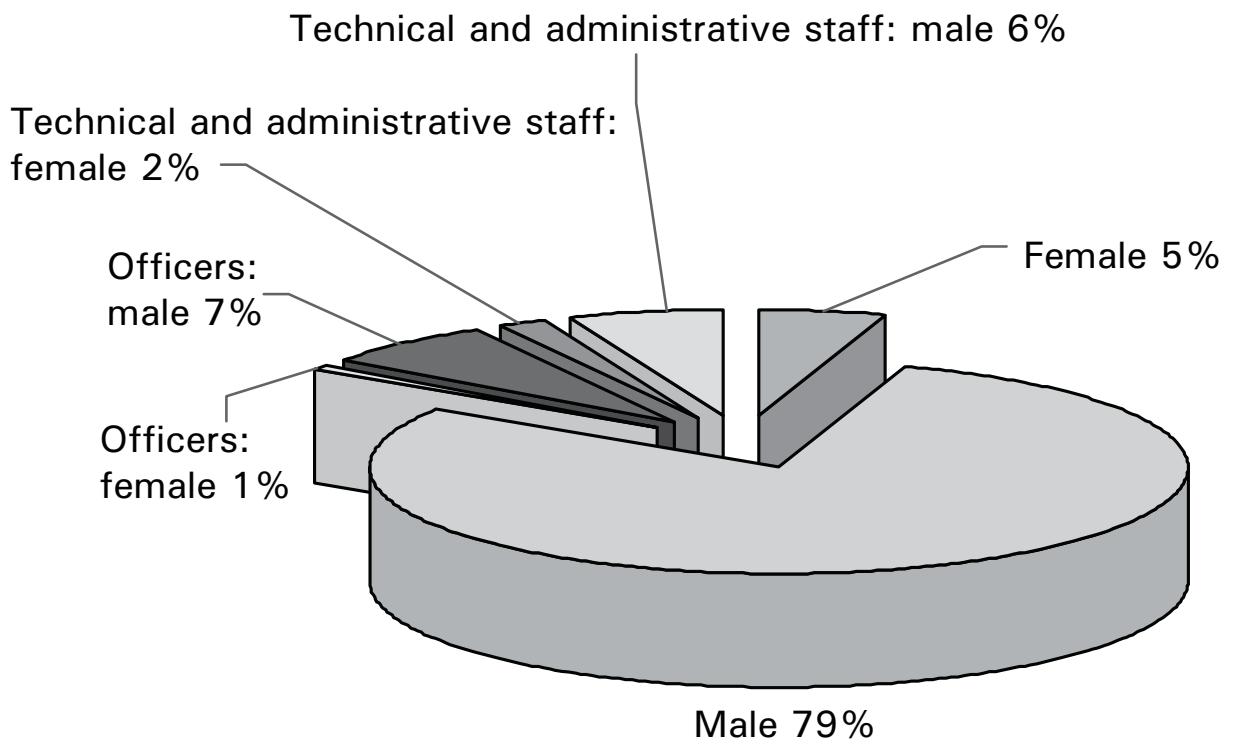

At present, a specific Committee for Equal Opportunities has been created within the CFS (General Director Decree, 15 March 1996, according to art. 20 DPR 31 July 1995). Women in the CFS staff are no longer unusual: they are engaged with the same procedures and rules with respect to their male colleagues, they 
are enrolled in the same professional training activities and they are working with the same occupational roles, both at operational and administrative levels. New data should be collected from CFS for proper updating, but they are not directly available through public statistics.

\section{Education and qualification}

With regard to education, according to the Ministry of University and Scientific Research and to two well-known tertiary colleges dealing with agriculture and forestry in Friuli Venezia Giulia and Veneto regions (northern Italy), several young women decided to undertake forestry studies only after finishing high school. This seems to be due to two main reasons, strictly connected with the specific national context: first of all, in Italy the tertiary colleges that provide highly qualified professional skills in forestry after primary school are almost completely lacking, while there are 13 universities that have a Master of Science or Bachelor-level courses in the field of forestry; secondly, there is a socio-cultural feature to be considered: the family strongly influences a young woman's choice in terms of education and career - at 14 years old it is unlikely that young women have already reached a well-defined vocation in forestry.

From 1982 to 2001, 165 specialized forestry workers received their professional qualification at the Forestry Tertiary College of Paluzza in Friuli Venezia Giulia region, of which only 5.5 percent were female. In the last six to eight years, the number of qualified women at one of the two mentioned tertiary colleges in northern Italy have been less than three per year on average. Table 17 presents the women who are educated in forestry at the university level.

Table 17: Women graduates at Italian universities

(Bachelor of Science or Master of Science degrees in forestry)

\begin{tabular}{cccc}
\hline \multirow{2}{*}{ Year } & Graduates & \multicolumn{2}{c}{ Women graduates } \\
\cline { 3 - 4 } & & Number & \% \\
\hline 1998 & 235 & 70 & 29.8 \\
\hline 1999 & n.a. & n.a. & n.a. \\
\hline 2000 & 273 & 94 & 34.4 \\
\hline 2001 & 446 & 171 & 38.34 \\
\hline
\end{tabular}

Note: n.a. $=$ not available

Source: Murst, 2003

According to the official registry of self-employed persons working in the agriculture and forestry sectors (Brunori, 2003), women made up only 13.7 percent of the total in 2003; the percentage of women among those who are less than 34 years old is about 24 percent, while the percentage among those who are more than 40 years old decreased to 14.4 percent (Table 18). (In Italy, graduates in agriculture or forestry sciences are 
allowed to be included in the registry - maintained at the local and national level - after graduating, passing a specific examination and paying the annual admission fee.) The higher percentage of women working in forestry has been recorded in the northwestern regions of the country, at 16.9 percent, and a lower percentage in southern Italy and the islands, at 11.9 percent (Table 19). This discrepancy is strictly connected to Italy's historical background and local socio-cultural and economic conditions between "the north and the south", which have had significant gaps on different issues as well (including educational level and employment opportunities in forestry).

Table 18: Self-employed graduates in agriculture and forestry, by age and gender (2003)

\begin{tabular}{lrrrrrrrrrr}
\hline & \multicolumn{1}{c}{ Age (\%) } \\
\cline { 2 - 12 } Gender & $<\mathbf{3 4} \mathbf{y}$ & $\mathbf{3 5 - 3 9}$ & $\mathbf{4 0 - 4 5}$ & $\mathbf{4 6 - 4 9}$ & $\mathbf{5 0 - 5 4}$ & $\mathbf{5 5 - 5 9}$ & $\mathbf{6 0 - 6 4}$ & $>\mathbf{6 5}$ & Total \\
\hline Male & 76.1 & 79.7 & 85.6 & 94.5 & 98 & 98.7 & 98.9 & 97.8 & 86.3 \\
\hline Female & 23.9 & 20.3 & 14.4 & 5.5 & 2 & 1.3 & 1.1 & 2.2 & 13.7 \\
\hline
\end{tabular}

Source: Official registry of self-employed persons.

Table 19: Self-employed graduates in agriculture and forestry, by geographical distribution and gender (2003)

\begin{tabular}{lcccc}
\hline & \multicolumn{4}{c}{ Geographical distribution in Italy } \\
\cline { 2 - 5 } Gender & $\begin{array}{c}\text { Northwest regions } \\
\mathbf{( \% )}\end{array}$ & $\begin{array}{c}\text { Northeast regions } \\
\mathbf{( \% )}\end{array}$ & $\begin{array}{c}\text { Centre regions } \\
\mathbf{( \% )}\end{array}$ & $\begin{array}{c}\text { South regions } \\
\text { and islands } \\
\mathbf{( \% )}\end{array}$ \\
\hline Male & 83.1 & 86.9 & 82.8 & 88.1 \\
\hline Female & 16.9 & 13.1 & 17.2 & 11.9 \\
\hline
\end{tabular}

Source: Official registry of self-employed persons.

\section{Employment opportunities for women graduates in forestry}

In 1999, a study was carried out by CENSIS, taking into consideration the 42 women who graduated in forestry in 1992. Although the data are limited and although the results cannot be considered statistically representative of the national situation, it is worthwhile to briefly comment on them. According to the study, three years after graduation about 38 percent of women forestry students had found permanent employment while 42 percent found temporary positions. Some 8 percent of them were already employed before finishing their studies. This means that about 88 percent of women graduates found work quickly; in any case, the figure is considered the highest (+27 percent) with respect to all the other sectors in which women graduate. When compared with male colleagues, women have found it easier finding a job after graduating (Table 20). 
Table 20: Forestry graduates employed three years after graduating, by gender and type of job (permanent or temporary)*

\begin{tabular}{lccc}
\hline Gender & $\begin{array}{c}\text { Permanent job } \\
\mathbf{( \% )}\end{array}$ & $\begin{array}{c}\text { Temporary job } \\
(\mathbf{\%})\end{array}$ & $\begin{array}{c}\text { Employed before graduating } \\
\mathbf{( \% )}\end{array}$ \\
\hline Female & 38.0 & 42.1 & 7.9 \\
\hline Male & 30.5 & 31.0 & 10.2 \\
\hline
\end{tabular}

*1992 data.

Source: CENSIS, 1999.

According to CENSIS, about 43.3 percent of women who graduated with forestry degrees in 1992 were employed in 1999 as freelancers; 28.6 percent of them were self-employed or entrepreneurs; the remaining 17.6 percent were included in the non-specified category of "Other". None of the women employed by companies or other organizations held a managerial position; about 32.2 percent of them were employed as school teachers (the percentage in 1992 was considerably higher than the 23.7 percent recorded for total women university graduates in Italy). Finally, in 1992 about 14 percent of forestry women graduates were public workers, but only 3.2 percent of them were employed as public officials and 5.4 percent in "Other jobs".

The aforementioned data should be considered out of date, as in recent years structural and significant changes within the forestry labour market have taken place in Italy and Europe. Among the driving forces, it is worthwhile to mention, at least: the globalization process, the European common agricultural policy and rural development (which have assigned a growing role to forestry and to the protection of environment); the decreasing role with direct management responsibilities of governments and other public authorities into the forestry sector; the growing demand for more environmentally friendly and natural products and services; and the organizational arrangements carried out by industries, businesses and enterprises to fit in more flexible working structures (Lewark et al., 2000). New occupational opportunities for qualified forestry workers and professionals have emerged as a consequence of an increasing demand for protected areas, urban greenery and forests, and wooden biomasses for energy production, among other things.

In the past, forestry graduates were usually employed by public forestry authorities (first by the paramilitary CFS, and more recently by the Forestry Services of the regions). Presently, though, as a consequence of the aforementioned phenomena, young foresters are dealing with new kinds of jobs and fields of work. In order to have an idea of the trends in the recent past, Table 21 presents employment changes for graduates in the Forestry Sciences at the University of Padova in two periods: 1985-1989 and 1990-1995 (Defrancesco, 1997). 
Table 21: Changes in employment for graduates in Forestry Sciences, University of Padova

\begin{tabular}{|c|c|c|}
\hline Employment type & $\begin{array}{c}1985-1989 \\
(\%)\end{array}$ & $\begin{array}{c}1990-1995 \\
(\%)\end{array}$ \\
\hline Employed by local public authorities & 28 & 5 \\
\hline Employed by national public authorities & 5 & 3 \\
\hline Teachers & 15 & 12 \\
\hline Self-employed & 28 & 12 \\
\hline Other job & 24 & 55 \\
\hline Not employed & 0 & 13 \\
\hline
\end{tabular}

Source: Defrancesco, 1997.

With regard to women's employment opportunities in a general occupational context, even if specific quantitative data are lacking there is reason to believe that women are mainly employed in jobs more related to environmental protection, environmental education, rural development, urban forestry than in jobs more strictly related to traditional forest management activities.

\subsubsection{Results of a preliminary ad hoc survey in Italy}

A preliminary survey on the condition of women in forestry in Italy was carried out in 2003 at the Department of Land and Agro-Forestry Systems at the University of Padova. Questionnaires were sent to 48 forestry workers ( 45 women and $3 \mathrm{men}$ ) selected from a broad range of roles and occupational categories. They include: 27 employees in public forestry authorities; 3 self-employed women; 3 women employed as forestry workers in the field; 2 women managers in harvesting companies; 9 researchers employed by the university; and 3 women employed by a forest owner's association. The questionnaires drew a 62.5 percent response rate. In addition, 5 direct interviews were carried out, focusing on the women involved in field forestry works.

Based on the questionnaires, data have been collected on the number of women employed by some public forestry authorities in four Italian regions and on their occupational roles and hierarchical positions (as workers, officials or managers), see Tables 22 and 23.

Table 22: Forestry workers employed by public forestry authorities, by gender

\begin{tabular}{lrrr}
\hline Public forestry authority & Male & Female & Female (\%) \\
\hline Veneto region forestry services (north Italy) & 623 & 15 & 2.4 \\
\hline Trentino Alto-Adige region forestry services (north Italy) & 15 & 5 & 25.0 \\
\hline Sardinia region forestry services (island) & 4.067 & 566 & 12.22 \\
\hline Basilicata region forestry services (south Italy) & 1.331 & 2.738 & 70.8 \\
\hline
\end{tabular}


Table 23: Public officials and managers employed by public forestry authorities, by gender

\begin{tabular}{lccc}
\hline Public forestry authority & Male & Female & Female (\%) \\
\hline Veneto region forestry services (north Italy) & 70 & 13 & 15.6 \\
\hline Trentino Alto-Adige region forestry services (north Italy) & 40 & 4 & 10.0 \\
\hline Sardinia region forestry services (island) & 39 & 10 & 20.41 \\
\hline Basilicata region forestry services (south Italy) & 19 & 4 & 17.4 \\
\hline
\end{tabular}

It is worthwhile to mention that the percentage of women employed as forestry workers by public forestry authorities is significantly higher in Basilicata, a region in southern Italy. This is mainly due to the strategic role historically assigned by local southern governments to forestry employments. Occupational opportunities have always been provided in this sector by local politicians, both for welfare and political power reasons. Field activities for forest and environment management, fire prevention, soil erosion control, for example, provide thousands of jobs for unqualified people, in regions where the unemployment rates have always been very high, especially for women. With regard to officials and managers, the percentage of women among them is more consistent among the investigated regions, both in the south and in the north of Italy.

According to the questionnaire's results, women are actually precluded from some specific tasks that are considered to be traditionally masculine such as, for example, those carried out by forestry workers who use chainsaws during timber harvesting operations. The "lack of force, physical energy and hardiness" is considered by those who were interviewed to be the main reason for gender differences among forestry workers, while the "maternity" and the "lack of expert and well-motivated women" are considered to be the reasons in setting gender differences among males and females engaged in advanced tasks and higher responsibilities (officials and managers), both in the case of public employers and self-employments.

Finally, and significantly, about 13 percent of women included in the sample were aware of denunciations of labour injustices and cases of abuse. If compared with the figure reported at national level (4 to 6 percent of the workforce experienced discrimination at the workplace), (Giglioli and Harald, 1999), the percentage is significantly higher.

According to interview results, the interviewed women engaged as forestry workers and entrepreneurs emphasized that actual forestry work does not require special "physical requirements". They believe that women are being prevented from taking part in these activities because of close-mindedness and routine reasons rather than for real physical ability or other kinds of limitations. Such situations are now changing, even in Italy: increasingly, women are being accepted and recognized as professionally qualified and well-prepared to deal with their forestry tasks, both by their male colleagues and by officers.

Women do not perceive using technical equipment (trucks, tractors, chainsaws, etc.) in forestry sites 
during logging activities as a problem. In addition, with respect to their male colleagues, the interviewed women believe that women are more careful concerning special tasks (in burning felling waste, for example, they declare to pay more attention to avoid damaging the trees around them than their male colleagues). It is worthwhile to mention that some of the interviewed women love their job, and are very satisfied, especially because it allows them to spend their working day in open spaces, in wild nature, and not in an office.

\subsubsection{Final considerations for Italy}

According to this preliminary, but only partial survey carried out in 2003, women in the forestry sector in Italy are still a narrow minority. Their number is even smaller when considering the less qualified occupational roles and employments. The lack of well-motivated and professionally qualified women is considered to be one of the key factors influencing inequalities among males and females based on gender issues in the forestry sector.

A reversal process, however, has begun: the number of women who receive a graduate degree in Forestry Sciences is increasingly growing, as well as the number of women who are entering the paramilitary CFS. In addition, structural (and cultural) changes are affecting the Italian forest labour market and forestry sector, as a consequence of the growing awareness of environmental and social problems, the growing demand for new forest products (non-timber forest products, organic wild products, etc.) and services (carbon sequestration, landscape protection, biodiversity conservation, quality water supply, employment opportunities for rural people, etc.). This is creating new, differentiated niches in the labour market, where women can properly place themselves. Nevertheless, past experiences have shown that this process will not spontaneously proceed. Strong commitment is needed both by women and by key decision makers (FAO/ECE/ILO, 2001) in order to improve the organizational framework, by introducing more transparent rules on selecting employees and advancement procedures, setting proper services to family (welfare), providing part-time positions (also at the top-management level), and improving women's access to training and education programmes, among other things.

On the other side, cultural and mentality improvements are needed so that women's positive role in the natural and forest resources management sectors can be recognized. Such a role is connected, among others, to their particular behaviours and attitudes (communication ability, capacity to adopt participatory approaches in conflict management, aptitude in facing problems, and adopting non-conventional approaches).

Further research, however, is needed in order to systematically collect data on women in forestry in Italy not only for updating the informative framework (most of the official data actually available are quite outdated) and for addressing specific policies and strategies to promote equal opportunity and to avoid discrimination, but also for giving women higher credit into the forestry sector. 


\subsection{Norway}

By Berit Sanness

\subsubsection{General aspects of the forestry sector in Norway}

Characteristics of Norway's forestry sector are:

Total forest area: 12 million hectares

Annual growth: 22.5 million $\mathrm{m}^{3}$

Annual felling (excluding fuelwood and natural dead trees): 7.5 million $\mathrm{m}^{3}$

Standing volume (more than doubled in 100 years): 660 million $\mathrm{m}^{3}$

Within the past 20 years, timber prices have dropped substantially while costs of forest operations have increased. These factors and others have contributed to increasing mechanization in forestry operations and to restructuring the forestry sector. Private forest owners have also been affected as their work has dramatically decreased. In 2003, entrepreneurs with exclusively mechanized harvesting machines carried out 85 percent of the harvesting in Norway (Norwegian Statistics, 2004).

In addition, the number of employees in forest owners' organizations has declined about 25 percent in the last ten years, with further reductions expected. Although the number of forest officers within the Forestry Service is the same as 20 years ago, the work focus has changed for many of them and they now spend less time dealing with forestry matters.

\subsubsection{Gender representation across organizations in Norway}

\section{The Norwegian Forestry Service}

In 1986, 435 people were employed in Norway's Forestry Service. The Forestry Service continues to be stable in terms of the number of people it staffs, as in January 2006 the company employed 425 people; however, although the share of women in forestry positions has increased, it is still very low because currently women hold only 11 percent of forestry positions (see Table 24).

Table 24: Share of women in forestry positions in the Norwegian Forestry Service, 1986-2006

\begin{tabular}{|c|c|c|c|c|c|}
\hline & 2006 & 2001 & 1996 & $1991 *$ & 1986 \\
\hline National level, forestry section & $27 \%$ & $25 \%$ & $26 \%$ & $6 \%$ & $0 \%$ \\
\hline County level & $15 \%$ & $11 \%$ & $4 \%$ & $2 \%$ & $1 \%$ \\
\hline Municipality level & $10 \%$ & $8 \%$ & $5 \%$ & $2 \%$ & $1 \%$ \\
\hline Total, on average & $11 \%$ & $9 \%$ & $7 \%$ & $3 \%$ & $1 \%$ \\
\hline
\end{tabular}

*Estimated.

Source: The Norwegian Forestry Society, 1986 to 2006. 


\section{The State Forest and Land Corporation (Statskog SF)}

Statskog SF is a state-owned commercial company, holding about one-third of the country's total land area (including 10 percent of Norway's forest area). At present, forestry represents approximately 50 percent of the company's economy. Since 1995, Statskog SF has met the 40 percent requirement concerning gender balance among board members. In addition, since 2001 a woman has held the position as chairperson, and in 2005 the first woman employee of the company was elected a member of the board of directors.

A man has always held the managing director position at Statskog. Furthermore, between 1993 and 2006, Statskog SF did not have women forest officers on its staff. Although the gender aspect has been a matter of concern since 1993, gender initiatives have not been introduced as fewer people are needed within the forestry sector of the company (Strøm, 2006).

\section{The Norwegian Forestry Society}

The Norwegian Forestry Society and its 20 county-level societies are non-governmental organizations providing information on forests and forestry. While 20 years ago these organizations were fully dominated by men, today the situation has changed to some extent. For one thing, the county organizations have a better gender balance among employees than economic forestry organizations, as 25 percent of their information officers are female forest graduates, the first of them employed in 1990. In 1988, the first woman was elected to be a member on the board of directors at the Norwegian Forestry Society and served as its chairperson from 1994 to 2000. By 2005, half of the board members were women. At county level, the first women chairpersons were elected in 1992 and by 2005, 5 percent of board chairpersons in county associations were women (the Norwegian Forestry Society, 2005).

\section{The Forest Extension Service}

The Forestry Extension Service is a non-governmental organization providing education and training in forestry matters as well as raising public awareness regarding the importance of forestry. It achieves its goals by producing educational materials, consulting services and organizing conferences. The organization also offers forestry courses, such as the "Active Forestry" course programme, with forest owners being the main target group.

In 1988, the owners of the Forest Extension Service elected the first woman as a board member. The number of women on the board increased and was 43 percent in the period from 1998 to 2001, but at present the percentage stands at 29 percent. The chairpersons and the board members who represent the employees (since 1992) have always been males. In 2005, the share of women at the general assembly was 18 percent (the Forestry Extension Service, 2006). 
Furthermore, a man has always held the managing director position at the organization. The number of employees has remained at nearly the same level for 11 years, while the number of women has increased from 33 to 43 percent since 1995. Up to this day, no woman has been part of the leader team.

Women as a target group with increasing importance were mentioned for the first time in the strategic plan for the Forest Extension Service 1993-1996. Presently, various activities are in place to meet female forest owners' needs, including surveys and training courses carried out by the company in cooperation with Viken Skog BA, the largest forest owners' district association.

\section{The "Active Forestry" course programme}

In the late 1980s, “Women in Forestry” focused predominantly on gender aspects of the organization's programme. At the same time, the government provided political support by claiming that the institute's "Active Forestry" course programme needed to be adjusted and promoted in order to achieve a higher share of female participants. A study by Ove Ericsson demonstrated that the illustrations in the institute's publications did not contribute to improved gender balance (Ericsson, 1987). A new project, initiated by Women in Forestry, was carried out at the institute between 1992 and 1995. The main objective was to attract women so that they would be actively engaged in forest operations and forest management.

Actions were tested in four trial counties. A new course was developed and women teachers were educated, as women preferred female instructors. The first one graduated in 1989. The project concluded that to get a higher share of women in forestry, contributions from the entire forestry sector would be required (Lindstad, 1995).

Initially, the "Active Forestry" programme covered courses in practical forestry issues. Recently, more courses are being offered on competence building for forest owners as decision makers. The number of female participants amounts to 10 percent, despite the fact that in 2005 the total number of participants in "Active Forestry" courses decreased to approximately 1900 ; this is a 50 percent decline when compared with 1986's enrolment. Consequently, only half of the teachers employed in the 1990s are still employed today, 5 percent of them women (Lindstad, 1995; the Norwegian Forest Extension Institute, 2006). In cooperation with Viken Skog BA, a special introduction programme targeted at female forest owners has been tested recently.

Surprisingly enough, the Forestry Extension Institute does not seem to have implemented gender balance in its publishing policy so far. Only 11 percent of the pictures that include people in the "Active Forestry" books of today, show women, 72 percent show men, while 17 percent include both sexes. 


\section{The Norwegian Forest Research Institute}

The Norwegian Forest Research Institute is the most important research institute on forestry matters in Norway. Until now, the institute has not conducted any research concerning gender structure.

Because the institute is owned by the state, the board of directors is appointed by the Ministry of Agriculture; therefore, the institute has met the demands of having 40 percent women on its board for many years. So far, only men have been chairpersons and managing directors. A woman has not been a member of the research institute's "leading team" exept for during 1999-2001. In 2004, the gender balance of the 103 employees was:
Leading team:
$0 \%$ women
Researchers:
$26 \%$ women
Technical assistants:
$41 \%$ women
Secretaries:
$100 \%$ women
Technical support, cleaning:
$83 \%$ women
Total:
$35 \%$ women

(The Norwegian Forest Research Institute, 2005)

Common with other companies, the salaries at the institute tend to be higher for men as ten of them have the highest salaries. The average salary for women was lower than the average salary for men in each of the groups. Moreover, the average salary for women researchers was about 11 percent lower than that of their male colleagues.

The Norwegian Research Institute aims to improve equal rights between the sexes within the different categories of employment and aspires to reach gender balance. Its action plan for gender balance provides economic support for women employees who enrol in competence-building courses, and encourages women to participate in mentor programmes to increase the number of women within the leader team in 2006. In addition, the institute has made a commitment to proclaim all vacant positions as gender neutral (Ibid).

\subsubsection{Gender structure within forestry education}

\section{University level}

In Norway, the first woman graduated as forester (candidate agriculture) in the Faculty of Forestry at the University of Agriculture in 1964. More than ten years later, a second woman graduated, with the tenth woman graduating in 1984. Until 1985, only 11 women had graduated from the Faculty of Forestry, but now the number of women graduating with forestry degrees has increased substantially. 
Figure 7: Number of forestry students at the University of Agriculture (1985-2005)

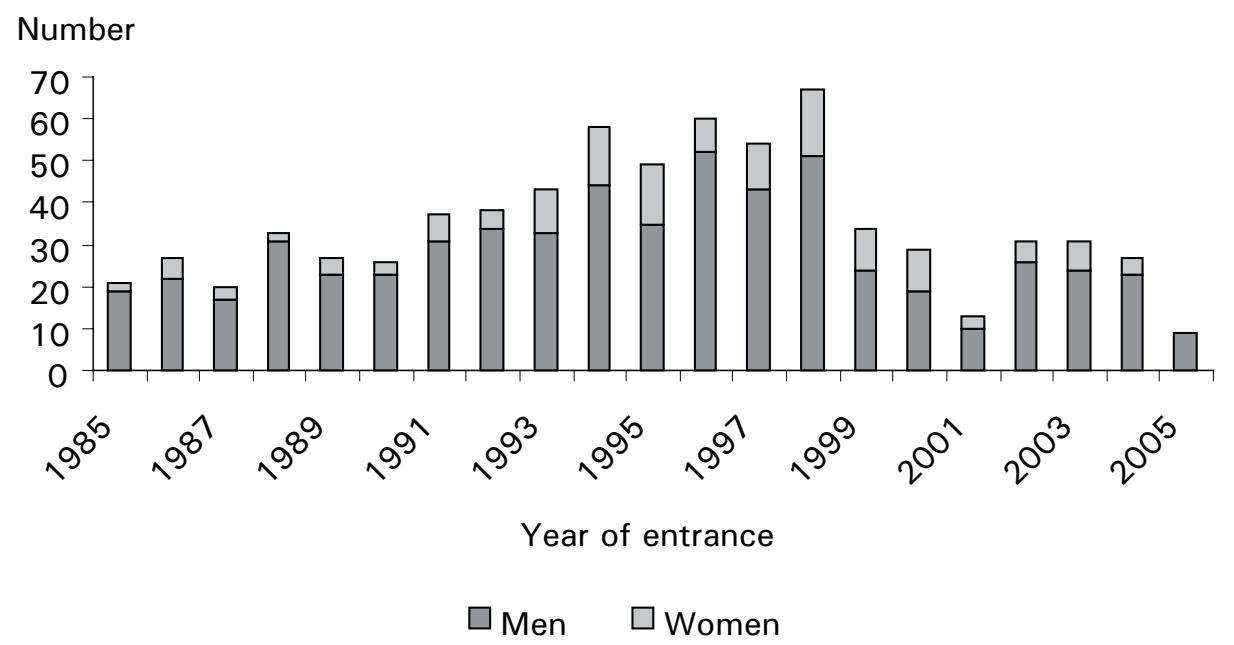

Source: Heggertveit, 2006.

Between 1985 and 2005, the total number of new forestry students at the university was 735 and the average share of women was almost 20 percent, a total of 141 female forestry students, see Figure 7 . However, in autumn 2005 no women students enrolled in the university's forestry programme (Heggertveit, 2006).

\section{University colleges}

Until recently, three university colleges offered forestry education in Norway (up to 1983, only 12 women had graduated as foresters from these schools). Gjøvik University College closed its forestry study in 2002 due to a decision made by Parliament, mostly because too many students were enrolled in forestry programmes. In 1996, the share of women graduating as foresters from this university college was 20 percent. Finally, between 1986 and 2005, 38 women graduated as foresters at the Nord-Trøndelag University College, representing a share of 13 percent on average (Kveli, 2006). Between 1992 and 2005, 14 women graduated as foresters at the Hedmark University College, representing a share of 16 percent (Hagen, 2006).

\section{Forestry schools}

In 1985, about 90 women had graduated from Norwegian forestry schools. From 1986 to 1989, the percentage of new female students at these schools (14 to 19 years old) increased from 6 percent to 14 percent. However, in 1995 the share of women was only 7 percent. The current figures are not available.

\section{Summary and conclusions}

In Norway, the share of female forestry graduates increased during the 1990s. However, the general 
reduced need for forestry graduates within the sector has reduced the total number of forestry graduates from the university and university colleges by one-third compared with the 1990s. While at present very few women study forestry in Norway, in the 1990s the share was between 15 and 20 percent. Altogether, 150 women have graduated from the Forestry Faculty of the Norwegian University of Agriculture; however, only a few of them are visible in the industry.

\subsubsection{Gender representation in Norway}

Although the means and the actions to increase the number of women within the Norwegian forestry sector have been on the agenda for 20 years, the share of women within the sector is still low. Recently, however, significant improvements have been reached in the private sector, mainly because of successful political actions.

\section{Stage 1: The pioneer period (1986-1996)}

In the pioneer stage, the minister as well as the executives - particularly within the Ministry of Agriculture and the Norwegian Forest Owners' Federation - supported actions regarding gender issues. Women in Forestry played a key role in women's entrance into the forestry sector. The means and actions during this period were a result of the conditions of the forestry sector at the time.

Both men as well as other women had to change their views and accept women's new positions within the sector. In particular, there was a need to achieve acceptance of women as resources within the forest owners' organizations. Role models were needed. The pioneers were visible and their actions were observed and judged by the forestry sector. They also provided women in forestry with information and support. In addition, several obstacles had to be overcome so that women could enter the forestry sector easily. A few local forest owners' organizations changed by-laws to stimulate women's participation.

The forestry sector economy was relatively sound in this period, and in theory many positions were available for female applicants in the private as well as the public sector. From 1986 to 1991, the number of employees within the forest owners' organizations increased by 25 percent and remained stable until 1996.

\section{Stage 2: The silent period (1996-2003)}

During the second stage, one would have expected that gender balance had made major progress. Clearly, this was not the case - neither in the public nor the private sector - as the gender issue was taken off the agenda. Even Women in Forestry focused on internal affairs. To be fair, this organization was not meant to replace the responsibility that established organizations had for making gender improvements and therefore cannot be blamed for the modest progress that was made during this period. 
The forestry sector's failure to achieve gender balance may have been caused by a combination of factors, including both hidden resistance as well as willingness but lack of successful actions. It may also have been women's own choice to avoid the forestry sector. The economic conditions within the forestry sector led to less employees and restructuring within the private sector and limited the opportunities to improve gender balance among employees to some extent. Within the Forestry Service, however, a number of positions were available during this stage.

\section{Stage 3: The requirement period (2003)}

The requirement period produced a new set of means and actions in Norway, mainly because of the government's decision to introduce a new law forcing gender balance (see Chapter 4). Several forest owners' district associations started actions to meet the 40 percent requirement of electing women members onto the board of directors by 2009. The district associations are the owners of these processes, based on board decisions, a precondition in order to be successful. Today, by-laws are in place giving two votes per forest holding and requirements concerning gender balance have been implemented. Therefore, gender balance has substantially improved, exept among the employees.

Lately, Women in Forestry has taken a more innovative role, focusing on women as key consumers and thereby demonstrating new business reasons for improved gender balance.

\subsubsection{What are the key drivers for changing the gender "agenda" forward in Norway?}

\section{A question of leadership and business}

Achieving gender balance is the responsibility of the board of directors and executives of companies as they are the persons responsible for approving objectives and gender actions, and this has to be recognized in all forestry organizations.

There is still a need to increase the understanding of the business reasons for improved gender balance among key people on different levels within the Norwegian forestry sector. Men as chairpersons of gender processes have proven to be successful and should be the preferable communicators of the reasons for gender balance.

\section{Making female forest owners motivated and recognized}

To get more women active as forest owners as well as willing to become board members, competence building should be offered with a special attention to women's needs. Ongoing revisions will likely meet this request. An introduction to forestry language should continue to be offered to groups of female forest owners 
as the first step into the forestry world, and forest owners' associations need to organize network events.

In Norway, the election committee plays a key role, for example, when board members among forest owners are recruited. These committees should be given more attention. In the past, all board members were expected to have (practical) forestry competence, but today a number of challenges have to be met by organizations and they now require a mixture of competence among the board members.

\section{Introduce market requirements}

Gender balance within the board of directors is already moving ahead in Norway. However, the government alone cannot improve balance among employees, even if laws against discrimination have been in place for years. Therefore, market tools are needed.

In Norway, the easiest way to ensure improved gender balance, for example among employees in the forest owners' organizations, is to make gender balance a part of the forest certification requirements (ref. social criteria and indicators concerning SFM). Certification is already well implemented, because for several years now all timber that is traded by the Norwegian forest owners' organizations come from certified forests meeting the Living Forests Standards (agreed by stakeholder consensus in 1998), with a system approved by the Pan European Forest Certification (PEFC). Implementation of the requirements for gender balance in the global forest certification system will most likely have an impact on Norway's forestry sector. The requirements for achieving gender balance on the board of directors and among employees must be further developed.

\section{New tools needed}

New tools and actions have to be elaborated. Thus far, 150 women have graduated as foresters from the University of Agriculture. But what are their careers like compared with men's? Why since the early 1990s have there been only 40 women forest officers out of the 300 positions available within the municipality level Forestry Service? And why is the share of women as forestry graduates within the forest owners' organizations only 4 percent? Gro Follo's doctoral study is expected to be completed in 2007 and is sure to provide valuable knowledge about the reasons behind the gender balance within the Norwegian forestry sector, particularly among forest owners. Still, further studies are needed.

\subsubsection{What are the positive benefits Norway can gain?}

In order to obtain significant improvements in gender balance within the forestry sector, board members and executives must understand the business reasons for initiating change. All means and actions within the forestry organizations have to be approved by the board of directors. 
Positive actions such as disseminating information and providing motivation and support will be needed in the first stage. A women's network can also be a helpful tool as it is a way to exchange experience and strengthen motivation among women, and is also a resource of role models and competence building. However, to achieve substantial changes in gender balance, e.g. within the organizations of forest owners, organizations must be fully committed to the gender process, a commitment that must be demonstrated in the management and practices of the organization. This will limit the need, over time, for separate organizations such as Women in Forestry.

When the Norwegian government recently introduced quota standards, immediate actions were taken and substantial improvements achieved within the forest owners' district associations. Two specific actions need to be highlighted:

- Changing by-laws - this would allow couples who together own a forest holding to have one vote each; therefore, increasing the likelihood that both become involved within the forestry sector.

- Quota requirements are needed for achieving gender balance on the board of directors, thereby forcing election committees to be more open-minded when selecting new members of the board and to recognize women's competencies.

\subsection{POLAND}

\section{By Wiestawa L. Nowacka and Bożena Kornatowska}

\section{Introduction}

The aim of this paper is to provide key information regarding the status of women in Poland, especially within the forestry sector. Historical background and the development of women's participation in the sector will be discussed, taking into account employment changes that have occurred in recent years.

The data used in this study were collected from a wide range of sources. The information is based mainly on Nowacka's research results (manuscript, 2005) on employment in the forestry sector (regional directorates of state forests, state forest districts, national parks, universities, etc.) as well as on information on the uses of forest resources by rural women who live near forests. In addition, various data were obtained from relevant literature sources and from credible Internet sites. Trends in employment will also be presented by using statistical data from the Central Statistical Office (GUS).

Reliable data proved to be difficult to find in many cases. Statistical information was therefore supplemented by the results of an enquiry on the forestry labour force, which is also included in Nowacka's 
habilitation thesis (in progress). In order to study gender distribution in the labour force, a questionnaire requesting data on employment and other aspects of work was distributed to the State Forest Districts. Almost 150 of them (more than one third of all that exist in Poland) responded; however, some of the replies were incomplete.

The political and economic transformations that took place in Poland after 1989 contributed to developing forestry services in the private sector, but at the same time there were reductions in the workforce, especially with regard to women. These changes caused difficulties in comparing and interpreting data from periods before and after this critical year. In some cases, the data were incomplete or inaccurate, even in spite of the considerable effort invested in collecting the information. Thus, the estimates are not always as robust as one might wish. Although the results are not always fully certain, they still provide significant information on current and future trends.

\subsubsection{Background}

Women have always played an important role in Poland's history. The history of Poland is complicated and difficult: while men fought for independence, women ran the family businesses and raised their children with the spirit of patriotism. The so-called "mother Pole" became a symbol of strength and sacrifice and she was expected to abandon her ambitions and goals in the name of family and nation. Women in contemporary Poland are still expected to give up their ambitions for the careers of their husbands and for the needs of their children.

In Poland, women's salaries are generally lower than men's. Research results from a study conducted in 2002 on employment and wages show that men's income was 8.8 percent higher than the average salary, while women's income posted 16.9 percent lower than the average.

From the above, it is clear that women earn less pay than men even though they may hold the same job position and even though they present themselves in the same professional manner (Kostarczyk, 2005). Women also face great difficulties when looking for new job opportunities, and when they are in their profession they often experience other aspects of inequality at the workplace.

The 1990s in Poland were characterized, on the one hand, by intensive restructuring of the economic system (the transformation from a centralized economy to a market-based one) and, on the other hand, by maintaining and keeping in place the consolidated structure of state forests. It is expected that in this decade, the forestry sector will further cut back on its employment needs, and women will be at the core of these reductions (Kwiatkowski et al., 2001). 
In countries that have experienced significant political, social and economical transformation, unemployment has been severe. Poland's so-called structural unemployment has become of special significance, affecting regions previously encompassed within a planned economy model for agriculture, in which villagers had been assured of full-time employment in the national agricultural collectives. Following their privatization, local communities were not offered alternative means of employment. For many tens of thousands of families living in small settlements, villages and small towns, the forest became a real source of income. Advantages that come from being in the proximity of the forest are improving the social and living conditions of these families.

Similar with other countries, forests in Poland no longer play their former role of just providing timber. Now special importance has become attached to their ecological functions - the conservation of biodiversity and the protection of soil, water and air - and to their social dimensions - possibilities of forestry employment, recreational uses. On the other hand, substantial differences between women's and men's earnings, difficulties women face when pursuing a professional career, the employment rate not matching the gender ratio of graduates of the different levels of education are just a few examples of the other issues within Poland's forestry sector.

The status of women in Polish families has transformed over the centuries and has created conditions where women equally participate in providing for their families' welfare, food and stability. This equality, however, differs in urban and rural families. Opportunities for remunerated work are scarce in small communities, especially for women. Consequently, their activities toward the welfare of the family are more often tied to domestic work and to extracting benefits from the forests. Women and children living in small villages are primary users of forests. Gathering mushrooms, wild fruit and herbs have become incomegenerating activities and are often the only source of financial support for the family. Moreover, following local traditions and values, rural women continue to preserve fruit and mushrooms, which provides a substantive supplement to the family's diet all year long (Nowacka, 2004), not to mention additional income for the household.

\subsubsection{General characteristics of Poland's forests and forestry}

The forest area in Poland is 8918000 hectares (GUS, 2002), which accounts for 28.5 percent of the country's area. State-owned forests predominate in Poland and amount to 82.6 percent of its total land area (7.2 million hectares). Within this figure, 78.4 percent is under the management of the National Forest Holding "State Forests". The remaining state-owned forests are components of national parks and local councils. Meanwhile, privately owned forests account for 1.5 million hectares and are managed by about 1.5 million small-scale private owners (Forests in Poland, 2000). 
Timber resources from state forests continue to increase. In 2003, they reached 1.6 billion $\mathrm{m}^{3}$ of merchantable timber over bark. Including the resources in private or local authority hands, the overall standing volume in Poland's forests is estimated to be 1.9 billion $\mathrm{m}^{3}$. The amount of timber harvested in relation to the increase in volume in forests is still very low and attains the level of about 50 percent of the annual volume increment of standing timber resources.

\subsubsection{Gender in forest ownership}

The structure of forest ownership in Poland clearly shows that state ownership and management dominate. Since private ownership of forests is limited, knowledge on private forest owners is unavailable. According to further research by Nowacka (publication in progress, 2006), based on the information gathered from foresters, women constitute no more than several percent of the total number of forest owners, the majority being women who had acquired forests by inheritance. For the most part, forest owners' associations do not exist in Poland, except for some small regional cooperatives (Małopolska Region, southern Poland), and as a consequence data concerning women forest owners are difficult to obtain.

\section{Women in forestry - old problems, new approaches}

Similar to other countries, Polish women and men have equal prospects in terms of education, employment, professional careers and salaries. This is the law and theoretically this is how it should work; however, the truth might be different. In examining one of the aspects in the forestry sector of the 1960s - women forestry students - the number of women studying forestry was low, though records show that even before the Second World War women had been registered in forestry faculties. This situation has changed radically in the last three decades. Table 25 below presents the percentage of women students and the graduates from forestry faculties.

Table 25: Women students and graduates from the Faculties of Forestry at Agricultural Universities in Krakow, Poznan and Warsaw, 1985-1999

\begin{tabular}{lcc}
\hline Year & Students (\%) & Graduates (\%) \\
\hline $1985 / 86$ & 19.4 & 24.2 \\
$1990 / 91$ & 13.9 & 15.9 \\
$1995 / 96$ & 14.3 & 17.7 \\
$1996 / 97$ & 15.2 & 12.9 \\
$1997 / 98$ & 16.1 & 15.7 \\
$1998 / 99$ & 17.0 & 18.3 \\
\hline
\end{tabular}

Some issues to ponder are whether the number of women students and graduates reflect their further employment, their professional careers and the positions achieved in the forest sector. Unfortunately, it does 
not appear that way. Taking into account the present labour conditions in Poland, men are more able to find employment in the forest sector than women. One must wonder if it arises from men being more competent in school (and marketability at graduation), but when analyzing the data the differences between the graduates in the forestry faculty are insignificant, even this being so, women seem to be better performers in their school studies.

Figure 8 presents the participation rate of women who are in management positions in State Forests. The number of women studying forestry as well as their achievements during their university studies do not correlate directly with the number of managerial positions they later hold in the forestry sector. The first woman manager - a supervisor - of the Forest District was employed in the 1990s (Zubkowicz, 2005).

Figure 8: Women in management positions at State Forests: Directorate General of the State Forest

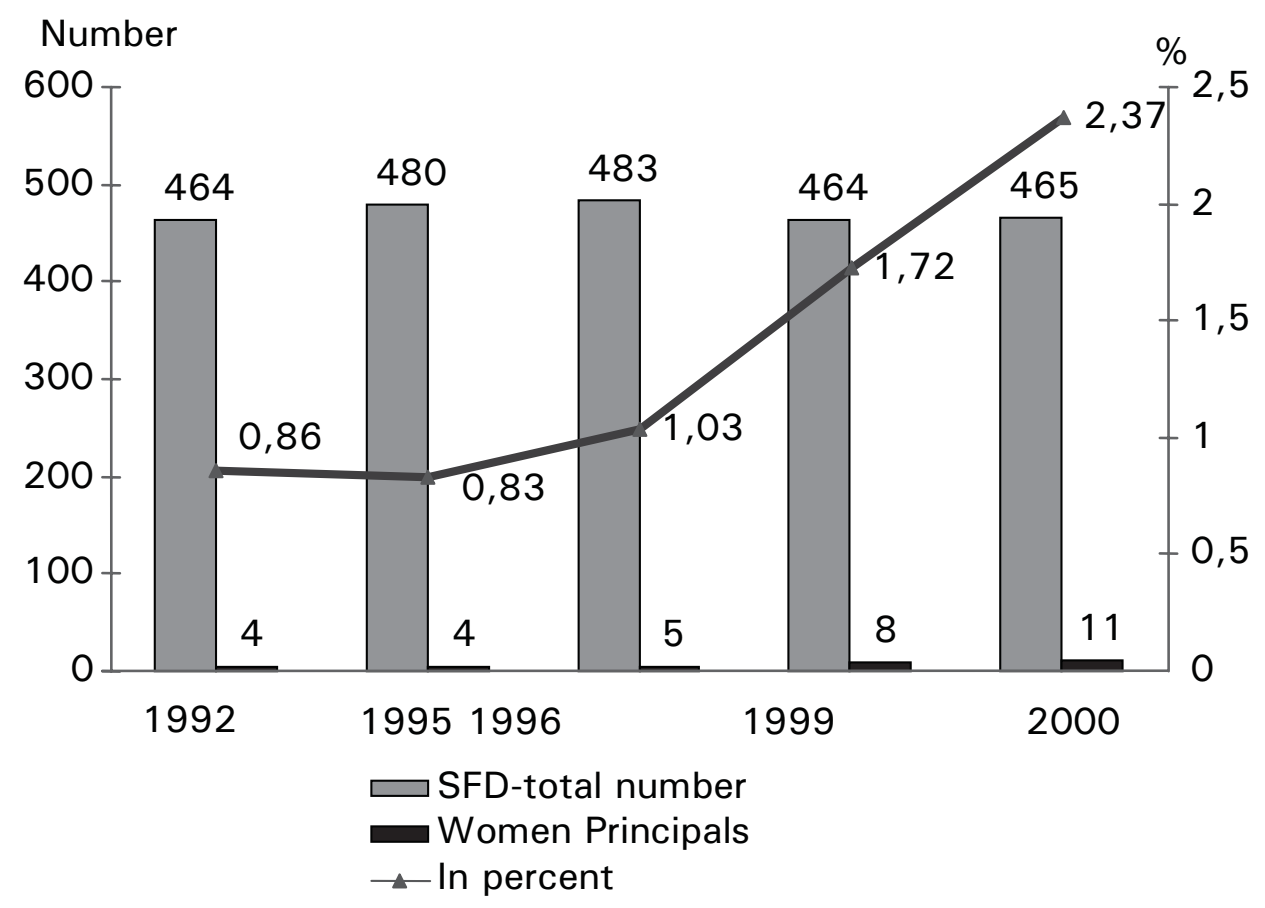

Since 2001, the number of women employed as managers in the Forest Districts (438) has not changed: currently, eight women are supervisors in charge of State Forest Districts (Nowacka, 2001). Although there has been much shifting around in the higher level job positions of the State Forests, not one woman has lost her job. With regard to the country's 23 national parks, however, men hold all higher managerial positions, and there has never been a woman director of the national park.

Nevertheless, a positive tendency regarding women employment can be observed in the forestry sector: in all regional directorates (17), at least one woman is employed as a section supervisor or above. Yet, in general, women usually work as principal accountants or in various jobs in administration units or in the departments of planning and data processing. 


\section{Uses of forests by women of neighbouring villages and country towns}

The research carried out in 2004-2005 resulted in the collection of more than 1000 completed questionnaires; the results from 500 of these (Nowacka, 2004a) are presented here. The study found that more than 55 percent of the respondents live in small villages (approximately 1000 inhabitants); that most were women (67 percent) between 16 to 48 years of age; and that the monthly income of a representative family was under 600 PLN (around 150 euros) per capita, with almost one-third of the families living below the minimum average income. Most of the families treated the selling of different forest products as a source for additional income, and children also helped out and collected mushrooms or forest fruit. The results are presented in Table 26 below and provide data on forest uses that benefit rural families and local communities.

Table 26: Means of typical forest uses by women in local communities

\begin{tabular}{lc}
\hline \multicolumn{1}{c}{ Means of use } & \% of users \\
\hline Mushroom collecting for family use & 35 \\
\hline Mushroom collecting for selling & 25 \\
\hline Forest fruit collecting for family use & 32 \\
\hline Forest fruit collecting for selling & 28 \\
\hline Fuelwood (bought economically when families lived closer to forest) & 16 \\
\hline Forest herb and flower collecting & 6 \\
\hline Other activities & 5 \\
\hline Brushwood (available without spending money) & 3 \\
\hline Pasturage, beekeeping, snail gathering, tourism: each one & 1 \\
\hline
\end{tabular}

\subsubsection{Employment in Poland and the forestry sector}

The changeover to a free-market economy had a dramatic effect on the employees of the State Forests who had previously enjoyed stable employment. At the beginning of the 1990s, large numbers of workers were laid off and reemployed as contractors. Between 1989 and 1996, the reduced workforce amounted to 45834 , which was 6 percent of the total number of employees.

The overall employment in Poland's forestry decreased from 158900 in 1985 to 64400 in 1994 (www. lasypanstwowe.gov.pl); by 2003 the State Forests employed only 27500 people. The decline in employment in the forestry sector affected women especially: women's employment rate was estimated to be about 20 percent. Newly established forest enterprises have been mainly established by men and have offered employment only to men. In practice, only nurseries or silviculture companies have employed women (Nowacka 2004b; Nowacka, 2005).

In Poland, unemployment "officially" had not existed before the transformation of the political system in 1989. However, statistics revealed that at the end of the 1980s more than one million people were unemployed 
in the country. When unemployment emerged in 1990, it grew rapidly and by 2002 it was at its highest level - about 3.2 million unemployed persons (Nowacka et al., 2006).

Table 27: Employment indicator by gender (\%), in 1994-2003

\begin{tabular}{lllllllllll}
\hline Gender & $\mathbf{1 9 9 4}$ & $\mathbf{1 9 9 5}$ & $\mathbf{1 9 9 6}$ & $\mathbf{1 9 9 7}$ & $\mathbf{1 9 9 8}$ & $\mathbf{1 9 9 9}$ & $\mathbf{2 0 0 0}$ & $\mathbf{2 0 0 1}$ & $\mathbf{2 0 0 2}$ & $\mathbf{2 0 0 3}$ \\
\hline Men & 58.8 & 58.5 & 59.4 & 59.8 & 58.9 & 55.9 & 55.2 & 52.5 & 50.7 & 50.9 \\
\hline Women & 44.0 & 43.7 & 43.8 & 44.0 & 43.9 & 40.7 & 40.3 & 39.0 & 38.1 & 38.2 \\
\hline
\end{tabular}

At the beginning of the 1990s, Poland's State Forests employed about 134000 people. At the same time, privatization of forest operations had just started to take off. The realization of forest services was taken over by private companies, which came into being by hiring unemployed workers from the forest districts. As a result of restructuring, the number of people working for the State Forests began to decrease every year, and by 2002 only 55400 people remained employed at the State Forests. With about 16000 employees, private forest enterprises are continuously in the restructuring process.

Until the end of 1980s, various forest operations in the State Forests were carried out mainly by workers employed directly by the enterprise. Big changes occurred in 1995 when more than 20000 workers shifted to the private sector. Currently, the State Forests employ about 27000 people (15 000 in forest service, 6000 in administration, and about 6000 general workers).

Figure 9 presents women's employment in the forestry sector compared with employment in the country. The data were obtained from 150 Forest Districts, which means that more than one-third of forest units of this kind were taken into account. Therefore, the results presented can be regarded as representative of Poland's situation.

Figure 9: Employment in State Forest Districts in 1990-2003

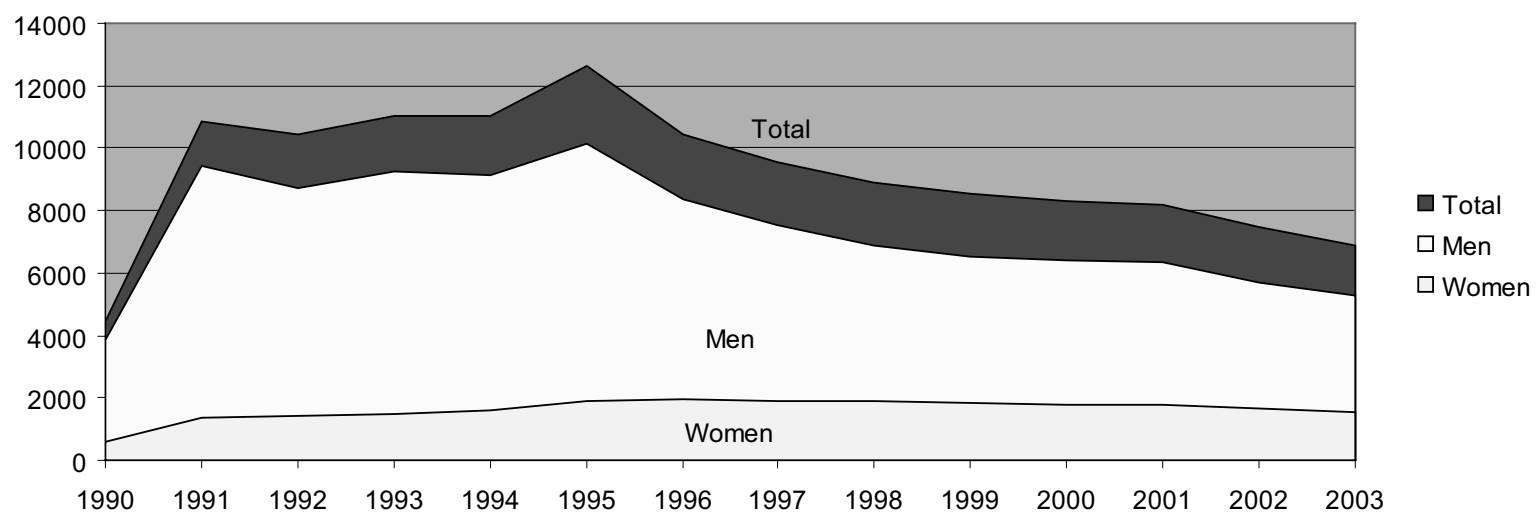

The data presented in Figure 10 demonstrate a slightly increasing participation of women in working in the Forest Districts. 
Figure 10: Women employed in the State Forest Districts in 1990-2003

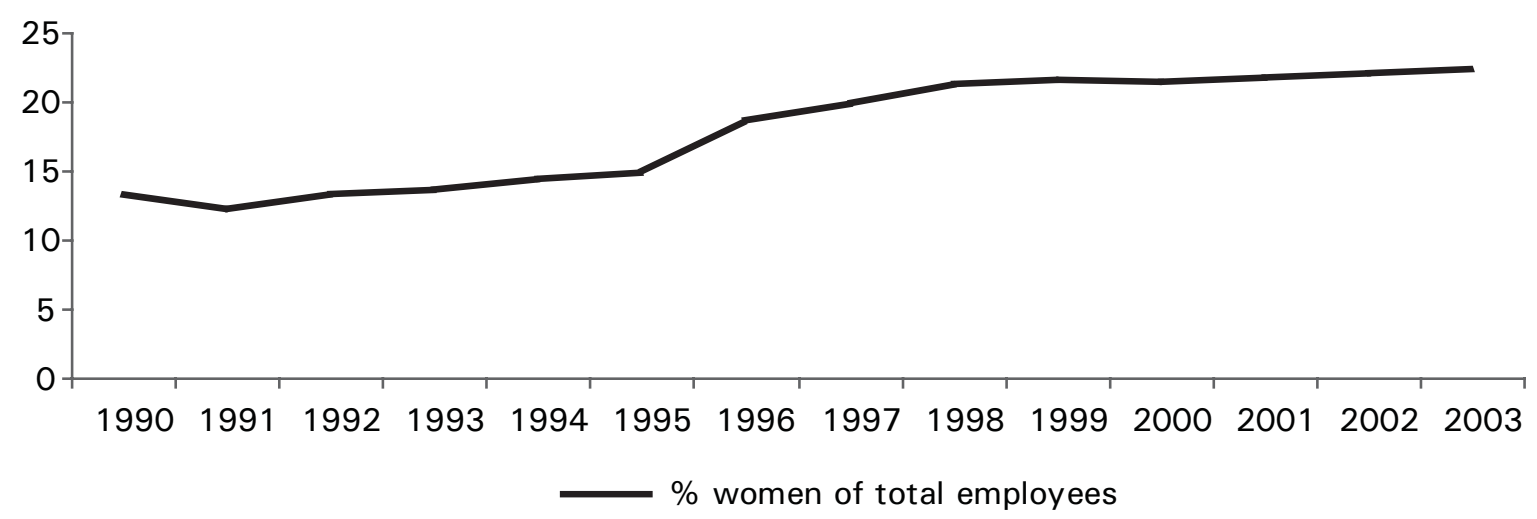

\subsubsection{Women in science}

In 2004, the report "Wasted Talents: Women in Science in the Countries of East Central Europe" was elaborated by a team of specialists created by female representatives of the countries of East Central Europe and the Baltic States. Professor Ene Ergma, the Chair of the Parliament of Estonia and the Deputy Director of the Estonian Academy of Sciences led the team. The report was prepared for the European Commission and presented at the East Central Europe Conference held in Warsaw, Poland (2004) (http://dziennik.pap.com. $\mathrm{pl} /$ index.html). Among other things, the report concluded that many women scientists in the countries of East Central Europe and the Baltic States were involved in insufficiently funded research and that women who were employed at universities were mainly occupied with teaching.

The official statement presented at the East Central Europe Conference does not fully reflect the situation in Poland's education and science system. For example, the Ministry of Education and Science does not have any women in top positions, and the positions of minister, state secretary and undersecretaries of state (five altogether) are held only by men. Furthermore, only two women are on Poland's Board of Science (70 members), and only five women among the 33 members of the Polish Board of Higher Education for IX cadency in 2006-2009. These figures show that in the currently acting decision bodies of Poland's science and education sector, women constitute only a 5.52 percent participation rate.

\subsubsection{Conclusion}

The political, social and economic transformation that Poland experienced after 1989 contributed to the development of private services in forestry, but at the same time reduced employment, especially regarding women's employment. 
The switch to a free-market economy had a dramatic effect on the employees of the State Forests. At the beginning of the 1990s, large numbers of workers were laid off and reemployed as contractors. Between 1985 and 1994, overall employment in the forestry sector decreased from 158900 to 64 400. By 2003, the State Forests employed 27500 people.

Employment status in the forestry sector is characterized by the employment rate not matching a gender ratio of graduates from different levels of forestry education and by the substantial differences between women's and men's earnings.

In general, women in the State Forests are usually employed as principal accountants or they occupy various positions in administration units or the departments of planning and data processing. Opportunities for remunerated work are scarce in small communities, especially for women. Consequently, their activities toward the welfare of their family are more often tied to domestic work and to extracting benefits from forests.

Polish women constitute less than five percent of the total number of private forest owners and currently constitute about the same percentage - 5.52 percent - in acting decision bodies in the country's science and education sector.

\subsection{SLOVAKIA}

\section{The role of women and female foresters in the Slovak Republic}

By Viera Petrasova and Zusana Sarvasova - Forest Research Institute, Zvolen

\subsubsection{Introduction}

Slovakia has a forest cover of almost 2 million hectares, or 41 percent of the country's surface; about 60 percent of the territory is declared rural. The state and municipalities own more than 50 percent of forests. Between 1990 and 2004, employment in the forestry sector declined dramatically: in 1990 the sector employed more than 40000 people, while in 2004 there were only 15000 workers. From this figure, the state forest sector employs 8300 people, of which 82 percent are men and 18 percent women.

\subsubsection{Women's situation in Slovakia}

Women comprise 51.6 percent of the population in Slovakia. At the same time, 45 percent of the total amount of the unemployed are women, despite the fact that women are generally believed to be as well educated as men. After having accepted the commitments of the Platform for Action at the Fourth World Conference on Women in Beijing, Slovakia drew up a National Action Plan for Slovakian women in 1997. The 
plan declares equal rights and equal positions for women. One of its goals is to improve the labour market for rural women. However, gender policies, even despite this action plan and commitment by the government, are theoretical.

Differences in income of up to 30 percent were found when comparing wages of men and women of the same age and education level. This can be explained by the way men and women are classified in job positions, as well as by the smaller scale of women in top positions, lower proportion of women in shift work as well as the continuing practice in higher financial valuation of men as the main family providers. Slovakian women carry out most household activities, which are listed as unpaid work: the estimates of specialists on average daily values form almost 40 percent proportion of the work done in the employing process.

\subsubsection{Educational level of female foresters}

Forestry study at the university level in Slovakia dates to 1947; however, with restrictions for women until 1962. Because forestry was traditionally seen as a male occupation and because of the lower qualification level for women of that period, women had little interest in the forestry professions. The interest, however, increased in the 1960s and lasted through the 1980s.

Table 28: Number of women graduates at the Forestry Faculty, 1947-2000

\begin{tabular}{|c|c|c|c|}
\hline \multirow[t]{2}{*}{ Year } & \multirow[t]{2}{*}{ Total number of graduates } & \multicolumn{2}{|c|}{$\%$ women } \\
\hline & & Number & $\%$ \\
\hline $1947-1952$ & 334 & 4 & 1.2 \\
\hline 1953-1962 & 529 & 37 & 7.1 \\
\hline 1963-1972 & 775 & 73 & 9.4 \\
\hline 1973-1982 & 960 & 113 & 11.7 \\
\hline 1983-1992 & 1404 & 223 & 15.9 \\
\hline $1993-2000$ & 874 & 189 & 21.6 \\
\hline Total & 4876 & 639 & 13.1 \\
\hline
\end{tabular}

After 1980, there were no restrictions for admitting women into the forestry programme, and the number of women increased by 10 percent. In 1990, because of economic and political changes in Slovakia all students were able to attend universities. At present, the number of women graduating from forestry programmes has increased again, reaching almost 30 percent of the total number of graduates.

Before 1996, adolescent girls were only able to study forestry at university level, but the financing of secondary schools was amended in 1996 (depending on the number of students) and gave adolescent girls opportunities to pursue forestry education at secondary schools. At present, young women are accepted in all fields of forestry at secondary schools:

- Forestry - forestry operations in practice

- Forestry - landscape ecology 
- Forestry - forestry services

Despite the increasing proportion of women graduates in the Forestry Faculty since the beginning of the 1980s, their number in forestry practice grew only until 1990. After 1990, a reprivatization process started, which abolished the monopoly of the state forest enterprise.

Table 29 presents an analysis of the country's gender representation in forest organizations in 2004 while Table 30 presents the positions that women hold in state forest enterprises.

Table 29: Gender representation

\begin{tabular}{lccc}
\hline Organization & Total number & Men (\%) & Women (\%) \\
\hline Forest state enterprise (technical/managerial staff only) & 3045 & 86 & 14 \\
\hline Forestry Faculty of Technical University, Zvolen & 153 & 64 & 36 \\
\hline Forest Research Institute, Zvolen & 130 & 56 & 44 \\
\hline
\end{tabular}

Table 30: Women by positions within the state forest enterprise - Lesy SR, district of Banská Bystrica - 2006* Headquarters:

\begin{tabular}{lcc}
\hline & & 2006 \\
\cline { 2 - 3 } Position & Number & \% \\
\hline General director & - & - \\
\hline Division director & - & - \\
\hline Section director & - & 10 \\
\hline Department chief & 2 & 36 \\
\hline Other positions - Engineer employees & 23 & 53 \\
\hline Other positions - Other employees & 17 & - \\
\hline
\end{tabular}

Affiliated forest enterprises (AFE)

\begin{tabular}{lcc}
\hline & & $\mathbf{2 0 0 6}$ \\
\cline { 2 - 3 } Position & Number & $\mathbf{\%}$ \\
\hline Director & 2 & 7 \\
\hline Department chief & 10 & 12 \\
\hline Other positions - Engineer employees & 70 & 21 \\
\hline Other positions - Other employees & 177 & 48 \\
\hline
\end{tabular}

*Data are available only for the state sector. There are no data available for the non-state sector. Women in other positions are, in general, employees at the same decision level and mostly represent administrative positions in different departments.

\subsubsection{Conclusion}

Slovakia is largely rural. The transformation of the national economy, which included the forestry sector, has led to high unemployment rates. The restrictions for women entering the professional forestry workforce after studying have dropped after 1980. Although the number of women graduates grew, their career chances did not grow adequately. Research must be carried out to understand the reasons and develop national action plans for gender in forestry. 


\subsection{Sweden}

By Gun Lidestav

\subsubsection{Swedish Forestry in general}

Two-thirds of Sweden's land area is covered with forests, and of the 27.1 million hectares of forestland, 785 hectares are in economic use. During the last decade, the average annual fellings have been some $60 \mathrm{million}^{3}(75$ percent of the increment); however, in the past two years, harvesting volumes have reached 80 million $\mathrm{m}^{3}$ or more. In terms of forest industry production, forestry products made up 12 percent of the total Swedish export value in 2004 (National Board of Forestry, 2005). The forestry sector employed 16500 people and the wood-processing industries 71 650, of which 14 percent were women, a significant reduction compared with 1990 (23 percent).

\subsubsection{The current status quo of gender representations across organizations in Sweden}

Forest companies, including publicly owned forestry companies and forest owners associations

In forestry, only 7 percent (or about 1400 ) of the total number of employed persons in forestry were women. The number and proportion of women have decreased significantly since 1990, when 13 percent of all people employed were women (National Board of Forestry, 2005). In large-scale forestry (companies with more than 10 employees or more than 5000 hectares forestland), harvesting operations, silviculture and roundwood measurement there are 15 percent women, which is just slightly higher than a decade ago. Yet, only 8 percent of all women have a permanent job while 33 percent of men are permanently employed. For both women and men, permanent employment has become less common since 1995. In addition, about 360 women (6 percent of the workforce) work in contractor firms as partner owners or employees. Most of these women have administrative positions, but a small number of them work as machine operators (National Board of Forestry, 2005).

In Sweden, among the employees who have higher education (postsecondary school) there are 5 percent women, and those with a master's degree or higher, 12 percent. The women who had master's degrees in 2003 had an average salary of 73 percent of their male colleagues (Ds 2004:39). Female workers in forestry (and agriculture) had an average hourly wage of 90 percent of a male worker (National Board of Forestry, 2005).

\section{National, regional and county boards of forestry (since January 2006, Swedish Forest Agency)}

In 2003, 1091 employees were employed at 1091 employees, with 115 working at the National Board of Forestry, of whom 35 percent were women. At the regional and district level region offices there were 
976 employees, with 24 percent women. The gender balance among the regions differs substantially, from 15 percent to 30 percent, and there are considerable differences concerning the gender balance within the various positions. The percentage of women holding the following positions are: top-level positions 11 percent; district leaders 8 percent; forest rangers 11 percent; specialists 28 percent; administration 87 percent; and foremen 9 percent. In addition, it should be mentioned that among employees with a university degree in forestry (bachelor's or master's) from 1984-1993, the average salary for women was about 15 percent less. (Ds 2004:39).

\section{Universities and research institutions}

About 400 young people, less than 5 percent young women, study forestry each year at the high school level (or vocational training). After graduation, some find jobs in practical forestry work as machine operators, for example, and others continue their education in forestry (or other subjects). For higher forestry education, the Faculty of Forestry at the Swedish University of Agricultural Science in forest science offers a 3-year programme for forest engineers and a 4- to 5-year programme for a master's in forestry. Because there is a prerequisite of having work experience in forestry for acceptance into the forest engineering programme, the number of female students has generally been about 5 percent or less. The proportion of women teachers in the forestry schools is even lower.

During the last two decades, the proportion of female students graduating with master's degrees has fluctuated between 20 to 30 percent. While the female students usually enrol in ecology and biology courses, male students usually take management, technology, and economics for specialization (Jämställdhetsplan för Skogsfakulteten, 2004).

With regard to the staff at the Faculty of Forestry, of 548 employees 170 are women (or 31 percent); among technical and administrative staff, 41 percent are women. The proportion of female researchers and lecturers at the faculty is low, at 14 percent; however, there has been an increase in the number of women Ph.D. students (45 percent) (Jämställdhetsplan för Skogsfakulteten, 2004).

Furthermore, in research institutes such as SkogForsk, 25 percent of all employees are women (28 out of 110): those who hold research positions amount to 20 percent and those in administration positions 60 percent.

\section{Wood processing industries}

Of the 71000 employees in wood processing industries, 14 percent are women. Here too the number as well as the proportion of women has decreased -23 percent in 1990 .

To sum up, female forestry professionals are in the minority, especially in practical work and in top-level 
positions. Women mainly work in administrative and assistant positions, and more often with forest authorities than with forest companies.

\subsubsection{Why is gender representation the way it is?}

Female foresters working in the forestry sector find themselves in an organization and structure dominated by men, in terms both of number as well as positions, although the number of women with forestry degrees has increased substantially. Previous studies (Lidestav and Wästerlund, 1998; Ringsell, 2000) have suggested that female foresters are less satisfied with their jobs than their male colleagues are. Within most forestry spheres, gender marking is still so obvious that women stand out as deviant and they constantly have to justify their presence (Brandth and Haugen, 1998; Brandth et al., 2004; Reed, 2003). The best chances to become accepted and esteemed seem to be as experts in a more and more specialized field or when working with education and dissemination of knowledge (Brandth and Haugen, 1998; Brandth et al., 2004). A gendered division of areas and functions at both a horizontal and a hierarchal level appears when comparing contemporary occupations in Sweden between men and women with a degree in forestry (Lidestav and Wästerlund, 1998). In education, information and supervision of law, as well as in subordinated positions, the proportion of women corresponds fairly well to the proportion of female graduates. However, if we look at the proportion of women in higher positions, within management, harvesting operations, silviculture or working as experts, the amount is lower than the proportion of graduates.

As long as there are few women who study forestry, there will also be few women in the workforce - and as long as young women do not find forestry as an attractive field, one that offers them good possibilities to acquiring interesting jobs and having careers (receiving an equal salary), there will be a minority of women in the forestry sector. Further, within organizations (business and authorities) a gendered organizational logic is at work, which not only reproduces a structure of gender division but also, paradoxically, makes gender invisible (Wahl et al., 2001; Wahl, 2003). Different professional positions in organizations have a more or less determined gender character, and women in male-dominated professions or workplaces often face problems of "fitting in" (Magnusson, 1998). In all, this can be expressed by the concept of genderization. The following section presents the results from a critical discourse analysis of forest professions (Lidstav and Sjölander, 2005). Specifically, it is the discourse of forest supervisors (a person with a degree in forestry and employed by one of the county forestry boards), and forest rangers (employees with higher forestry education, employed by private or public forest enterprises). The analysis is based on written texts and images about the forestry professions published in some major national forestry magazines in 1990 and 1991 and in 2000 and 2001. 


\section{The question addressed was: How do women fit in with the forestry professional discourse?}

The study (Lidestav and Sjölander, 2005) reveals that a fifth of the magazine texts includes women, and around half of these mark gender or deal explicitly with equality issues. This percentage is significantly higher than the amount of women working in the field, but the representation question is more complex. There is a strong common feature in the material that was studied, that either the author of the text or the person interviewed emphasizes that gender has nothing to do with forestry professions. This pattern, to make gender a non-issue, seems to be a joint interest between different actors, male and female, within the discourse. There are very few exceptions and for the women in particular this appears to be a more or less conscious strategy to get access to and be accepted in the field. Brandth et al. (2004) also found similar results when studying the Norwegian forestry press. For the organizations and their male representatives, the motive to make gender invisible can be interpreted as a way to maintain the status quo (Höjer and Åse, 1996). However, only a small number of texts apply a kind of essentialistic approach, pointing out that there are profound differences between the sexes. Some of them claim that this is an advantage; others say it is a fault that needs to be mended, either through women adjusting or by making use of (more and better) technology.

Three main types of arguments, often mixed together, have been identified as being used to increase the amount of female foresters working in the field. One is a deficit argument, where women are viewed as an underused resource, which could solve the predicted lack of manpower in the years to come within the industry. Apart from the reason, we have also identified a renewal argument in which females are seen as desirable modernizers in a relatively conservative culture in need of change (cf. Brandth and Haugen, 1998). The last type of argument concerns legitimacy. The forest industry ranks very low compared to other sectors when it comes to gender equality. This creates a lack of legitimacy in relation to the surrounding society (cf. Brandth et al., 2004). A larger proportion of female rangers and supervisors, and their expected revitalizing, innovative efforts, is suggested as a way to solve the legitimacy problem that the forestry field suffers from. Another important result from the analysis concerning genderization is the notion that female foresters frequently receive their legitimacy as professionals through a man (cf. Reed, 2003). The studied narratives are full of examples where the portrayed forester refers to their own father or some other male mentor from whom they have been given access to the forestry field and its treasures. No equivalent female role model appears in these stories (Lidestav and Sjölander, 2005).

During the ten-year study period, it seems as very little has changed in terms of genderization. Rather, the discourse continues to (re)produce a manifest portrait of the ideal forester as a man, "being hard-working and able to master nature". This hegemonic masculinity is to a large extent formed around a rural masculine identity 
including, for example, a strong interest in hunting and wildlife (Connell, 1995; Brandth and Haugen, 2004). At the same time, female foresters appear to need a male mentor in order to enter the field, because it is through such a "helper" that they seem to receive legitimacy as professionals. These stereotyped gendered patterns do not make it easy for women, or men for that matter, to "fit in" within the field. Even though the forestry industry has undergone significant changes and there is a concern about future lack of manpower, etc., few signs of reform concerning the current gender structure and equality issues can be observed in the studied representations. On the contrary, there is a strong tendency in the forestry press to state that gender does not matter. Both men and women within the forestry field apply this universality strategy, which could be interpreted as a way to avoid any kind of "feminist stigma" (Brandth et al., 2004). As Reed's (2003) analysis of forestry work and gender relations in Canada reveals, it is important to keep in mind in this context that gender relations are formed by both men and women, a phenomenon that is also illustrated here (Lidstav and Sjölander, 2005).

"Breaking into the forestry discourse is hard work", conclude Brandth and Haugen (1998) in their longitudinal analysis of the Norwegian forestry discourse, having reviewed the results of women's attempts to gain influence but, as indicated by their research, with minimal success. The same can be said about the Swedish case (Lidstav and Sjölander, 2005). It appears to be hard work to break the dominant masculine forestry discourse. Overall, the discourse reproduces the traditional male-dominated culture and offers very few alternatives. This has social impact and affects the opportunities for individuals to identify with, and to choose to be, a professional forester. Even so, one should remember that, however manifest discourses appear to be, they are always changeable (Berger and Luckmann, 1966; Winther-Jörgensen and Philips, 1999).

\title{
1.14 UNITED KINGDOM
}

\author{
By Patricia Tomlin
}

\section{Gender balance in employment within the United Kingdom forestry industry}

Industry context: About 2.8 million hectares make up the woodland in the United Kingdom (as of March 2003). A total of $9.9 \mathrm{~m}^{3}$ overbark standing were sold in the country in 2002, with a total of 7.2 million tonnes felled and sold to the wood processing industry (a reduction of 3 percent from 2001).

\subsubsection{Employment of women in UK forestry industry}

There is little consistent data available on the representation of women across the industry in the United Kingdom, the sectors they are employed in or the jobs they do. There are, however, a number of sources that provide indications of the number of women and where in the industry they work. 
According to the last Forest Employment Survey, undertaken by the British Forestry Commission, 29532 people (based on a full-time equivalent calculation) were employed in the industry in 1998/1999. This revealed a reduction of 15 percent since the last survey in 1993/1994. This is the most up-to-date available information for the whole industry (sampling included Forestry Commission, private woodland owners, private forestry companies, contractors, wood processing, haulage and research, although excludes arboriculture). This major industry survey, however, has never collected data that provides a breakdown on gender.

The Labour Force Survey, compiled by the Office of National Statistics (ONS) in the United Kingdom, does collect gender-based data. However, their definition of forestry employment is more limited and excludes self-employed contractors, forest management work and recreational and conservation-related forestry jobs. Additionally, forestry industry statistics are now being shown as part of a more composite picture, which also includes agriculture, hunting and fishing. As such, more recent statistics are very ambiguous and fail to show the position of women in forestry employment. However, what the ONS statistics do show is that 11200 people worked in forestry in 1997, of which 30.4 percent were women (an increase of 7.4 percent since 1993).

The composite picture, in 2004, for forestry, agriculture, hunting and fishing estimates a total of 289000 men employed in these industries and 78000 women. Of these figures, 0.9 percent of men are employed and 6.1 percent self-employed, while 0.3 percent of women are employed and 3 percent are self-employed. There is an average differential in weekly gross earnings of $£ 26100$ in favour of men.

Despite the fact that it is no longer possible to identify forestry employment specifically, the data that are available strongly indicates a significant imbalance between women and men in these industries. This, combined with the 1997 statistics, gender-based research ("Professional Women Foresters in the British Forestry Industry" [Tomlin, 2001]), empirical and anecdotal evidence strongly points to a significant imbalance between the employment of men and women across the industry and at all levels.

\section{Public-sector/non-governmental organizations (NGOs)}

There is excellent information on gender representation for the British Forestry Commission. As of August 2004, the Forestry Commission employed a total of 3355 people, 30.6 percent of whom were women and 26.4 percent of these women were in forestry-related jobs ( 8.1 percent of the total workforce). Relatively few women are currently employed in forestry-related jobs at a senior level.

There is no definitive information available with regard to other public sector forestry roles (i.e. local authority councils, other government departments and agencies, etc.), although anecdotal evidence suggests that the number of women in forestry jobs is fairly low. 
Conversely, anecdotal evidence also suggests there is a higher level of representation of women in NGOs and that they are present at more senior levels of the organization, including the most senior/board-level jobs. However, actual statistical evidence on this is patchy and only indicative.

\section{Private sector}

As in the public sector, there is no definitive data available on the number of women employed in the private sector (including forest management, harvesting/timber sales, wood processing and haulage). Recent research and anecdotal evidence suggests that the numbers of women in these areas are very low.

A Forestry Commission survey of small- to medium-sized forestry businesses, including contractors, timber processing and haulage businesses, was undertaken in 1999/2000. The survey gathered information on the employment of 2950 workers in Britain. Only 16 percent of these were women, but information was not available as to the roles they were employed to do.

\section{Professional women foresters}

Information from the Institute of Chartered Foresters (ICF) in the United Kingdom suggests that there are significantly fewer women members than men: of the total 1072 male members, 748 are fully qualified members, while 324 are students or associates; of the total 95 female members, 47 are fully qualified, while 48 are students or associates.

However, not every professional forester is obliged to be a member of the ICF and these figures represent only a small proportion of those who are potentially eligible (both women and men). Similarly, anecdotal evidence suggests that many professional women have preferred not to join the ICF in the past because they perceive it as a male-dominated organization with predominantly male values and operating as an "old boys club".

Of those women who are members, 23.1 percent are in public-sector employment. The next highest figure is 15.8 percent, who are self-employed or forest owners and 15.8 percent employed by NGOs. Only 9.5 percent are in private-sector forest management companies, while 5.3 percent are in education and research. There are no women members employed in timber processing.

\section{Forestry education}

Information from the United Kingdom University Admissions and Clearing House (UCAS) shows a consistent trend, with women applicants for forestry-related courses being significantly less prevalent than those from men. Table 31 shows the figures for university applications by gender of forestry courses in the United Kingdom. 
Table 31: University applications by gender (2000-2003)

\begin{tabular}{lcccc}
\hline Gender & $\mathbf{2 0 0 0}$ & $\mathbf{2 0 0 1}$ & $\mathbf{2 0 0 2}$ & $\mathbf{2 0 0 3}$ \\
\hline Men & 102 & 108 & 119 & 95 \\
\hline Women & 10 & 11 & 16 & 14 \\
\hline
\end{tabular}

This situation seems to have been the case for at least the last 15 years and women, on average, make up only 6 to 8 percent of the class size.

A number of universities in the country offer "conversion" courses, enabling students to upgrade existing qualifications or convert to a forestry degree from another relevant discipline. Empirical evidence suggests that - relatively speaking - higher numbers of women with non-forestry qualifications apply to "convert" to a forestry Master of Science. In one university, these women made up a higher proportion of class size than those women who were studying for a Bachelor of Science degree straight from school.

Evidence from universities and colleges also shows that once in forestry courses women make very good students, with low dropout rates and good results. They are as successful as their male counterparts.

Recent research indicates that, on the evidence provided by nearly all participating universities and colleges, there was no difference between men and women graduates when it came to finding initial employment in forestry. Final year women students, who were interviewed as to their expectations for employment opportunities, confirmed this view.

There is no information, however, with regard to whether starting salaries for women are the same as those of men. There is no existing data available on the representation of women within the industry who hold other qualifications, for example, vocational qualifications, etc.

\subsubsection{What are the reasons for this picture?}

The indicative figures that are available, combined with qualitative research, strongly points to the fact that the underrepresentation of women in forestry is primarily due to discrimination. The age and length of service profiles of professional women foresters (where this is available), suggest that this was especially prevalent until about 15 years ago. Anecdotal and empirical evidence suggests that things have improved and are continuing to do so, yet many women still believe they are discriminated against (either explicitly or implicitly). This is something they have come to accept as inherent to working in the industry.

Research into other industries and in the British forestry industry itself suggests that organizational culture and value sets have a major impact on how recognition and reward are allocated. Often, subconsciously, senior managers seek a "fit" with the existing culture, which is frequently predominantly male. This stereotype pervades the whole industry and influences decisions on recognition, promotion and opportunities for training 
and development (Vinnecombe et al., 1999).

The culture in British forestry is also very "traditional" and "conservative" (words used by the women themselves in describing it), which has made it difficult to eradicate stereotypical roles. This "old boys club" mentality has, in the view of many women, made it very difficult for them to achieve the same levels of recognition and support.

Another key factor is the loss of women to the industry (and the difficulties of attracting them in the first place). This is exacerbated by the lack of "family-friendly" provisions and flexible working options. Many women are the main caregiver in the family and face significant challenges in balancing work and family commitments.

It has been suggested that there is much more scope in forestry employment for greater work flexibility than there used to be. However, employers still appear reluctant to consider it - possibly due to the perceived and real additional costs involved. Increasing legislation in this area is making the denial of flexible working patterns increasingly difficult to achieve.

Equal opportunities legislation (initially introduced in the United Kingdom in the mid-1970s) has had an impact on reducing explicit discrimination against women. There is also more recent evidence of increased commitment to addressing the gender imbalance, especially in the public sector (where there is ongoing government monitoring and target setting), and larger employers. However, much depends on how equal opportunities policies and practice are implemented at local level, by line managers. Anecdotal evidence strongly suggests there is a lack of consistency here and that - regardless of organizational policy - discrimination still can and does take place.

Another key issue that appears to be a barrier to women entering the industry is a lack of awareness as to what kind of jobs are available, combined with a somewhat negative image of industry employment (which tends to be stereotyped as "lumberjack" work). There is a general lack of knowledge and understanding of the opportunities the industry offers and this is as prevalent for men as women. Career advice on forestry jobs in schools and colleges is low. Where it is available, it can be negatively portrayed, as many career advisers do not perceive the industry as offering professional roles or good employment prospects.

Forestry is not therefore generally perceived as a real career option and many young people of either gender can face a barrier of opposition to any interest they may have in forestry employment.

In view of the fact that the prevailing image of the industry is harvesting and that very few women actually in forestry express interest in harvesting jobs, perhaps the lack of attraction to the industry is obvious. 


\subsubsection{What can be done to address the imbalance?}

The United Kingdom population demographics show that a significant proportion of the future labour market growth will come from women, particularly working mothers. Similarly, the number of white young men (the industry's traditional target employment market) will reduce. Such changes in the population will impact the way organizations recruit staff and the alternative sources they will be reliant on in the future.

However, in the United Kingdom, forestry is currently a shrinking industry with fewer jobs available. Addressing the imbalance will therefore be very challenging - even if there were a genuinely sustained commitment to do so - because it would take so long for women to achieve critical mass.

More visible senior-level commitment to change is required, across all sectors, to drive through changes in practice and, especially, culture. This may be more challenging in some sectors than others. Equal opportunities policies need to be implemented and monitored more rigorously, to ensure fairness and objectivity. Managerial commitment to facilitating better flexible working options could also be critical in retaining women (and men) to the industry.

It is also important for the industry to change the way it is perceived on the outside, thereby making it more attractive to men and women alike. Better quality career advice is needed and a more proactive approach will not only build an awareness of potential job opportunities, but also increase and improve overall awareness of this industry and its importance.

Work is also required with the media (especially the industry media) to present a more balanced picture of forestry work and show women in interesting, stimulating jobs (not just the occasional "token" women photograph). Again, this needs a more proactive approach.

These points are as valid for the attraction of men to the industry, as well as women and, as such, may be prove to be more successful in winning support and gaining influence and momentum. However, the United Kingdom forestry industry does appear to be declining at present - certainly in terms of employment opportunities - and it will be important to balance any potential increase in supply (of women applicants) with demand (availability of jobs).

It is also worth noting that there has been a growth of forest areas used for public access, leisure, sport and amenity use, rather than for timber production. This has been particularly prevalent within public sector and NGO-owned forests. This has resulted in a different range of jobs being developed to manage such changes in forest use (such as forest ranger, wildlife officers, etc.). These require different skill sets than the more traditional forestry roles - often skills in which women appear to excel (e.g. interpersonal and communication skills).

Anecdotal evidence suggests that there are increasing numbers of women working in these forestry-related roles. However, it is also suspected that pay in these areas is significantly below that of "traditional" forestry jobs. 


\subsection{THE UNITED STATES}

By Liz. Agpaoa

\subsubsection{The United States Forest Service Agency}

The Forest Service Agency is the largest federal agency in the United States government. The Forest Service's focus is forest management and its mission is to sustain America's forests and grasslands to benefit present and future generations.

The Forest Service Agency administers over 77902305 hectares of National Forest System lands for multiple use on a sustainable basis. A few of these multiple-use activities include forest management, recreation, wildfire risk reduction, watershed restoration, hunting, fishing and livestock grazing. The agency has been in existence for 100 years as a governmental entity.

In addition to the federal lands that the Forest Service actively manages, the agency also provides states, tribes, counties, cities and private landowners with technical and financial assistance through nonregulatory partnerships for over 202343650 hectares of non-federal forestlands. The agency operates the largest federal forestry research organization in the United States, with scientists carrying out basic and applied research in the biological, physical and social sciences.

\subsubsection{The Forest Service administrative units}

Federal Forest Service lands are largely concentrated in national forests and grasslands across the United States. More than 155 national forests (a large number of them located in the western United States) are located in nine separate regions of the United States in over 43 states.

The nine regions of the Forest Service, which all include national forests, are each managed by a regional forester. The average size of national forests are between 400000 and 1200000 hectares, and are managed by a forest supervisor. Each national forest is comprised of at least several ranger districts and managed by a district ranger. The Forest Service employs over 35000 employees for the management of the national forests, grasslands and research.

\subsubsection{Workforce objectives}

The Equal Employment Opportunity Commission (EEOC), a separate federal organization, guides the hiring and general employment of federal employees. The EEOC sets the regulation by which all federal agencies follow, including the objectives for hiring women and minorities.

The objectives for hiring women and ethnic minorities are provided by analyzing the Civilian Labor Force (CLF), which establishes the number of women or minorities working in specific jobs in the non-federal 
workforce nationwide. The data is collected and compiled each decade, with the most recent information available from the 2000 census. Federal agencies are evaluated annually on the progress they have made toward achieving diversity based on the data from CLF.

\subsubsection{Gender history}

Before 1960, relatively few professional women were employed in the Forest Service. Many of them at that time held traditional clerical positions. Because of increasing demand for forest products nationally, the workforce increased steadily during the 1970s and 1980s. Also in the 1980s, the multiple-use policies facilitated the hiring of professionals in the multiple science disciplines, which included foresters, engineers, biologists, hydrologists, geologists and anthropologists. The number of professional women in the Forest Service workforce increased significantly in 1980s and 1990s, and women were able to advance to key leadership positions as district rangers, forest supervisors and regional foresters, building critical mass.

\subsubsection{CLF comparisons with women in the Forest Service}

As part of the analysis and performance accountability, data were collected to monitor the progression toward achieving CLF objectives. In 2003, women comprised about 43 percent in the CLF, while they amounted to 39 percent in the Forest Service.

Figure 11: Women in the U.S. Forest Service and Civilian Labor Force (CLF)

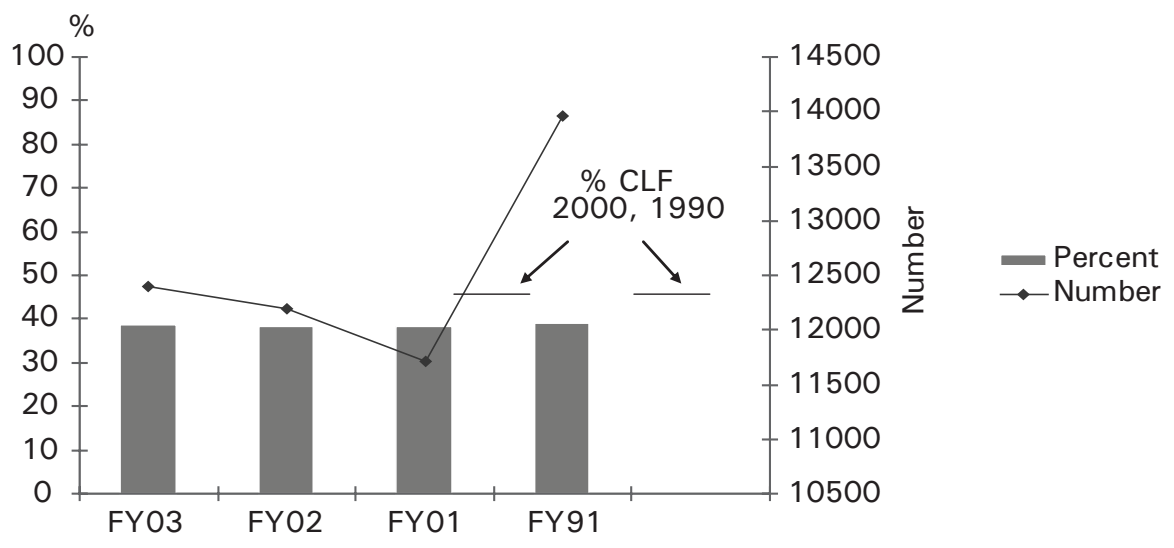

In 2000, women in professional positions in the CLF made up about 52 percent of the professional workforce, while in 2001 women in professional positions in the Forest Service amounted to 30 percent of the professional workforce.

In 2000, 55 percent of women held forester positions in the CLF, while in 2002 women foresters comprised about 25 percent in the Forest Service. 
Figure 12: Professional Female Foresters in the U.S. Forest Service and CLF

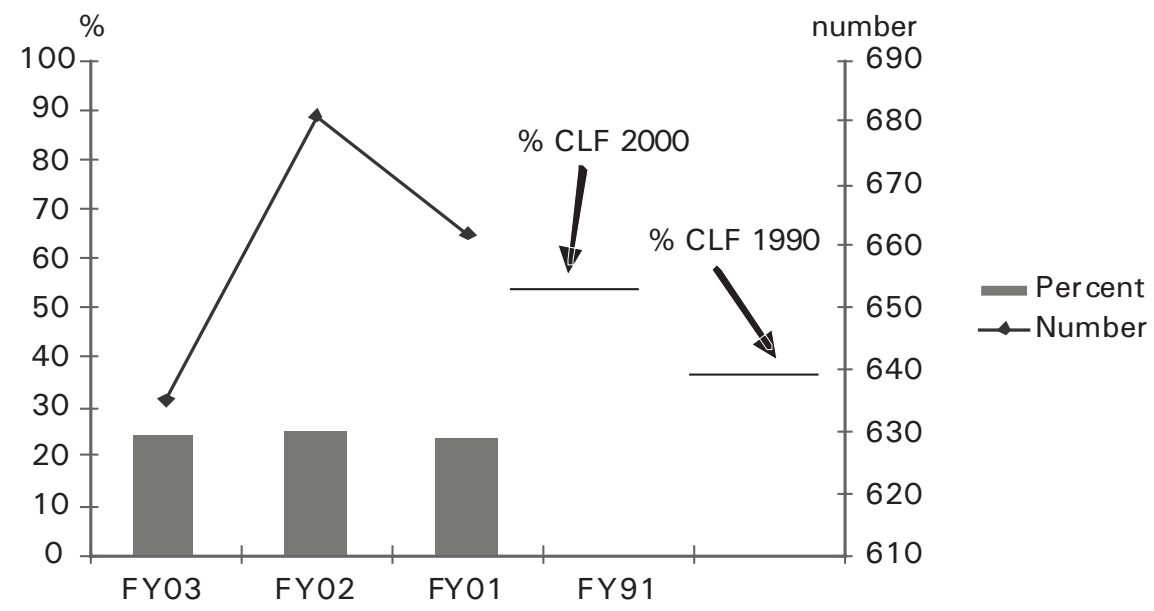

Figure 13: Professional Female Wildlife Biologists in the U.S. Forest Service and CLF

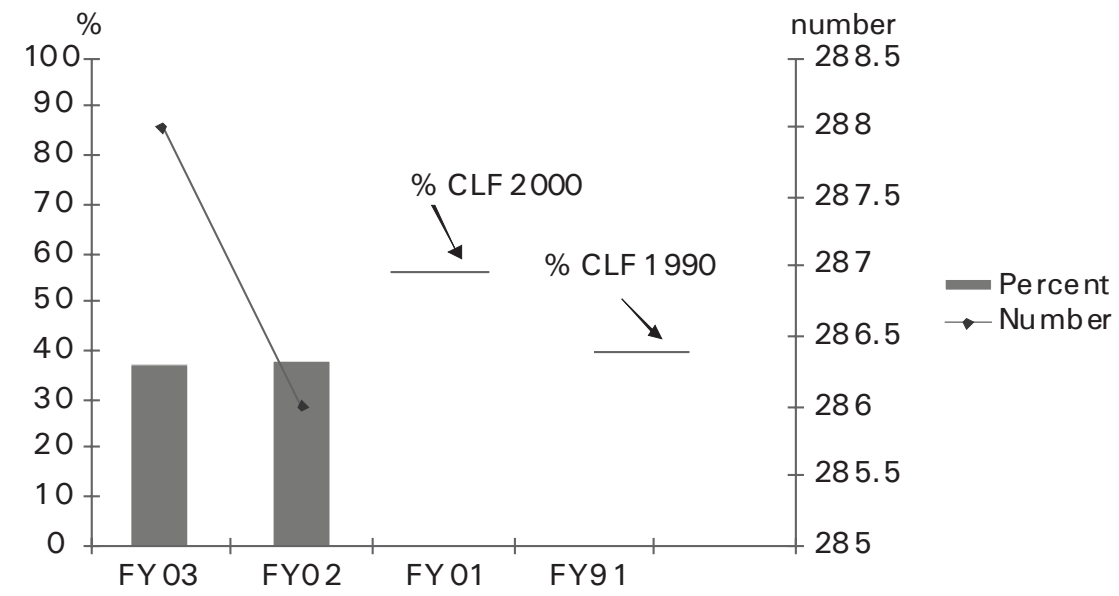

In 2000, women in wildlife biology positions in the CLF comprised 56 percent of the biologist workforce, while in 2002 women in wildlife biology positions of the Forest Service comprised 48 percent of the biologist workforce.

Figure 14: Professional Female Archaeologists in the U.S. Forest Service and CLF

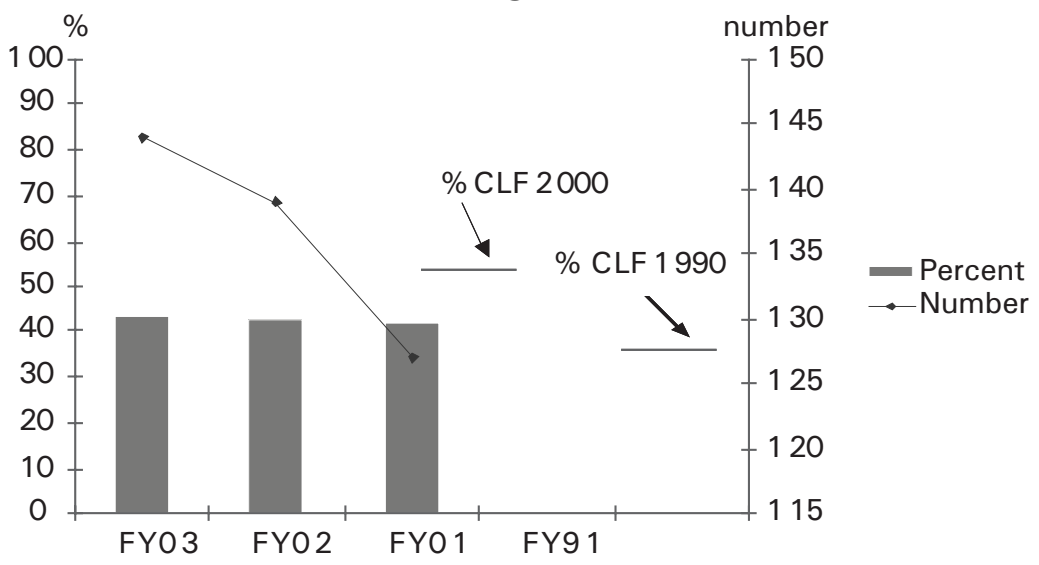

In 2000, women in archaeology positions in the CLF comprised 52 percent of the archaeology workforce, while in 2002 women in archaeology positions in the Forest Service comprised 42 percent of the archaeology workforce.

In 2000, women in hydrology positions in the CLF comprised 52 percent of the hydrology workforce, while in 2002 women in hydrology positions in the Forest Service comprised 38 percent of the hydrology workforce. 
Figure 15: Professional Female Hydrologists in the U.S. Forest Service and CLF

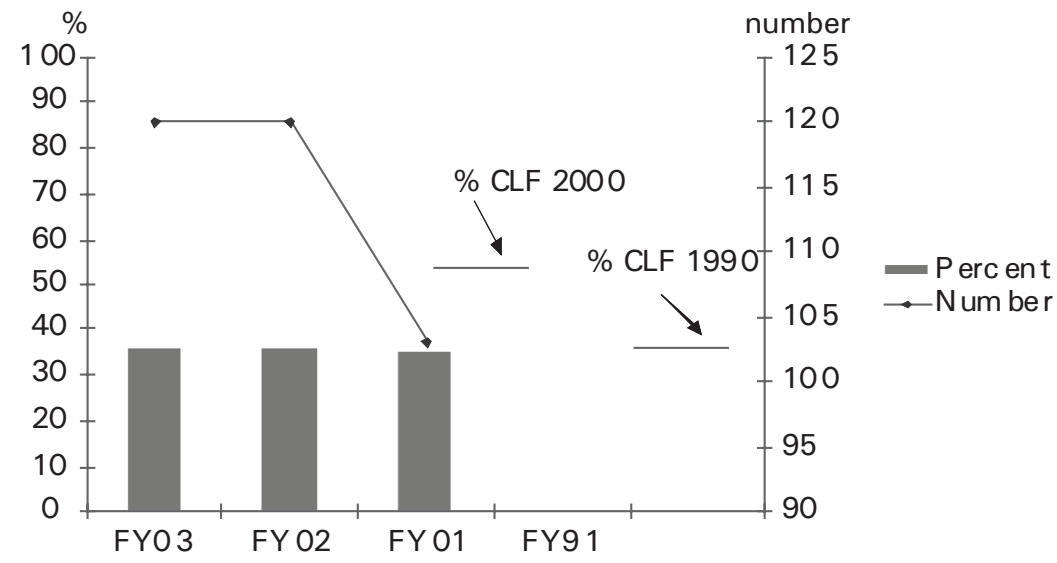

\subsubsection{Forest Service leadership positions}

Many women who entered the workforce in the 1970s and 1980s as foresters, biologists and other science-based specialists have advanced into leadership and management positions. Even though these positions include district ranger, forest supervisor and regional forester positions, they are classified under an administrative position series. The top hierarchy of the leadership positions in the Forest Service Agency is defined by the Senior Executive Series (SES). Of the 35 000-plus employees of the Forest Service, there are critically few SES leadership positions in the agency. However, in 2000 women in the CLF comprised 29 percent of the senior executive workforce and two years later that figure increased to 32 percent.

\subsubsection{Leadership at national headquarters}

Key positions at national headquarters of the Forest Service seem to be nearly balanced between men and women: the agency is headed by the chief of the forest service, with the associate chief being a woman - four deputy chiefs work under the chief, two of them women.

\subsubsection{Leadership across the United States}

As earlier noted, there are nine regions that are supervised by nine regional foresters. Two of the regional foresters are women, who manage some of the largest and complex regions of the country. The Pacific Northwest region is composed of 21 national forests with over 10.9 million hectares of land (27 000000 acres). The northern region is composed of 15 national forests with over 11.3 million hectares of land (28 000000 acres). The combined northern and Pacific Northwest regions comprise more than 20 million hectares of land (50 million acres).

\subsubsection{Women in key leadership positions}

In 2005, of the 155 forest supervisors who managed national forests, 33 were women who have management authority for more than 22.5 million hectares of land (55 million acres). In addition, 15 deputy forest supervisors are women, and women district rangers manage 140 ranger districts. 
The progress for increasing the diversity of women in the Forest Service during the past three decades has been steady. In the 1980s, the leadership in the Forest Service aimed not only to increase the overall numbers of women in the agency, but also worked consciously to ensure that women were mentored toward leadership positions within the agency. In the late 1980s and early 1990s, some advancement had been made as women began to be hired to work in nontraditional positions as rangers and forest supervisors.

\subsection{REVIEW OF GENDER SITUATION IN OTHER COUNTRIES}

\section{By Anna Springfors and Gun Lidestav}

This subchapter provides a brief account of (published or personal communication) of the gender situation in the forestry sector of Bulgaria, Czech Republic, Cyprus, Portugal, Serbia and Montenegro, Switzerland and Turkey.

Bulgaria $^{2}$ has about 15100 men and 5700 women employed in the forestry sector, with women representing 27 percent of the total. Unsuitable working conditions, such as isolated and remote work that is difficult to combine with family responsibilities and issues with the physical requirements and technical knowledge that women often lack, are some explanations for the low number of women employees who work in the sector. However, because forest equipment is being increasingly modernized, these obstacles should diminish and women will have a better chance to enter the sector. The increased focus on ecology might also attract more women. The institute for forestry in Sofia, for example, has about 40 percent female students, and some research institutes in the country have more than 50 percent women on its staff.

In the Czech Republic ${ }^{3}$ women constitute a significant share of the employees in both state enterprises as well as forestry institutes. About 900 women are employed in state enterprises, which correspond to 24 percent of the total workforce; in leadership functions (chief of staff), the proportion of women is 46 percent. Moreover, there are about 300 women in the Forestry Management Institute and the Forestry and Game Management Research Institute, which represents 50 percent of the total number of employees. However, in top-level positions (chief of staff), less than 10 percent are women. In the past 25 years, between 15 to 18 percent of graduate students (M.Sc.) in forestry have been women. Since 1998, of the graduate students in wood technology, less than 10 percent have been women. The share of young women who study forestry in secondary schools has been increasing since 1990. However, it is difficult to find work in the forest sector because there are too many graduates in forestry; the situation, though, is the same for women and men.

\footnotetext{
${ }^{2}$ Janka Takeva. 2001. Conditions de travail des femmes dans la forestière en Bulgarie. Seminar proceedings (Joint FAO/ECE/ILO Committee on Forest Technology, Management and Training) Women in Forestry - Strategies to Increase Women's Participation in the Forestry Sector in Europe and North America, Viseu, Portugal, 2-6 April 2001.

${ }^{3}$ Dana Koderova, Forest State Service.
} 
In Cyprus, ${ }^{4} 2$ percent of the workforce is employed in the forest sector. The presence of women is low, as the work has been socially considered, even until now, as a "male" sector, at least in certain fields of forestry. The employment of women is restricted only in the low ranks of the sector's pyramid, as a labour force for certain forestry works such as forestry nurseries, afforestation/reforestation, maintenance of plantations, etc. The ratio of women in the labour force to the total labour force employed by the Department of Forests is about 13.5 percent. Portugal has a considerable number of women in the forestry sector. ${ }^{5}$ One of the reasons is that Portugal has always been a country with high emigration rates - when men leave, the women remain behind to do the work. Unlike many other countries, most women kept their jobs even when the men returned. Mechanization in forestry jobs has not reduced the amount of work for women because men who operated the equipment lost their jobs while women remained with their traditional tasks. The number of men and women with a diploma from a forestry school, either from technical schools or from universities, is about the same, mainly because Portugal's forestry engineering courses were one of the first to emphasize environmental concerns and the first to deal with ecology. For example, in the Direction General of Forests, 62 percent of forestry engineers are women, and 40 percent of heads of departments are women. Programmes for forest watchers, who are forest workers skilled in preventive silviculture for the protection of forest against fires, has a participation rate of 30 percent women, and there are teams that only consist of women.

"Serbiaforests" is the public forestry enterprise in Serbia and Montenegro ${ }^{6}$ that manages and controls the largest amount of forestlands in the country; it also has the largest number of employees, with 18 percent of employees being women. More than half of the women professionals have educational qualifications other than forestry or secondary school, and though some of these women have been appointed manager none has reached the top levels of the organization. With regard to forestry schools, at the Faculty of Forestry at the University of Belgrade, 57 percent of the student body were male and 42 percent female in the period from 1991 to 2001. In the same period, 63 percent of the graduates were male and 38 percent female. Even though a high percentage of students do not finish their education, there are comparatively more female than male students who drop out.

In Switzerland, ${ }^{7}$ women represent less than 20 percent of forestry engineers. The amount of women

\footnotetext{
${ }^{4}$ Alexandrou Charalampos, Department of Forests, Cyprus.

${ }_{5}^{5}$ Sa Almaida A. and Franqueira B. 2001. Women's attitudes towards forests: Southern Portugal. Seminar proceedings (Joint FAO/ECE/ ILO Committee on Forest Technology, Management and Training) Women in Forestry - Strategies to increase women's participation in the forestry sector in Europe and North America, Viseu, Portugal, 2-6 April 2001.

${ }^{6}$ Stefanovic, B. Ivanovic, G. and Stefanovic, B. 2001. The specific role of women in the forestry sector - analysis and perspective in public enterprise "Serbiaforests" in Yugoslavia, Seminar proceedings (Joint FAO/ECE/ILO Committee on Forest Technology, Management and Training) Women in Forestry - Strategies to Increase Women's Participation in the Forestry Sector in Europe and North America, Viseu, Portugal, 2-6 April 2001.

${ }^{7}$ Claire-Lise Suter Thalmann, Forest Service, Switzerland.
} 
in the forest service is about 2 to 3 percent. At university level, about 15 percent of female students are enrolled in forestry programs. At present, there are no women at the professorial level and only a few are female lecturers. Interviews held with female and male forestry engineers found that the "natural" difference between the sexes (physical strength) is irrelevant in the work. The women believed that because the professional culture in forestry is based on "masculinity", they have to neutralize their gender in order to be accepted as competent in their profession. State forestry agencies continue to be the least accessible field for women, while self-employment as an engineering consultant or researcher offer better opportunities. On the structural level, combining employment and motherhood is a significant problem due to the lack of childcare facilities. The most common solution for resolving this dilemma is working part-time, thus reducing women's career opportunities.

In Turkey, ${ }^{8}$ women have traditionally played an important role in nursery, plantation, harvesting and silviculture practices, but the number of women choosing forestry engineering is low compared with men. In 1998, there were about 20 percent female and 80 percent male students enrolled in forestry courses. Even with the steady increase of female graduates from forest faculties, there is still widespread belief that forestry work is unsuitable for women because of difficult working conditions. In reality, there are only certain situations that require these working conditions, such as forest firefighting. A survey taken among female forestry engineers has shown that many women foresters (38 percent) were unsatisfied with their job, citing that they received less important work than their male colleagues and were not given the opportunity to work in areas of interest. Female foresters who had worked for more than six years were less satisfied then those who had worked for a few years. Married women foresters had a higher degree of dissatisfaction owing to problems of coordinating their work with their family responsibilities. Of the married female forestry engineers, 64 percent were married to another forestry engineer. When asked about the first reaction from colleagues, workers and villagers upon meeting a female forestry engineer, 68 percent said that they had a negative experience. Female foresters who had been working more than five years at the same place were asked about the impression after five years and only 14 percent thought that it still negative. The female foresters want to be treated equally just as their male colleagues are, regardless of their sex or family status. They believe they are as capable as their male colleagues. Interviews with managers of women foresters revealed that managers are generally pleased with their female colleagues, considering both their capability and ability of working in the office and in the forest.

${ }^{8}$ Bahar, B. 1999. Forestry and Women in Turkey. Proceedings from Symposium on Women and Forestry, Lillehammar, Norway, 12-15 August 1999. 


\subsection{SUMMARY}

In summary, it is apparent that existing data sources provide only indications and insights of the overall picture of gender structures in organizations. In a number of countries, national- level industry statistics do not differentiate on the basis of gender. Even where they do, they are often encompassed in a wider category of land-based industries.

Where good data are available - usually from government and public-sector organizations -there is usually more emphasis on adhering to legislation and government policy and targets. There are still, therefore, gaps in our understanding of gender structures across the forestry supply chain within Europe and North America, especially in the private sector and the SME contracting and self-employed labour force.

A number of countries have addressed the issue of gender and forestry. Sweden has approved a policy that encourages the inclusion of gender considerations affecting recruitment of women in forestry. The Norwegian government strengthened its focus on gender aspects 20 years ago by developing policy and taking action to fulfil the policy objectives. In the late 1980s and early 1990s, to increase women in the forestry sector, new tools were created. However, substantial changes in the representation of women in forestry have not been evidenced. In Finland, younger women are beginning to enter the forestry workforce in more equitable numbers, although a higher percentage of them are taking non-permanent forestry positions. In the United States, women are steadily increasing their presence in the forestry workforce, which also includes leadership positions.

Yet there continues to be a lack of data and information related to gender in the forestry sector; the limited information is a matter of concern. In the German forestry sector, for example, the existing statistics show that women are poorly represented in forestry. The United Kingdom has little detailed data available on women working in the British forestry industry. Armenia has an overall lack of professional foresters and forest technicians and information on women in forestry is absent. The statistics in Poland show substantial differences in earnings between women and men. Women in the forestry sector are generally represented in administrative positions.

The industry faces a very real challenge if it is genuinely serious about counterbalancing the currently male-dominated workforce. Discriminatory practices aside, the industry does not appear to be one that attracts women, due to the stereotyping of roles and the negative image it has in some parts of the world. Additionally, there appears to be little awareness and knowledge of what forestry careers offer, especially at the stage when schoolchildren are making important decisions about what subjects to study. Career advice on the industry also appears to be scarce. 
A further complication is that, in some countries the number of jobs in forestry are reducing - thereby offering fewer opportunities and significantly slowing down the opportunity to redress the balance between men and women.

It is clear that, despite a wealth of evidence to the contrary, there are deeply rooted cultural and societal values that continue to blind senior decision makers - almost exclusively men - to the significant benefits to be achieved for their organizations (and society as a whole) through more balanced gender structures.

In tackling such strongly held discriminatory beliefs, the weight of objective evidence is not enough and much more effort is required to address the cultural value sets, which exist across the industry and currently hinder women from being able to compete on the same level as men. 



\section{GENDER STRUCTURES IN FAMILY FORESTRY}

\subsection{INTRODUCTION}

By Berit Sanness and Natalie Hufnagl

\subsubsection{Ownership structure in the ECE area}

According to the latest UN/ECE/FAO statistics, family forest ownership plays a significant role in Europe (54.8 percent), Japan (59 percent), North America: Canada and the United States (36.8 percent) and New Zealand (30.6 percent), see Table 32.

Table 32: Ownership structure in the ECE area

\begin{tabular}{lcc}
\hline Region & $\begin{array}{c}\text { Public ownership } \\
\mathbf{( \% )}\end{array}$ & $\begin{array}{c}\text { Private ownership } \\
\mathbf{( \% )}\end{array}$ \\
\hline Europe & 45.2 & 54.8 \\
15 European Union countries & 29.8 & $\mathbf{7 0 . 2}$ \\
\hline CIS & 100.00 & 0 \\
\hline North America & 63.2 & 36.8 \\
Canada & 89.7 & 10.3 \\
United States of America & 33.3 & $\mathbf{6 6 , 6}$ \\
\hline Other TBFRA countries & & 27.0 \\
Australia & 73.0 & $\mathbf{5 9 . 0}$ \\
Japan & 41.0 & 30.6 \\
New Zealand & 69.4 & $\mathbf{1 9 . 3}$ \\
\hline Total & $\mathbf{8 0 . 7}$ & \\
\hline
\end{tabular}

Source: TBFRA, 2000.

The Temperate and Boreal Forest Resources Assessment (TBFRA) area includes Europe, North America, Japan, Australia, New Zealand and the Commonwealth of Independent States (CIS). The highest share of private ownership within the TBFRA area is in Europe, at 55 percent.

In the European Union, about 60 percent of forests and forestland are owned by individuals (CEPF, 2000) and called "family forestry". According to data from European and American forest owners' organizations, the size of the forest holdings are from 0.5 hectares up to more than 1000 hectares. Within the European Union, families own approximately 12 million forest holdings, while in the United States the number is closer to 10 million. In addition, Canada has about 0.5 million family-owned forest holdings (CEPF, CFWO and ATFS, 2002). However, the total number of forest owners in all these countries is higher than these numbers indicate, as many forest holdings are often owned together by two or more people. For example, in Norway, this represents 80 percent of cases (Strupstad, 1991). 


\subsubsection{Lack of data}

On behalf of the Team of Specialists, the European Forest Owners' Organisation (CEPF) distributed questionnaires to its members in autumn 2004, but the responses failed to provide concrete figures regarding gender structure in their organizations. In February 2006, a new questionnaire was distributed to some of the member organizations and to the North American organizations as well, but again there was limited response. The Team understands the lack of response as a result of missing data on the gender structure within the organizations.

Nevertheless, data from some countries do exist and therefore the contributions that follow may be regarded as examples of gender structures in family forestry as well as in forest owners' associations.

\subsection{GENDER STRUCTURES IN SWEDISH FAMILY FORESTRY}

\section{By Gun Lidestav}

\subsubsection{Introduction}

In family forestry (closely connected to family farming), traditional ideas of gender in terms of women's and men's inheritance positions, division of work and influence, and participation in management prevail to a large extent (cf. Haugen, 1994; Brandth, 1995; Brandth and Haugen, 1998; Flygare, 1999; Lidestav, 2001). This chapter takes a more complete look at Sweden's situation. The first section analyses women's and men's access to forest property by inheritance, while the second section compares general ownership features and involvement in management and decision-making between men and women. Finally, the last section examines women's representation in forest owners' associations.

\subsubsection{Gender and inheritance in Swedish family forestry}

Women in Sweden, as far as known, have never been excluded from the right to inherit land (Sawyer, 2003). However, their rights of disposition to the land, and the profits from it, was not fully and legally recognized until half a century ago (Niskanen, 2001). The husband's exclusive right to manage his wife's land, as the general rule before the introduction of the new marriage act in 1921, was due to certain provisional regulations regarding marriages predating 1921 and left to function until 1950.

Fifty years later, there still is an asymmetrical distribution of women's and men's forest ownership when analysing the national register of forest owners and forest estates (Skogsdataregistret). Differences are displayed in terms of property size as well as ownership category (Table 33). The number of male owners amount to 202534 , while the number of female owners totals 119705 . When a forest property is owned by two or 
more persons of different sex, women amount to almost half of the ownership irrespective of property size.

On the other hand, if a woman is a single owner or if she owns the property together with other women, the proportion of female ownership decreases as the size of the property increases. Women's ownership of forestland is, in other words, characterized by partner ownership with at least one man.

Table 33: Proportion of female forest owners in different ownership categories (\%)

\begin{tabular}{lcccc}
\hline Forest size & $\begin{array}{c}\text { Singly } \\
\text { owned forests }\end{array}$ & $\begin{array}{c}\text { Owned with one or more } \\
\text { persons of same sex }\end{array}$ & $\begin{array}{c}\text { Owned with one or more } \\
\text { persons of different sex }\end{array}$ & All \\
\hline 5 to 49 ha & 26.0 & 30.4 & 48.5 & 37.2 \\
\hline 50 to 399 ha & 19.5 & 25.7 & 49.1 & 37.0 \\
\hline 400 ha or more & 17.3 & 18.6 & 48.3 & 37.7 \\
\hline All & 24.1 & 28.5 & 48.8 & 37.1 \\
\hline
\end{tabular}

Source: Skogsdataregistret, Statistics Sweden, 1994.

By analyzing data collected in the survey (Lidestav, 2003), the number of people that have inherited forestland from their parents or relatives was estimated to be about 135000 persons (67 percent male) and 71000 (59 percent female). The male owners acquired 92167 management units, and the female owners 37538 units. Thus, a majority of women have become forest owners by acquisition of property from their parents or relatives and not through marriage via the husband's family. Among male owners, acquisitions from their own family or relatives are even more commonplace.

Additionally, as presented in Table 34, it is more common that male owners are single owners (38 percent) compared with female owners (24 percent). The proportion of women among single owners is estimated to be 24.8 percent, which is similar to the one reported in the previous analysis of "Skogsdataregistret" (Table 33). Half of these women and a third of these men own properties together with siblings or other relatives and women are more likely to own together with men than the other way around. The proportion of persons who own together with a spouse is estimated to be 24 percent for men and 22 percent for women. However, when comparing sample records of ownership constellation with the answers given by the respondents, a significant discrepancy is found. About 14400 (10.6 percent) of the male owners who report that they own the forestland together with their wife are registered as single owners. Corresponding figures for female owners are 1300 (1.8 percent). This discrepancy is interpreted as: when women are single owners they usually own the estate as personal property while men's ownership more often is held jointly with his wife (Lidestav, 2003). 
Table 34: Proportion of male and female owners on forest properties acquired via their own parents / relatives by ownership constellation $(n=980)$

\begin{tabular}{lcccc}
\hline Type of ownership & $\begin{array}{c}\text { Men, } \\
\text { row percent* }\end{array}$ & $\begin{array}{c}\text { Women, } \\
\text { row percent }\end{array}$ & $\begin{array}{c}\text { Men, column } \\
\text { percent** }\end{array}$ & $\begin{array}{c}\text { Women, column } \\
\text { percent }\end{array}$ \\
\hline Own alone & $75.2 \mathrm{a}$ & $24.8 \mathrm{~b}$ & $38 \mathrm{a}$ & $24 \mathrm{~b}$ \\
\hline Own together with spouse & $67.7 \mathrm{a}$ & $32.3 \mathrm{~b}$ & $24 \mathrm{a}$ & $22 \mathrm{a}$ \\
\hline Own together with siblings/relatives & $56.6 \mathrm{a}$ & $43.4 \mathrm{~b}$ & $34 \mathrm{a}$ & $50 \mathrm{~b}$ \\
\hline \multicolumn{1}{c}{ whereof with same sex } & $62.6 \mathrm{a}$ & $37.4 b$ & $14 \mathrm{a}$ & $16 \mathrm{~b}$ \\
\hline \multicolumn{1}{c}{ whereof with different sex } & $53.1 \mathrm{a}$ & $46.9 \mathrm{~b}$ & $19 \mathrm{a}$ & $33 \mathrm{~b}$ \\
\hline $\begin{array}{l}\text { Own together with non-relatives or other } \\
\text { combination }\end{array}$ & $62.3 \mathrm{a}$ & $37.7 \mathrm{~b}$ & $3 \mathrm{a}$ & $3 \mathrm{a}$
\end{tabular}

* Adding the first line on the first row and the second row equals $100 \%$.

** Adding the figures in this column equals $100 \%$.

1) Significant $(p<0.05)$ differences between the two or three columns are indicated by the letters $a$ and $b$.

Source: Lidestav, 2003.

It is to be noted that the data cannot determine how many of the 71000 female owners have competed with a brother, or another party, for property acquisition. What is known is that at least 23200 women have a brother or male relative as partner owner. It is likely that there are a number of women who own forestland alone, or together with another woman, who have also outrivaled a brother. However, such information was not included as one of the questions in the survey. Comparing some other variables, however, reveals interesting information. Regarding mean age and the married proportion of respondents, there are no significant differences between men and women (Table 35). This indicates conformity between the sexes regarding generational belonging and family patterns. On the contrary, the mean size of women's forest property is lower, and the average number of owners per estate is higher. Female owners are less often residents on the estate or agricultural farmers. Furthermore, they have more often acquired the forestland as a gift or by inheritance, while the male owners more often have bought the property from their parents.

Although there are a significant number of women who are forest owners in spite of brothers or other male relatives in the family, it can be stated that gender has an impact on:

- Whether an heir has taken over the family forest farm or not;

- Whether the forest estate is singly or jointly owned; and

- The size of the property.

In spite of the asymmetric ownership exposed by the analyses, viewed separately or in conjunction with each other, it has become evident that sisters can compete with a brother in contemporary family forestry, even though brothers seldom are outrivaled. Joint ownership by two or more siblings may be regarded as a convenient solution to both the traditional problem of not splitting up the holding as well as modern demands for gender equality. 
Table 35: Descriptive accounts of owners and forest estates acquired via parents or relatives

\begin{tabular}{lll}
\hline Descriptive information & Men & Women \\
\hline Mean size, hectare & $58.2 \mathrm{a}$ & $49.4 \mathrm{~b}$ \\
\hline Mean age, year & $53.0 \mathrm{a}$ & $52.3 \mathrm{a}$ \\
\hline Proportion with spouse, $\%$ & $79.9 \mathrm{a}$ & $82.5 \mathrm{a}$ \\
\hline Proportion resident at the estate, $\%$ & $51.0 \mathrm{a}$ & $31.3 \mathrm{~b}$ \\
\hline Proportion with agriculture on the estate, $\%$ & $34.2 \mathrm{a}$ & $15.8 \mathrm{~b}$ \\
\hline Number of owners on the estate, mean & $1.47 \mathrm{a}$ & $1.89 \mathrm{~b}$ \\
\hline Forestland acquired by inheritance/gift/last will, $\%$ & $41.5 \mathrm{a}$ & $60.9 \mathrm{~b}$ \\
\hline Forestland acquired, purchased from relatives, $\%$ & $58.5 \mathrm{a}$ & $39.1 \mathrm{~b}$ \\
\hline
\end{tabular}

1) Significant $(\mathrm{p}<0.05)$ differences between the two or three columns are indicated by the letters a and b. Source: Lidestav, 2003.

\subsubsection{Comparing male and female owners}

If forest owners have acquired property from means other than their own relatives, e.g. their spouse's relatives or bought on the market, are included in the analysis, it is found that male ownership is twice that of female ownership and that the mean size of male forest holdings is also somewhat larger (see Table 36). No difference in marriage frequency was found, but women have more often than men become owners by attainment from spouses' parents.

Consequently, men have more often attained the forest holding from their own parents, are more often single owners, and wish to a higher extent that one child will take over the property.

Significant differences regarding self-employment are demonstrated, particularly regarding practical work and most of all in harvesting and extraction. While most men perceive themselves as bearing main responsibility for decision-making and practical work, most women state that they share the main responsibility with their husbands, partner owners, or even have transferred the main responsibility to them. Although women, to a lesser extent, reside on the forest holding, they value housing higher than men. They have a higher appreciation for firewood/timber for household use, collecting berries and mushrooms, and outdoor life/ recreation (Table 37).

With regard to other assets, such as forest income, hunting and fishing, contact with native locality, keeping up with a forest farmer tradition, significant differences were not found. A significant higher proportion of male owners state that they are not willing to put aside any productive forestland for nature conservation purposes without compensation (32.0 percent resp. 23.0 percent).Although most men do not consider themselves as forest farmers, an even lower proportion of women do so. In conclusion, forest owner masculinity is at present very different from forest owner femininity and thereby also the identities and social practices that appear in contemporary family forestry (Lidestav and Nordfjell, 2005). 
Table 36: Comparison of male and female forest owners regarding general ownership features and variables with relevance on gender, inheritance and management

\begin{tabular}{|c|c|c|}
\hline Ownership features & Men & Women \\
\hline Mean size of the forest holding, hectare & $58.2 \mathrm{a}$ & $49.4 b$ \\
\hline Mean age of the owner, year & $53.2 \mathrm{a}$ & $52.6 \mathrm{~b}$ \\
\hline Distribution of owners, $\%$ & 62.9 & 37.1 \\
\hline Residing on the forest holding, $\%$ & $52.1 \mathrm{a}$ & $44.2 b$ \\
\hline Married/partnership, $\%$ & $81.2 \mathrm{a}$ & $83.0 \mathrm{a}$ \\
\hline Having children, $\%$ & $81.1 \mathrm{a}$ & $87.3 \mathrm{~b}$ \\
\hline Single ownership, $\%$ & $33.6 \mathrm{a}$ & $20.2 b$ \\
\hline Ownership with spouse, $\%$ & $30.5 \mathrm{a}$ & $38.7 b$ \\
\hline Ownership with relatives, $\%$ & $31.9 \mathrm{a}$ & $36.3 \mathrm{a}$ \\
\hline Considering self as forest farmer, $\%$ & $37.6 \mathrm{a}$ & $7.7 \mathrm{~b}$ \\
\hline Have attained the forest holding from their parents, $\%$ & $67.0 \mathrm{a}$ & $59.2 b$ \\
\hline Have attained the forest holding from their spouse's parents, $\%$ & $6.4 \mathrm{a}$ & $16.0 \mathrm{~b}$ \\
\hline Desiring one child to take over the forest holding, $\%$ & $34.6 \mathrm{a}$ & $26.9 \mathrm{~b}$ \\
\hline Desiring more than one child to take over the forest holding, $\%$ & $26.5 \mathrm{a}$ & $30.8 \mathrm{~b}$ \\
\hline $\begin{array}{l}\text { Considering self as main person responsible for decision-making, } \\
\text { resp. practical work } \%\end{array}$ & $\begin{array}{l}64.1 \mathrm{a} \\
65.1 \mathrm{a}\end{array}$ & $\begin{array}{c}13.5 b \\
6.3 b\end{array}$ \\
\hline $\begin{array}{l}\text { Considering self, together with spouse, responsible for decision-making, resp. } \\
\text { practical work } \%\end{array}$ & $\begin{array}{l}15.9 \mathrm{a} \\
23.4 a\end{array}$ & $\begin{array}{c}40.4 b \\
8.5 b\end{array}$ \\
\hline $\begin{array}{l}\text { Owners considering self and partner-owner responsible for decision-making } \\
\text { resp. practical work } \%\end{array}$ & $\begin{array}{l}7.7 \mathrm{a} \\
6.0 a\end{array}$ & $\begin{array}{r}6.2 \mathrm{a} \\
3.2 b\end{array}$ \\
\hline Considering spouse responsible for decision making, resp. practical work, $\%$ & $0.0 \mathrm{a}$ & $\begin{array}{l}16.7 b \\
32.4 b\end{array}$ \\
\hline $\begin{array}{l}\text { Owners considering partner-owner responsible for decision-making resp. } \\
\text { practical work, } \%\end{array}$ & $\begin{array}{l}7.2 \mathrm{a} \\
7.1 \mathrm{a}\end{array}$ & $\begin{array}{l}14.1 b \\
12.2 b\end{array}$ \\
\hline Self-employed in harvesting, $\%$ & $58.2 \mathrm{a}$ & $3.1 \mathrm{~b}$ \\
\hline Self-employed in extraction, $\%$ & $42.4 \mathrm{a}$ & $2.0 \mathrm{~b}$ \\
\hline Self-employed in planting, $\%$ & $61.6 \mathrm{a}$ & $34.9 \mathrm{~b}$ \\
\hline Self-employed in cleaning, $\%$ & $69.2 \mathrm{a}$ & $12.4 \mathrm{~b}$ \\
\hline Self-employed in planning of future measures, $\%$ & $60.6 \mathrm{a}$ & $29.1 b$ \\
\hline Self-employed in bookkeeping, $\%$ & $50.3 \mathrm{a}$ & $32.7 \mathrm{~b}$ \\
\hline Self-employed in tax declaration, $\%$ & $40.2 \mathrm{a}$ & $32.4 \mathrm{~b}$ \\
\hline Self-employed in contacts with timber merchants, forestry service, etc., $\%$ & $69.9 \mathrm{a}$ & $19.9 \mathrm{~b}$ \\
\hline
\end{tabular}

1) Significant $(p<0.05)$ differences between the two or three columns are indicated by the letters a and $b$. Source: Lidestav and Nordfjell, 2005.

The fact that 37 percent of all owners are women and that 59.2 percent of them have attained the forest property from their parents, compared with 67.0 percent for men, certainly shows that gender has an impact on inheritance position. On the other hand, female owners' low participation in management activities and their less frequent perception as forest farmer do not seem to disqualify women as heirs of forest properties. There are differences in ownership patterns between female owners and male owners, through the setting up of different management and inheritance conditions for the individual owner. Women, who often share ownership 
with relatives, are also more interested in allowing more than one child to take over the forest holding. Further, the entrance to forest ownership by marriage does vary between male owners and female owners, indicating the impact of marriage as an institution.

Table 37: Forest owners' valuation of different goods and land for nature conservation, by mean value $(1=$ No relevance, $5=$ very important $)$

\section{Forest owners' valuation}

Male owners

Female owners

(by mean value, or $\%$ where indicated)

\begin{tabular}{lll}
\hline Forest income & $3.2 \mathrm{a}$ & $3.2 \mathrm{a}$ \\
\hline Hunting and fishing & $2.7 \mathrm{a}$ & $2.7 \mathrm{a}$ \\
\hline Berries and mushrooms & $2.3 \mathrm{a}$ & $3.0 \mathrm{~b}$ \\
\hline Firewood and timber for household use & $3.5 \mathrm{a}$ & $3.8 \mathrm{~b}$ \\
\hline Housing & $3.4 \mathrm{a}$ & $3.5 \mathrm{~b}$ \\
\hline Outdoor life and recreation & $3.6 \mathrm{a}$ & $3.8 \mathrm{~b}$ \\
\hline Keeping contact with native locality & $3.1 \mathrm{a}$ & $3.1 \mathrm{a}$ \\
\hline Upkeep of forest farmer tradition & $3.2 \mathrm{a}$ & $3.2 \mathrm{~b}$ \\
\hline $\begin{array}{l}\text { o of owners that are not willing to put aside any productive } \\
\text { forestland for nature conservation purposes }\end{array}$ & $32.0 \mathrm{a}$ & $23.0 \mathrm{~b}$
\end{tabular}

Source: Lidestav and Nordfjell, 2005.

\subsubsection{Women's representation in forest owners' associations}

In Sweden, almost 90000 (or 38 percent) of small forest estates are associated in one of four major forest owners' associations. One of the associations runs three pulp mills in Sweden (and two in Norway). In total, the associations manage just over 20 sawmills. In 2003, the pulp mills produced 2 metric tonnes of pulp whereas sawmills produced 1.6 million $\mathrm{m}^{3}$ (Berlin et al., 2006). The probability of being in an association is somewhat higher if the owner is male rather than female, 50.3 percent for males compared with 44.5 percent for females (Lidestav and Nordfjell, 2005). The four associations each have an elected board, and they are further divided into smaller districts (each with an elected board) that consist of 150 to 300 owners. Although the number of women elected have increased substantially during recent years, women's representation is still low (Table 38).

Table 38: Women's representation in forest owner association boards and district boards, 2006

\begin{tabular}{lcc}
\hline Forest owner association & General board level (\%) & District board level (\%) \\
\hline Norra Skogsägarna & 15 & 15 \\
\hline Norrskog & 8 & 20 \\
\hline Mellanskog & 20 & 17 \\
\hline Södra Skogsägarna & 13 & 16 \\
\hline
\end{tabular}




\subsection{NORDRHEIN-WESTFALEN, GERMANY}

By Renate Spaeth

\subsubsection{Introduction}

Nordrhein-Westfalen (NRW) is one of 16 Laender (states) forming the Federal Republic of Germany. Nordrhein-Westfalen is located in the northwest of the country and borders the Netherlands, Belgium and Luxembourg; it has the highest population of all the other states, with more than 18 million inhabitants. The region's forestland amounts to 915800 hectares, 25 percent of its surface. Private forest owners own about 592900 hectares of land, equivalent to about 65 percent of forestland.

\subsubsection{Survey concerning forest owners' structure and motivation}

In 2000, the Private Forests Owners' Association of NRW launched a study, which the state forest administration of NRW funded, to examine the structure and the motivation of private forest owners. The study was based on questionnaires that authors Becker and Borchers sent out to forest owners, in which they were also asked to indicate their gender. The results, however, were not delivered in a gender-sensitive way. In 2004, the forest administration therefore asked the authors to look at the given answers again with respect to gender aspects. According to the reanalysis of the data, the minimum percentage of female forest owners registered at about 14 percent, or 83000 hectares. However, it has been estimated that the actual figure ranges somewhere between 14 and 20 percent.

The new analysis showed that women tend to have smaller forest properties (less than 20 hectares), that they more often lease their agricultural properties, and that they seem to have a lower interest in organizing themselves in forest owners' associations. Furthermore, they seek more advice from the state forest service and visit their properties less often than men (who tend to think they have better knowledge of forestry). Moreover, the review also showed that female forest owners have a lower interest in hunting, have less formal qualifications in forestry and characterized, more than men, as "ecologically motivated".

\subsubsection{Conclusions}

However preliminary these results are they do show a slight difference in structure, perception and motivation of male and female forest owners in Nordrhein-Westfalen. Further research in this field is therefore needed. 


\subsection{NORWAY}

By Berit Sanness

\subsubsection{Introduction}

In Norway, families primarily own 80 percent of forest area, municipalities, common forests, companies and other entities own 10 percent, and the state owns the remaining 10 percent.

According to Norwegian statistics (2004), of the 118500 forest owners in Norway 22 percent of them are women. ${ }^{9}$ However, the actual number of forest owners is not actually reflected in the number of people that were registered as forest owners because most forest owners are married and about 80 percent of married couples own the forests holdings together (Strupstad, 1991).

There are two national forest owners' organizations in Norway: The Norwegian Forest Owners' Federation and the Norwegian Forestry Association. Approximately 80 percent of the volume of annual felling comes from the 43500 members of the Norwegian Forest Owners' Federation, while some 10 percent of the volume of the annual felling comes from the 240 members of the Norwegian Forestry Association. Both organizations supported the launching of Women in Forestry, contributed to working groups during last part of 1980s and early 1990s and are still members of the organization. This chapter concentrates on the gender structure in the Norwegian Forest Owners' Federation.

\subsubsection{Gender structure in the Norwegian Forestry Association}

The gender situation within the Norwegian Forestry Association has been nearly the same for the past 20 years. Women members account for 10 percent of total forest holdings, but in 3 percent of the cases both the man and the woman are registered as owners. At the general assembly, women make up about 15 percent of the participants. Since 1985, a woman has been on the board of directors, with a woman chairperson presently guiding the board. At the district level, one of the 20 elected board members is a woman. There are, however, no representatives of the employees on the board of directors. The managing director of the organization has always been a male. Of the 15 employees of the association, five are women, and of the three people who report to the managing director one is a woman (Olga Nyborg, the Norwegian Forestry Association, personal information, 15 March 2006).

${ }^{9}$ Only forests holdings covering more than 2.5 hectares are included in the statistics. Source: Norwegian Statistics, 2004. 


\subsubsection{Gender structure in the Norwegian Forest Owners' Federation}

\subsubsection{Introduction}

The Norwegian Forest Owners' Federation is the federal umbrella of the organization and is composed of eight district forest owners' associations and about 360 local forest owners' associations (December 2005). Recently, a restructuring has taken place, particularly at the district level. In 1986, district associations numbered 19, while local associations amounted to 460. At present, the size of the district associations differs considerably. Viken Skog BA is the largest association and handles about one-third of the timber trade, while the smallest one executes less than 1 percent.

\subsubsection{Gender balance on the agenda}

Gender status twenty years ago

In 1986, the Norwegian Forest Owners' Federation was entirely male dominated. Although there were a few women board members at the municipality level, none presided at the national level and district level. Similarly, positions such as forest officers or senior professional-level professions were all held by men. Among the employees, women mainly held secretarial posts except for a woman economist who managed one of the smaller district associations. Therefore, the 1986-established organization Women in Forestry (see Chapter 4.4) was highly welcomed by the Norwegian Forest Owners' Federation and its executive Egil Molteberg. This support had a significant impact on the new organizations' general acceptance and position within the forestry sector, and for several years gender balance was put on the agenda in various ways.

On behalf of the Federation, between 1990 and 1992 a project was initiated in one of the forest owners' district organizations (Sør-Trøndelag) in order to test ways for increasing female forest owners' involvement in forestry; as a result, a number of actions were implemented. The Federation also supported a general campaign created by the Federation of Norwegian Agricultural Co-operatives for increasing the level of women within the agriculture and forestry sectors.

Today some of the actions that have been implemented to meet female forest owners' needs are also likely to be relevant for the new generation of men that have become forest owners. More and more forest owners receive their education and income from other sectors due to reductions in timber prices and the economic conditions within the forestry sector.

\section{Women's visibility in forest magazines}

Brandth, Follo and Haugen (2002) studied the visibility of women in the magazine of the Norwegian 
Forest Owners” Federation “Skogeieren” (The Forest Owner) by comparing volumes from 1976, 1986 and 1996. While women were in the shadows in the 1976 volume, they appeared more fully in 1986, partly due to political focus and partly due to the establishment of Women in Forestry. Women were now presented as "something" in themselves, and not only as the spouses of male foresters. The most significant changes began to appear with the 1996 volume, as women were, in addition to continuing the "women as a curiosity", now being shown as experts.

A study of the photographs used as general illustrations or presenting people interviewed in the magazine, demonstrates that the share of women pictured has been kept at a rather low level. In the 1986 volume, the share of women in the magazine amounted to 8 percent, while 6 percent applied to both men and women. Between 1997 and 2005, women had a 12 percent share on average, while the share of both genders was 10 percent on average. These low figures unfortunately confirm that gender balance in the magazine's editorial policy has not been implemented.

\section{Changing by-laws to improve gender balance}

During the last ten years, the federal level has not done much to improve gender balance within the forestry sector or within the organization. However, there are two important exceptions. The Federation recently:

- recommended that each forest holding should have two votes to facilitate the improvement of gender balance in the organization; and

- stated that both genders were to be represented on the board of directors at the district level with at least two members.

\section{Two votes per forest holding}

In 1992, half of the district associations had some local associations that had positive gender actions included in their by-laws (the Norwegian Forest Owners' Federation, 1992). In 2005, all district associations, except for Glommen Skog BA, approved by-laws that in different ways give possibilities for couples owning the forest holding together to have one vote each in the general assemblies at the local level (Gudbrand Kvaal, the Norwegian Forest Owners' Federation, personal information, 22 March 2006).

\section{Quotas on the board of directors}

As a consequence of the government's focus on gender balance within the board of directors, the Federation of Norwegian Agricultural Co-operatives took an initiative in autumn 2003 that aimed to achieve 
gender balance on the boards in the agriculture and forestry owners' cooperatives on a voluntary basis by 2009 . The Norwegian Forest Owners' Federation supported the ambitions and recommended actions to be taken by the district associations.

In 2005, five of eight district associations (Viken Skog BA, Mjøsen Skog BA, Glommen Skog BA, Havass Skog BA and AT Skog BA) included a clause demanding that both sexes be represented, with at least two people on the board of directors. Two district associations demanded that both sexes be represented on the board of directors (e.g. Allskog BA), while the last association had no gender demand at all. There are no demands concerning gender balance when it comes to employees' representation on the board of directors (Ibid).

The Federation also recommended new by-laws at the local level, including a demand that both sexes be represented on the local board of directors (the Norwegian Forest Owners' Federation, 2005). The implementation of the recommendations varies, but in general, a demand or a recommendation of having two women on the board of directors at the local level will probably be implemented in the majority of the local forest owners' associations during spring 2006.

\subsubsection{Gender structure on the board of directors}

\section{National level}

Since 1989, a woman has been a member on the federal board of directors, which represents a a share of 14 percent. In the period between 2002 and 2005, its chairperson was a woman. In June 2006, the by-laws are expected to be changed, and will demand that the board of directors consist of chairpersons of the district associations. This action will limit the possibilities for achieving gender balance for years, as so far no woman has chaired any of the district associations.

\section{District associations}

The first women board members of two district forest owners' associations were elected in 1987. Since then, the share of women has increased. In 2005, all of the eight district associations had at least one female forest owner as a board member (see Table 39). Since spring 2006, the share of women is 30 percent, with a goal of attaining 40 percent share by 2009 .

Table 39: Share of women on the board of directors, district associations, 1986-2005

\begin{tabular}{lccccc}
\hline Election process & $\mathbf{2 0 0 5}$ & $\mathbf{2 0 0 1}$ & $\mathbf{1 9 9 6}$ & $\mathbf{1 9 9 1}$ & $\mathbf{1 9 8 6}$ \\
\hline Elected by forest owners & $25 \%$ & $10 \%$ & $7 \%$ & $4 \%$ & $0 \%$ \\
\hline Elected by employees & $0 \%$ & $22 \%$ & $0 \%$ & $10 \%$ & - \\
\hline
\end{tabular}

Source: The Norwegian Forest Owners' Federation; data from 1986, 1991, 1996, 2001, 2005. 


\section{Local associations}

The number of local forest owners' associations decreased from 462 in 1986 to 357 in 2005. The statistics concerning gender distribution is insufficient. In addition, a number of organizations have merged making it difficult to locate proper documentation at the local level; however, the annual reports and other documents from forest owners' district associations from the past 20 years provide adequate information for analysis (Table 40).

Table 40: Share of women as board members of local forest owners' associations, 1986-2005

\begin{tabular}{lccccc}
\hline Forest owners' association & $\mathbf{2 0 0 5}$ & $\mathbf{2 0 0 1}$ & $\mathbf{1 9 9 6}$ & $\mathbf{1 9 9 1}$ & $\mathbf{1 9 8 6}$ \\
\hline Viken Skog BA* & $17 \%$ & $8 \%$ & $7 \%$ & $5 \%$ & $1 \%$ \\
\hline Glommen Skog BA & $17 \%$ & $16 \%$ & $11 \%$ & $7 \%$ & $4 \%$ \\
\hline
\end{tabular}

*Includes associations that merged before 2000 .

In spring 2006, the share of female board members at local level Viken Skog BA is estimated to be 20 percent (Stig O. Sorthe, personal information, 6 April 2006). Data from Mjøsen Skog BA show that while the share of women among local board members was 3 percent in 2000, it increased to 10 percent in 2005 (Dahl, 2006). Allskog BA has also shown an increased share of women board members, from 5 percent in 2002 to 15 percent in 2006 (Sjåvik, 2006).

\subsubsection{Gender structure among employees}

\section{National level}

The number of employees in the Norwegian Forest Owners' Federation was about the same in June 2005 as in June 1986, but in the 20-year period in between the Federation had more than 30 percent more employees. In the 1990s, one female forestry graduate became member of the leader team. At present, only three of the 19 employees are forestry graduates from the University of Agriculture, but all of them are men. Recently, however, two women were hired to be communicators at the chief level.

\section{District associations}

Since 1991, the number of people as members of the leader team or senior-level employees decreased by 50 percent, while the number of forestry advisers, who are seen to be key people in the association as they communicate with individual forest owners, reduced by one-third (see Table 41). 
Table 41: The share of women employees at district level in forest owners' organizations (1986-2005)

\begin{tabular}{|c|c|c|c|c|c|}
\hline Share of women & $2005 *$ & $2001 *$ & 1996* & 1991* & 1986* \\
\hline $\begin{array}{l}\text { Share of women employees, } \\
\text { chief level** }\end{array}$ & $4 \%$ & $13 \%$ & $7 \%$ & $5 \%$ & $6 \%$ \\
\hline Share of women forestry advisers & $4 \%$ & $2 \%$ & $3 \%$ & $1 \%$ & $0 \%$ \\
\hline
\end{tabular}

*June. $\quad * *$ Includes senior level.

Source: The Norwegian Forest Owners' Federation; data from 1986, 1991, 1996, 2001, 2005.

Contrary to recent improvements concerning gender balance among board members, the gender balance has had a backlash among employees at the chief and senior levels, and even among forestry advisers, as the percentage is still low, at 4 percent.

\subsubsection{Gender actions at the district level}

\section{Allskog BA}

A few years ago six forest owners' district associations merged to become Allskog BA. In 2005, it covered 104 local forest owners' associations, had 9250 members, and a timber trade of almost $800000 \mathrm{~m}^{3}$ (the Norwegian Forest Owners' Federation, 2006). At present, 25 percent of the owners' board members of the district associations are women while the share of female chairpersons of the local associations is 5 percent. Just this spring (2006), one female employee was elected as board member at the district level.

In 2003, the gender process named "Kvintetten" was launched with the objective of increasing the share of women within the organization. This meant increased share of female members, increased share of female board members and more active female members. Based on the strategic plan and decided by the board of directors of Allskog BA, the "Kvintetten" became the meeting point of the gender work of Allskog and became closely aligned with Women in Forestry. The initiative arranged a motivational seminar with 70 female forest owners in 2004 and three regional meetings on "women as key consumers" in 2005. The local election committees have been targeted and several forestry meetings regarding the gender issue have been held for men as well as women. The member registry of Allskog BA has been improved and now includes both names when couples own a forest holding together. Other initiatives include a separate column for Women in Forestry in the association's magazine (Sjåvik, 2006), and a successful mentor programme that has been tested in various areas by the Norwegian Centre for Rural Research. In spring 2006, the chairperson of "Kvintetten”, Mr Kåre Sjåvik, was honoured with the Gender Prize by the Federation of Norwegian Agricultural Co-operatives for his enthusiastic leadership of Allskog BA's gender process. 


\section{Viken Skog BA}

Because of a merger of three forest owners' district associations in the late 1990s, Viken Skog BA has become the largest district association within the Norwegian Forest Owners' Federation. In 2005, the organization covered 90 local forest owners' associations, had almost 13800 members, and a timber trade totalling $2057000 \mathrm{~m}^{3}$ (the Norwegian Forest Owners' Federation, 2006). In 2006, 40 percent of the owners' board members of the district association are women, 20 percent of board members at the local level are women, while the share of women chairpersons of the local associations is 6 percent..

In 2004, the board of directors implemented a programme (2005-2006) that aimed to increase the percentage of women onto board of directors, committees and governance to 40 percent by 2009. The chairman of Viken Skog BA is also the chairman of the project board. Female board members of Viken followed the "Female Future" programme for female board members of stock exchange companies (www.nho. no/article4628.html). As a follow up, a motivation seminar with keynote speakers was held in spring 2005 with 150 participants, followed by nine regional competence activities for 170 female forest owners. More of these competence courses will be offered in 2006, in addition to the events promoting wood. The member registry of Viken Skog BA has been extended to include both names when couples own a forest holding together. The election committees have been targeted and will be followed closely in 2006. Furthermore, the association's magazine includes information about gender actions. All nine regions have their own female contact persons, and even in local associations, female contact persons will be identified.

\section{Mjøsen Skog BA}

In 2005, the organization Mjøsen Skog BA covered 29 local forest owners' associations, had 4210 members, and a timber trade of $813000 \mathrm{~m}^{3}$ (Ibid). Some 20 percent of the members were women, with more than half registered as sole owners. At the general assemblies of the local associations, the share of women has differed between 0 and 5 percent for several years (Dahl, 2006). In 2006, 33 percent of the owners' board members at the district level are women, while the share of female chairpersons of the local associations has increased to 10 percent.

Mjøsen Skog BA has improved its gender balance step by step. In 1991, the local associations were asked to involve more women into the organization and in 1992 the by-laws were changed to allow two votes per owner couple (when joint ownership) when both parties were present at the general assemblies. One year later, Mjøsen offered to register both of them in the membership registry. In 1994, improved gender structure was highlighted as an accomplishment, and it helped to advance women's representation. For instance, in 2000 
the by-laws changed and required that at least one member of the local boards be a woman, while in 2004 a new action plan included gender structure. Furthermore, last year a motivation seminar was organized and the association's magazine opened a special column for women's views.

\section{Glommen Skog BA}

In 2002, Glommen Skog BA merged with one smaller district association. In 2005, the organization covered 20 local forest owners' associations, had almost 2900 members, and a timber trade amounting to $1300000 \mathrm{~m}^{3}$ (the Norwegian Forest Owners' Federation, 2006). About 21 percent of the members are women, either owning the forests alone or together with other individuals. In 2006, 33 percent of the owners' board members of the district association are women, while the share of female chairpersons of the local associations was 14 percent in 2005. This spring, one female employee was elected as board member at the district level. Glommen Skog BA had been a pioneer concerning gender structure, as the first woman entered the board in 1987. However, for many years little else was done. In 2004, however, Glommen placed gender structure on the agenda again with the aim of increasing the share of women on boards, committees and the governance of the association. To achieve this goal, the organization initiated a project, with a trainee committed to the issue, and a motivation seminar for about 50 female members was held in spring 2005 (Haugen, 2005). Today, the by-laws include a clause demanding that both sexes be represented, with at least two people on the board of directors of the district association. Morever, the association's magazine now includes information about gender actions.

\subsection{GENDER STRUCTURES IN FINNISH FAMILY FORESTRY}

By Lea Jylha, MTK Central Union of Agricultural Producers and Forest Owners (Finland)

\subsubsection{The Finnish ownership structure}

Private individuals and families own 60 percent of the Finnish forest area: 920000 people own 444 000 forest holdings. Women are owners and responsible for the management of one-fourth of holdings; however, this figure underestimates the share of women among forest owners. In general, men are responsible for the management of forest holdings jointly owned by the spouses, by heirs or other types of collective ownership. Men are then the principal owners. Thus, the actual share of women as forest owners is about 40 percent. 


\subsubsection{The MTK}

The Central Union of Agricultural Producers and Forest Owners (MTK) is the national interest organization for farmers, forest owners and rural entrepreneurs. MTK has about 170000 members in local agricultural producers' unions and forest owners' unions. MTK's Forestry Council is the national policy organization of family forest owners, and its members are 13 regional Forest Owners' Unions, which guide and develop the operations of local Forest Management Associations (FMAs). The 154 FMAs are governed and financed by forest owners, and provide practical advice and services to forest owners. Altogether, the FMAs have 320000 forest holdings and 633000 owners as members.

\subsubsection{Gender structure at the national level}

The MTK Forestry Board at the national level has nine members - all men, including the chairperson. At the general assembly, 45 delegates attend, and the share of women participating at the assembly is 4 percent. At the national office (headquarters) of MTK, there are 70 employees, with a male as managing director. The share of women at this office is almost 49 percent. Eight people among the employees are educated as foresters. The forestry division at MTK, headed by a male forestry director, has nine employees of which three are women. Among the forestry graduates, the share of women graduates is almost 38 percent.

\subsubsection{The Regional level}

Each of the 13 regional Forest Owners' Unions has its own board of directors elected by the owners. Altogether 128 people are regional board members, with the share of women among them at only 3 percent. All chairpersons of the regional board of the directors are men.

\subsubsection{MTK's equality programme}

MTK adopted its first equality programme in spring 2006. One of its goals is to increase the share of women to one-third in MTK's decision-making bodies. MTK's Forestry Council annually monitors the development of women's share. More information is provided about equality at all organizational levels, and women are encouraged to participate in events organized by MTK and to accept posts as elected representatives, starting from the local association level.

The network of female forest owners that has been operating for some years now will now be extended and its activities will be intensified. The aim is to facilitate female participation and encourage women to take a more active role both within the organization as well as in the management of their own forests. 


\subsection{GENDER STRUCTURES IN BALTIC FAMILY FORESTRY}

By Diana Mizaraite (Lithuania) and Merete Furuberg

\subsubsection{General aspects of the forestry sector in the Baltic States}

\section{Ownership structure}

The structure of forest ownership has changed in the Baltic countries owing to an ongoing land-reform process ever since Estonia, Latvia and Lithuania regained independence. Privately owned forests amount to 36 percent in Estonia, 45.1 percent in Latvia and 31.4 percent in Lithuania. The forest area under restitution comprises 25 percent of the total forest area in Estonia and 18.9 percent in Lithuania. State-owned forests comprise 39 percent in Estonia, 51.2 percent in Latvia and 49.7 percent in Lithuania.

\section{Small-sized private forest holdings}

Small-sized private forest holdings represent the Baltic States, with an average holding size of 10.5 hectares in Estonia, 7.5 hectares in Latvia and 4.5 hectares in Lithuania; the latter, incidentally, has about 44 percent of private forest owners residing in towns.

\section{Gender structure among the owners}

The majority of forest owners are 60 years or older, and more than half of private forest owners are women.

\section{Annual felling}

The felling volume of Lithuania's private forest was more than 1.4 million cubic metres in 2001 and 2 million cubic metres in 2002 . This amounts to 40 percent of total roundwood supply in Lithuania. In Latvia, the volume felled in non-state forests was 6.7 million cubic metres in 2001 and 7.4 million cubic metres in 2002. In Estonia, felling in private forests increased from 0.6 million cubic metres in 1995 to 8.3 million cubic metres in 2001.

\section{Forestry authorities}

Since regaining independence, the structure of forestry authorities has changed in all three countries. The Department of Rural Development at the Ministry of Agriculture has been the lead forest agency of the government and is primarily responsible for private forestry in Estonia.

In Latvia, the main institution responsible for the forest sector is the Ministry of Agriculture. Its forest section of the Ministry of Agriculture comprises two departments: the Forest Policy Department and Forest Resources Department. 
Since Lithuania has regained its independence, its authority structure has changed a number of times. The Department of Forests at the Ministry of Environment has been the lead forest agency of the government and is primarily responsible for forest policy and legislation concerning the Lithuanian forestry sector since 2002. This department includes the Private Forestry Division.

\section{Forest owners' organizations}

Private forest owners are not yet a fully organized group in the Baltic States. However, organizations of private forest owners have been established in all three countries: the Estonian Private Forest Owners' Union, the Forest Owners Association of Latvia and the Forest Owners’ Association of Lithuania.

The Forest Owners Association of Lithuania (FOAL) was established in 1993, and represents and unites private forest owners. Currently, it operates on the basis of 39 local units, and regional units of FOAL will be established in all regions of Lithuania. FOAL likewise supports the establishment of a network of forest owner cooperatives that are already now supplying over 10 percent of roundwood from private forests.

\subsubsection{Private management problems and the needs of the private forest owners}

\section{Restitution challenges}

The new modes of ownership (private forests) have brought new tasks for both private forest owners and forest authorities/administrations responsible for the forest policy and its implementation. More often than not the forest authority makes decisions related to private forest owners' training and advisory system, organizational structures of private forests owners, wood trading, private forest management despite the needs of private forest owners and the new political culture in forestry.

\section{The forest owners' aims and challenges}

It is necessary to carry out detailed studies for defining the aims, needs and problems of private forest owners. In Lithuania, the first survey of private forest owners' aims, needs and problems was carried out in 1999 (Mizaraite, 2001). The survey's main objective was to discover the goals and problems of private forest management as well as the needs of private forest owners. Of the 267 respondents who were interviewed, 65.9 percent were male and 34.1 percent female. The average age of respondents was 53 years, the average size of forest properties was 5.8 hectares, and the average distance from the forest holding's location to the owners' residence was about 30.6 kilometres.

The respondents were assessed by property acquisition as follows: forest property was restituted -65.5 
percent; the forest property was purchased - 19.1 percent; the forest property was given as compensation for other property - 10.9 percent; other -9.8 percent (26 respondents).

According to the survey results, the main forest management problems are: the forest property is too small to achieve efficiency (73.8 percent); strict legal regulations related forest management (61.0 percent); and lack of money for silviculture activities. During the survey process, the respondents stated a number of forest property management objectives. The most important objective for respondents was to harvest timber for their own purposes (77.5 percent), and to put the timber on the market and seeking a stable level of income (63.3 percent). The objectives of aesthetic value (beauty, tourism, recreation, etc.) amounted to 61.4 percent and protection of nature was also a big priority for the respondents, as it stood at 45.3 percent.

The most necessary services for private forest owners are forest services for protection against fire, insects, etc. (39.7 percent), advisory services (60.3 percent), and preparation of special material and literature (52.8 percent). Of the respondents, 45 percent wished to be members of cooperatives with the main activities targeted at forest protection and commercial services.

\section{The forest owners need for information and extension}

A case study for examining the information and training needs of private forest owners in Estonia was carried out in 2001 (Pellervo Economic Research Institute, 2003). A survey targeting forest owners to determine their needs, as a group and within various different owner groups, was sent to 844 forest owners. Of the 844 questionnaires, 584 of them were returned, about 76 percent of respondents were male and 24 percent female.

The recent study indicates that 61 percent of forest owners are male, compared with 73 percent in mid1990 (Karppinen 1996), and 39 percent female. Therefore, it seems to show that the share of female forest owners has increased in Estonia during the latter part of the 1990s.

The respondents were asked to evaluate how problematic they consider various issues regarding private forestry in Estonia. Respondents indicated five severe problems in Estonian private forestry: illegal logging, scarce investment capital of forest owners, taxation, a lack of tradition in private forestry, and the fact that many forest owners live apart from their forest estates (Ibid). The problems in private forestry are reflected in forest owners' information needs.

According to the survey results, information is mostly needed on legal and economic issues, but also on forest diseases and pest control (Ibid). In addition, Estonian private forest owners have strong information needs about forest management, environmental matters and roundwood markets. The similar problems that 
private forest sectors have in Baltic countries are not surprising. Because the Baltic countries transferred to a market economy at the beginning of the 1990s, forest legislation and traditions of forest estate management are young; these areas are still developing and implementation and control of legal acts will take some time.

\subsubsection{Conclusions}

The structure of forest ownership has changed in the Baltic States owing to an ongoing land reform process ever since these countries regained independence. Small-scale private forestry is increasing in the Baltic States in particular. During recent years, roundwood supplies from private forests have been consistently increasing in all Baltic States.

The private forest owner's association and cooperation process is developing. The main problems of the private forestry sector are small-sized private forest properties, weak cooperation of forest owners, lack of forest management knowledge, and insufficient support from the state. The integration of the Baltic States into the European Union should have a positive influence and resolve some of these problems.

\subsection{SUMMARY AND CONCLUSIONS}

In Europe, about 55 percent of forest area is privately owned; in North America, the share is 36 percent. Forests owned by individuals are called "family forests". Approximately 60 percent of the forests within the European Union are "family forests", owned by about 16 million families. In the United States, the number of family-owned forest holdings is close to 10 million, while in Canada it numbers about 0.5 million.

Determining gender structure in family forestry is difficult because the forestry sector lacks overall data, both in Europe and in North America. To learn more about the structures, questionnaires were distributed to forest owners' organizations, but only a number of them were returned. The Team understands the lack of response as a result of missing data on the gender structure within the organizations.

The Team of Specialists on Gender and Forestry gathered information from a number of countries. Although the focus of the contributions differs from case to case, the situation in forestry clearly demonstrates the need for gender-divided documentation and statistics concerning forest ownership, both countrywide and within the forest owners' organizations.

The Baltic States represent the highest share of women as forest owners, as more than 50 percent of them are women. In the Nordic countries, Sweden has the highest share of women forest holders, almost 40 percent; Finland is also estimated to have the same share if forest holdings jointly owned by spouses, or other individuals, are taken into consideration. However, far less ownership is registered for women. 
The case studies in this chapter demonstrate that even with a rather high share of forest ownership (e.g. in Sweden), women have a rather low impact on forest management. Several case studies show that gender balance is missing concerning the board of directors and the senior levels within forest owners' organizations. Correcting this imbalance is a major challenge for the forestry sector.

One of the business reasons for improving gender balance within the forestry sector is women's position as key consumers. Improved gender balance within family forestry could improve communication, as female forest owners are also female consumers and part of other women's social networks.

The Swedish case study shows that men and women place different values on goods from the forests, while a preliminary study from Germany found slightly differences in structure, perception and motivation of male and female forest owners in Nordrhein-Westfalen. These examples illustrate that gender balance among forest owners might have an impact on the management of forest resources. On a general basis, it should be pointed out that urbanization among forest owners and reduced economic outcome from the forests might reduce the differences between the sexes concerning forestry values and forestry needs among the next generation of forest owners.

The Team of Specialists on Gender and Forestry finds it interesting that after having had gender balance on the agenda for 20 years, Norway has finally achieved substantial progress. A threat of new laws and regulations if the forest owners' associations do not achieve the requirement of 40 percent women on the board of directors by 2009, has forced innovation and the associations have started to intensify their actions for achieving the goal.

In Finland, the share of female forestry graduates is almost 40 percent in the forest owners' organization, but women board members in these forest owners' organizations are nearly absent. In spring 2006, MTK adopted its first equality programme, with one of its goals of having one-third representation of women in MTK's decision-making bodies.

The chapter closes by highlighting some of the forestry challenges for countries in transition, exemplified with the situation in the Baltic States. The reprivatization of forestland has brought challenges to the families that once again have become the legal owners of their forest holdings as well as to forest authorities. More than half of forest owners in the Baltic States are women. As the age of the owners are 60 years old on average, it is likely that many female owners are widows. 


\section{GENDER AND PERCEPTIONS OF FOREST AND FORESTRY}

\subsection{PERCEPTIONS OF FORESTS AND FORESTRY - WHAT PEOPLE THINK ABOUT FORESTS AND FORESTRY}

Forests play a vital role in the everyday life of millions of people all over the world. It has to be stated that over the last few decades crucial changes have taken place in the views and demands on forests by society. Societal changes caused by globalization, urbanization, increasing time budgets for recreation, tourism and sports, and environmental awareness and access to multiple sources of information all have had severe impacts on people's perceptions and attitudes towards forests and forestry.

One of the challenging questions is whether men and women worldwide need, use and look upon forests and their management in different ways. While publications on gender aspects and forests/forestry within the southern hemisphere and developing countries are well on their way (Lyren, 2003; WRM, 2004, 2005; Griffen, 2003), western societies still seem to be reluctant to tackle the gendered dimension of the "forest world". What has been said in the previous chapters about the lack of gendered data and research on forest organizations and forest ownership might as well be true when we talk about forests, forestry and their perceptions by society: society meaning women and men, girls and boys, young and elderly people, migrants, and people with certain disabilities, among others.

Focusing on Europe and North America it has to be recognized - in general - that the vast majority of the population today lives in urban areas and that the perception of forests as well as forestry and forest management is strongly influenced by urban thinking and the urban relationship with nature. The seminar on "Women in Forestry" in 2001, in Portugal, concluded: "In Europe and North America where political decisions about forestry are increasingly determined by urban populations with little factual knowledge of forestry, the sector is still beset by a negative image as an extractive industry. Women as members of the public could be strong allies for the forestry sector if it effectively communicated its role as a steward of forests managed for a wide range of values including, but not limited to, timber. Public participation is a promising tool for two-way communication which women should be encouraged to use" (seminar proceedings, page 8, conclusion 34).

In 2003, the MCPFE published a Review of Representative Public Opinion Surveys in Europe called "Europeans and Their Forests". This report is a first attempt to collect and present results of representative public opinion surveys undertaken in Europe since 1990. The purpose of this report is to contribute to a better 
understanding of the views of society on forests, forest management and benefits. Looking, for example, at the answers to the question "What do forests mean to Europeans" one of the most striking results of the survey is that forests are first and foremost perceived through impressions and feelings. Perceptions are dominated by "fresh air", "green”, quietness", "happiness", "trees", and "wood”, or the recreational functions of forests. The forest is a symbol of nature. But negative aspects regarding forests also prevail. They deal with "threat", "darkness", "danger" or "forest dieback" on international and national scales. People are aware of the multiple roles of forests, and preservation and protection are the most important roles of forests. People often are unaware about questions of forest ownership.

Judging forest management, the confidence in sustainable forest management (SFM) varies considerably. Europeans seem to be divided over whether or not sustainable forest management is applied and the report notes that women and young people (15-to-25-year olds) are especially more sceptical. These results reveal that information provided to the public about forestry measures has to take gender and age differences more into consideration.

The Team of Specialists on Gender and Forestry is aware of conclusions, findings and discussions from international seminars, processes and networks on the relationship between society and forestry. The development of strategies and tools to communicate about the forests, forest management and land ownership is supported. Although research institutions and administrative bodies are strongly advised to take the gender dimension into consideration not many case studies, research results or practical approaches to include the gender dimension could be found while drafting this report. However, from three separate studies in Catalunya, Spain, evidence on the influence of gender formation of forestry-related values are presented. The authors, Ferrera, Reira and Mogas (Forestry, vol. 78, no. 3, 2005) report statistically significant difference in people's preferences, especially between older women and older men and older and younger women. Although there was no overall difference in preference attributable to gender, there were significant differences related to age and income, in combination with gender. Further, the Forest Commuicators Network on several occasions has put emphasis on the fact that special attention should be drawn to women and young people. The following case studies are examples of differences in perceptions towards forests. 


\subsection{THE PUBLIC'S PERCEPTION OF AND RELATION TO THE FOREST OR HOW SWEDISH MEN AND WOMEN VIEW THE FOREST}

\section{By Gunilla Törnquist-Hedström}

When the Swedish Forestry Organization celebrated its 100-year anniversary in 2005, it presented the results of a survey of the public's perception of and relation to the forest.

The questions regarding the public's perception of and relation to the forest were part of the survey "Your Country, Your Life", which is conducted at regular intervals by the Research Group for Society and Information Studies. Questionnaires with these questions were mailed to randomly selected people in the age range of 16 to 79 years. More than 900 persons answered the questions during the period January to March 2005.

After the results came back, the replies were not divided into the respondent categories of men and women. Since the material has been made available by courtesy of the Forest Board, the Team of Specialists has reviewed the replies to establish how men and women reply. In all, 989 persons replied to the questionnaires; however, the number of non-respondents is not evident from the material made available to us. This is a reservation we have to make as to how correct and scientific the material is. It is known, however, that the proportion of men and women living in urban and rural areas largely corresponds to official Swedish statistics.

\section{More men than women live in rural areas}

Of the 989 respondents who stated their gender, 47 percent were men and 53 percent women, of which 23 percent of the women and 26 percent of the men live in large urban areas, while more women (59.6 percent) than men (51.4 percent) live in other urban areas. The remaining respondents live in rural areas, and here there are more men (21.5 percent) than women (16 percent). Respondents who live in a forest or a forest area is lower for women than men, 23.1 percent and 30 percent, respectively; and 51.6 percent of the men and 49.1 percent of the women said that they had grown up in a rural environment. Only 1.1 percent of the women but 13 percent of the men liked to hunt.

\section{How to use the forests}

The respondents were asked to rate the questions by indicating a 1 (not at all) to a 7 (to a very high degree) with regard to the different uses of the forest. The different uses were: demand for forest raw material, outdoor life needs, consideration of biological multitude and environment, safeguarding cultural environments, reindeer breeding interests, hunting and fishing interests, and the importance to public health. 
The replies to the question about the forest's useful things - to what degree do you think that different considerations and interests should influence the Swedish use of forest - there was some difference between the opinions of men and those of women. However, the question on the demand for using forest raw material, i.e. timber production, men were more receptive to production than women were.

As for outdoor life needs, the situation is reversed - 34 percent of the women stated that it was important (to a high degree) to consider outdoor life needs - whereas only 24 percent of the men believed so. On the question about biological multitude, there was an even greater difference as two-thirds of the women stated that it was important (to a high degree) to consider biological multitude, whereas only a third (38 percent) of the men thought so.

The need to safeguard cultural environments is felt to be twice as important to women (46 percent) as to men (23 percent). Furthermore, more women (22.6 percent) than men (13 percent) think reindeer breeding is important.

Women and men have similar opinions regarding the impact of hunting and fishing interests on the use of the forest, as 57 percent of the women and 50 percent of the men think that hunting and fishing is important. Despite the fact that there was a great difference between male and female respondents regarding the practicing of hunting and fishing, 5 of the female respondents were hunters against 52 of the men. More men liked to fish on their spare time (137) than women (50).

There is great difference between the genders with regard to how important the forest was to public health: women value the forest much more for public health than men do because 60 percent of them replied that the forest was important (to a high degree), whereas only 45 percent of males answered so. On the other hand, the question for enhancing quality of life by going to the forest and experiencing nature is more equally shared, 84 percent of the women and 78 percent of the men answered positively. However, on a daily basis more women than men take advantage of park-like forests or the forests that are near urban areas. The pattern differs, however, as to how frequently they visit the different types of forests but, overall, women seem to venture more often to the forests near urban areas. There are two distinct groups of forest users: those who are out daily, perhaps dog owners, and those who seldom visit the forest.

A small number of men and women work in the forest. A great number of men, however, use the forest for such activities as hunting or fishing - 11 percent of them stated that they hunted each month, against only 1 percent for women.

More women than men take walks daily: 15 percent of the women take walks each day, whereas only 8 percent of men do. The same applies to exercise, jogging, and skiing, for example. Here, a division might have been interesting. 
There is also a noticeable difference between the genders with regard to berry and mushroom picking: 28.7 percent of the women claim to pick berries or mushrooms once every six months, against a fifth of the men (20 percent); and 37 percent of women picked berries or mushrooms once a year while 32 percent of the men stated they did. Consequently, more than half of the women pick berries or mushrooms whereas a somewhat lower proportion of men do. It would be interesting to know whether those who claim to pick mushrooms and berries live close to the forest or whether they grew up in a rural environment, or whether some other factor influenced them.

\title{
The public spends less time in the forest than before
}

Respondents, both men and women, seldom spend time in forests and nature, according to 34 percent of the men and 31 percent of the women. Less than 30 percent of the women and men use the forest for recreation. As for time spent using the forest, more people stated that they spent less time in forests and nature compared with five years ago. It would have been interesting to learn who spent less time in the forest and whether it was related to the place where they live, age range, and other. It would also have been interesting to have had access to more background variables to find out whether there are any differences between different groups of women, for example older/younger, where they live and where they were raised.

The questionnaires revealed a distinct pattern - women would like the forest to be used more for "soft" purposes rather than for exploitative uses and their behaviour also indicates that they use park-like areas and forests near urban areas more than men do.

\subsection{INNOVATION AND FORESTRY: ATTRACTING VISITORS AND CHANGING PERCEPTIONS}

\author{
By Patricia Tomlin
}

\section{The case-study objective}

The aim of this case study was to identify a community group or business that was attracting local people to their forests and helping to change current perceptions on forestry in innovative ways. This case highlights an example of good practice in the United Kingdom.

\section{The methods applied}

The case study was conducted through an informal interview with the Projects Officer, Nicola Williamson, within the Borders Forest Trust. Additional information was sought through secondary research using publications and the Internet. 


\section{Introduction}

Borders Forest Trust (BFT) was established in 1996 principally through an amalgamation of three different local projects in the Borders (southern Scotland): Borders Community Woodland, Peebles Environmental Concern and No Butts. Borders Community Woodland's aim was to give back to forests and the result was the first community woodland, which was bought through this initiative. Peebles Environmental Concern's objective was to help restore native woodlands to the Borders and encourage woodland wildlife to prosper. Finally, No Butts was established to encourage the local use of hardwood timber. BFT brought these organizations together as an umbrella initiative with a charity status and now owns 2000 hectares of land and has an annual turnover of $f_{400} 000$ per annum.

The BFT has a very inclusive and generic focus on educating people about forestry and how woodland can be used. Their work will therefore help change perceptions about forestry and the timber industry. Through working with children in interactive projects they are creating positive perceptions about forestry, which will help to change the idea that forestry is a "man's world". In the local adult community, BFT is witnessing an increased participation in forestry of women with a third of the BFT board of trustees represented by women.

\subsubsection{Borders Forest Trust Projects:}

\section{Working with the local community}

The overall aim of the charity is to encourage people to make use of and manage forests and to try increasing the number of local people who use home produced timber. This initiative has helped 20 different local community woodland groups to buy and manage local woodlands with many of these groups becoming autonomous, allowing staff at BFT to focus on new projects. They are switching the use of land from commercial conifer crops to local woodland species in a hope to emulate the ancient woodland, which covered the Borders previously.

In one example of encouraging local forest ownership and changing perceptions, BFT acquired the opportunity to purchase a small woodland near a local village. The community was reluctant to buy the woods as they felt that community woodlands were about encouraging and holding parties and raves. ${ }^{10}$ BFT explained how local woodland could benefit the community and changed this preconceived notion that locally owned woods equated to raves and parties. The result was that Lindean Woods were bought with successfully secured grants and is now managed by the local community.

${ }^{10}$ An all-night dance party, which attracts large crowds and copious drug and alcohol consumption often resulting in antisocial behaviour. 


\section{Educational programmes}

A large focus of BFT is on educational programmes. Although BFT hopes to educate both sexes and ages on forestry, it may be inadvertently helping to encourage young women and men into forestry as Pat Tomlin found in her research on women in forestry that "outdoor work and visiting forests were powerful influences on career choice" (Tomlin, 2001). Much of BFT's work is with youngsters who have not yet selected their core school subjects and on the most part will not have concrete vocational aspirations.

The educational programmes the charity currently focuses on are:

- School grounds project - developing outdoor places for environmental and educational reasons. School grounds are developed so they can be used as outdoor classrooms.

- Taking children out into woodlands with guides to educate them about local wildlife and forests.

- Woodland road show - in partnership with educational rangers and professionals, BFT takes the woodland to schools. A local council bus is hired and decked out with forest goods; the bus can be themed to projects the class is currently working on, i.e. minibeasts. This has been very successful and over 75 percent of local schools have been visited so far.

- Forest schools - this idea came from Scandinavia. The aim is to take children out of the classroom environment one day a week into the forests. The children will learn new skills and it will be closely coordinated with the national curriculum. Facilities have been developed for the children to work at and there is shelter for bad weather.

- Youth groups - BFT works with local troubled youths who have been excluded from schools. The charity also works with youngsters with learning disabilities.

- Community learning - talks are given to local communities about forestry. An example was a presentation given to the local women's rural group, which in turn influenced many of the women to be involved in planting.

The Woodschool is another successful component of the Trust's work adding economic value to local timbers and forests. It is a separate wholly owned subsidiary of BFT. The Woodschool processes and sells local hardwood timber and provides workshop facilities for designers to establish a career in furniture making. Woodschool is now yielding a profit through timber sales, bespoke furniture commissions and through rental of workbench space; this profit is channelled back to BFT to support the work of rekindling a woodland culture. 


\subsubsection{The importance of initiatives like BFT in the United Kingdom}

In a report commissioned by the Forestry Commission, Rameststeiner et al. (2003) found that forests in Europe were generally perceived through impressions and feeling. Half of the people interviewed on their perceptions of forestry used positive connotations, e.g. peace and fresh air, but the other half used negative descriptions such as darkness and forest dieback. This study also showed that the term "forestry" was seen largely as a negative term. This, coupled with the fact that university applications for forestry-related courses are falling (UCAS, 2005) and United Kingdom university forestry courses are having to amalgamate with other land-based courses, i.e. Aberdeen University shows that there is much work to be done with changing perceptions on forestry and what the industry actually entails. Projects such as the BFT will educate people in how to use forests for recreation, conservation, commercial and non-commercial gains and to have a better understanding of the importance of local forests on communities.

Nicola says that responses on the whole to the projects being carried out by the BFT have been very positive with both adults and children and as a result visits to their land have increased. They have partnered with other organizations so their work can be emulated elsewhere within the United Kingdom.

When the Trust was established in 1996 there were only two community woodlands in the Scottish Borders, there are now more than 20 across the area all being managed by local people. This dramatic increase demonstrates the enthusiasm local people have for woodland resources. It also emphasizes the change in perception of how woodland and the forestry industry feature in society. New opportunities exist for participation and appreciation of woodlands and forests, and as awareness grows, more people of all ages are enjoying the benefits whether as a place to walk with the family or as a place to learn new woodland management skills and carve a career in forestry.

\subsubsection{Future Research on changing perceptions about forestry}

- Research on the stakeholders of similar innovative forestry organizations. An empirical study assessing changes in attitudes towards forestry and the industry over time.

- How have these organizations helped to shape career choices? Further research into the outcome of the educational projects with youngsters - can these schemes really encourage more women to join forestry?

- Look at the effect on innovative forestry organizations on a narrower scale. Research the effects on specific subsets such as sex, religion, ethnicity and the less able bodied. 


\title{
3.4 URBAN NATURE - PERCEPTION, EVALUATION AND ADOPTION BY TURKISH MIGRANTS IN THE NORTHERN RUHR AREA UNDER SPECIAL CONSIDERATION OF URBAN-INDUSTRIAL WOODLANDS
}

\author{
By Uta Hobn, Andreas Keil, Orhan Güles, University of Bochum, Germany
}

\subsubsection{Research design}

The perception, assessment and adoption of different types of urban nature by Turkish migrants living in the Ruhr area were systematically analysed. The focus on the population group of Turkish migrants is based on the fact that they constitute a higher than average proportion of the residential population in the direct environment of existing and potential urban-industrial woodlands.

The research design was structured into three phases. The first phase was composed of four submodules: "evaluation of literature and secondary statistics", "spatial analyses", "part-standardized interviews", and "expert interviews". In the subsequent phase of evaluation and assessment, the ascertained results were discussed with the local actors and residents in workshops.

\subsubsection{Interview of the residents}

With the help of a part-standardized questionnaire, primary surveys were carried out in all three project areas. The questionnaire is divided into four thematic fields. The 230 people who participated were selected by a random quota sample; 48 percent of them were women.

There are big differences in the way Turkish migrants perceive nature and urban nature. "Nature" is a term which has positive connotations (green 57.7 percent; trees 43.9 percent; forest 26.5 percent; beauty 17.5 percent; flowers 16.9 percent; etc.), whereas the existence of urban nature is often questioned by the interviewees (no/rare nature 24.4 percent; dense housing; etc. 19.5 percent). The way nature and urban nature are understood or perceived scarcely seem to vary with the sex of the interviewee. One difference is the word "flower", which is named by 70 percent of the women for both nature and urban nature.

A favourite place for walking is the park, mentioned as the most frequent activity in urban nature. The urban woodlands are also mentioned, depending on accessibility. Those interviewed who have a garden of their own use it to invite friends and to have a barbecue with the family. Gardens as a private area are a place to meet and communicate. They represent a kind of urban nature form that is most intensively used, if available: "If there is a garden, I do not need to go anywhere else” (I56, 19 March 2005). In all the areas studied, about 50 percent of those interviewed said they took advantage of this form of urban nature nearly every day. 


\subsubsection{Expert interviews}

Experts had questions put to them in both German and Turkish, in a public interview with a common theme. There were two phases to this. In the first exploratory phase, three experts from Gelsenkirchen were interviewed whose daily work acquainted them with the use and perception of urban nature of people with a Turkish migration background. In total, 17 experts were interviewed, all working in the field being researched and having either privileged access to information about the study groups, or to decision-making processes of the local authority or the area administration. The interviews aim to deepen and extend the knowledge the project team already had and to provide feedback to it.

All experts interviewed have stressed unanimously the high relevance of an open space near the residential area in densely populated inner-city quarters. According to them, the Turkish migrants like the urban nature areas and use them often. Although the industrial woodland areas are seldom visited, they do offer a large future potential for intensive use. Perception, use and assessment vary according to age and gender: the elder generation (first migrating) prefers private gardens to the public areas and uses them as, among other things, kitchen gardens; the younger second generation takes advantage of the public areas of urban nature much more often, for example by taking walks.

Whereas men will go to urban nature alone, or with other men to practise sports, women often stay in public urban nature areas only when they are with their families.

"Women deal with public space in a different way: If it is family related, if the children come with them, the open space outside the residential area is used" (integration office).

In nearly all the interviews, a topic had been the association of conservation with the religion. Most of the experts have shown interest in their institution or organization being involved in further projects for the adoption of industrial woodlands, with the proviso, however, that many of those interviewed are already taking part.

"We should like to do our best to help, in line what is possible for us" (migrants' own organization).

\subsubsection{Conclusion}

The study has shown a differentiated picture of the way the Turkish migrants perceive, assess and use urban nature. Nature, in general, is seen and evaluated much more positively than urban nature. Here negative associations such as noise and pollution are often mentioned, especially possible problems of soil contamination in the industrial woodlands. However, the important function of urban nature, i.e. the industrial woodlands, for densely populated inner-city quarters could be worked out clearly. These forms of nature play an important role in the improvement of quality of life. 
Two further main results of the study are an awareness of the religious influence on the assessment of nature and the wish for a greater degree of landscaping. In contrast to the Western population, it is obvious that the attitude to the daily use of nature by the Turkish residents has been strongly moulded by Islam; their religion allots great importance to conservation. At every stage of the study the Turkish residents predominantly wished for a redesigning of the industrial woodlands, parks, for example, with road networks, seating accommodation and improved hygiene through sanitary facilities and fountains. Differences in the use of the industrial woodlands were in evidence depending on the generation, gender and the level of development of the area. The Rheinelbe industrial woodlands in Gelsenkirchen are already well known, much frequented and popular. They are physically close to the district and special actions taken by the kindergartens and the schools are improving the industrial woodlands and especially in their implementation is a decisive factor.

There are seven recommendatons, which derive from the results of the study:

\section{Infobox: Recommendations for action}

\section{More information and communication, more transparent planning!}

The analyses have revealed a deficit information situation and a lack of multilingual communication that contribute to an underuse and adoption of the industrial woodlands. At the same time, there is an increased demand for transparency in planning. The confidence of the citizens in active participation can be gained by producing additional information and better communicating the current plan.

\section{Greater security in the woods!}

Both, those with a Turkish migration background and the experts, have described the industrial woodlands as insecure owing to the fear of violent attacks. Although these are subjective perceptions, such fears must be taken seriously.

\section{More gender-sensitive planning!}

The study clearly demonstrates the low use of the industrial woodlands by Turkish women and girls; when they do use them it is generally in the company of other members of the family. It is therefore necessary to ascertain the needs of females and to develop gender- sensitive concepts in common. Also needed is a closed-off protected area within the woodlands where women can go with their children.

\section{More cultural layout mix!}

By means of more landscape elements, road networks, the installation of seating accommodation and the setting-up of recreation areas, Turkish families can better use the woodlands. Seating accommodations, for 
instance marked broken-off tree trunks, can be creatively integrated into the concept. A landscape element, asked for by the Turkish participants because of Muslim rules on hygiene, are a water source or dispenser and a fountain. All other population groups, too, can benefit from such an installation.

\section{Stronger activation of kindergartens and schools!}

The direct contact made recently by Turkish families with some kindergartens and school groups has proved successful. However, a stronger and more systematic activation of the Turkish population through schools and kindergartens is advisable for the future. Thus, special skills that are necessary for a successful access to the field are acquired at an early stage.

\section{Stronger integration of the Turkish migrant community!}

A prerequisite for the continuous and successful activation of the Turkish population is the integration of the Turkish communities and the migrants' own organizations (mosque clubs, youth welfare, sports and culture clubs, etc.). These multipliers have already shown their interest in future cooperation and made a substantial contribution to the research process.

\section{Stronger participation of residents - research desired!}

For the sustainable planning and landscaping of the areas that also use the integration potential of the industrial woodlands, a greater integration of all population groups of the quarter with regard to age, gender and migration background is necessary!

\subsubsection{Summary}

Over the past decades, crucial changes have taken place in the perceptions, attitudes, demands and views on forests and forestry by society. Reviews, public opinion surveys, conference conclusions and recommendations, case studies and research results prove that women seem to have different perceptions on forests because they are more ecologically and societally aware and more critical about forestry measures. Conceptions of public participation and awareness raising on sustainable forest management should take these observations and survey results into consideration. Communication strategies should also be more mindful - that different approaches could be needed for different target groups. Sustainable forest management has to improve its social aspects and in doing so will learn that men and women have different attitudes to natural resources and their management. Women as decision makers and key consumers should be addressed and their attitudes and perceptions need to be taken into account and considered. It is highly recommended that research and administration groups should include the gender dimension of public perceptions in their agenda and work programmes. 


\section{MEANS AND ACTIONS}

\subsection{INTRODUCTION}

Since the United Nations Women's Conference in Beijing, the integration of gender equality into all major policy- and decision-making processes has been an overall strategy in most countries. As such, it must be considered as a powerful means to change the power balance in human societies. However, it needs to be implemented with definite actions at all societal levels. Those losing in power - generally men - must be convinced that gender equality is beneficial not only for society as a whole but also for them. The success of specific means and actions for approaching gender balance therefore depends on whether the people concerned perceive them as fair, legitimate and efficient. Consequently, there is no single "best" way to act that can be applied everywhere and by everyone. National, regional and local circumstances have to be considered and adapted to.

In the following sections, a number of different means and actions that already have been applied in the countries covered by this report will be presented. The first part examines political tools, the second discusses some initiatives in education, extension and research, and the last introduces a number of women networks in the forestry sector.

\subsection{POLITICAL TOOLS}

\subsubsection{Sweden}

\section{By Gunilla Tornquist and Gun Lidestav}

\section{The Equal Opportunities Act in Sweden}

In 1980, the Equal Opportunities Act was enacted in Sweden. The purpose of the Act is to promote equal rights for women and men in matters relating to work, the terms and conditions of employment and other working conditions, and opportunities for personal development at work (equality in working life). The Act states that employers and employees shall cooperate in pursuing active efforts to promote equality in working life. They shall strive in particular to prevent and eliminate differences in pay and other conditions of employment between women and men performing work that may be considered equal or of equal value. They shall also promote equal opportunities for wage growth for women and men.

Employers shall, as part of their regular activities, conduct goal-oriented work in order to actively 
promote equality in working life. Employers shall take whatever steps may be required, insofar as their resources and general circumstances permit, to ensure that working conditions are suitable for both women and men. At workplaces where there is no equal distribution of women and men in a certain type of work or within a certain category of employees, employers shall, in respect of new positions, strive in particular to recruit applicants of the underrepresented sex and shall seek a gradual increase in the proportion of employees of that sex.

Each year, employers shall prepare a plan of action for equal pay and therein report the results of the survey and analysis. The plan shall state what pay adjustments and other measures need to be implemented to attain equal pay for work considered equal or of equal value. The plan shall further contain a cost computation and a time schedule aimed at ensuring that the required pay adjustments are implemented as soon as possible and at the latest within three years. A report and an evaluation of how the planned measures were implemented shall be included in the plan of action for the following year.

To ensure compliance with the Act, there shall be an Equal Opportunities Ombudsman and an Equal Opportunities Commission. The Equal Opportunities Ombudsman and the Equal Opportunities Commission shall be appointed by the Government.

\section{Official report on gender equality in forestry}

Twenty-four years after the Equal Opportunities Act in 2004, a report about gender equality in the agricultural and forestry sectors in Sweden was presented by the Ministry of Agriculture, Food and Consumer Affairs. The report "Slowly advancing...Gender Equality in the Agricultural and Forestry Sector" (Ds 2004:39) does a fair job of reflecting the developments and the actual situation within these sectors. Furthermore, it points out that these sectors, with respect to gender equality, are lagging behind most other parts of Swedish society. This report was an outcome of the first gender equality plan by the Nordic Council of Ministers agricultural and forestry sector adopted in 2000 and revised in 2002. The report contains information designed to facilitate implementation at national level. Criteria used to define gender equality are:

- women's representation;

- income distribution;

- ownership and inheritance; and

- informal obstacles and structures. 
Additionally, the report contains proposals and recommendations on how to improve the situation by various means and in different subsectors. Proposals and recommendations of particular interest from gender equality in the forestry perspective are listed below:

- Draw up a special gender equality plan for the forestry sector. The plan should be drafted and implemented in cooperation with organizations active in the sector.

- Allocation of resources between the sexes in schools and recreation should be further analysed. Clearly defined aims and objectives should be drawn up and communicated to local government authorities, and activities should be followed on a regular basis. Forestry enterprises should be included in all statistical surveys of business activity in Sweden.

- The government should emphasis the importance of gender-equal pay rates in its dialogue with public authorities on gender equality concerns. Efforts should include a detailed study of the job titles and designation given to men and women and how these in turn affect pay award.

- National audit authorities should intensify their scrutiny of gender equality work in the central government administration by, for example, giving direct responsibility for gender affairs in the forestry sector to an officer in the Division for Energy, Forestry and Primary Industries. Furthermore, require that the National Board of Forestry's accounts be gender disaggregated. The directions should also set out clearly defined, measurable gender equality goals for skills provision.

- Enterprises, organizations and authorities are urged to draw up guidelines on representation and staff welfare aimed at enabling women and men to operate on equal terms.

- There is a need for more research aimed at identifying relevant, valid gender equality indicators and criteria in the forestry sector.

- The government should, in collaboration with representatives of the forestry industry, coordinate information about projects relating to rural development and women in enterprise in rural areas.

- Efforts must be made to foster a culture in which enterprises can flourish, particularly among young people. To this end, entrepreneurship should be promoted in education curricula and through government measures aimed at creating a more favourable view of entrepreneurship.

With respect to gender equality work within the European Union, Sweden endeavours to ensure that all policy decisions are prepared by a gender equality impact assessment. This should also apply to national policies in areas where Sweden should set a good example. 


\subsubsection{Political tools in Norway}

\section{Background}

In 1982 and 1983, female forestry students at the Norwegian University of Agriculture took the initiative to put women and forestry on the agenda (Egeland et al., 1983). Because of a change in a Norwegian law, in 1974 about one-half of future forest owners were expected to be women. In 1985, deans at forestry schools were concerned about the low rate of women at their schools and alarmed the Ministry of Agriculture.

\section{On the political agenda}

When Dr Gro Harlem Brundtland became Prime Minister of Norway in May 1986 (her second term), the country formed its first Cabinet with 40 percent women participating. The Prime Minister's view on gender aspects was clearly recognized in several areas of the governance of the ministries during the following years. In May 1986, Minister Gunhild Øyangen was appointed the first woman Minister of Agriculture. The minister expressed her immediate support to the new organization Women in Forestry, which was launched in autumn 1986, and became a strong supporter of the work to improve gender balance within the forestry sector. She believed that to achieve a better gender balance the ownership would need much information and motivation work, and described the establishment of Women in Forestry as a historical breakthrough concerning gender balance in Norway (Øyangen, 1987).

Since autumn 1986, it has been more or less politically impossible for leading persons in the ministries and organizations within the forestry sector not to support the ambition to increase the number of women within the forestry sector. But to discern if everyone genuinely has meant these expressions of support is another question.

In the following years, several political documents expressed concern about the largely male- dominated sector and the need for actions. The Committee on Agriculture and Forestry Policy highlighted gender balance as one of the main objectives of the Norwegian forest policy for the future (NoU, 1991: 2A). After reviewing the policy, the Cabinet emphasized that special measures were needed so that actual results - equal gender balance - could be attained within the sector (the Ministry of Agriculture, 1992).

The Ministry of Agriculture therefore, in the late 1980s and early 1990s, proposed a number of actions for achieving better gender balance within the forestry sector. The actions are presented in Annex III.

\section{Laws and regulations}

While some of the laws and regulations concerning gender balance are similar to those in other countries, others are unique. The laws concerning gender balance in Norway are listed in Annex III. In addition to the 
Gender Equality Act of 1978, there are two laws that are particularly important in the Norwegian forestry sector.

In 1974, the act regulating who would have the right to become the next farmer/forest owner by heritage was changed. Until then, the eldest son had the best chance of inheriting land. The new law, decided by Parliament in 1974, gave the rights to the firstborn child, regardless of sex. The law came into effect for children born after 1 January 1965, but everyone did not welcome it as a long tradition came to an end. The situation made many young women think rather seriously about whether they wanted to take over the property.

Since 1981, the Gender Equality Act has included a new section on gender representation rules, demanding that each sex be represented by at least 40 percent in all public committees, councils, boards, etc., appointed by a public body. For some years, the forestry sector was permitted (after application) not to meet this requirement due to the low number of women within the forestry sector. However, these exceptions have not been accepted for almost 20 years.

After 1 January 2006, the public limited companies have been forced by the Act of 19 December 2003 to meet the demand that each sex be represented by at least 40 percent on the Board of Directors (the Ministry of Children and Family Affairs, 2005). Similar requirements might be put on the cooperatives in the near future, including the forest owners' organizations.

At present, regional partnerships for forestry and equality are being tested in the county of Hedmark. This was initiated by Merete Furuberg and approved by the political county council June 2004. The first partnership meeting was held in January 2006. Both public and private organizations are taking part (Furuberg, 2006). The test will demonstrate how this new tool works to improve gender balance.

\section{Summary and conclusions}

The Norwegian government strengthened its focus on gender aspects 20 years ago and the Ministry of Agriculture became a strong supporter of the work to improve gender balance within the forestry sector. Political means were identified and several actions were taken, at least in the late 1980s and early 1990 s, to increase the share of women within the sector.

Lately, a number of laws and regulations have been changed in order to achieve a better gender balance in Norwegian society, in particular within the private sector. These changes also affect the forestry sector and are likely to be the most important tool to achieve gender balance among board members. However, no political tool with similar effect is in place that can give substantial help to improve gender balance among the employees within the private forestry sector. 


\subsubsection{The United States Civilian Labor Force}

The United States Federal government establishes personnel workforce objectives by which Federal organizations are rated, whereas the Federal Equal Employment Opportunity Commission (EEOC) provides regulation for these objectives. Federal agencies objectives are to reach parity with the Civilian Labor Force (CLF) percentages. The CLF establishes the overall number and percentages of women and underrepresented classes working in various jobs throughout the United States. The objective is for federal organizations to reach similar percentages in appropriate positions.

A federal organization such as the United States Forest Service employs foresters, biologists, engineers, forestry technicians and many other natural resource specialists. Annually, the Forest Service leadership and executives are evaluated and rated on the progression toward CLF percentages for similar positions that are held by women. The CLF is a formal regulatory process; however, early in the 1980s the United States Forest Service leadership recognized the need to ensure that women and underrepresented classes were represented throughout the agency, including leadership positions.

The agency deliberately took actions to encourage women and underrepresented classes into decisionmaking positions such as district ranger and forest supervisor positions. The early objective, along with CLF parity, was to build a critical mass of women throughout the agency, including decision-making positions. The agency not only developed training and programmes to that end but encouraged champions and mentors among the exiting leadership. Leadership and diversity training benefited the agency as a whole and increased the skills for collaboration and negotiation that has assisted all leaders in working with diverse interests.

\subsubsection{The gender mainstreaming strategy within the European Union}

Article 2 of the European Community Treaty provides that promotion of equality between men and women is a task of the European Community. Article 3(2) provides that it should aim to eliminate inequalities, and to promote equality between men and women in all its activities (also known as "gender mainstreaming"). There are three legal bases in the European Community Treaty for European Union legislation on equal treatment of men and women: Article 141(3) in matters of employment and occupation; Article 13(1) outside of the employment field; and Article 137 in the promotion of employment, improved living and working conditions.

\section{Integrating equality between women and men into all community policies and activities}

Gender mainstreaming is the integration of the gender perspective into every stage of policy processes - design, implementation, monitoring and evaluation - with a view to promoting equality between women and men. It means assessing how policies impact women and men - and taking responsibility to readdress them if 
necessary. Sound policies will make gender equality a concrete reality in the lives of women and men, creating space for everyone within organizations and communities, and will contribute to articulating a shared vision of sustainable human development and translating it into reality.

The commitment to gender mainstreaming needs to be taken to high political levels and needs to permeate whole organizations, whether it is the European Commission or a national or regional civil service. It should not be dependent on a few dedicated individuals, but rather it needs to be an automatic reflex throughout the organizational structure. It is important therefore that at the policy level the issue of gender equality becomes a visible and a central concern in policy and planning.

Gender statistics, indicators and benchmarks, as well as statistics disaggregated by sex, play an essential role in promoting gender equality. They are tools for gender mainstreaming, specially needed to monitor progress in implementing the gender dimension in different policy fields, and towards the goal of achieving equality between women and men. They make policymakers accountable towards citizens.

The Commission initially started working on gender mainstreaming in the early 1990s, and developed a more consistent approach following the United Nations Women's Conference held in Beijing, China, in 1995. Since then, gender mainstreaming has steadily grown in importance. It is at the heart of the thinking behind the European Commission's Framework Strategy on Gender Equality 2001-2005.

In years past, the European Commission has done important work on gender statistics and indicators in cooperation with EUROSTAT. It has also helped the High Level Group on Gender Mainstreaming in developing indicators for following up on the Beijing Platform for Action.

Table 42: The European Community Framework Strategy on Gender Equality

1. Introduction

2. The strategy

3. Setting the objectives

4. Tools and mechanisms
1. Gender equality today: towards an inclusive democracy

1. A gender equality framework strategy to embrace all policies and a programme in support of the framework strategy

2. Subsidiarity and complementarity

1. Promoting gender equality in economic life

2. Promoting equal participation and representation

3. Promoting equal access and full enjoyment of social rights for women and men

4. Promoting gender equality in civil life

5. Promoting change of gender roles and stereotypes

1. Reinforcing cooperation with the EU national gender equality authorities and coordination of the activities

2. Reinforcing of Commission structures

3. Reinforcing cooperation among the Community institutions

4. Strengthening partnership

5. Setting indicators and benchmarks

6. Ensuring information, reporting and evaluation 
In March 2006, the European Commissioner of Employment, Social Affairs and Equal Opportunities announced that gender inequality in the European Union will be tackled by introducing 21 specific activities within the next five years, which are outlined in a new gender equality roadmap published by the European Commission. The proposed Commission activities in the "Roadmap for Equality between Men and Women 2006-2010" include helping to set up a new €50 million European institute for gender equality, reviewing all existing European gender equality law, increasing awareness of gender inequality, ensuring gender equality is considered in all policies and pressing for better statistics. The roadmap aims to, inter alia, tackle the pay gap between men and women, support better work/life balance, eliminate violence and trafficking, support gender budgeting, and promote gender equality both within and outside the European Union.

The roadmap sets out six priority areas for action in the 2006-2010 period:

- achieving equal economic independence for women and men;

- enhancing reconciliation of work, private and family life;

- promoting equal participation of men and women in decision-making;

- eradicating gender-based violence and trafficking;

- eliminating gender stereotypes in society; and

- promoting gender equality outside the European Union

Each objective is followed by specific key actions designed to achieve the goal sooner. Actions include increasing awareness of gender equality in schools, promoting female entrepreneurship, establishing in 2007 an European Union network of women in economic and political decision-making positions, publishing a communiqué on the gender pay gap, and highlighting gender issues during the 2007 European Year of Equal Opportunities for All.

\subsubsection{Gender mainstreaming in National Parc Eifel, Germany}

The following brief summary demonstrates how the gender mainstreaming strategy was implemented into the daily routine of forest administration. For more information, see www.isoe.de.

\section{The pilot project "Gender Mainstreaming in the National Park Eifel" - the development of implementation instruments}

By Doris Hayn, Institute für sozial-ökologische Forschung (ISOE) Frankfurt, Germany

In 2003, the Ministry for Environment and Nature Protection, Agriculture and Consumer Protection (MUNLV) of North Rhine-Westphalia introduced the gender mainstreaming strategy into its organization. The pilot project "Introduction of Gender Mainstreaming in the National Park Eifel" is an essential part of the 
ongoing implementation of gender mainstreaming within the process of lean administration in North RhineWestphalia (NRW). The project was carried out by ISOE, and Dr Doris Hayn was the project leader.

From the vast scope of activities of the National Park Forestry Office, three domains were determined as test fields for the trial because they offered sound and manageable access to the new task of gender mainstreaming. The focus was placed on the focal points public relations, education and socio-scientific research, because these fields are well suited to demonstrate the integration of gender aspects and gender issues. Accordingly, the project was focused on developing implementation instruments that support the integration of the objective "gender equality" into all tasks and that allow the consideration of women's and men's differing interests and personal circumstances from the outset and on a regular basis.

\section{Development of the implementation instruments}

The development of the implementation instruments comprised two phases. The first project phase aimed at designing the implementation instruments. Based on the analysis and the summary of the resulting material, three sets of instruments were drafted: the gender-sensitive practice in public relations, equal opportunities in education and the integration of gender issues in socio-economic monitoring. The second project phase aimed at optimizing the implementation instruments.

The three implementation instruments are structured in a corresponding manner. They each include an introduction to the topic of gender mainstreaming, outlining the objectives and areas of application and providing advice on the handling of general conditions. The main part of the instruments includes concrete guidelines for the practical implementation, which are exemplified in a detailed manner. The elaborate instruments are supplemented by checklists, which allow time-saving gender checks during everyday work processes.

\section{Guideline for gender-sensitive practice in public relations for national parks - gender mainstreaming in public relations}

A gender-sensitive practice in public relations for national parks implies considering the differing interests and personal circumstances of women and men. Gender-sensitive practice in public relations is designed to equally address the needs of women and men and to be equally available to both. Furthermore, it should give a balanced presentation of women's and men's activities in the national park. 


\section{Conceptual framework for equal opportunities in education in national parks - gender mainstreaming in education for children and youths}

Equal opportunities in education for children and youths in national parks acknowledges the genderspecific socialization of girls and boys and is taken seriously in order to handle it in a gender-competent way. This includes equal access to educational offers by tailoring them to the interests, knowledge and experience of boys and girls. In this context, the gender and target group specific differences of the participants is systematically collected and analysed. Implementing gender mainstreaming in educational offers of a national park serves the objective of creating a permanent impression of nature and wilderness and a lasting inspiration for the subject of nature conservation among girls and boys and among young women and men as well.

\section{Guideline for integrating gender issues into a socio-economic monitoring in national_parks - gender mainstreaming in socio-economic surveys}

The implementation of gender mainstreaming in the context of socio-economic monitoring (SEM) considers the different personal circumstances and interests of men and women in the development and realization of SEM. The integration of gender issues into SEM forms a basis for gender-specific insights into the activities of a national park, especially in the areas of education and public relations. These insights can benefit gender-specific developments and advancements of the work in national parks. An SEM designed accordingly thus provides insights for improving gender equality, for instance equal access to public relations products and equal participation in educational offers.

\section{Assessment of the work process}

The intensive work process resulted in three instruments that offer practical guidelines for the everyday implementation of gender mainstreaming. They enable the systematic integration of the differing interests and personal circumstances of women and men, boys and girls, into the activities of the national park. The checklists are additionally helpful in offering a time-saving revision ("Gender Checklist") during everyday work. The tests of the guidelines further resulted in a multitude of best practice examples, concrete starting points and methods that can be applied for internal as well as external communication and that also support the transfer to other areas. Two factors were decisive for the successful project work: on the one hand, practical experience from national parks and other contexts of nature conservation formed the starting point for drafting the instruments. On the other hand, these drafts were tested in practical applications and accordingly revised. This was the basis for developing tailor-made instruments for the implementation of gender 
mainstreaming in national parks. A further factor for the work's success was the high degree of dedication among all project participants and the close and communicative cooperation between the national park administration and scientific monitoring.

Moreover, during the pilot project National Park Eifel employees acquired a comprehensive understanding of the gender mainstreaming strategy in general and its practical implementation in their respective fields of activity in particular. Their active cooperation in the project has considerably sensitized them for gender issues and has advanced gender competence. Furthermore, the examination of gender issues also stimulated creativity in everyday work and offered a view of professional aspects that reach beyond the project. Gender mainstreaming thus acted as eye-opener for professional work.

\section{Outlook National Park Eifel project}

The aim now is to continue and stabilize the gender mainstreaming strategy that was implemented in the National Park Eifel. Because National Park Eifel is a "forest national park", aspects of the practical fields of forestry and nature conservation were explicitly considered when the implementation instruments were developed. The instruments, mainly the "Conceptual Framework for Equal Opportunities in Education" and the "Guideline for Gender Sensitive Practice in Public Relations" are therefore suited for forestry as well as for education in the field of nature conservation and environment. Gender-specific differences have until now been only marginally taken into consideration in public relations and education in the field of forestry; gender and target group specific perspectives are rather limited in this field. Against this background, the application of these developed instruments allows existing activities and services in public relations and environmental and nature protection education in the field of forestry to advance and improve. It can be assumed that a gender and target group specific practice considerably contributes to augmenting the satisfaction of existing target groups and develops new target groups.

The high number of male environmental educators, mostly forest wardens and rangers, thus provide for positive multipliers in educating children and youths outside of school. As male role models they can add support to the female role models in schools (and homes), especially to boys. This, however, requires professional training in equal educational opportunities and in innovative youth work and work with boys. The gender mainstreaming strategy lends itself to being integrated into North Rhine-Westphalia's forest management, as this field is currently undergoing restructuring.

The project results also point out basic questions connected with integrating gender issues regarding research in nature conservation and forestry. The importance of integrated approaches becomes evident, 
especially with integrating the different perspectives of scientific disciplines (interdisciplinary) and the inclusion of societal practice (transdisciplinary). Such an advancement of science and research allows to act on the observable changes of theory and practice in nature conservation. An approach integrating ecological, social and economic issues within the concept of sustained development recommends itself. Current developments in the field of forestry can also be taken up, for instance studies on the perception and image of forests and forest cultivation and on different appropriation forms of urban forests. Such studies are important starting points for the development of communication concepts and public relations activities as well as for trend-setting projects of forest design and nature conservation planning, which are participative and based on dialogue. The increase and promotion of integrative nature conservation and forestry studies can make a basic contribution to the (re-)defining of objectives and tasks in the practical fields of forestry and nature conservation. The integration of gender issues thereby focuses on questions of social differentiation, i.e. questions of the different actors and target groups with their differing interests, perceptions and needs as well as questions of the social dimensions of nature conservation and forests. The full potential of integrative perspectives and differentiations is currently, however, not being tapped: compared with research geared to the natural sciences, socio-scientific as well as inter- and transdisciplinary research systematically integrating gender issues is still scarce.

\subsection{GENDER ISSUES IN EDUCATION AND RESEARCH: CASES AND EXAMPLES}

By Siegfried Lewark

\subsubsection{Introduction}

The gender situation in a sector is, to a large extent, influenced by education, research and extension. Thereby gender issues are made visible. Awareness, openness and attitudes towards gender questions are influenced. At the same time, the current situation of gender equality and gender balance in the sector is reflected by the gender situation in the institutions providing education, research and extension. This situation may be seen from the data on women's and men's participation on different levels in these institutions. On the other hand, the activities of the institutions - courses and research projects - their types, objectives, numbers and acceptance as well as their approaches, contents and methods demonstrate the state of gender awareness within the institutions and to a certain extent the sector.

Therefore, it is important to focus on gender representation in forestry institutions and forestry curricula and gender-related contents in education, research and extension. In other words: What are the proportions of 
women and men and their roles? What are their perceptions and focus in connection with gender questions in their activities?

In this section, examples of information available on gender issues in education and research ${ }^{11}$ have been collected. This comprises:

- gender issues and courses in forestry curricula, and

- gender research in forestry research.

Data as noted above have mainly been included in the respective texts in Chapter 1:

- enrolment and graduation of women and men in forestry curricula, and

- gender representation in forestry institutions of education, research and extension.

The examples indicate that numbers and participation of women in the forestry institutions of education, research and extension are slowly growing, but it is still a men's world. Gender issues today are already included into education, research and extension to a limited extent, but still far from the weight they should have according to the importance of these issues in the forestry sector.

\subsubsection{Do gender-related factors influence students' choice of courses at the Faculty of Forest Sciences, SLU, Umeå?}

Mulualem Tigabu and Robert Nygard; Swedish University of Agricultural Sciences, Faculty of Forest Sciences, Department of Silviculture, Umea

When one of the promoters of this study studied at the Royal College of Forestry (now SLU) in 1969 it was a breakthrough year for female forestry students as the number of female forestry students had increased by 300 percent. In addition, before that time only one woman had attained a Master of Science degree in the forestry programme. Today, about 30 percent of students are women, but forestry is still a man's world. Dedicated to the vision of a better future for the Swedish forestry with the best students, irrespective of gender, the department directors of studies at the Faculty of Forest Sciences (SLU) in Umeå were convinced to apply for subsidies to analyse if, and in what way, gender-related factors influence the studies of forestry students. The authors are happy to conclude that negative gender-related influence seems to be a minor problem. At the same time, the results of the study point out how gender issues could be treated in an even more effective way in the future education at the faculty.

The result from a questionnaire answered by 63 students ( 68 percent male) sampled at four courses in spring 2004 showed no indication that the teachers' gender position, the course content or ratio of males and

\footnotetext{
${ }^{11}$ The limited information available on extension is included in Chapter 1 (Norway).
} 
females at the courses would influence students' choice of courses. The female students were overrepresented in biology courses and male students in technology courses. It was found that personal interest in the course subject was the most important criteria for choice irrespective of the sex of the students. No gender difference was found for dropping courses, most often this was due to overlapping with other courses and it generally took place before the course started. Of the male and female students, 86 percent and 79 percent, respectively, did not consider it important to address gender issues during the course and they were not in favour of including the teacher's attitude in the course evaluation. Some few written comments expressed the attitude: If you don't have a gender problem, don't create one. Among the nine students who were in favour of integrating gender issues in the course, at least in its evaluation, five were male. Two of their comments included: "It could be valuable for a teacher to be aware of his personality" and "A gender perspective on all courses could be an interesting option if it is professionally done". Male and female students have almost the same ranking concerning their expected future professional areas. "Management, planning and administration" received the highest rank from both men and women while "marketing" received the lowest rank from women and "research, planning and administration" the lowest rank from the men. Both male and female students considered a separate gender course to be the best way to address the question of gender.

\subsubsection{Gender issues in forestry curricula - results from surveys in 2002 and 2004}

By Siegfried Lewark.12

\section{Gender studies as a teaching subject worldwide}

An Internet search on gender studies as a subject of university learning and teaching gives a vast number of examples, ranging from single courses to comprehensive study programs, collections of course material and links to further searches. Additional information though was not found on gender issues in forestry courses exceeding the information collected in our survey. The search was especially focused on searching for elearning courses as an Internet-based course on gender and forestry has been developed and is being offered at the University of Freiburg (Lewark, 2006).

Of the websites, only four have been selected (all revisited in early 2006):

- Welcome to the Internet for Women's Studies: www.vts.rdn.ac.uk/tutorial/women;

- Syllabi on the Web for Women- and Gender-Related Courses: www.umbc.edu/cwit/syllabi.html;

\footnotetext{
${ }^{12}$ First published: Lewark, Siegfried (2006): Learning by doing - and a product to end with: E-learning gender course. Wageningen: Proc. Forestry education: between science and practice. Symposium of SILVA-Network and IUFRO-Groups S 6.15-00 (education group), S 6.18-02 (education, gender and forestry) and S 6.06-04 (education and research in silviculture). Under prep.
} 
- Women's Studies Courses via the Internet, Syllabi, and other Course Materials: www.library.wisc. edu/libraries/WomensStudies/curriculum.htm; and

- Gender and Women's Studies for Africa’s Transformation (GWS Africa): www.gwsafrica.org/ about/index.html.

A closer look reveals a dynamic situation. Although many new course projects are emerging, many of these cases are not well established and are not updated after initial project funding.

Ways and examples of implementing gender issues into forestry curricula: preliminary results from worldwide surveys (2002 and 2004)

The International Union of Forestry Research Organizations (IUFRO) unit Education, Gender and Forestry (6.18.02) has been collecting basic information about gender issues in forestry curricula as no known published information has existed on this subject. As a first pragmatic approach a basic questionnaire (see Lewark, 2004) was developed in 2002 and sent to colleagues using the IUFRO mailing lists (gender and forestry mailing list and a list of IUFRO staff). More than 800 questionnaires were distributed, including an unknown number with double addresses, as colleagues had been asked whose interest principally was assumed. In 2004, the questionnaire was again sent out because the response rate in 2002 was low.

Table 43: Numbers of courses including gender issues named, by country

\begin{tabular}{llll}
\hline Australia & 4 & Nigeria & 1 \\
\hline Austria & 2 & Norway & 2 \\
\hline Canada & 2 & Poland & 1 \\
\hline Denmark & 1 & Sweden & 5 \\
\hline Germany & 1 & Switzerland & 1 \\
\hline Ghana & 2 & Tanzania & 1 \\
\hline Honduras & 1 & Zambia & 1 \\
\hline India & 1 & USA & 6 \\
\hline
\end{tabular}

The number of courses that include gender issues in the school's curricula are listed by country in Table

43. Altogether there were 57 respondents (only 38 in 2002).

The 57 questionnaires showed that 32 courses included gender issues within the forestry curricula, which had been answered by 29 respondents. Nineteen of the courses included "implicit" ${ }^{13}$ gender issues (Figure 16), and only nine dealt with "explicit" issues (four were unstated).

In most of these cases, instructors themselves answered. The negative answers (not included) came from colleagues from more than 20 different countries who were obviously interested in the topic. As the gender of

\footnotetext{
${ }^{13}$ Implicit - courses with topics such as forest policy, including gender issues; explicit - gender issues main content of course and named in the title.
} 
the respondent had not been asked for and the names do not always give a clue, the exact numbers of answers given by women and men cannot be estimated; however, more women seemed to reply.

Of the 32 courses that included gender issues, 21 were offered regularly, 14 were compulsory courses, and 12 were electives (6 not stated). All of the courses "explicitly", including those that deal with gender issues, are electives.

Figure 16: Number courses, including gender issues implicitly or explicitly
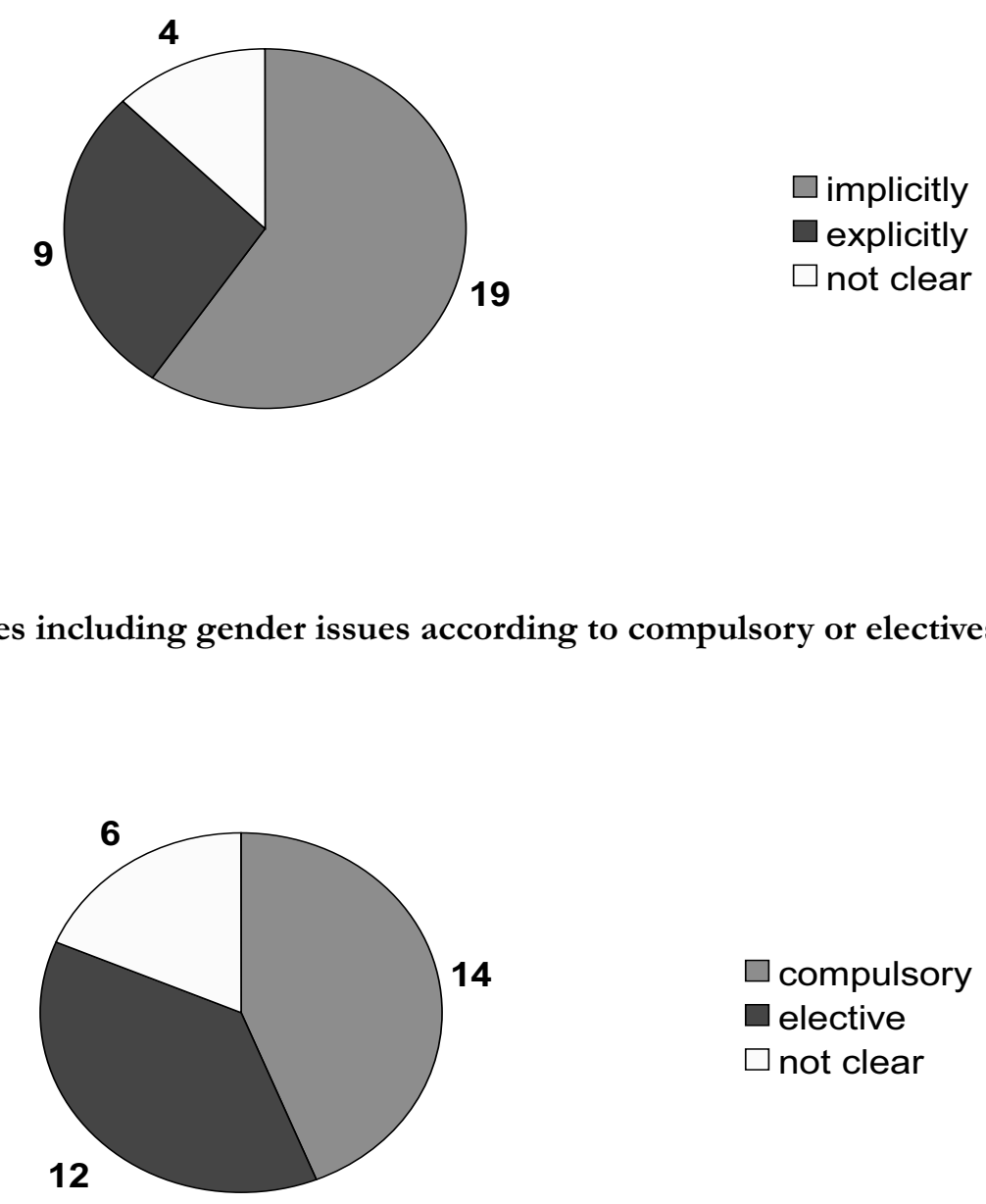

The statistics from Figures 11 and 12 initially give an impression that gender issues in curricula of forest sciences are important. Tracking development would be of interest, as well as collecting course descriptions and teaching methods. The courses held at the University of Freiburg from 1999 to 2003 have already been presented as an example (Lewark, 2004), and have since been developed into an Internet course (cf. Lewark, 2006). 


\section{Conclusions}

Although few responded to the questionnaire, both in 2002 and 2004, the team was still able to draw conclusions from this study, especially from the comments that were made by university teachers and IUFRO officers:

- a limited number of courses included gender issues or were explicitly devoted to gender issues in forestry curricula;

- teaching gender seems to be a special subject; and

- broaching gender issues is often considered women's business.

The experiences showed that prerequisites for successfully teaching gender issues to forestry students are:

- strong support structure;

- committed teachers; and

- interested students.

Gradually gender issues in forestry will become visible and acknowledged, including in the way it is learned and taught. Will this show a change in thinking? The IUFRO unit will continue gathering information and broadening the views, and the next phase will concentrate on collecting and analysing course descriptions.

\subsubsection{Gender studies - a new subject in forestry curricula: the University of}

\section{Freiburg, Germany ${ }^{14}$}

By Siegfried Lewark and Marion Karmann

\section{Women studying forestry in Freiburg}

The number of female students studying forest sciences at the University of Freiburg and at three other German faculties of forestry has been increasing since the 1970s. In the past, women had enrolled in limited numbers, as described in more detail by Lewark (2003).

The proportion of women in forestry sciences in Germany has been declining: decreases have been noted at the student level, and the research and professorial levels as well, which is a quite typical picture for curricula with a traditionally male dominated education and field of profession.

\footnotetext{
${ }^{14}$ First published: Lewark, Siegfried (2004): Ways and examples of implementing gender issues into forestry curricula. In: Konijnendijk C.C., Schipperijn J., and Hoyer K.K. 2004. Forestry serving urbanised societies. Proceedings of the IUFRO European Regional Conference, organized in cooperation with EFI, Copenhagen, 27-30 August 2002. IUFRO World Series No. 14, IUFRO, Vienna, pp. 391-399. http://www.iufro.org/publications/series/world-series/worldseries-14. 
Figure 18: Proportion of women among students, researchers, and professors at the University of Freiburg (winter semester 2000/2001)

students of forest sciences

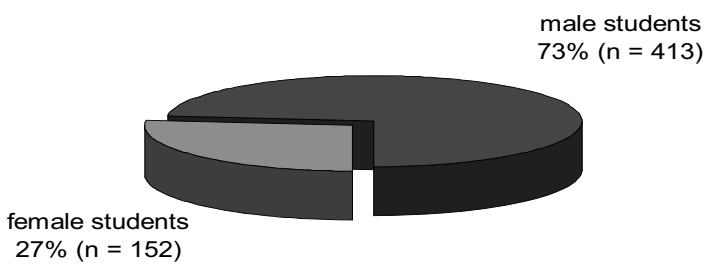

researchers in the faculty of forest sciences

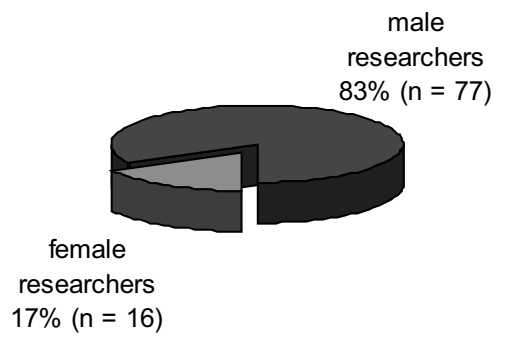

professors in the faculty of forest sciences

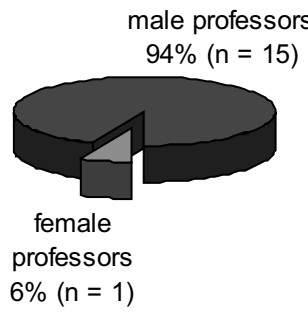

In recent years, the proportion of female students has been at about 30 percent, with about 500 students in the diploma curriculum of forest sciences, and close to 40 percent in the master's programme on sustainable forestry and land use management.

The Freiburg faculty has a policy of welcoming female students to the programme and specially creates positive messages for them - for example, photographs of women students working alongside male students. 


\section{Gender issues in the forestry curriculum}

In 2000, the University of Freiburg opened the Center for Anthropology and Gender Studies (http:// www.uni-freiburg.de/zag), and introduced a new curriculum on gender studies. Contributions from the faculty of forest sciences include new courses on women's work and careers in forestry as part of the subject forest work science (seven times between 1999 and 2003; since 2004 replaced by an e-learning course). ${ }^{15}$

The focus of the courses has changed as shown by title changes:

- Women's work in forestry

- Gender analysis in forestry

- Female careers in forestry

- Introduction to social science methods: the example of women's work in forestry

The course on women's work in forestry ${ }^{16}$ has been organized as a one-week block, which according to curriculum regulations in Freiburg, means 20 contact hours and 20 hours of self-study; two ECTS credits are given to students upon successful completion of the course (Figure 17).

Figure 19: Characteristics of the first gender study course at the University of Freiburg, winter 1999/2000

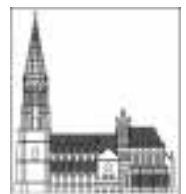

\section{Gender studies in forestry curricula: Freiburg}

\section{Characteristics of course „women's work in forestry“}

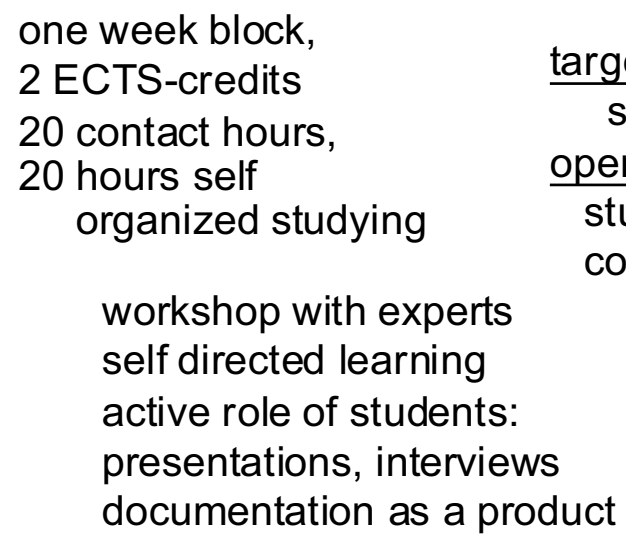

target group:

students of forest sciences

open for:

students of gender studies, continuing education

student's task:

sketch of a relevant research project

In later courses, students were asked to prepare a relevant research project, which students could realize after completing the course for school credit.

\footnotetext{
${ }^{15} \mathrm{cf}$. next text.

${ }^{16}$ First developed by Siegfried Lewark and Marion Karmann, with participation of other teaching staff.
} 
Table 44: Matrix for discussing topics

\begin{tabular}{|l|l|l|l|l|}
\hline \multicolumn{1}{|c|}{ female } & $\begin{array}{c}\text { forest } \\
\text { workers }\end{array}$ & foresters & $\begin{array}{c}\text { forest } \\
\text { owners }\end{array}$ & contractors \\
\hline $\begin{array}{l}\text { careers, employment } \\
\text { working profiles }\end{array}$ & & & & \\
\hline $\begin{array}{l}\text { working conditions } \\
\text { stress \& strain }\end{array}$ & & & & \\
\hline $\begin{array}{l}\text { motivation \& attitudes } \\
\text { job satisfaction } \\
\text { social relations }\end{array}$ & & & & \\
\hline $\begin{array}{l}\text { state of knowledge } \\
\text { research questions }\end{array}$ & & & & \\
\hline
\end{tabular}

The target group was students of forest sciences, including students in the master's degree programme on sustainable forestry and land use management. It was open for students of gender studies and for participants from other professions as a continuing education course.

The seminars were guided by experts, requesting active student participation and self directed learning. Students were expected to prepare presentations, interview specialists and document outcomes of the course. The matrix of table 44 explains the topics of discussion during the seminars.

Professional women from forestry, journalism and related-gender fields shared their professional experience with male and female students of forestry. In "workshop" style, information was collected on the statistics relating to women in forestry, published experiences, their self-understanding in their roles and women in forestry organizations in Germany and in other countries.

The gender courses have been accepted as normal courses within the elective part of the curricula of forestry. About half of the participants have been male and female students so the latter have been slightly overrepresented as compared with the proportion of all female students of forestry. The focus in the respective courses is always discussed and set together with the students and the discussions showed a clear reflection of the roles that can be expected in forestry, especially on the part of women themselves. The participants were highly engaged, which was evident from the active participation and the assignments chosen. Because of this commitment, the courses and their contributions are quite well documented in brochures.

These block courses will find their continuation in forthcoming semesters as an e-learning course (see box), and also for merging (female) forestry aspects into initiatives for women research and training courses within "Gender Studies" within and outside the University of Freiburg. 


\section{Learning by doing - and a product to end with: E-learning gender course ${ }^{17}$}

By Siegfried Lewark

\section{Abstract}

A new international e-learning course on gender and forestry was held in the winter semesters of 2004 and 2005, first as a blended course at Hedmark University College, Norway, and then at the University of Freiburg, Germany. Based on earlier courses held at the University of Freiburg, this course was developed into an e-learning course, with physical presence of four days at the beginning and Internet-based learning and teaching throughout the following five months (so-called blended course); students received five ECTS credits. At the end of the course, students were expected to create a booklet with life stories of women in the different professions in and around forestry.

The courses started with a presentation and a discussion of basic information on the state of gender issues in forestry, which was followed by a methodical introduction. Afterwards the courses focused on living situations and professional careers of women and men in the different levels of forestry - students interviewed forestry professionals and wrote life stories of them, and later those stories were compiled in an internal brochure. Interviews and life stories lead to understanding conditions of professional biographies as well as the attitudes and experiences behind them.

The international approach resulted in a broad representation from different countries: In the first course, participants came from Nepal, Norway, Slovakia, Venezuela and Germany. The blended setting with its approach of learning by doing and the resulting brochure has led to very active students' roles and an open and creative learning climate.

The second course in the winter semester of $2005 / 2006^{18}$ included a pure Internet group. This is evidence that many potential participants are interested in the course but are not able to come to Evenstad or Freiburg for the starting phase. Although the participants in an Internet group would not profit from the advantages of the blended setting, we tried to realize a good deal of the concept of blended learning and achieve a good learning success.

\footnotetext{
${ }^{17}$ Abstract from: Proc. "Forestry education: between science and practice. Wageningen: Symposium of SILVA-Network and IUFROGroups S 6.15-00 (education group), S 6.18-02 (education, gender and forestry) and S 6.06-04 (education and research in silviculture)", under prep.

${ }^{18}$ This course started with 28 participants and will be in its final phase in spring 2006.
} 


\subsubsection{Gender does matter: studying corporate culture and the possibilities for gender-sensitive reforms in Germany's forest services ${ }^{19}$}

By Maria Hehn, Till Westermayer and Siegfried Lewarke ${ }^{20}$

\section{"wa'gen" - a joint gender research project of the Universities of Lüneburg and Freiburg}

Forests have taken and still take an important role in society, in an economical but also in a political, social, cultural and religious sense. Recently, two diverging trends have been noticed:

- a change in societies' perceptions of forests and forest functions, moving away from the strictly economical view to a more holistic perception including political, social and environmental interests; and

- globalization and the consequences of neo-liberalism in politics have led to the outsourcing of work, the privatization of some state forest services and a substantial reduction of personnel, in order to strengthen the economical functions of forestry.

As a consequence, the mission of state forestry services needs to be redefined and the organizational structure changed. At the same time, other developments have taken place in society, especially with respect to equal opportunity policies and the consideration of gender aspects.

The joint research project wa'gen (from wald = forest and gender; "wagen" in German means "to dare, to risk" as well as "vehicle, carriage") started in June 2005. The project is a cooperation between the universities of Lüneburg and Freiburg.

\section{Objectives and consequences}

The research at the University of Lüneburg focuses on conceptual ideas and perceptions of nature and gender, and on the dialectics of occupational images and their reality, both concerning the transfer of environmental and forestry-related knowledge by forestry organizations.

The research at the University of Freiburg focuses on patterns of corporate culture within the state forest services. The "corporate culture" of an organization is defined as the set of conscious and subconscious perceptions of men and nature, of values and norms, of rules and attitudes, of customs and traditions commonly shared by the majority of the organizations' constituents. Thus, the corporate culture determines the self-image und the self-conception of the organization and its members, the reception and the perception of its natural and societal environment and due to its subconscious character, corporate culture is highly

${ }^{19}$ Extracts from: ILO, Forworknet Update 12, in print.

${ }^{20}$ Dr Maria Hehn is Senior Researcher, Till Westermayer (M.A.) is Junior Researcher and Siegfried Lewark is Professor at the Institute of Forest Utilization and Work Sciences of the University of Freiburg, Germany. 
effective in controlling the way how members of the organization think and act. This is of particular interest from the viewpoint of gender ratio (as defined by the number of male and female civil servants within the forest services) and gender relations (as embedded in organizational practices and perceptions about women).

A main objective of the research in Freiburg is to establish a historical reconstruction of corporate culture in German state forest services. To understand current gender ratios and relations, patterns of corporate culture in state forest services will be analysed, using a historical approach to reconstruct the underlying norms and mechanisms. Particular attention will be paid to (sub)conscious standards of qualification. We assume that there are patterns that led - and still lead - to the exclusion of women from the services. We also assume that these patterns also led - and still lead - to a unilateral and partial view of nature and forests, different from society's views and needs and restricting the potential for understanding as well as for change.

The historical approach will be complemented with the study of current gender relations in the forest services, using theories and methods of organizational sociology. First results of the project are expected in mid-2006. The results will lead to recommendations for a gender-sensitive implementation of the current organizational reforms in state forest services.

\section{Cui bono? Or: the relevance of gender research}

The question of relevance can be answered from two different points of view, a national and an international one.

\section{The national point of view}

We assume that gender ratio and gender relations within a public organization like the state forest services can be considered as an indicator for the compatibility between an organization and the society (as its social environment). Considering the political goal of equal opportunities in employment policies and gender aspects, a low representation of women indicates a need for reorganization and improvement - for example, with the help of gender mainstreaming. The final goal and result should then be an enhancement of the quality of understanding between the forestry organization and society.

\section{The international point of view}

Gender relations as an indicator for a certain corporate culture can be used as a key to understand similarities and differences in corporate cultures of forest services in different European countries. For example, the percentage of women forest rangers and of female employees within the Forest services in Portugal is much higher than it is in Germany. Gender relations are deeply rooted in the different corporate 
cultures and national traditions. With the increasing significance of European decisions on forestry (e.g. FFH guidelines, certification of wood and wood products, Kyoto Protocol and Process, MCPFE), the differences between the tasks, cultures and structures of the national forest services become increasingly relevant.

Therefore, the integration of the national forest services in a wider European network is inevitable. A thorough understanding of the different corporate cultures will facilitate this integration process.

Research on gender relations is a key for designing a sustainable socio-economic framework for both a national and a European forestry perspective.

\subsection{NETWORKS ON WOMEN AND FORESTRY}

\section{Introduction}

Clusters, networks and innovation systems are terms used for describing relations. Relations can be between individuals and companies and other actors, and the relations are supposed to in different ways, strengthen the individuals and companies' development. Networks are about relations that will be maintained over the long term; however, the purpose of a network is not just to create a network.

Informal and formal networks of women in forestry have existed for some years in a number of countries. They have provided invaluable support by giving women an opportunity to exchange their views and experiences on forestry. Female forest owners have responded to extension programmes specifically tailored for and targeted at them.

The information provided suggests that the first female organizations in forestry were established in Norway (1986), Germany (1987) and Sweden (1991). Furthermore, Norway and Sweden were the first countries, compared with other countries, where gender issues were discussed and worked on. This has helped women in the forestry sector to establish their own networks.

The networks of women in forestry in these countries has also served as role models and inspired women in forestry in other European countries to start their own networks. However, networking among women in forestry still needs to be developed further as the forestry sector is still male dominated.

It should be emphasized that such networks are not meant to be arenas where women participate instead of taking part in the traditional and decision-making forestry arenas dominated by men. Women's networks are seen as a supplement as women definitely have to be present at the decision-making arenas.

In several countries "women in forestry" networks do not yet exist. However, they should be established as a tool for increasing women's involvement within the forestry sector. 


\subsubsection{Networks in Sweden}

\section{By Gunilla Törnquist-Hedström}

Sweden has several different networks for women in forestry. Organizing women in forestry throughout the whole country is "Spillkråkan" (Black Woodpecker). Black Woodpecker (Spillkråkan) is an association for female forest owners founded in 1998. When female forest owners were trained - with European Union subsidies - in environment friendly forestry, they decided to establish a female support network to strengthen their role and receive greater recognition within the forestry sector. Today, most of the Black Woodpeckers several hundreds members live in cities and manage a forest elsewhere in Sweden. The association has three active "subsidiaries" in middle-sized cities throughout the country.

The goals of Black Woodpecker are:

- to strengthen women's influence in the Swedish forest industry;

- to increase knowledge and awareness of environment friendly forestry; and

- to build a communications network for women to exchange experience and develop knowledge.

The activities range from extension courses that raise knowledge about forestry issues to field studies in Sweden and abroad. Working in smaller groups, dealing with specific issues has been one of the Black Woodpecker's ways to increase knowledge.

One of the working groups, "Krax" (the sound the bird makes, in Swedish), realized that the timber companies that bought timber from the members did not have any women on the boards of directors. After some spectacular actions, including visits to annual board meetings of the largest timber companies, all timber companies in Sweden now have at least one woman on the board of directors. Through a newsletter for the members and a website all members are kept well informed. Through intensive work with public relations and the media, the Black Woodpecker has succeeded in many ways to gain public attention and achieve its goals. For further information, see its website: www.spillkrakan.se.

\section{Skogägarkvinnorna}

The Forest Owner's Association (LRF Skogsägare) also has a network for female members. One of its goals is to make women more visible in the forestry sector; another is to increase the number of women on the boards of the regional Forest Owner's Associations. For more information, see the website at www.lrf.se.

In addition, a number of regional women's networks exist in Sweden. The oldest one, founded in 1991, is Grenverket i Blekinge, which has organized about one hundred women interested in forestry and living in Blekinge, a county in the southeast of Sweden. Grenverket i Blekinge has many different activities, some of 
them with LRF Kvinnor (LRF Kvinnor is part of the Federation of Swedish Farmers). More information can be found on its website at: www.grenverket.se.

Established in 1996 in the northern part of Sweden, Grenverket is a network for women working in the forestry sector. This network was created to keep forestry-educated women in the sector after discovering that women left the sector after having experienced discrimination.

Dryaderna was among one of the first networks for female forest owners and started in 1996 in the west and south of Sweden, in the counties of Halland and Småland. Dryaderna works for raising forestry knowledge among women, who are either interested in forestry or who stand to inherit forests at some stage in their lives.

In Sveaskog, a forestry company owned by the Swedish state, the women employed in the company have started a network to encourage and strengthen each other.

Established in 1993, Kvist (Twig) is a network for women working in the forest industry. The network operates with a big idea in mind - how to attract young people, especially young women, to the industry, and to present role models of female forest industry employees.

These networks are examples of how women in Sweden's forestry sector have joined together to change women's situation in a male-dominated sector. They have, to a large extent, given women increased self-respect, regardless of whether they are a forest owner or working in a forest organization. The networks, together with the launching of the research of Gun Lidestav, SLU Umeå about female forest owners, have started to change women's situation for working in or owning a forest in Sweden.

\subsubsection{Slovakia}

By Merete Furuberg

\section{The Association of Women Foresters - History and main objectives of the association}

The Association of Women Foresters, established in 2001, is a voluntary, non-governmental organization that provides information and assistance to women in forestry regardless of race, nationality and religion.

Its main objectives are:

- to protect and develop the personality of woman, to defend equal status of women - family members, political, economic, social and cultural life;

- to organize formal and informal meetings in order to obtain information and exchange experiences in the field of self-realization of its members in rural areas, in business and labour opportunities;

- to ensure professional seminars to increase information level for environmental and rural questions; and 
- to work with the general public and increase the number of voluntary members in the field of nature protection, especially work that focuses on children.

The association provides membership for women who are 18 or older when they agree to the association's statutes and programmes. The organizational structure of the association corresponds to the territorial divisions within the Slovak Republic. The members elect a chairperson and the management of the association must be guided by the law.

In 2005, the association concentrated on organizing the fifth edition of the "Slovak forest Games" for children and youth clubs, and the fifth edition of the "Green Camera" a children's nature-photo competition.

In the future, the association wishes to implement European projects that aim at cooperating with similar organizations in the field of equality and supporting rural and environmental surroundings. Each year, the association proposes national projects with Slovak agricultural and forest authorities to foster its activities. It aims to engage the professional and nonprofessional public in their activities.

\subsubsection{Lithuanina}

\section{By Merete Furuber}

\section{Lithuania - The Organization "Women in Forestry"}

The organization Women in Forestry in Lithuania was founded on 15 May 2004. Its members are private forest owners, entrepreneurs, researchers, foresters, forestry officers and students. In Lithuania, the role of women in forestry has not yet been analysed. Thus, the organization will strengthen collaboration between the members and create the basis for joint activities and solving problems.

According to the Forest Act of the Lithuanian Republic, forests are divided between the state and the private sector. The structure of forest ownership has changed because of the ongoing land-reform process since Lithuania regained independence. The private forest sector has 202000 forest owners who altogether own 630000 hectares of forest; an average size of a forest holding is about 4.5 hectares. Private forests comprise 30 percent of the total forest area, a figure that is projected to increase from 40 to 47 percent in the future. Furthermore, forest owners who are more than 70 years old account for 30.7 percent. Although more than half of private forest owners are women (52.2 percent), their role as private forest owners and their impact to the management of forest holdings are not clear. 
The objective of the organization: To strengthen the role of women in the forestry sector.

It aims to:

- analyse the impact (or role) of women as private forest owners and entrepreneurs to forest management;

- stimulate women private forest owners to participate actively in forest management;

- collect statistical data on women as researchers, foresters, forestry officers and students in the forestry sector;

- assess the working conditions of women in the forestry sector in relation to the different organization types, education levels and job content;

- develop training and study material for women as forest owners;

- initiate training courses for women forest owners and entrepreneurs;

- develop an exchange platform on the Internet and thus facilitate communication between women researchers, foresters, forestry officers and students; and

- develop cooperation between similar organizations in foreign countries.

\section{$150 \quad$ 4.4.4 Networks in Germany}

By Renate Spaeth

\section{“Women in Forestry" - Germany}

In April 1987, some 80 women, mostly students of forestry at that time, met for a weekend to discuss the current situation, views and needs of women in forestry. As a result of this first meeting, a network was started. Every year, women in forestry meet for at least one weekend. In 1993, the association "Women in Forestry" was formally founded. The annual meetings are a mixture of exchanging experiences, and discussing in working groups specific topics such as:

- positive action plans for women;

- self-conception of women in forestry;

- women, jobs and children;

- public relations;

- language and discrimination;

- where and what area to work in after graduating; and

- organized excursions into nearby forests and landscape. 
German female foresters have always been active in organizing international meetings of women in forestry and visiting other countries. They take part in national forestry board discussions such as the discourse about the national forest programme of Germany. Women in Forestry aims to be a lobby organization for all women working in forestry regardless of their education or work position.

\section{Interest group "female forest owners in Nordrhein-Westfalen"}

In Nordrhein-Westfalen, a region in Germany with more than 18 million inhabitants and a forest cover of about 25 percent, nearly 70 percent of the forests are owned by private forest owners. In total, a number of 150000 people own forests, with an average of four hectares per owner.

Exact data about the distribution of male, female and joint ownership of men and women do not exist, but it is estimated that between 14 and 20 percent of the forests are owned by women.

In June 2002, the Forest Research Institue (LÖBF) of Nordrhein-Westfalen, which is also responsible for training courses to private forest owners, invited female forest owners to take part in a seminar to discuss and exchange their views on forestry and on ways of managing their forests.

The seminar was inspired by the Swedish experience with the Swedish female forest owner association "Spillkrakan". The Chairperson of Spillkrakan, Louise Uggla, gave a speech about the history and the aims of Spillkrakan, and 12 female forest owners attended. These women had inherited their forests from either their parents or their husbands.

In fact, most of the participants were glad to have an opportunity to talk about their views on forestry and forests, and they decided to stay in contact to continue exchanging views and organizing courses on the different aspects of forestry. As a result of this first meeting, the network was founded. The forest service supports this project as a service for their customers: forest owners (women as well as men).

\section{Status quo:}

The network is a loosely organized group of female forest owners who attend meetings and take active part in training courses and excursions. Since 2002, the network has organized training courses on the following topics:

- Forest inventory

- Taxes in forestry

- Forest Law

- Practical education in using a chainsaw 
- Timber trade/wood-market structures

- Forestry under special terms of complete public use (park management)

- Wood-selling contracts and wood-sale terms

- Visits to several modern sawmills

In general, about 20 to 25 women take part in these meetings and courses. The network is in need of financial funding in order to carry on the activities planned. It seeks governmental support.

\subsubsection{The Norwegian organization - Women in Forestry}

\section{By Berit Sanness}

The organization "Women in Forestry" was established 24 August 1986 at a gathering of female forester graduates and forestry students. The main objective of Women in Forestry is to motivate and stimulate women to participate and be involved at all levels of forestry; it emphasizes the importance of solidarity and cooperation among its members.

Women in Forestry chose a positive and constructive attitude as its strategy. The organization decided to propose actions and solutions to improve the gender balance within the sector, and its success depended on the acceptance among other women and men who were in decision-making positions within the forestry sector. Brandth, Follo and Haugen (2002) describe Women in Forestry as moderate, without a high feministic profile.

As the vision was to make the organization redundant in the future, the strategy focused on empowering women to approaching established organizations with their ideas and getting them to carry out the actions. From the very beginning, Women in Forestry achieved high-level support from the government and the private sector. A number of project initiatives were initiated by Women in Forestry and monitored, particularly during the first ten years of the organization. However, the achievements on gender balance are still far from satisfying, and a more active and aggressive strategy is needed for reaching a balanced and equitable workforce.

\section{Members and employees}

The organization welcomes all women interested in forestry to join, including students and forestry graduates, forest owners, daughters of forest owners, forest workers and women employed as secretaries or in other positions within the forestry sector. Even men and organizations supporting the organization's objective are welcomed as members. According to the annual reports, the highest number of personal memberships appeared in 1989, with 525 members (about 5 percent are men Jannicke Modell-Røhmen, personal information, 2006]). Currently the number of personal members is about 400, in addition to the 21 
organizations that are also members. To date, only women have been board members; however, several men representing organizations have been members of working groups and ad hoc groups.

Since 1988, one employee acts as secretary of the organization, but for the most part the work of the organization has been achieved by the members' voluntary work contribution.

\section{Key activities - new challenges}

From the beginning, women in Forestry sees the images of forestry as an obstacle to recruiting more women. Therefore, promotion of forestry education and the need for role models were high up on the agenda during the first ten years of Women in Forestry. In particular, the organization initiated several actions to motivate female forest owners. In addition, Women in Forestry highlighted the need for gender adjustments concerning practical forestry as well as focused on women as secretaries within the sector. Several initiatives included competence-building programmes. Since the mid-1990s, internal networking more or less became the organization's main task for a number of years.

Women in Forestry has recently decided that there is a need to take a closer look at the culture within forestry organizations and the conditions of the women employed as foresters within the forestry sector. There is a lack of updated documentation and analysis. However, several examples have shown a development that is worrying and the situation needs to be further studied. Recently, Women in Forestry also decided to introduce the need for quotas of women into positions within the private sector. This tool has not been on the organization's agenda before (Anne Katrine Løberg, personal information 2006). Actions carried out by Women in Forestry are further described in Annex VI.

\section{Women as key consumers}

Recently, women as key consumers have become a new task on the organization's agenda. The toolkit from the FAO/ECE Team of Specialists in Forestry and Forest Industry Sector (today named: the Forest Communicators Network) included clear recommendations concerning the forestry sector's need for improved communication with women in society. The recommendations were elaborated by a subgroup and based on the paper "Women as Key Consumers", by Berit Sanness. This paper highlighted women's impact on decisions concerning household consumption, their role as teachers and politicians, and the need for changes to have successful communication with women as target groups (Sanness, 1993). The Team's report recommended the forestry sector to (FAO/ECE 1995):

- study the plans and strategies of women's organizations; 
- choose the right information channels;

- choose the right words;

- choose the right pictures and speakers; and

- increase the share of female foresters.

While women make 80 percent of the decisions concerning the household (Gill, 2003, Sanness, 2003), the forestry sector is still not considering this. Therefore, since 2003 Women in Forestry has planned a test project dealing with women as key consumers. The objective is to develop methods to increase female consumers' trust in wood products and the management of forests in Norway. The test project will be carried out in cooperation with two forest owners' district organizations (Allskog BA and Viken Skog BA) during 2006.

\section{Summary and conclusions}

The Norwegian organization Women in Forestry was a pioneer when it was established twenty years ago. The vision was to make Women in Forestry redundant in the future. The organization chose a positive and constructive attitude, to ensure that everyone's energy could be used to the best for the future and initiated a number of projects and actions. As the achievements on gender balance within the Norwegian forestry sector are far from satisfying, a more active and aggressive strategy is likely to be on its way, including more focus on quotas. After ten years of mainly internal focus, the organization is once again about to become innovative and with external focus. 


\section{CRITERIA AND INDICATORS}

Since the Earth Summit on Environment and Development in 1992 in Rio de Janeiro, Brazil, sustainable development has become a new paradigm worldwide, and the importance of forests to sustainable development has been recognized. Since Rio de Janeiro, several international and national initiatives have been launched to improve the understanding of sustainable forest management (SFM) and to set up criteria and indicators to measure progress in sustainable forest management.

In North America and Europe, the most important processes are:

- The Montreal Process focusing on Temperate and boreal forests; and

- The Ministerial Conference on the Protection of forests in Europe (MCPFE).

And the certification schemes of:

- Pan-European Forest Certification; and

- the Forest Stewardship Council.

Montreal and MCPFE processes as well as the forest certification schemes of FSC and PEFC use criteria and indicators that provide a common definition of the characteristics of sustainable management of forests.

A criterion is a category of conditions, or processes, by which sustainable forest management may be assessed. A criterion is characterized by a set of related indicators that are monitored periodically to assess change.

An indicator is a measure (measurement) of an aspect of the criterion. A quantitative or qualitative variable which can be measured or described and which, when observed periodically, demonstrates trends.

Raising the question of gender-sensitive criteria and indicators, there are a number of organizations and processes that have defined criteria and indicators that are able to measure changes over time. One of these processes within FAO has led to "Gender Sensitive Indicators for Natural Resources Management". FAO notes that "gender sensitive indicators require the production of data that is disaggregated by sex, age, ethnicity and other socio-economic variables relevant to the project or programming context".

The mandate of the Team of Specialists on Gender and Forestry included the task "to develop criteria and indicators $(\mathrm{C} \& \mathrm{I})$ that would reflect gender aspects in sustainable forest management". The ToS discussed this issue of defining a new set of C\&I from the beginning, and because of this discussion, the ToS concluded not to add one more set of criteria and indicators to the already working processes and initiatives, but to recommend that FAO and member countries apply the FAO gender-sensitive indicators for natural resource 
management to forestry as well. Member countries and the above-mentioned certification bodies should be encouraged to broaden their scope of indicators in adding gender-sensitive indicators to the already established ones.

ToS holds firm that to mainstream gender in forestry implies that all member countries of Montreal and MCPFE processes, and the responsible decision bodies of certification schemes, take responsibility of further developing their own set of criteria and indicators, including measurable gender indicators.

To review the important sustainable forest management processes and initiatives identifying existing criteria and indicators affecting gender issues, ToS suggests performing a gender impact assessment to the existing C\&I schemes. This step should be done with gender expertise. 


\section{SUMMARY AND CONCLUSIONS}

Forests provide the source and means of survival for millions of people, who find there firewood, medicinal plants, food, fibres, housing materials, and a full range of other uses. They are also vital for the healthy state of our global environment. Many studies have shown that women are primary users of forests through their involvement in food production for subsistence, herb gathering or planting for medicine, fuelwood collection, and small-scale forest industries producing cash products. As well as often being the primary forest users, women are active and knowledgeable managers and caretakers of the forests.

This overview of gender and forest management and organization has shown that women have a complex relationship with forests and the forest sector. It is clear that although women are significant users of forest products, they rarely have input into forestry decision-making, either at the macro or even at the micro level. Even though some countries have introduced policy to improve the representation of women in the forestry sector, little has been done to encourage or follow up on this and thus the situation in most cases remains as it was before the legislation was passed. This is emphasized in the available statistics on the forestry sector labour force. Men dominate the forestry sector workforce in most countries and usually earn more than their equally qualified female counterparts.

Female representation within the forestry sector in some countries seems to be heavily influenced by the traditional values and perceptions of the role of women in society. Policies geared towards equal opportunities seem to have been impotent to break this general idea. Even when women hold the majority ownership of private forests, they are still marginalized in the decision-making process. One important lesson that may be learned from the case studies presented here is that there is no quick fix for increasing gender representation within the forestry sector. As this overview indicates, there are a myriad of issues that have to be dealt with first, which indirectly or directly influence the gender balance in the forestry sector.

This synopsis about gender and forestry has also highlighted the perceived differences in the relationship to, and the uses and methods of management of, natural resources among women and men. Women are credited with being more critical of forest management strategies, perhaps because they are more ecologically and socially aware of forestry issues. Women in forestry have been organizing themselves for more than 20 years. These networks, mainly of female forest owners have proved themselves as very useful and important forums for women to discuss common problems and provide information and support to each other.

A major constraint in compiling information on the three main aspects dealt with in this report was 
the paucity of information available. In many cases, where there was some data available these were from the government or public sector agencies. Very little information is available from the private sector and there are many aspects of gender relations in forestry that are still unexplored.

It's not all bad news! There are good examples where programmes designed to improve the involvement of women in the forestry sector have been working in several countries. These examples are not easily replicated because there are many enabling factors that must be addressed and these will vary from country to country. It is vital that governments recognize that gender relations influence many aspects of forest administration and control. Gender responsive forestry policies and programmes must explicitly take into account the needs, opinions and interests of men and women. These policies and programmes must be supported at all societal levels for their implementation to be successful.

\section{RECOMMENDATIONS}

The Team of Specialists believes that if there are to be any improvements in the current gender imbalance in the forestry sector in Europe and North America, these issues should be put on the agenda at all levels of the international community, government, private sector and public sector. The Team of Specialists further notes that in September 1995, at the United Nations Fourth World Conference on Women, "Governments ..... expressed their commitment to creating a new development paradigm that integrates environmental sustainability with gender equality and justice within and between generations as contained in chapter 24 of Agenda 21." However, since then, very little has been done to meet this commitment. In fact, and sadly so, many of the conclusions and recommendations from the 1995 United Nations conference in Beijing and those from the April 2001 Seminar on Women in Forestry still hold true today.

The Team of Specialists argues that the forestry sector can no longer afford to rely exclusively on the competence of a single gender, especially since:

- women make 80 percent of the decisions related to household consumption;

- in many countries there is a relatively high proportion of female forest owners;

- evidence exists which suggests that women are more sceptical of some of the concepts related to forestry and sustainable forest management. The information gleaned from the reasons why women may hold these views could be used to improve sustainable forest management practices and to improve communication strategies about these SFM practices; and

- evidence from other sectors indicates that gender-balanced organizations function more efficiently. 


\section{The Team of Specialists on Gender and Forestry therefore recommend that:}

1. The scope of rural development policies should be widened to encourage

- women to use the forest for income-generating activities to improve their livelihoods and that of the rural communities;

- the development of alternative livelihood opportunities;

- employers to recruit more women in rural areas; and

- a conducive workplace to enhance the retention rates of female employees.

2. Baselines and benchmarks should be established to measure changes in gender balance within the forestry sector

A baseline will provide a starting point from which to monitor and evaluate progress in the gender balance within the forestry sector. In the absence of this, it would be difficult to undertake any meaningful benchmarking against other industries, or within the forestry sector itself.

3. Member countries should increase the availability, access and use of gender statistics specifically for forestry. Gender disaggregated data must be included in national and industry statistics

The collection and analysis of gender-disaggregated data is extremely important if gender considerations are to be incorporated into programmes and policies. The availability of this information will make it possible to address the needs and priorities better of both men and women as well as for monitoring and evaluation of trends and changes.

4. Member countries should impress on the public and private sector the need to comply with existing legislation and to provide data in their annual reporting on the gender balance within their organizations

For any legislation to have an impact, it must be enforced. Effective administrative mechanisms must be put in place, to implement, monitor and evaluate progress of gender mainstreaming within the forestry sector.

5. International, governmental, non-governmental and research organizations must include the gender question in future surveys on all issues related to the forestry sector

Gender issues should be covered from the programme objectives to the respective action lines. Guidance should be given to identify potential gender impacts of the research areas and encourage researchers to conduct gender-sensitive research. 
6. Where appropriate, member countries should actively encourage the private and public sector to develop a quota system in pursuit of building a critical mass of women at the management level within the forestry sector

One way of mainstreaming gender in the forestry sector is by assigning quotas for the representation of men and women at the managerial level. The targets and the time frame for achieving these targets should be realistically set. Organizations dominated by men tend to be resistant to gender mainstreaming and to employing women in decision-making positions. It takes time to change attitudes of individuals and institutions and specific measures are needed in order to secure women's access to decision-making and leadership positions within the forestry sector.

The Team of Specialists proposes the following targets, where quotas are to be implemented:

- women should constitute 40 percent of the boards of forest companies and forest owners' organizations by 2015; and

- women should constitute 40 percent of the managerial level of forest companies and forest owners' organizations by 2015 .

7. An incentive scheme should be created to recognize companies and organizations that actively promote and deliver best practices related to gender issues

Incentives may be awarded for companies and organizations that have:

- increased the number of women in managerial/senior positions within companies;

- increased the number of women on the boards of the companies; and

- developed and implemented gender action plans.

8. Market tools, for example, certification (product, process and management) should be promoted as a means to increase the gender balance within the forest sector

9. A more positive and inclusive image of the forest sector and its work is promoted in the media

Programmes geared towards improving the image of the forestry sector as an attractive workplace should be developed and information disseminated to the public. Female role models could be used to encourage more women to become actively involved in the sector.

10. Governments should budget for gender-specific research within the forestry sector

Governments must demonstrate their commitment to this issue by allocating resources to mainstream gender issues into high-level research and policy analysis. 
11. Universities and colleges should include gender issues into their education programmes as the gender situation in a sector is to a large extent influenced by education.

In order to make progress in this respect including gender issues should be made a priority in accreditations of forestry study programmes.

12. The European Union promote collaboration among national/regional/international women networks and to assist in the establishment of new networks where necessary

The European Union must develop the mechanism to encourage collaboration among networks in the region. Women can learn from each other's experiences, share information and provide guidance to each other. This will provide them with the support they need to participate actively in forestry activities.

13. Member countries support the European Union in strengthening gender mainstreaming in its structural funds policies, including gender responsive budgeting

14. The Ministerial Conference on the Protection of Forests in Europe and other intergovernmental processes (Montreal Process, for example) review previous resolutions and criteria and indicators, and if necessary, highlight and include the gender issues in further commitments (Anregugen, 28 April 2006)

15. FAO and the ECE encourage member countries to revisit and address the recommendations made at the April 2001, Women in Forestry Seminar

16. Member countries produce national reports on gender and forestry and act on the recommendations and issues raised in the report 



\section{REFERENCES}

Asplund, G. 1986. Uran luominen. Miehet, naiset ja johtajuus. Kustannusosakeyhtiö Tammi. 209 s.

Augutaviciene, V. 1998. Women and forestry in Lithuania. Proceedings of Nordic-Baltic Workshop in Balsjö, Sweden. December 7-9, 1998. Pp. 76-77.

Berger, P. \& Luckmann, T. 1966. The social construction of reality. A treatise in the sociology of knowledge. London, Penguin Books.

Berlin, C., Lidestav, G. \& Holm, S. 2006. Swedish NIPF-owners' valuing of forest property benefits - differences between members in forest owner associations and non-members. Department of Forest Resource Management and Geomatics, Report 17. Umeå, Sweden, Swedish University of Agricultural Sciences.

Blombäck, P., Poschen, P. \& Lövgren, M. 2003. Employment trends and prospects in the European forest sector. Study prepared for the European Forest Sector Outlook Study (EFSOS), Geneva Timber and Forest Discussion Papers. Geneva.

Bock, M. 2004. Aktuelle Situation und Perspektiven der Waldarbeiterinnen in Deutschland.

Bojarski, M.J. 2005. Praktyka ochrony pracy kobiet na praykładzie Nadleśnictwa. SGGW. Warsaw. 85p. (MA thesis)

Borders Forest Trust Annual Review. 2004. Scotland.

Brandth, B. 1995. Rural masculinity in transition: gender images in tractor advertisement. Journal of Rural Studies, 11(2): 123-133.

Brandth, B. \& Haugen, M. 1998. Breaking into a masculine discourse. Women and farm forestry. Sociologia Ruralis, 38(3): 427-442.

Brandth, B., Follo, G. \& Haugen, M.S. 2002. Women in forestry: Gender processes and coping strategies. Paper No. 1/02, ISSN 0801-7263. Centre for Rural Research, Norway. 14 pp.

Brandth, B., Follo, G. \& Haugen, M. 2004. Women in forestry: Dilemmas of a separate women's organization. Scandinavian Journal of Forest Research, 19(5): 466-472.

Brandth, B. \& Haugen. M. 2004. From logger to tourist host. Changing rural masculinity. Paper presented at the XI World Congress of Rural Sociology. Trondheim, Norway.

Brunori, A. 2003. Informazioni analitiche sugli iscritti all'Ordine. Agronomi e forestali, No. 4-5.

Cappelli, M. 1991. Elementi di selvicoltura generale. Edizioni Edagricole. Bologna.

CE. 2000. Verso una strategia quadro comunitaria per la parità tra donne e uomini (2001-2005). Comunicazione della commissione al consiglio, al parlamento Europeo, al comitato economico e sociale e al comitato delle 
regioni. COM. 2000. 335 definitivo - 2000/0143 (CNS), 7 June 2000. Brussels.

Central Statistical Office. 2003. Labour force survey in Poland. Warsaw, Poland.

Confederation of European Forest Owners (CEPF). 2000. Confédération Européenne des Proporiétaires Forestiers/Confederation of European Forest owners/Zentralverband der Europäischen Waldbesitzer. Brochure. 48 pp.

\section{Confederation of European Forest (CEPF), Canadian Federation of Woodlot Owners (CFWO) and} American Tree Farm System (ATFS). 2002. Background discussion paper contributed by private forest owners. United Nations Forum on Forests, second session, March 2002. 11 pp.

Connell, R.W. 1995. Masculinities. Cambridge, Polity Press.

CENSIS. 1999. La professione del Dottore Agronomo e Dottore Forestale dall'azienda al territorio: quale identità, quale formazione, quale mercato. Rapporto finale reperibile al sito www.agronomi.it/docs/rapporto_censis.htm.

Colletti, L. 1998. La condizione femminile nel Corpo Forestale dello stato. Ministero delle Politiche Agricole e Forestali, Comitato pari opportunità.

Confederation of European Forest Owners. 2003. (Available at http://www.cepf-eu.org)

Dahl, E.A. 2006. Foresporsel om kevinneandel i Mjosen. Notat datert 15 Mars 2006.

Defrancesco, E. 1997. L'occupazione dei laureate in scienze agrarie e forestali dell'Università di Padova negli ultimi 10 anni. Agrinews, Marzo 1997, p. 1-3.

Di Gregorio D. \& Licari E. 2005. Il ruolo delle donne nell'agricoltura multifuñionale in Europa. Presentazione alla convegno nazionale: Donne della terra: i loro “numeri” per e nell'Agricoltura. ISTAT, Roma, 1 Gennaio 2005.

Direccao-Geral das Florestas. 2001. Proceedings from women in forestry seminar - Strategies to increase women's participation in the forestry sector in Europe and North America, Viseu, April 2001.

Ds 2004:39. 2004. Det går långsamt fram... Jämställdheten inom jord-och skogsbrukssektorn. Stockholm: Regeringskansliet.

Egeland, Å., Jacobsen, G.B., Kinderås, K., Ruderaas, A.B., Sanness, B. \& Strupstad, L.M. (Egeland et al.) 1983. Skogbruksjentene kaster barten. [The forestry women remove the moustache.] Norsk Skogbruk, No. 3.

Eriksson, O. 1987. Vurdering av laremiddelsituasjonen. Notat på vegne av Arbeidsgruppen for skoleverket, undergruppe fagskolene. Jenter i Skogbruket. Mo i Rana, April 1987.

Estonian Forestry. 2003. Ministry of Agriculture of Republic of Estonia. (Available at http://www.agri.ee/eng/) 
EUROSTAT. 2006. Harmonized Indices of Consumer Prices - March 2006.

EUROSTAT. 2004. Harmonized Indices of Consumer Prices - March 2004.

FAO. 2001. Global Forest Resources Assessment 2000. Main report forestry paper No. 140, Rome.

FAO. 2004. Forest finance trends and current status of the contribution of forestry sector to national economics. Working paper: FSFMA/ACC/07 FAO 2004.

FAO/ECE. 1995. Communications strategies in forestry and the forest industry sector (also known as the press and publicity “toolkit”), by FAO/ECE Team of PR Specialists in Forestry and the Forest Industry Sector.

FAO/ECE/ILO. 2001. Women in forestry - Strategies to increase women's participation in the forestry sector in Europe and North America. Proceedings of Seminar, 2-6 April 2001,Viseu, Portugal.

Flygare, I.A. 1999. Generation och kontinuitet. Familjejordbruket $i$ två svenske slättbygder under 1900-talet, (Generations and continuity. Family farming in two swedish grain-growing districts in the $20^{\text {th }}$ century). Uppsala: Upplands Fornminnesförenings Tidskrift 54, Upplands Fornminnesförenings Förlag. (Dissertation in Swedish with an English summary)

Furuberg, M. 2006. Regional partnership for forestry and equality. Gender and forestry in Hedmark County, Norway. Paper, 25 March, 2006.

Giglioli A., \& Harald M. 1999. Pericolo mobbing. Osservatorio nazionale UIL sul mobbing.

Gill, E. 2003. Forbrukernes holdninger til skogbruket og skogindustriens produkter. Sammenstilling av kvantitative og kvalitative undersøkelser blant britiske, tyske, hollandske og norske forbrukere, 1995-1999. Utgitt av Norges Skogeierforbund, Oslo.

Giungi M., \& Zanzi Sulli, A. 1993. Le lavoratrici forestali e boschive nei censimenti della popolazione dall'unità d'Italia a oggi.

Government of Latvia. 2003. Forest sector in Latvia. Ministry of Agriculture, Republic of Latvia. 31 pp.

Government of Lithuania. 2004. Forests of Lithuania. Ministry of Environment, Republic of Lithuania.

Government of Lithuania. 2004. Lithuanian statistical yearbook of forestry. Ministry of the Environment of Republic of Lithuania. 112 pp.

Griffen, V. 2001. Seeing the forest for the people, A handbook on gender, forestry and rural livelihoods. Asian and Pacific Development Centre. Kuala Lumpur, Malaysia.

Gutek, B.A. 1985. Sex and the workplace. San Francisco, Jossey-Bass Publishers.

Hagen, I.K. 2006. Kvinnelige skogbrukere. Dokument fra førstesekretær Inger Karin Hagen, Høgskolen i Hedmark, datert 24-3-2006. 
Hankala, T. 1998. Naismetsänhoitajien palkat lähes 10\% pienempiä kuin miehillä yksityisellä sektorilla. Metsänhoitaja 2/1998. s. 24-25.

Haugen, M.S. 1994. Rural women's status in family property laws: Lessons from Norway. In S. Whatmore, P. Marsden \& P. Love, eds. Gender and rurality. Critical perspectives on rural change series VI, pp. 87-101. David Fulton Publishers, London.

Haugen, M. 2005. WITAS - kvinner i fokus. Finnskogtoppen 8-9 April 2005. Prosjektrapport utarbeidet av Mari Haugen, Glommen Skogeierforening.

Heggertveit, C.Q. 2006. Skogfagutdanningen i Norge 2006. Foredrag av studieveileder Christina Qvam Heggertveit, Universitetet for Miljø og Biovitenskap, under Jenter i Skogbrukets fylkeskontaktsamling den 4 Februar 2006.

Hoffmann, V. 1998a. Beschäftigung von Frauen in der Waldarbeit in Geschichte und Gegenwart.

Waldarbeiterinnen in Deutschland - Pflanzfrauen oder Forstwirtinnen. Allgem. Forstz. 53, 26, 1580-1582.

Hoffmann, V. 1998b. Die Arbeitssituation der Waldarbeiterinnen in Deutschland. Eine sozialempirische Untersuchung unter besonderer Berücksichtigung der Arbeitsbeanspruchung. [Working situation of female forest workers: a socioempiric study with special regard of working strain]. Hamburg: Kovac. Schriftenreihe agrarwiss. Forschungsergebn. 14.

Höjer, M.W. \& Åse, C. 1996. Politikens paradoxer. En introduktion till feministisk politisk teori. Lund: Academia Adacta.

Huse, K. 2006. Kvinneandel i organisasjoner - SKI. Dokument fra administrerende direktør Knut Huse, Skogbrukets Kursinstitutt, datert 14-03-2006.

Ihalainen, R. 1987. Nainen metsänhoitajana. Folia Forestalia 698. Metsäntutkimuslaitos. 32 s.

ISTAT. Censimento Generale dell'Agricoltura. Anni vari.

ISTAT. 1998. Struttura e produzione delle aziende agricole a conduzione femminile. ISTAT, Statistiche in breve.

ISTAT. 2002. $14^{\circ}$ Censimento della Popolazione.

ISTAT. 2003. $1^{\circ}$ Censimento No-profit.

Jämställdhet vid Fakulteten för Skogsvetenskap. 2005. Report from Jämställdhetsutskottet to the Faculty, 01-12-2005.

Kaipainen, J. 1998. Naiset metsäammattilaisina. Teoksessa: Ripatti, P. (toim.) 1998. Naiset metsäsektorilla. Metsäntutkimuslaitoksen tiedonantoja 697. s. 39-53.

Kanter, R.M. 1977. Men and women of the corporation. New York, Basic Books, Inc. Publishers. 
Kärkkäinen, S. ja Toivanen, E. 1995. Uudistusalalla, naismetsänhoitajien elämää vuodesta 1918. Painorauma Oy. 134 s.

Köpf, E.U. 1999. Privatwaldforschung in den ostdeutschen Bundesländern. Ein Sachstandsbericht. Allgem. Forstz. 54, 21, 1122-1125.

Korvajärvi, P. 1996. Sukupuoli työpaikalla. Teoksessa: Kinnunen, M. ja Korvajärvi, P. Työelämän sukupuolistavat käytännöt. s. 89-108.

Kostarczyk, E. 2005. Kobiety nauki w polskich gremiach decydenckich. (Available at www.wp.pl)

Kveli, J. 2006. Skogbruksstudenter som har fullfort fra 1988 til 2002 (opptaksår). Dokument fra studieveileder Jens Kveli, Høgskolen i Nord-Trøndelag, datert 27-03-2006.

Kwiatkowski, E., Socha, M., \& Sztanderska, U. 2001. Labour market flexibility and employment security Poland. International Labour Organization, Geneva, Switzerland.

Lidestav, G. \& Wästerlund, D. 1998. Skogsutbildade kvinnor och mäns villkor i arbetslivet - resultat från en enkätundersökning. (Arbetsdokument 4). Umeå: Sveriges lantbruksuniversitet, Institutionen för skogsteknik, Umeå.

Lidestav, G. \& Sjölander, A. 2005. Gender and forestry - A critical discourse analysis of forestry professions in Sweden. Paper presented at Knock on Wood IUFRO 6.18.01 Pre-Congress Meeting. August 4-7 200, O’Really's, Lamington National Park, Australia.

Lewark, S., Pettenella D., \& Saastmoinen O. 2000. Il mercato del lavoro per i laureati forestali nell'Unione Europea. Sherwood 55, pp. 33-39; Shervood 56, pp. 29-34.

Lewark, S. 2004. Ways and examples of implementing gender issues into forestry curricula. In C.C. Konijnendijk, J. Schipperijn, \& K.K. Hoyer. Forestry serving urbanised societies. Proceedings of the IUFRO European Regional Conference, organized in cooperation with EFI, Copenhagen, 27-30 August 2002. IUFRO World Series No. 14, IUFRO, Vienna, pp. 391-399. (Available at http://www.iufro.org/ publications/series/world-series/worldseries-14)

Lewark, S. 2003. Kulturfrauen und Maschinenführer - von der Arbeitsteilung in der Forstwirtschaft. Freiburger FrauenStudien 13, Vol II, 235-268.

Lidestav, G. 2003. I konkurrens med en bror. Könsrelaterade överlàtelsemönster inom det samtida svenska familjeskogsbruket. Working paper 183. Department of Silviculture, Swedish University of Agricultural Sciences, Umeå.

Lidestav, G. \& Nordfjell, T. 2005. A Conceptual Model for understanding Social Practices in Family 
Forestry. Small-scale Forest Economics Management and Policy, 4: 391 -408.

Lindstad, B.H. 1995. Forglem meg ei. Prosjektrapport fra "Flere kvinner i skogbruket", Skogbrukets Kursinstitutt 1992-1995.

Lyren, L. 2003. Gender and Forestry - a bibliography, Umea. Working paper 189. Department of Silviculture, Swedish University of Agricultural Sciences.

Magnusson, E. 1998. Vardagens könsinnebörder under förhandling: om arbete, familj och produktion av kvinnlighet. Umeå: Umeå universitet.

Mizaraite, D. 1999. Women as Private Forest Owners. Proceedings of symposium on "Women and Forestry”, 12-15 August 1999, Lillehammer, Norway. Pp. 76-82.

Mizaraite, D. 2001. Objectives, problems and needs of the private forest owners as well as dependence on various factors. Miskininkyste. T. 1(49): 33-46. (In Lithuanian)

Niskanen, K. 2001. Husbondeväldets röst. Äktenskap, egendom och kön under första delen av 1900-talet. Pp 131 -158. In Liljewall, Niskanen \& Sjöberg, eds. Kvinnor och jord. Arbete och ägande fränmedeltid till nutid. Skrifter om skogs-och lantbrukhistoria nr 15. Nordiska museets förlag. Lund.

Nordic Council of Ministers. 1994. Women and men in the Nordic countries. Nord 1994:3. Copenhagen, Denmark.

Norwegian Forest Owners' Federation. 1986, 1991, 1996, 2001, 2005. Adresse-og Telefonbok for Skogeierorganisasjonen.

Norwegian Forest Owners' Federation. 1992. En eller to stemmerpr. bruk. Brev til skogeierforeningene 2.10.92.

Norwegian Forest Owners' Federation. 2005. Normalvedtekter for skogeierlag tilknyttet skogeierandelslag BA. Vedtatt på Skogeierforbundets styremøte 7 Juni 2005.

Norwegian Forest Owners' Federation. 2006. Annual report 2005.

Norwegian Forest Research Institute. 2005. Utdrag av Skogforsks innspill til statsbudsjettet for 2006.

Norwegian Forestry Society. 1986, 1996, 2001, 2005, 2006. Nokkelen til skogbruket og skogindustrien 19861987. Utgitt av Det norske Skogselskap. 12. utgave ...29. utgave.

Norwegian Ministry of Agriculture. 1992. Landbruk i utvikling. St.prp. nr. 8, 1992-93.

Norwegian Ministry of Children and Family Affairs. 2005. Press release No 05116. Date: 8 Dec, 2005 Norwegian Statistics. 2004. Landbruksundersokinga 2004.

NoU. 1991. Norsk landbrukspolitikk.Utforming, mål og virkemidler. 
Nowacka, W. L. 2001. Qualified women in Polish forestry sector. The past and the present of the university level education. Proceedings of Joint FAO/ECE/ILO Committee on Forest Technology, Management and Training, Seminar Proceedings: Women in forestry - strategies to increase women's participation in the forestry sector in Europe and North America, 2-6 April 2001, Viseu, Portugal. 338-339 pp.

Nowacka, W. L. 2004a. Uses of forests by female inhabitants of nearby small towns. Gender and forestry: Challenges to sustainable livelihoods and forestry management. The Second World Wide Symposium on Gender and Forestry, 1-10 August 2004, Kilimanjaro, Tanzania. (Poster prepared and presented during symposium - in publication.)

Nowacka, W. L. 2004b. Wpływ techniki pracy na obciążenie fizyczne przy pieleniu ręcznym w szkółce leśnej. Materiały III Seminarium: Bezpieczeństwo pracy w nowoczesnym leśnictwie. Tuchola 29 czerwca 2004r. Tom III, pp. 40-49. Wydawnictwo: Katedra Inżynierii Środowiska Pracy AR Poznań, Państwowa Inspekcja Pracy- OIP Poznań, Międzynarodowe Targi Bydgoskie „SAWO” Sp. Z o.o. , Poznań 2004r.

Nowacka, W. Ł. 2005. Kobiety w leśnictwie-stare problemy, nowe spojrzenie. Głos Lasu, nr 1, pp. 42-45.

Nowacka, W. L., Moskalik T., Paschalis P. \& Zastocki D. 2006. Implementation and socio-economic impact of mechanization in France and Poland - the Polish experience. (In publication)

Øyangen, G. 1987. Foredrag av landbruksminister. Gunhild Øyangen under årsmøtet til Jenter i Skogbruket, Hurdal 5 September 1987.

Rametsteiner, E. \& Kraxner, F. 2003. Europeans and their forests. What do Europeans think about forest and sustainable forest management? Ministerial Conference on Protection of Forests in Europe, Vienna, Austria.

Ringsell, A. 2000. Job satisfaction among county forest rangers and company forest supervisors - a comparison between occupation and gender. Forest Technology, Swedish University of Agricultural Sciences, Umeå. (Student’s report 35)

Reed, M.G. 2003. Marginality and gender at work in forestry communities of British Columbia, Canada. Journal of rural studies 19, pp. 373-389.

Sanness, B. 1992. JiS - en sovepute for skogbruket? Leders tale til årsmøtet i Jenter i Skogbruket, Mysen, 24. Oktober 1992.

Sanness, B. 1993. Women as key consumers. Paper at the annual meeting of the FAO/ECE

Sanness, B. 2003. Fokus på skog og miljo. Markedsaktorenes innflytelse på forvaltningen av skogressursene på 90-tallet. Published by the Norwegian Forest Owners' Federation Oslo.

Sawyer, B. 2003. Fromheten, familjen och förmögenheten. In Hans och Hennes. Genus och egendom i Sverige från 
vikingatid till nutid. Pp. 37-59. Ågren. M. (ed). Uppsala: Opuscula. Historica Upsaliensia 30.

Schmaltz, S. 2004. Careers of Education and Employment of Female Forest Engineers graduated from the Department of Forestry and Environmental Management of the University for Applied Science and Arts Hildesheim/Holzminden/Göttingen. In C.C. Konijnendijk, J. Schipperijn, \& K.K. Hoyer, 2004: Forestry serving urbanised societies. Proceedings of the IUFRO European Regional Conference, organized in cooperation with EFI, Copenhagen, 27-30 August 2002. IUFRO World Series No. 14, IUFRO, Vienna, pp. 401-406. (Available at http://www.iufro.org/publications/series/world-series/worldseries-14)

Schriewer, K. 1995. Waldarbeiter in Hessen - Kulturwissenschaftliche Analyse eines Berufsstandes. Hamburg:Arbeitskreis Volkskunde und Kulturwissenschaften (Marburg), Reihe Lebens- und Staatsformen (Band 2).

Sjåvik, K. 2006. Rapport fra Kintetten. Dokument pr. e-mail 24.03.06 av styremedlem Kåre Sjåvik, Allskog BA.

SFPF. 2003. The working life study 2003 of the Society of Finnish Professional Foresters.

Statistical Yearbook of Forestry. 2004. Official Statistics of Sweden, National Board of Forestry. Jönköping, Sweden.

Statistical Yearbook of Forestry. 2005. Official Statistics of Sweden, National Board of Forestry. Jönköping, Sweden.

Statistics Sweden. 1994. Skogsdataregistret. The Forestry computer file. Unpublished work material.

Steinkamp, C.B. 1983. Waldwirtschaft auf kleinen Flächen im Urteil der Waldbesitzer und Forstleute. Freiburg, Univ., Forstl. Dissertation, 240 S. + Anh.

Strøm, R. 2006. Statskog SF 1993-2006. E-mail from Rannveig Strøm, Statskog SF. Namsos, 22 February 2006.

Strupstad, L.M. 1991. Den tause skogeier. En analyse av kvinnelige skogeieres aktivitetsnivå og deltakelse i skogbruket. Rapport nr. 43. Telemarksforskning, Bø.

Suutari, M. 2003. Korkeakoulutettujen työelämäurien alkuvuodet. LAASER-projektin loppuraportti. Akava. 89 s. + liitteet.

TBFRA. 2000. Forest Resources of Europe, CIS, North America, Australia, Japan and New Zealand. UN-ECE/FAO Contribution to the Global Forest Resource Assessment 2000. Main Report. ECE/TIM/SP/17. ISBN 92-1-116735-3.

Thernborn, G. 1995. European modernity and beyond. Sage, London.

Tomlin, P. 2003. Professional women foresters in the British forestry industry. The Forestry Commission, Edinburgh, Scotland. 
Turunen, K. 2002. Metsäalan korkeakoulutuksen määrällinen ja laadullinen ennakointi, hankkeen loppuraportti ja osatutkimusraportit. Metsänhoitajaliitto ry.

Viilma, K. 1998. Women and forestry in Estonia. Proceedings of Nordic-Baltic workshop, December 7-9, 1998, Balsjö, Sweden. Pp. 70-74.

Vilkriste, L. 1998. Women and forestry in Latvia. Proceedings of Nordic-Baltic Workshop, December 7-9, 1998, Balsjö. Sweden. P. 75-76.

Vilkriste, L. \& Konstantinova, I. 1999. Women in Latvia forestry: Starting points for research. Proceedings of symposium on "Women and Forestry", 12-15 August 1999, Lillehammer, Norway. Pp. 47-51.

Vinnecombe, S., et al. 1999. Making it to the top in Britain. Research paper for Cranfield School of Management, Cranfield University, United Kingdom.

Wahl, A., Holgersson, C., Höök, P. \& Linghag, S. 2001. Det ordnar sig. Teorier om organisation och kön. Lund: Studentlitteratur.

Wahl, A. 2003. Könsstrukturer i organisationer. Lund: Studentlitteratur.

Westermayer, T. 2006. Zur Zahl der in der Forstwirtschaft und Forstverwaltung in Deutschland arbeitenden Frauen und Männer(Number of men and women working in Germany's Forest service). Freiburg: Unpubl.manuscript from research "project wa-gen".

http: //www.shell.com /home / Framework?siteId=de-de\&FC2= /de-de /html /iwgen /about_shell /Jugendstudie /2002 /zzz_lhn.html\&FC3=/de-de /html /iwgen /about_shell /Jugendstudie / 2002 / jugendstudie 2002_14jspresseinfolang.html (30 April 2006).

Whitcomb, K. Feldman, D. 2005. The effects of framing vocational choices on young adult's sets of career options. Career Development International, Vol. 10, 1, pp. 7-25.

Winther Jørgensen, M. \& Philips, L. 1999. Diskurs analyse som teori och metod. Frederiksberg: Roskilde Universitetsforlag/Samfundslitteratur.

Women in Forestry. 1997. Prosjektet Kvinnelige kontoransatte. Et prosjekt i samarbeid mellom Landbruksdepartementet, Jenter i Skogbruket og Norges Skogeierforbund, 1993-1997. Prosjektrapport.

\section{Women in Latvian Forestry. Brochure.}

Women in Lithuanian Forestry. (Available at http://www.forest.lt; in Lithuanian)

Zubkowicz, R. 2005. Lubię rządzić. Las Polski , Nr 18, pp. 12-14. 



\section{ANNEXES}

\section{LIST OF ACRONYMS AND DEFINITIONS:}

ASAU: Armenian State Agrarian University

C\&I: Criteria and indicator

CIS: Commonwealth of Independent States

CEPF: Confederation of European Forest Owners

CFS: State Forestry Corp

CLF: Civilian Labor Force

ECE: Economic Commission on Europe

EEOC: Equal Employment Opportunity Commission

EU: European Union

FAO: Food and Agriculture Organization of the United Nations

FOAL: Forest Owners Association of Lithuania

GUS: Central Statistical Office

ICF: Institute of Chartered Foresters

ILO: International Labour Organization, United Nations Organization based in Geneva, Switzerland

IUFRO: International Union of Forest Research Organisations

MCPFE: Ministerial Conference on the Protection of Forests in Europe

NRCan: Natural Resources Canada

NGO: Non-governmental organization

ONS: Office of National Statistics

SFPF: Society of Finnish Professional Foresters

SFM: Sustainable forest management

SME: Small and medium sized enterprises

TBFRA: Temperate and Boreal Forest Resources Assessment

ToS: Team of Specialists

UCAS: University Admissions and Clearing House

UN: United Nations 


\section{LIST OF TABLES}

Table 1: $\quad$ FAO/ECE/ILO Team of Specialists Attendance at Meetings on Gender and Forestry

Table 2: Model for analyzing gender situation and structures in forest organizations at the national level.

Table 3: Composition of women in Armenian forest enterprises

Table 4: Representation of women in the workforce at four forestry agencies

Table 5. Student distribution in forestry courses at ASAU (2002/2003 academic year)

Table 6: Female representation by occupational category for NRCan

Table 7: Female representation by occupational category for the Canadian Forest Service

Table 8: Percentage of female and male employees in the forest industries

Table 9: $\quad$ Percentage of all employees in management positions and positions requiring skill level A in forest industries for 2001, by sex

Table 10: Percentage of females with academic qualifications in the forestry field, by age

Table 11: Employment activity of individuals with academic qualifications in forestry fields for all ages (2001)

Table 12: Proportion of women at the Faculty of Forestry, the Forest Research Institute, Jastrebarsko, and the State Enterprise "Croatian Forests", Inc.

Table 13: Opinions of Croatian women foresters regarding professional development

Table 14: Gender disaggregated data from state forest services from five exemplary states, 2002

Table 15: Number of students and proportion of women in the four universities with forestry study programs in Germany

Table 16: Women employed, by occupation, by CFS (1996-1997)

Table 17: Women graduates at Italian universities (Bachelor of Science or Master of Science degrees in forestry)

Table 18: Self-employed graduates in agriculture and forestry, by age and gender (2003)

Table 19: Self-employed graduates in agriculture and forestry, by geographical distribution and gender (2003)

Table 20: Forestry graduates employed three years after graduating, by gender and type of job (permanent or temporary)

Table 21: Changes in employment for graduates in Forestry Sciences, University of Padova 
Table 22: Forestry workers employed by public forestry authorities, by gender

Table 23: Public officials and managers employed by public forestry authorities, by gender

Table 24: Share of women in forestry positions in the Norwegian Forestry Service, 1986-2006

Table 25: Women students and graduates from the Faculties of Forestry at Agricultural Universities in Krakow, Poznan and Warsaw, 1985-1999

Table 26: Means of typical forest uses by women in local communities

Table 27: Employment indicator by gender (\%), in 1994-2003

Table 28: Number of women graduates at the Forestry Faculty, 1947-2000

Table 29: Gender representation

Table 30: Women by positions within the state forest enterprise - Lesy SR, district of Banská Bystrica - 2006

Table 31: University applications by gender (2000-2003)

Table 32: Ownership structure in the ECE area

Table 33: Proportion of female forest owners in different ownership categories (\%)

Table 34: Proportion of male and female owners on forest properties acquired via their own parents/relatives by ownership constellation $(n=980)$

Table 35: Descriptive accounts of owners and forest estates acquired via parents or relatives

Table 36: Comparison of male and female forest owners regarding general ownership features and variables with relevance on gender, inheritance and management

Table 37: Forest owners' valuation of different goods and land for nature conservation, by mean value $(1=$ No relevance, $5=$ very important $)$

Table 38: Women's representation in forest owner association boards and district boards, 2006

Table 39: Share of women on the board of directors, district associations, 1986-2005

Table 40: Share of women as board members of local forest owners' associations, 1986-2005

Table 41: The share of women employees at district level in forest owners' organizations (1986-2005)

Table 42: The European Community Framework Strategy on Gender Equality

Table 43: Numbers of courses including gender issues named, by country

Table 44: Matrix for discussing topics 


\section{LIST OF FIGURES}

Figure 1: Finnish foresters' gender structure by age groups (2004)

Figure 2: Differences in salaries between genders in 1996

Figure 3: Employees within the primary sector in Italy, by gender (\%)

Figure 4: Employees in the forestry sector ( $\%$ on the total number of employees in the primary sector)

Figure 5: Women employed in forestry (\% on the total number of employees in the forestry sector)

Figure 6: Men and women employed by the CFS (1997)

Figure 7: Number of forestry students at the University of Agriculture (1985-2005)

Figure 8: Women in management positions at State Forests: Directorate General of the State Forest

Figure 9: Employment in State Forest Districts in 1990-2003

Figure 10: Women employed in the State Forest Districts in 1990-2003

Figure 11: Women in the U.S. Forest Service and Civilian Labor Force (CLF)

Figure 12: Professional Female Foresters in the U.S. Forest Service and CLF

Figure 13: Professional Female Wildlife Biologists in the U.S. Forest Service and CLF

Figure 14: Professional Female Archaeologists in the U.S. Forest Service and CLF

Figure 15: Professional Female Hydrologists in the U.S. Forest Service and CLF

Figure 16: Number courses, including gender issues implicitly or explicitly

Figure 17: Courses including gender issues according to compulsory or electives

Figure 18: Proportion of women among students, researchers, and professors at the University of Freiburg (winter semester 2000/2001)

Figure 19: Characteristics of the first gender study course at the University of Freiburg, winter 1999/2000 


\section{LIST OF TOS MEMBERS}

Ms. Liz Agpaoa

Washington Office, USDA/Forest Service

Tel: +1 2022050998

Fax: +1 2023584063

Email: lagpaoa@fs.fed.us

Ms. Skaidrite Albertina

Forest Owners' Association of Latvia

Rigas Street 113 Salaspils LV-2169 Latvia

Tel: +371 7949647

Fax: +371 7980056

E-mail:pfefs@parks.lv

Ms. Merete Furuberg

Department of Forestry and Wildlife Management

Hedmark University College

Evenstad 2480 Koppang Norway

Tel: +4790163092

Fax: +4762945753

E-mail: merete.furuberg@hedmark-f.kommune.no

Ms. Natalie Hufnagl

CEPF Rue de Luxembourg 47-51

1050 Bruxelles Belgium

Tel: +32 22190231

Fax: +3222192191

E-mail: hufnagl@cepf-eu.org

Ms. Marion Karmann

Combahnstrasse 81

53225 Bonn Germany

Tel: +49228367 6611

Fax: +492283676630

E-mail: mkarmann@web.de

Ms. Bozena Kornatowska

MCPFE Liaison Unit Warsaw

ul. Bitwy Warszawskiej 1920 r. nr 3

00-973 Warsaw, Poland

Tel: +48 223317031

Fax: +48223317032

mailto: b.kornatowska@lu-warsaw.pl

Mr. Siegfried Lewark

Institute for Forest Utilization and Work Science

University of Freiburg

Werderring 679085 Freiburg Germany

Tel: +49 7612033764

Fax: +497612033763

E-mail: siegfried.lewark@fobawi.uni-freiburg.de

\section{Ms. Gun Lidestav}

Swedish University of Agricultural Sciences (SLU)

Division of Forest Technology

Dept. of Silviculture

90183 Umeå Sweden

Tel: +46-90 7866811

Fax: +46-90 7867669

E-mail: gun.lidestav@ssko.slu.se
Ms. Wieslawa Nowacka

Warsaw Agricultural University

Nowoursynowska159 02-776 Warsaw, Poland

Tel: +48225938133

E-mail: Wieslawa.Nowacka@wl.sggw.pl

Ms. Berit Sanness

The Norwegian Forest Owners' Federation

P.O. Box 1438 Vika 0115 Oslo Norway

Tel: +4722010550

Fax: +4722834047

E-mail: berit.sanness@pinus-betula.no

Ms. Renate Spaeth

Ministry for Environmental and Nature Conservation

Agriculture and Consumer Protection

Schwannstr. 340476 Düsseldorf, Germany

Tel: +49 2114566276

Fax: +49 2114566947

E-mail: renate.spaeth@munlv.nrw.de

Ms. Simmone Rose

FAO, Forestry Products and Economics Division

Viale delle Terme di Caracalla 00100 Roma Italy

Tel: +39-06 57053242

Fax: +39-06 57055137

E-mail: simmone.rose@fao.org

Ms. Patricia Tomlin

Wildcat One Ltd

Pentlandfield Roslin EH25 9RE, UK

Tel: +441314403222

Fax: +441312211

E-mail:pat@wildcat-one.com

Ms. Gunilla Törnquist-Hedström

The Swedish Women Forest Owners Association - Black

Woodpecker

Norra Hamnvägen $20 \mathrm{~A}$

11541 Stockholm Sweden

Tel: +4687829997

gunilla.hedstrom@telia.com

\section{Mr. Eriks Zakis}

Forest Owners' Association of Latvia

Rigas Street 113 Salaspils LV-2169 Latvia

Tel: +371 7949647

Fax: +371 7980056

E-mail: zakis.maa@delfi.lv 


\section{NORWAY: POLITICAL TOOLS}

Author Berit Sanness

\section{Actions}

The Norwegian Ministry of Agriculture took a number of actions in order to achieve a better gender balance within the forestry sector since the issue was put on the political agenda in 1986. In particular, they took place in the late 1980s and early 1990s. Among the actions were:

- An information campaign concerning the change in the the act regulating who would have the right to become the next farmer/forest owner by heritage. The campaign provided information to women about their new rights to heritage farms/forests. It was developed and run mainly during the late 1980s.

- Information campaigns to increase the share of women in forestry schools, and studies, were developed and implemented. In particular, actions took place during the late 1980s and early 1990s, in close cooperation with Women in Forestry.

- Political and economical support to women in agriculture and forestry, which was specified in the national budget (1986-1987). From the late 1980s to the end of the 1990s, consultants on gender matters were employed at the government's Department of Agriculture and Forestry at the county level.

- Political and economical support to the organization Women in Forestry since the launching in 1986. Economic support specified in the national budget was approved by the Parliament from 1989 until 2002.

- The mandate of the Committee on Agriculture and Forestry Policy (1987-1990) appointed by the Cabinet, included gender policy.

- Developed and ran a new extension programme for young women who needed practical experience within forestry to be able to apply for forestry education at the university or the university colleges (developed and promoted in cooperation with Women in Forestry). Actions executed in the late 1980s and early 1990s (after some time this was extended to both sexes and in the agriculture sector).

- Supported a project (1993-1995) to give secretaries within the forestry sector more competence on forestry matters (initiated by Women in Forestry).

- Supported a project (1992-1995) to develop extension courses to better meet the needs of female 
forest owners. Initiated by Women in Forestry - developed by the Norwegian Forest Extension Institute.

- A research programme (1987-1992) on "Women in the agriculture and forestry sector" included a project on female forest owners.

- Supported the first international symposium on "Women and forestry" at Lillehammer, 1999, providing a platform for following up on actions and priorities of gender actions made within IUFRO,

- At present, supporting a doctoral study on female forest owners at the Norwegian Centre for Rural Research.

\section{Laws and regulations}

While some of the laws and regulations concerning gender balance are similar to those in other countries, others are unique. The laws concerning gender balance in Norway are:

- In 1959, Norway ratified the ILO-convention on Discrimination (C111) from 1958.

- In 1974, the Act regulating who would become the next farmer/forest owner after the parents was changed. Until then, the eldest son had the best right. The change forced the firstborn child, regardless of sex, to get the best right for acquiring property. This law was decided by Parliament in 1974, and came into effect for children born after 1 January 1965.

- The Gender Equality Act from 1978 (with later amendments) has the aim to improve the equal rights between the sexes and in particular to improve women's position. According to the act, all levels of government are obliged to implement active, goal- oriented action plans to achieve equal rights between the sexes, in all parts of society. In addition, the act states that employers and their organizations are obliged to do the same.

- In 1981, Norway ratified the 1979 United Nations Convention of the Elimination of All Forms of Discrimination against Women. The convention is to be followed as an act in Norway.

- Since 1981, the Gender Equality Act has included a new section on gender representation rules, demanding that each sex shall be represented by at least 40 percent in all public committees, councils, boards, etc., appointed by a public body.

- In 1991, the Act concerning common forests ("Allmenningene") was changed to include the option of two votes per farmer; however, it depended on both of them being present at the elections. The aim was to increase women's participation. 
- Since 2002, businesses, according to Norwegian laws, are obliged to present annual reports, and shall report on the actual position concerning equal rights within the company or organization. It should also report the actions that have taken place and the actions that are planned to improve equal rights and prevent discrimination, as required by the Gender Equality Act.

- The Act of 19 December 2003 on 40 percent gender representation on company boards was passed with a broad majority in the Norwegian Parliament. The Act was meant to secure men and women equal opportunities for representation on company boards, in accordance with the principle of equal treatment. The private sector was given two years to show that the requirements of the act would be met on a voluntary basis, without the law being enforced.

- After 1 January 2004, state-owned companies need to meet the demand that each sex shall be represented by at least 40 percent on the board of directors.

- In 2005, the government distributed a draft set of regulations (similar to those for public limited companies) concerning gender balance on the boards of cooperatives (for instance, forest owners' organizations) for comments by organizations. At present, the comments are under consideration from the government.

- After 1 January 2006, public limited companies need to meet the demand that each sex shall be represented by at least 40 percent on the board of directors. Even if progress was made, the government decided that the results were not sufficient and the Act of 19 December 2003 was enforced (the Ministry of Children and Family Affairs, 2005). 


\section{NORWAY: ACTIONS CARRIED OUT BY WOMEN IN FORESTRY}

By Berit Sanness and Pinus-Betula AS (Norway)

\section{Introduction}

The organization "Women in Forestry" was established 24 August 1986. The women foresters in Norway:

- found it more rational to create a new organization rather than try to change the old ones;

- $\quad$ realized the need for a network among them;

- $\quad$ saw the need for role models if more young women were to become foresters;

- realized the need for establishing a contact address; and

- decided to welcome all women interested in forestry to join the new organization.

The Norwegian women concluded that it was hard to be a woman on their own within the forestry sector, as it was the most masculine sector in Norwegian society. By networking women could exchange experience and motivate each other. Women in Forestry was launched with a vision to make itself redundant in the future; however, the organization still exists as the mission is not yet completed.

\section{Promotion of forestry education - role models}

During the initial years, Women in Forestry gave high priority to promoting forestry education as an option for young women. The aim was to broaden the picture of what an education within forestry was, the opportunities it offered, and how forestry education would suit women as well as men. Actions particularly during the late 1980s and early 1990s included production of overheads, exhibitions and other material promoting women and forestry, as well as the presence of a high number of exhibitions targeting young women and teachers.

Substantial work was done by the organization and its members to assist the forestry sector in the promotion of the sector. For some years, a positive effect on the gender balance within the forestry education system was recognized. However, the number of female students has fallen dramatically lately, as well as the number of forestry students as a whole. Currently, the Norwegian forestry sector offers few positions for forestry graduates.

From the very beginning, Women in Forestry saw the image of forestry as an obstacle to recruiting more women. During the first years, the organization received much exposure in the media. This gave many opportunities to present role models. One of the first studies initiated by Women in Forestry was an evaluation of how forestry books and materials communicate with women and their positions within the forestry sector. 
Ove Ericsson studied publications from the Norwegian Forestry Extension Service, and found that the books had a negative impact on the possibilities to achieve a better gender balance within the forestry sector (Ericsson, 1987).

\section{Actions concerning forest owners}

After establishing the organization, Women in Forestry immediately set up a working group to deal with the challenge of increasing the number of female forest owners, as well as making it more likely that the firstborn daughters of forest owners would decide to become the next forest owner. A number of initiatives and activities were organized. In particular, the organization;

- developed a booklet in the late 1980s, together with the Norwegian Forest Owners' Federation, giving ideas on how to organize forestry days for forest owner families;

- developed material and ran seminars for forest owners' firstborn daughters - together with Norges Bondekvinnelag - in the late 1980s and early 1990s;

- requested that names of both the man and woman be put into the forest owners' organizations register of members to make it more motivating for women to participate (invitations could be addressed personally to both names);

- requested that two votes be given to each forest holding that was member of a forest owners' organization, to motivate more women to take part in the organization's work.

Important cooperation with two national forest owners' organizations took place, particularly during the late 1980s and early 1990s. A forest owners’ district organization was identified (Sør Trøndelag Skogeierforening) and a pilot project was run 1990-1993. Later, focus was on how to increase the share of women within the board of directors of the forest owners' organizations. Lately, cooperation between Women in Forestry and district forest owners' associations has taken place, in particular with Allskog BA and Viken Skog BA.

To some extent, Women in Forestry has acted as an arena to build up competence and experience in organizational matters among female forest owners that later have become board members within the forest owners' organizations. On the other hand, women already in elected positions within forest owners' organizations often joined Women in Forestry and became key people within the organization.

\section{Actions concerning practical forestry}


for women to take part in practical forestry work. To achieve more women at the "Active Forestry" course programme, the General Assembly of Women in Forestry approved an action plan in 1991. This stated the need to promote the courses to women as a target group, offering courses for women only, having female teachers, offering children nursery care while holding courses, offering more flexibility and offering to lend out equipment needed to follow the courses.

An initiative from the organization resulted in a project at the Norwegian Forestry Extension Service, with economical support from the Ministry of Agriculture. Women in Forestry wanted the development to take place where it belonged, to make the implementation more efficient. The project is summarized in Chapter 1.10.1.

\section{Actions concerning secretaries}

From the very beginning, women employed as secretaries within the forestry sector were welcomed as members. In 1992, about 200 women were employed as secretaries or in other positions within the forestry sector, mainly within the Forestry Service or the forest owners organizations' (Sanness, 1992). Women in Forestry was concerned that the sector did not see the competence of these women. On the other hand, the organization wanted to develop their competence within forestry matters.

The organization took the initiative, and a project was carried out (1993-1997) together with the Ministry of Agriculture (project owner) and the Norwegian Forest Owners' Federation. Actions were tested in two counties (Akershus and Telemark). Competence building among secretaries was put on the agenda. While Women in Forestry expected the secretaries to build up their forestry competence, the secretaries mainly preferred to improve their existing competence concerning information technology, information and layout, among other things. There were some difficulties with project implementation within the private sector, as the project touched upon human resource policies; however, the project created new networks between employees in the private and public sector and processes have continued after the project finished (Women in Forestry, 1997).

\section{Network and internal focus}

During the first years of Women in Forestry, the members were offered, for instance, forestry courses and other courses to build and strengthen their self-confidence. This would help the members to handle their positions as female foresters more easily, within a sector still completely dominated by men.

Between 1990 and 2004, networking among the members was given high priority. The networking has 
included a number of seminars, meetings and events. Annually, seminars are offered at the national level. In addition, some regional seminars have taken place.

\section{International work}

After some years, Women in Forestry included international work on their agenda. In 1999, an International Symposium on Women in Forestry was held at Lillehammer. The symposium developed a platform that has resulted in further work on gender and forestry within IUFRO. 


\section{REFERENCES TO ENDNOTES FOR QUESTIONS 4 TO 7}

1. SOU 2004:39 (Official reports from Swedish government) Det går långsamt fram... - jämställdheten inom jord- och skogsbrukssektorn. (In the Common Agriculture Policy in EU 2002).

2. Jacobssen, H. 2002. Gender mainstreaming loner sig! Pilotprojekt om Gender Mainstreaming indenfor jord-og skogsbrugssektoren i nordisk ministerråd. Rapport 19.

3. Canada Employment Equity Act (1995).

4. Statistical Yearbook of Forestry. 2004. Official Statistics of Sweden, National Board of Forestry. Jönköping, Sweden.

5. Tomlin, P. \& Burth, K. Professional women foresters in the British forestry industry. Seminar proceedings, Women in forestry strategies to increase women's participation in the forestry sector in Europe and North America, 2-6 April 2001, Viseu, Portugal.

6. Statistical Canada n.d. www.statcan.ca.

7. Lidestav, G. 1998. Women as a nonindustrial private forest landowners in Sweden. Scandinavian Journal of Forest Research, Vol. 13, No. 1, pp. 66-73.

8. Seminar proceedings, Women in forestry strategies to increase women's participation in the forestry sector in Europe and North America, 2-6 April 2001, Viseu, Portugal.

9. Lidestav, G., Wästerlund, D. \& Engman, K. Self-conceptionand transfer of forest management tradition among female forest owners. Seminar proceedings, Symposium on Women and Forestry, 12-15 August 1999, Lillehammer, Norway.

10. Haugen, M. 2001. Rural women's employment opportunities and constraints. The Norwegian Case Center for Rural Research, Paper 8, NTNU, Norway.

11. Brandt, B., \& Haugen, M. 1997. Gender relations in forestry discourse. Paper 2 97. Center for Rural Research, NTNU, Norway.

12. Strupstad, L.M. 2001. Norwegian government policy is to encourage the active part of participation and employment of women. Seminar proceedings, Women in forestry strategies to increase women's participation in forestry in Europe and North America, 2-6 April 2001, Viseu, Portugal.

13. Women and Forestry. Proceedings of the Nordic-Baltic workshop, December 1998, Balsjö, Sweden.

14. Hoffman, V. 1998. Die Arbeitssituation der Waldarbeiterinnen in Deutschland. Eine sozialempiriche Untersuchung unter besonderer Berücksichtigung der Arbeitsbeanspruchung, Hamburg: Agrarwissenschaftliche Forschungergebnisse Band 14 
15. Wonneberger, E., 2002, Frauen in der Forstwirtschaft: Literaturanalyse und Hypothesen. Freiburg: WALD-Arbeitspapier Nr. 3. http://www.forst.uni-freiburg.de/fobawi/awi/wald/WALD-AP-3.pdf 16. Schmaltz S. 2003, Careers of Female Forest Engineers from the University for Applied Science and Arts Göttingen, Foreworknet Update, ILO Sectoral ActivitesDepartment - Joint FAO/ECE/ILO Commitee. http://www.ilo.org/public/english/dialogue/sector/newsletr/for wknet/update10.pdf

17. Teske, E. \& Beedle, B. 2001. Journey to the top - breaking through the canopy: Canadian experiences. The Forestry Chronicle, Vol.77, No. 5, pp. 846-853.

18. Reed, M.G. 2003. Marginality and gender at work in forestry communities of British Columbia, Canada. Journal of Rural Studies, Vol. 19, Iss 3, pp. 373-389.

19. Ehrenreich, D.L. 1996. Documenting progress. Journal of Forestry, Vol. 94, No. 11, pp. 8-12.

20. Carroll, F.O., Freemuth, J. \& Alm, L. 1996. Women Forest Rangers, Journal of Forestry, Vol. 94/1.

21. Palone, R.D. 2001. Women in forestry - Past and present. Pennsylvania Forests, Vol. 92/1,7-10.

22. See actual sections in this report. 